\title{
Birth and Development
}

of Parícutin Volcano

\section{Mexico}

By WILLIAM F. FOSHAG and JENARO GONZĀLEZ R.

GEOLOGIC INVESTIGATIONS IN THE PARÍCUTIN AREA, MEXICO

G E O L O G I C A L S U R VEY B U L L E T I N 965-D

Prepared in cooperation with the Comision Impulsora y Coordinadora de la Investigación Científica de México, under the auspices of the Interdepartmental Committee on Scientific and Cultural Cooperation, Department of State

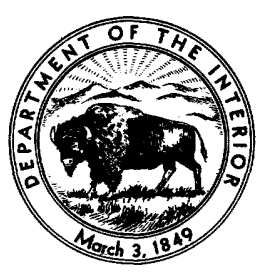




\section{UNITED STATES DEPARTMENT OF THE INTERIOR}

Douglas McKay, Secretary

\section{GEOLOGIGAL SURVEY}

W. E. Wrather, Director 


\section{CONTENTS}

Page

Abstract-1..

Previous investigations... 356

Fieldwork . . .

Acknowledgments. . .

Early lavas . . .

Early bombs...

Fumaroles_...

Volcanic sounds _.

Pre-Parícutin history

Mexican Volcanic Axis_.

Geologic setting

Local geography

Local history

Birth of Parícutin volcano

Earthquakes_........

Sources of information . .

Dionisio Pulido

Paula Pulido_..

Dolores Pulido .

Aurora Cuara .......... 378

Luis Ortíz Solorio

Anguiano and Martínez . . .

Celedonio Gutiérrez .............

Record of San Juan Parangaricutiro . . . . . .

Summary of accounts . . . .

Development of Parícutin volcano

Quitzocho period.

Early explosive phase

Heavy cineritic phase

Recurring flows . .

Quitzocho ridge $\ldots . . . . . .645$

Activity of July

Activity of August....... 422

Activity of September-October....

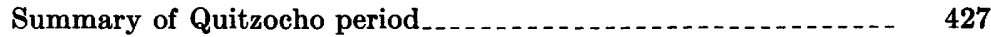

Sapichu period .

Sapichu vents.

Eruptive activity of Sapichu

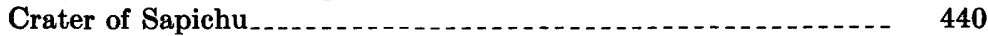

Crater of the main cone..... 442

Summary of Sapichu period....... 443

Taquí period

Taquí vents

Taquí lava flow . . .

Tremor zone

Crater activity 
Development of Parìcutin volcano-Continued

Taqui period-Continued $\quad$ Page

Luminous phenomena................. 455

The crater........... 456

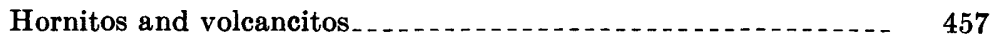

Parangaricutiro lava tongue

Destruction of San Juan Parangaricutiro . . . .

Later stage of Taqui flow ...

The crater on November 26, $1944 \ldots \ldots 4$

Rain erosion . .

Ahuán flow

The crater on January 22, $1945 \ldots \ldots$

The crater on May 27, 1945

Late stage of Taquí flow

Summary of Taquí period. .

General effects.... 479

Effect on life

Effect on agriculture

Effect on hydrology

Effect on microclimatology _. 483

Literature cited . .

Metric equivalents..... 486

Index . .

\section{ILLUSTRATIONS}

[Plates 12-15 are in pocket; plates 16-51 follow index]

Plate 12. Topographic map of the site of Parícutin volcano and vicinity, 9 years before the volcano's birth.

13. Topographic map of Parícutin volcano and vicinity, 3 years after the volcano's birth.

14. Geological reconnaissance map of the Tierra Caliente, Michoacán, México.

15. Map of Parícutin volcano, showing the lava flows of the first year.

16. Eruptive column of Parícutin volcano.

17. The new cone.

18. Eruptive column.

19. Horseshoe-shaped cone and Quitzocho lava flow.

20. Quitzocho lava flow.

21. Eruptive column and Quitzocho lava flow.

22. Heavy cineritic activity.

23. Eruptive column.

24. Breaks in the cone.

25. A. Partly restored broken cone.

$B$. Cineritic activity.

26. North flank chimney and heavy explosions with large bombs.

27. Lava bubbles bursting in crater.

28. Breaks in the cone.

29. Early and late stages of Quitzocho ridge growth.

30. Quitzocho ridge. 
Plate 31. Steaming ash in upper levels of cone and outbreak of Sapichu at base of main cone.

32. Sapichu.

33. Sapichu erupting.

34. Ash-covered hills and flows.

35. Taquí vents.

36. Mesa de los Hornitos.

37. A hornito and a volcancito.

38. Parícutin volcano.

39. Parícutin volcano from Cerro de Equijuata and Cerro de Jarátiro.

40. Parícutin volcano: interior of crater and long range view.

41. Parangaricutiro tongue and Parícutin volcano.

42. Eruptive column and block lava front.

43. Parangaricutiro tongue and Sapichu flow.

44. Parangaricutiro tongue: aerial and ground views.

45. Sapichu and Taquí flows.

46. Ahuán flow.

47. Typical erosion in ash.

48. Crater emissions.

49. Interior of the crater.

50. Taquí flows pouring over a ridge.

51. Interior of crater.

FIGURE 108. Index map of southern Mexico, showing the Mexican Volcanic Axis

109. Quitzocho-Cuiyúsuru valley and surrounding area before the
outbreak of Parícutin volcano

109. Quitzocho-Cuiyúsuru valley and surrounding area before the
outbreak of Parícutin volcano

110. Parícutin volcano at the time of its initial outbreak

112. Paricutin volcano on June 9,1943 , at $9 \mathrm{p}$. m. showing the cone complete except for a slight slump in the north crater rim

113. The cone on the morning of June 10, 1943, showing the slumped north side, the slumped block as a high sloping terrace, and lava flow

114. The cone on June 14, 1943, showing the break in the north slope of the cone

115. South crater in eruption on June 17,1943 , at 10:20 a. $\mathrm{m}_{\text {.-. }}$

116. Eruptions from the north and south vents on June 18. 1943, at 11:20 a. m .

117. Disappearance of the resistant plug on June 19, 1943, by disintegration by a vent at its base

118. Quitzocho ridge in early June, showing the smooth ashcovered Quitzocho and Mesa del Corral lava flows

119. Quitzocho ridge after the flow of June 9, 1943, showing the smooth ash raised by injection of lava below

120. Quitzocho ridge after the injection of lava in July-August 1943

121. Quitzocho ridge in late 1944. This is the final development of the ridge 
Figure 122. Parícutin volcano, showing its important stages of growth during the first year, February 20, 1943, to February 20, 1944

123. Parícutin volcano, showing the vents of $1943-44$

\section{TABLES}

TABLE 1. Analyses of early Parícutin lavas.

Page

2. Analyses of two early Parícutin bombs

361

3. Summary of first week of activity

362

391 


\title{
GEOLOGIC INVESTIGATIONS IN THE PARÍCUTIN AREA, MEXICO
}

\section{BIRTH AND DEVELOPMENT OF PARÍGUTIN VOLCANO}

\author{
By William F. Foshag ${ }^{1}$ and Jenaro González R.
}

\begin{abstract}
The Michoacán volcanic province is a portion of the Mexican Volcanic Axis, a zone of major volcanism that lies between parallels $19^{\circ}$ and $20^{\circ}$ and extends from the Pacific littoral to the gulf coast. The Michoacan province includes numerous basaltic and andesitic volcanic cones and flows of Pliocene, Pleistocene, and Recent age. The newest addition to these volcanic edifices broke forth from cultivated fields near the village of Parícutin on February 20, 1943, and has been named Parícutin volcano.

The first manifestations of new volcanic activity in the region were local seisms and subterranean noises that became apparent 2 weeks before the actual outbreak of volcanic eruption. These seisms increased in number and intensity until February 20, when the first volcanic outbreak occurred and the seisms ceased.

At about 4:30 p. m. of this day four eyewitnesses observed a mild explosion at a newly formed fissure in the fields of Llano de Cuiyúsuru, a farm lying 2 kilometers southeast of Parícutin village. A small eruptive column carrying dust and some hot stones arose from this new vent. For several hours the vent increased in size by the slumping of its walls, and the eruptive column grew in size. After about 8 hours of such activity the new volcano began to roar and to hurl out quantities of incandescent bombs with great force.

The new cone grew with great rapidity, reaching a height of 167 meters in 6 days of activity.

The volcanic activity of Parícutin during the initial period of $2 \frac{1}{2}$ years can be divided into three periods: (1) Quitzocho period, during which the activity was centered about the original Cuiyusuru vents and during which the volcano built its cone; (2) Sapichu period, with the principal activity taking place in the later Sapichu vents and the adventitious cone, Sapichu; and (3) Taquí period, when activity was largely connected with the Taqui and Ahuán vents.

The early part of the Quitzocho period was devoted to the building of the cone. Several recurrent surges of lava breached the growing cone. These breaches were rapidly repaired with each cessation of lava flow. The early ejectamenta was largely bombs and lapilli; after 1 month's activity the crater yielded largely cineritic material. During the latter part of the Quitzocho period, activity was more erratic and variable; a number of lava flows connected with the original vents broke from the flanks of the new cone and partially breached its walls. Flows spread over the fields to the north of the volcano, and explosive activity in the crater sometimes reached tremendous proportions.

During the Sapichu period activity shifted to a series of new vents at the northeast base of the cone. An adventitious cone, called Sapichu, formed; and a lava
\end{abstract}

\footnotetext{
${ }^{1}$ Published by permission of the Secretary of the Smithsonian Institution.
} 
flow, the Sapichu flow, covered the fields to the northeast. During the eruption of Sapichu the activity of the main cone was greatly reduced.

With cessation of activity at Sapichu, the main crater renewed its activity, and lava issued alternately from vents on the west and south base of the cone, the Taquí and Ahuán vents respectively. Lava flowed from one or the other vent almost continuously, but eruptive activity in the crater was erratic and variable and showed no apparent correlation with the emission of lava. When the lava flowed beneath a congealed crust, hornitos and volcancitos resulted.

After 3 years of activity the cone of Paricutin had reached a height of about 350 meters above the original vent. The altitude of the original vent, although never measured, was calculated from the elevation of the Paricutin-Uruapan road and an estimated slope of the terrain of about $5^{\circ}$ as 2,400 meters. Later, the increment of ash added to the cone was largely balanced by rainwash and slumping. The lava flows covered an area of about $18 \frac{1}{2}$ square kilometers and destroyed the villages of Parícutin and San Juan Parangaricutiro.

The lavas of Parícutin, during the first $2 \frac{1}{2}$ years of its life, were andesite-basalt and showed little variation during that period.

\section{INTRODUCTION}

\section{PREVIOUS INVESTIGATIONS}

Numerous accounts of the activity of Parícutin volcano have appeared, most of which impart the impression of the visitor during a very brief observation. A complete list has been compiled by Robert T. Hatt (1950). The first geological visitor to the scene was Ing. Ezequiel Ordónez $(1943,1945,1947)$, who has given us various detailed accounts of the volcano's activity. Other early accounts are given by Waitz (1943), De la O Carreño (1943), Robles Ramos (1943), Trask (1943), and others. A series of papers concerning Parícutin, published under the title El Parícutin, contains a description of the early activity (Flores and others, 1945). The events connected with the initial outbreak have been described by González and Foshag (1947), basing their narrative upon eyewitness accounts. White (1945) and Bullard (1947) have contributed details covering brief periods in the volcano's histery.

The area around Parícutin was mapped and described by Williams (1950), and the region lying between the Parícutin area, the Balsas River, and the Pacific coast was described and mapped by Gonzallez and Pérez-Siliceo (unpublished). Erosion studies have been made by Segerstrom (1950).

\section{FIRLDWORK}

At the time of the initial outbreak of Paricutin volcano, we were engaged in surveys relating to the mineral resources of Mexico. The duties incident to this task allowed us only occasional opportunity to visit the new volcano. It was not our original intention to compile a history of the volcano's activity, but it soon became apparent that our notes and observations contained data of unusual interest. We 


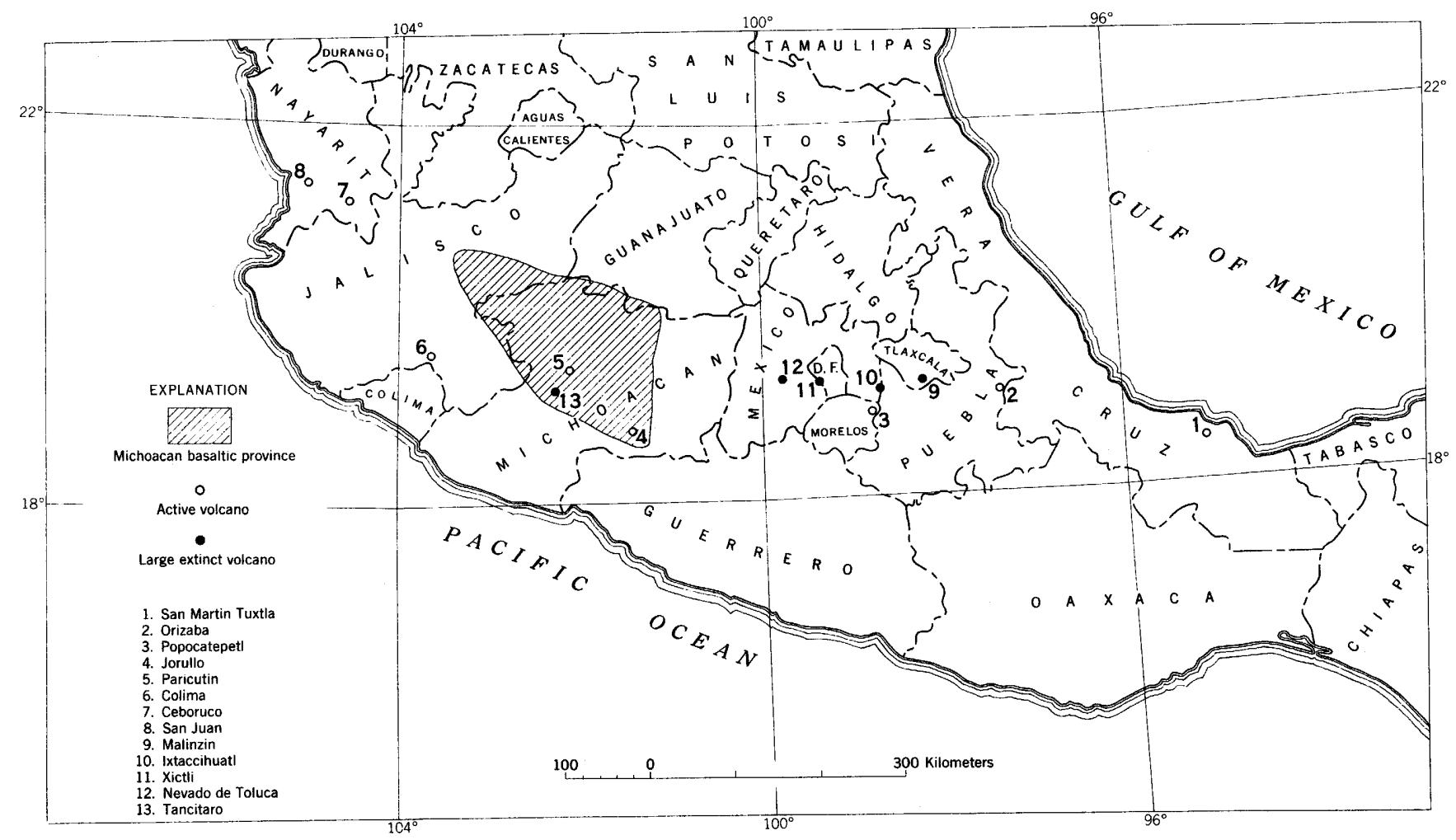

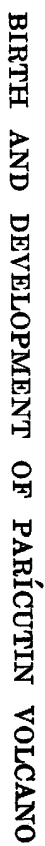

FIGURE 108.--Index map of southern Mexico, showing the Mexican Volcanic Axis. 
were particularly fortunate in being present during most of the important phases or at the time of critical changes in activity during the period covered in this report. Our observations have been supplemented, wherever necessary, by notes or information furnished by other visiting geologists. Proper acknowledgment for these data are included in the body of the narrative.

Our base was prineipally a small cabin we built on Cerro de Jarátiro ${ }^{2}$ a kilometer from the base of the new cone. Later we occupied a more commodious cabin built by the Instituto de Geología on the same hill. This point offered an excellent panoramic view, particularly since the early activity took place immediately in front of the hill. During the early phases of the volcano's activity, the area covered by lava was so small that one-half hour's walk took one to any sector of activity, or one could easily circle the entire area in a few hours of leisurely wandering. Consequently, few events escaped our notice.

The periods of observation, together with the names of the Mexican or American geologists present, other than W. F. Foshag, who was present on all dates noted, were as follows:

1943

Mar. 25-26.

May 21-26.

June 9-18

July 16-19

July 24-Aug. 3

Sept. 16-17.

Nov. 28-Dec. 7

\section{4}

Jan. 8-11

Feb. 10-13

Mar. 1-4.

Mar. 21-24

Apr. 5-6

Apr. 24-25

May 22-25.

June 29-July 1

July 6-8.

Aug. 14-18.

Sept. 16-18.

Nov. 24-Dec. 8
Ezequiel Ord6ñez, Donald White.

Frederick Pough.

Frederick Pough, G. A. Cooper, Adán PérezPeña.

Donald White.

Jenaro González R., Carl Fries, Jr.

James MacAllister, David Gallagher.

Adán Pérez-Peña.

Jenaro González R., Ezequiel Ord6ñez.

Jenaro González R., Eduardo Schmitter.

David Larrabee.

Jenaro González R.

Jenaro González R.

Jenaro González $\mathbf{R}$.

Ezequiel Ordoñez, Ward Smith, David

Gallagher.

Jenaro González R.

Jenaro González R.

Richard Fuller.

Edwin Eckel, James MacAllister, David Gallagher.

Ezequiel Ordónez, E. Zies, Howel Williams, F. G. Wells.

\footnotetext{
2 The authors prefer the spelling Arátiro, following Gilberti, Diccionaria de la lengua Tarasca, and the rules of Tarascan grammar formulated by Najera, Gramatica de la lengua Tarasca, but for the sake of consistency have agreed to follow the spelling used in previous chapters of this bulletin.
} 
Jan. 16-25 Jenaro González R., Howel Williams.

May 27-29 Carl Fries, Jr., J. V. N. Dorr 3d.

July $3-5$ Ezequiel Ord6́nez, William Wrather, Carl Fries, Jr.

July 24-31 Jenaro González R.

Aug. 6 Jenaro González R., Enrique Cantero.

In this report the authors have attempted to present a strictly factual account of the birth and development of Parícutin volcano and avoid any interpretive opinions that might break the true narrative of events.

\section{ACKNOWLEDGMENTS}

The observations contained in this report were made whenever time could be spared from a cooperative program of the Instituto de Geologia, the Comité Directivo para la Investigacion de los Recursos Minerales de México, the U. S. Geological Survey, and the Smithsonian Institution, under the auspices of the Interdepartmental Committee on Scientific and Cultural Cooperation, United States Department of State. This project had, for its primary object, the study of important mineral resources in Mexico. The program, of which these Parícutin volcano studies became an incidental part, was supervised by Ing. Teodoro Flores, Acting Director of the Instituto de Geología ; Ing. Ezequiel Ordóñez, member, Comité Directivo; Mr. John V. N. Dorr 3d, United States Geological Survey; and Dr. A. Wetmore, Smithsonian Institution. Realizing the unusual nature of this rare manifestation, they gave ready consent and encouragement to this project; and for these, and their many other contributions, we are deeply grateful.

The friendly villagers of San Juan Parangaricutiro and Parícutin gave us much assistance. We are particularly indebted to the late Sr. Felipe Cuara Amezcua, Presidente of the Municipio of San Juan Parangaricutiro, for many courtesies and valuable help, as well as for his solicitous attention to our well-being while at our isolated and exposed camp; and to our helpers, Celedonio Gutiérrez and Luis Aguilar, for faithful service under difficult and sometimes dangerous conditions. For their accounts of the initial outbreak of the volcano and the events of the first day we are greatly indebted to the following persons: Sr. Dionisio Pulido, his wife, Paula, and his brother, Dolores Pulido, of Parícutin (now of Caltzontzin), and Sra. Aurora Cuara, Srs. Luis Ortíz Solorio, Jesús Anguiano Espinosa and Jesús Martinez of San Juan Parangaricutiro (now of Ahuanicutiro), and Sr. José Caballero, now of Cherán.

Many visiting geologists have furnished us with information concerning the activity of the volcano during their stay. We are par- 
ticularly indebted to Mr. Donald White, of the United States Geological Survey, for copies of his notes for the periods July 16-19 and October 1-5, 1943, and February 4-6, 1944, and to Sr. Adán PérezPeña for copies of his notes for the period June 9-19, 1943. Sr. Pérez-Peña also mapped, at our request, the lavas of 1943.

One of the important tasks we set to do was the collecting of significant photographs depicting the development of the volcano. Proper credit is given for each contribution of photographs used in this report. Unless otherwise noted, photographs are by W. F. Foshag. We are particularly grateful to Dr. O. O. Fisher for his efforts in this project. Many of the early photographs were assembled through his efforts. We are likewise indebted to Dr. Frederick H. Pough, of the American Museum of Natural History, for copies of striking color motion pictures of the activity of the volcano.

The keen interest of Dr. O. O. Fisher in the project again manifested inself in funds for the rebuilding of the cabin observatory on Cerro de Jarátiro when lava flows were about to destroy it, for supplies for our comfort, and for the use of his private airplane for observations about the volcano. We are likewise indebted to Col. Ray Baker for the use of his plane for similar purposes.

The drawings for figures 111-123 included in this report are the work of William Crockett, artist, Department of Geology, United States National Museum.

Funds for the chemical analyses of early lavas and bombs were appropriated by the United States Committee for the Study of Paricutin volcano, from a grant of the Geological Society of America.

\section{EARIY LAVAS}

The lavas that flowed from the Parícutin vents during its early formative period were basaltic in nature and aa or block lava in character. Samples of all the flows during this period were collected, and the analysis of four appears in table 1. These four samples represent (1) the first lava, the Quitzocho flow, March 5, 1943; (2) the Sapichu lava, which issued during the period October-November 1943, collected at its front near the San Juan ParangaricutiroUruapan road on April 24, 1944; (3) the Ahuán flow, which opened in mid-November 1944, collected at the lava vent on December 2, 1944; and (4) the Taquí flow, which began on January 8, 1943, sample collected from active lava flow at the base of Cerro de Jarátiro on July $27,1945$.

A very slight progression toward a more siliceous lava is suggested by these analyses of the early lavas.

The lavas vary from dark gray to black, sometimes streaked with raisin brown where the effects of steam have oxidized the iron. 
TABLe 1.-Analyses of early Paricutin lavas [Analyses 1-3 by Erma Chadbourn; 4 by W. F. Foshag]

\begin{tabular}{|c|c|c|c|c|}
\hline & Quitzocho & Sapichu & Ahuán & Taqui \\
\hline $\mathrm{SiO}_{2} \ldots$ & 54. 88 & 55. 51 & 55. 59 & 56. 62 \\
\hline $\mathrm{Al}_{2} \mathrm{O}_{3} \ldots$ & 18. 38 & 18. 19 & 17. 72 & 17. 54 \\
\hline $\mathrm{Fe}_{2} \mathrm{O}_{3} \ldots$ & 1. 31 & 1. 63 & 1. 33 & 1. 86 \\
\hline $\mathrm{FeO}$ & 5. 97 & 5. 38 & 5. 99 & 5. 47 \\
\hline $\mathrm{MgO}_{\ldots} \ldots$ & 5. 57 & 5. 31 & 5. 60 & 5. 31 \\
\hline $\mathrm{CaO}_{\ldots} \ldots$ & 7. 40 & 7. 19 & 6. 99 & 7. 13 \\
\hline $\mathrm{Na}_{2} \mathrm{O}_{\ldots}$ & 3. 88 & 3. 92 & 4. 00 & 3. 89 \\
\hline $\mathrm{K}_{2} \mathrm{O}_{\ldots} \ldots$ & .86 & 1. 10 & 1. 13 & 1. 21 \\
\hline $\mathrm{H}_{2} \mathrm{O}+\ldots$ & .13 & .08 & .03 & 12 \\
\hline $\mathrm{H}_{2} \mathrm{O}-$ & .05 & .01 & .04 & .12 \\
\hline $\mathrm{TiO}_{2} \ldots$ & .95 & .97 & 1. 05 & 1. 00 \\
\hline $\mathrm{P}_{2} \mathrm{O}_{5} \ldots$ & .29 & .31 & .36 & $\ldots$. \\
\hline $\mathrm{MnO}$ & .13 & .12 & .13 & .12 \\
\hline Total & 99. 80 & 99. 72 & 99.96 & 100. 17 \\
\hline
\end{tabular}

All the lavas of Parícutin volcano are fine grained, almost aphanitic rocks, with sparse scattered phenocrysts of olivine and, rarely, hypersthene. Under the microscope they show the usual basaltic texture. The feldspar of the groundmass is in the usual lathlike, or tabular, form; the pyroxene forms an intersertal aggregate of stumpy prisms. Scattered euhedral to subhedral olivine phenocrysts are always present, and there is a scattering of small magnetite or picotite octahedra. Sometimes small intersertal areas of dark-brown glass remain. The plagioclase feldspar shows little compositional zoning, but the composition varies with crystal size. Large crystals have an average composition of $A b_{49}$ changing to $A b_{53}$ in small crystals and $A b_{70}$ in very small crystals.

\section{EARLY BOMBS}

Two ejected bombs recovered by Anguiano and Martínez during the initial outbreak at 10 p. m., February 20, 1943, were preserved by the parish priest, Sr. José Caballero, who generously presented them to us for study. The analyses in the following table show that these early ejected fragments are not bombs of Parícutin lava but probably represent the old lavas underlying the Quitzocho-Cuiyúsuru valley. The topography suggests that these flows were derived from the ancient Cerro de Camiro cone.

\section{FUMAROLES}

Fumaroles were abundant in the early lava flows, particularly in the Quitzocho flow, and will be referred to in this report. They were 
TABLE 2.-Analyses of two early Paricutin bombs

[Bombs 1 and 2, ejected from Parícutin volcano, February 20, 1943. Erma Chadbourn, analyst]

\begin{tabular}{|c|c|c|}
\hline & 1 & 2 \\
\hline $\mathrm{SiO}_{2}$ & 51.00 & 53. 14 \\
\hline $\mathrm{Al}_{2} \mathrm{O}_{3--}$ & 17.54 & 18. 26 \\
\hline $\mathrm{Fe}_{2} \mathrm{O}_{3 \ldots}$ & 2. 21 & 2. 03 \\
\hline $\mathrm{FeO}_{\ldots} \ldots$ & 5. 90 & 5. 27 \\
\hline $\mathrm{MgO}_{\ldots} \ldots \ldots$ & 8. 35 & 7.25 \\
\hline $\mathrm{CaO}_{\ldots}$ & 8. 89 & 7. 93 \\
\hline $\mathrm{Na}_{2} \mathrm{O}$ & 3. 15 & 3. 68 \\
\hline $\mathrm{K}_{2} \mathrm{O}_{\ldots}$ & .72 & .73 \\
\hline $\mathrm{H}_{2} \mathrm{O}+\ldots$ & .46 & .08 \\
\hline $\mathrm{H}_{2} \mathrm{O}-$ & .14 & .03 \\
\hline (1) & 1.05 & .92 \\
\hline-1$)^{-1}$ & .23 & .22 \\
\hline $\mathrm{MnO}_{2}$ & .14 & .13 \\
\hline Total_. & 99. 78 & 99.67 \\
\hline
\end{tabular}

numerous about the periphery of the flow but rare within the flow itself. In the latter case they appeared to be connected with serious disturbances in the flow, as in large pressure hummocks or where the flow had moved over abrupt terrain (pl. 45A). The fumaroles in the Quitzocho flow persisted for more than a year, until covered by later flows, and showed no apparent diminution or change in character. Measurements on the fumaroles of the Quitzocho flow showed temperatures ranging from $105^{\circ}$ to $430^{\circ} \mathrm{C}$. It was found that the emanations of fumaroles ranging from temperatures of $100^{\circ} \mathrm{C}$ to $250^{\circ} \mathrm{C}$ were acid in reaction and yielded a noxious odor of hydrochloric acid, while the higher temperature fumaroles, from $250^{\circ} \mathrm{C}$ to $430^{\circ} \mathrm{C}$ yielded an alkaline emanation and a burnt or distinctly ammoniacal odor. The lower temperature, acid fumaroles were associated with altered, brick-red lava and were surrounded by aureoles of colored salts. The higher temperature alkaline fumaroles showed only minor rock alterations.

Field tests of the fumarolic emanations revealed, in addition to abundant steam, the presence of hydrochloric acid, ammonium chloride, and minor amounts of sulfur trioxide, sulfur dioxide, hydrogen sulfide, and carbon dioxide. Lead and free chlorine were very rare. Condensable solids, collected in tubes introduced in the fumaroles, showed a surprising simplicity of composition consisting of ammonium chloride with small amounts of sodium and potassium chlorides and minute quantities of fluorides (Foshag and Henderson, 1946). 
The reaction of these emanations with the wall rock of the fumaroles, or with overlying ash, yielded secondary chlorides of iron and ammonium, calcium, magnesium, and others; an oxychloride of aluminum, a hydrous basic chloride of magnesium, and similar salts. Sulfur was a very rare and inconspicuous deposit.

In addition to the fumaroles, there were vents that yielded only steam, presumably where hot lava was in contact with moist ground or a similar source of water. Buried stream channels, as of Arroyo de Nureto, localized a line of steam emanations during the rainy season. Trees engulfed in the lava yielded distillation products and resembled fumaroles in appearance. The three types of emanations could, however, be readily distinguished. The vapors of steam were pure white; the emanations from the fumaroles were bluish, owing to their content of finely divided particles of condensed solids; and the distillation from organic matter, such as trees, had a brownish tint.

High-temperature fumaroles, $1,100^{\circ} \mathrm{C}$ to $1,200^{\circ} \mathrm{C}$ were abundantly associated with the hornitos above the Taqui flow. The gaseous emanations, with a strong odor of hydrochloric acid, were frequently too noxious to permit entry into the hornito area. At times, brightyellow and orange fumarolic deposits colored large areas of the lava crust. These fumaroles were usually accompanied by burning gases, and their orifices were lined with a fused rock coating. Hematite, magnetite, apthitalite, and thenardite formed in the vents. Later, aluminum and other chlorides formed by the interaction of the gases and the lavas.

Frequently the rains showed a mild acid reaction and contained soluble salts derived from the eruptive column of the volcano.

\section{VOLCANIC SOUNDS}

Reference will be made frequently in this report to the various sounds heard during the eruptions of Parícutin volcano. In the course of our observations we were concerned with the origin and interpretation of these sounds, particularly those emanating from inaccessible places, as the crater in full operation. In some cases we were definitely able to determine the cause of the sound, and in others to gain a reasonably good indication of their origin.

Wilcox (1947) has listed various sounds common at Parícutin. He distinguishes 11 distinct types, without, however, indicating their origins. Some of these 11 categories may have a similar origin but vary in intensity or duration.

One of the common sounds is usually compared by everyone who hears it to the beating of a heavy surf upon a shore. It is associated with the bursts of bombs from the crater, the successive blasts yielding a pulsating or surflike roll. This sound is undoubtedly due to the 
combined swish of falling bombs. A softer surging, like the sough of the wind in the pine trees, probably results from the fall of lapilli or the smaller bombs. Following this surflike noise, one can frequently distinguish the slap of the bombs falling on the slopes of the cone.

Sounds from the interior of the crater are muffled by the crater walls. These sounds originate, chiefly, in the eruptive vents of the crater but are modified by the shape and size of the vent and the intensity and character or period of the emission. Several visits to the rim of the crater during moderate eruption have given us some insight in the interpretation of these sounds. A deep throaty roar results from the rush of vapors from a small vent; a low growl from the intermittent emission of a similar vent. A vapor column from a crater vent produces a thunderlike roll, which may be a grating roar when the velocity is high.

Other sounds are definitely connected with lava vents. Rhythmic sounds like a locomotive are noticeable during periods of lava emission and presumably connected with the rising lava column. We have noticed these sounds only about small, newly opened eruptive orifices and not with long established lava vents.

A sibilant sound, which close by becomes a strong and continuous hiss, is produced by the forced emission of vapors from the small vents of the hornitos that form upon the lava crust. This sound is sometimes perceptible from several miles away. A sharp whistle is sometimes produced by the small but rapid whirlwinds that are made by the escape of gases from incandescent and flowing lava.

Sharp pistollike reports accompany the short, lightning discharge in the rising eruptive column. Frequently these lightning discharges are hidden in the eruptive column, or are not visible in the light of day. The lightning discharge may appear as a point discharge, with a resulting sharp crack or report. Even the largest bolts are short discharges.

The sounds were frequently suggestive when certain phases of activity were hidden from view.

\section{PRE-PARÍCUTIN HISTORY}

\section{MEXICAN VOLCANIC AXIS}

The Mexican Volcanic Axis forms a velt about 900 kilometers long and 70 to 100 kilometers wide, extending from San Martín Tuxtla on the Gulf of Mexico to Colima and Tepic on the Pacific coast. It lies between lat $18^{\circ}$ and $19^{\circ} \mathrm{N}$., except in the extreme west, where it broadens out to extend as far north as the $22 \mathrm{~d}$ degree of latitude. It is transverse to the other volcanic axes of North America, the coast range volcanoes of California and the Volcanic Axis of Central America, both of which parallel closely the Pacific coast of the conti- 
nent. This zone includes the active volcanoes (from east to west) San Martín Tuxtla (active in 1793), Orizaba (1687), Popocatepetl (1920-24), Jorullo (1759-?), Colima (1913), Ceboruco (1870-75), and San Juan (1859-?), as well as the prominent but mactive or extinct volcanoes, Nevada de Toluca (4,565 meters), Malintzin (4,115 meters), Ajusco (3,950 meters), Tancítaro (3,845 meters), and innumerable smaller cones and other volcanic edifices (fig. 108).

This volcanic zone occupies a critical position in the epeirogenic structure of North America, separating, as it does, the high central plateau (Mesa Central) of Mexico from the rugged and deeply dissected terrain of Meso-America and hiding beneath its cover of late volcanic products the transition between these two diverse geologic provinces. This critical position of the Volcanic Axis has already been emphasized by Pedro Sánchez (1935). In his opinion this axis fixes the southern limits of North America. That portion of Mexico lying to the south has the characteristics of Central America and is, therefore, to be included in Meso-America.

The area lying north of the Volcanic Axis, the Mesa Central, is a high plateau with a general altitude between 2,000 and 2,500 meters. Its rocks consist principally of limestone of Mesozoic age, covered in many places by volcanic flows and deposits of middle or late Tertiary age. The principal structural trends in this province are northwest. The area lying to the south of the Volcanic Axis, the Sierra Madre del Sur, in comparison, is extremely rugged, complex in geologic structure, and deeply eroded. Crystalline rocks and many intrusions characterize the province, while limestone of Mesozoic age and Tertiary volcanic rocks are restricted largely to remnants upon the higher eminences.

In addition to these topographic and geologic differences, the two provinces show striking seismic contrasts; the Mesa Central is an area of stability, the Sierra Madre del Sur one of strong and frequent earthquakes.

There are marked gravitational differences, too, between the two provinces. North of the Volcanic Axis the gravitational anomalies are small, increasing in negative value as one approaches the axis itself, where the highest anomalies are recorded. Continuing south the negative anomaly drops rapidly in value until it reaches zero (Sanchez, 1935; Carreño, 1943).

The Volcanic Axis is a Pliocene to Recent superposition of volcanic edifices upon the transition zone of the Mesa Central and the Sierra Madre del Sur. The earlier lavas are largely andesitic in character, but there are sporadic occurrences of rhyolitic effusions. Later lavas are andesite-basaltic to balsaltic in composition. The earlier cones are huge edifices (Orizaba, Ixtaccihuatl, Tancítaro), while the late $3386690-55-2$ 
ones make up for their comparatively small size by their abundance. In most portions of the Volcanic Axis, the volcanic products completely mask the underlying formations.

It is worthy of note that along the eastern plateau front of Mexico, a scattering of recent volcanic cones are similarly distributed. Along the foot of the eastern plateau scarp, within the small folded valleys of the plateau front, and along the eastern plateau summit, small recent basalt cones and flows can be seen; while within the high central plateau, recent basaltic cones are rare. Most striking of these interior basaltic emissions are the extensive rugged flows of the Breñal, in Durango.

\section{GEOLOGIC SETTING}

The Michoacán volcanic province occupies that portion of the Mexican Volcanic Axis lying between the Sierra de Ozumatlán and Lago de Chapala. Here the transition zone between the Mesa Central and the Sierra Madre del Sur is relatively narrow and sharp but completely mantled by the volcanic cover of the Volcanic Axis. The plateau, which at Uruapan has an altitude of 1,600 meters, drops abruptly to the Río de Tepalcatepec (200 meters), at the foot of the plateau front. Late volcanic edifices and deposits completely cover the plateau front; volcanic agglomerate deposits and a few scattered ash cones occupy the lower valley slopes as far as the Rio de Tepalcatepec. Beyond the Río de Tepalcatepec, no more late volcanic cones or deposits are to be found, and middle Tertiary effusive rocks are seen as scattered remnants of rhyolite flows and tuffs that crown some of the higher eminences, particularly in the low country lying south of La Huacana, along the lower Río de Tepalcatepec and Río de Las Balsas. Since middle Tertiary time, the region south of the Río de Tepalcatepec has seen no volcanic activity; while immediately to the north, vulcanism has been intense in late Pliocene (Cerros de Tancítaro) and particularly in Pleistocene and Recent times. The relationship of the Volcanic Axis to the Sierra Madre del Sur province is nowhere more clearly defined than in the zone immediately south of the Parícutin area.

From our knowledge of the geology of the area (pl. 14) between the Río de Tepalcatepec and Río de Las Balsas and the Pacific Ocean, the Tierra Caliente, we may divide the area into two distinct parts. Between the Río de Tepalcatepec and the Pacific Ocean, the rocks are largely of sedimentary nature, principally black fissile nonfossiliferous slates which from their similarity to slates in the State of México and other areas, are presumed to be of Jurassic age. More advanced metamorphism has converted these slates into phyllites in many places. Red sandstone and conglomerate, exposed along 
the Pacific coast and as minor patches inland apparently lie below these slates and may be of Triassic age Above the slates and crowning a few of the highest ridges is limestone similar to the Cretaceous limestone in other Mexican occurrences.

Large masses of diorite and smaller ones of diorite, monzonite, granite, and adamellite are intrusive in these sedimentary formations. Residual masses of rhyolite, rhyolite tuff, or andesite cap a few of the higher eminences in the northern part of the area.

The region lying between the plateau front and the Río de Las Balsas has a rather different lithological character. The oldest formation exposed is a melaphyric basalt composed of aphanitic, amygdaloidal, and porphyritic types. The amygdaloidal form frequently carries secondary epidote, calcite, and quartz in cavities. The porphyritic type is widespread and striking in appearance, with phenocrysts of labradorite reaching a centimeter in size in an aphanitic groundmass.

Numerous large and small dikes and large masses of diorite are intrusive into these basalts; in some places, as at Inguarán and Oropeo, they are associated with copper ore deposits.

Rhyolite flows and tuffs cap the higher peaks and mesas of both melaphyric basalt and the intrusive dioritic rocks. These rhyolites are similar to those of the Mesa Central, where they are much more widespread and rest upon sedimentary formations of Mesozoic age or upon andesites of middle Tertiary age.

Although the rocks underlying the Volcanic Axis in the Michoacán area are completely covered by late lavas, some knowledge of the underlying geology can be gained by a study of the xenolithic bombs found in the old ash cones and the inclusions in the lavas. Every volcanic edifice of the region yields some of these inclusions; in some they are abundant. Parícutin volcano has yielded xenoliths of quartz monzonite, granite, and rhyolite. The limited collection of these xenoliths now at hand, made over a wide area of the Michoacán province, indicates that the sublava basement has its closest affinities with the area lying between the Volcanic Axis and the Río de Las Balsas and that it is principally composed of intrusive granitic and dioritic rocks with some rhyolite. As yet no melaphyric basalt has been recognized among the xenolithic materials, nor limestone, slate, phyllite, nor crystalline metamorphic rocks. This suggests that the rocks of the Balsas-Tepalcatepec area, rather than the rocks of the Pacific littoral, or those of the Mesa Central, underlie the Parícutin area.

One of the important elements of the Mexican Volcanic Axis is the Michoacán volcanic province, extending from the Sierra of Ozumatlán in central Michoacán to the western shores of Lago de Chapala, in 
Jalisco. To the north, this province passes gradually into the lower Bajío of Guanajuato and to the south terminates abruptly at the foot of the plateau front and the beginning of the Tierra Caliente.

The Sierra de Ozumatlán, the eastern border of the Michoacán basaltic province, is a rugged mountain mass of dissected older andesitic lavas, which show few, if any, late Tertiary or Recent volcanic emissions. To the east of the Sierra de Ozumatlan, in the valley of the Río Taximaroa, of eastern Michoacán, volcanic cones and flows again become conspicuous but in much fewer numbers and more scattered than in western Michoacán.

To the north, the Michoacán province passes gradually into a province of earlier rhyolitic rocks of Guanajuato and southeastern Jalisco. Late volcanic edifices become progressively fewer until the Río Lerma is reached, beyond which few basaltic cones or flows are noted, the topography being characterized by elongated ridges or mesas of rhyolitic flows and tuffs. The last striking manifestation of late basaltic vulcanism in this direction is the nest of well-preserved cones in the valley of Río de Santiago.

The western limits of the province, like the northern, are not easy to define, because the province again passes gradually into a coastal province of rocks of Mesozoic and middle Tertiary age, where the later Tertiary volcanic manifestations are dominated by the emissions of the large Colima and Ceboruco volcanoes. The southern limit, on the other hand, is strikingly abrupt, terminating at the foot of the plateau front. On the plateau slope the rocks are exclusively late Tertiary to Recent basalts or related lavas. From the foot of the plateau front through the Tierra Caliente, late volcanic formations are absent. This abrupt change is best shown along the plateau slope between Uruapan and the Río de Tepalcatepec, where many well-defined cones are evident; while beyond the Río de Tepalcatepec, no late Tertiary or Recent volcanic edifices are found.

Studies by Williams (1950) in the Uruapan region indicate that there are three general phases of Tertiary vulcanisms in the Michoacán volcanic province (excluding an early volcanic sequence of melaphyric lavas that probably underlies part of the province). An early phase represented by the Zumpinito lavas is probably equivalent to the lavas of the Sierra de Ozumatlan that limit the basaltic province on the east and perhaps, also, to the lavas that cap the higher eminences south of the Río de Tepalcatepec. A second phase includes the emission of lavas that formed the high mass of Cerros de Tancítaro and other coeval cones. A more conspicuous phase, however, is that of the numerous later and recent cones and flows, of which Jorullo and Parícutin are the newest manifestations. 
The eruptive rocks of this last phase range from andesite through andesite-basalt and basalt to olivine-basalt. The older cones, higher in elevation and more eroded than the later cones, are chiefly andesitic. The late Pleistocene and Recent cones retain their original features but little altered and are principally basaltic.

No alignment or regular pattern of distribution of these cones is apparent to indicate a control by prominent fissures. Nor is there any readily apparent evidence that the late cones, once they had ceased activity, were the loci of later renewed outbursts. Any new activity established itself in a new locus, such as Jorullo or Parícutin, independent of any apparent previous structure.

\section{LOCAL GEOGRAPHY}

Before the advent of Paricutin volcano, the principal town of the region was San Juan Parangaricutiro. As is the custom in naming towns in southern Mexico, the designations frequently combine the Spanish name of the town (San Juan) with its indigenous name (Parangaricutiro). San Juan Parangaricutiro was also the cabecera, or governmental center, of the municipio, a political subdivision corresponding somewhat to an American township. Its inhabitants were largely of mixed Spanish-indigenous blood. Included within the municipio of Parangaricutiro are the villages of Angahuan, Parícutin, Zirosto, and Zacán. San Juan Parangaricutiro was also the commercial center of the region. It had a population of about 4,000 people. The beautiful 18th century church of the town housed the famous Señor de los Milagros, the figure of a saint venerated throughout the region. An annual celebration and fair was held in honor of this saint on each 14th day of September.

Two kilometers south of San Juan Parangaricutiro was the village of Parícutin, consisting of about 150 Tarascan families. Parícutin was famous for its fruit, particularly pears. West of San Juan Parangaricutiro is Zirosto, also a Tarascan village. About 2 kilometers northeast of San Juan Parangaricutiro is the village of Angahuan, a pure Tarascan town, and now, since the destruction of San Juan Parangaricutiro, the largest town of the municipio. A beautiful ancient Franciscan chapel faces the main plaza of the town. Zacán is a Tarascan village to the north of San Juan Parangaricutiro and at a higher elevation.

About these villages lie the cultivated fields of the villages, devoted chiefly to the growing of corn, except on the higher elevations where wheat prospered. Surrounding the fields are wooded old volcanic cones or ridges formed by old lava flows. Rich cornfields occupy the craters of many of these old volcanoes, and oak and pine forests, which are a source of timber and turpentine, cover the volcanic slopes. 
Three kilometers south of San Juan Parangaricutiro and 2 kilometers southeast of Parícutin lay a small valley, bordered on almost all sides by pine-clad volcanic hills. On the north was Cerro de Jarátiro, with three ancient but well-preserved craters; to the southeast is the conical wooded mass of the extinct volcano Cerro Prieto, with several alluvium-filed craters; to the south Cerro de Camiro, Cerro del Cebo, and the lower slopes of Cerros de Tancítaro, with its incumbent later cones; and to the west the steep front of the volcanic Mesa de Cocjarao and the eroded cone of Cerro de Canicjuata.

Among the parcels of land within this valley were two adjoining ones: Llano de Quitzocho and Llano de Cuiyúsuru ${ }^{3}$ (fig. 109), both belonging to Parícutin. They were separated by a stone wall and were considered valuable for their forest lands and cultivated fields. Barbarino Gutiérrez owned Quitzocho, and Dionisio Pulido owned Cuiyúsuru. A large rock, called Piedra del Sol because it caught the early morning rays of the sun, was a nearby boundary marker. Lava flows now completely fill this small valley, and it is difficult for one who did not know it before the lavas came to picture its original charm. It had a diameter from north to south of $2 \frac{1}{4}$ kilometers and from east to west, $1 \frac{1}{2}$ kilometers. The south end of the valley was occupied by several old lava flows, whose steep fronts formed wooded scarps and crests bore cultivated fields. From these volcanic terraces the ground sloped gently north toward Cerro de Jarátiro. The lowest point in the valley at the foot of Cerro de Jarátiro had an altitude (by aneroid)

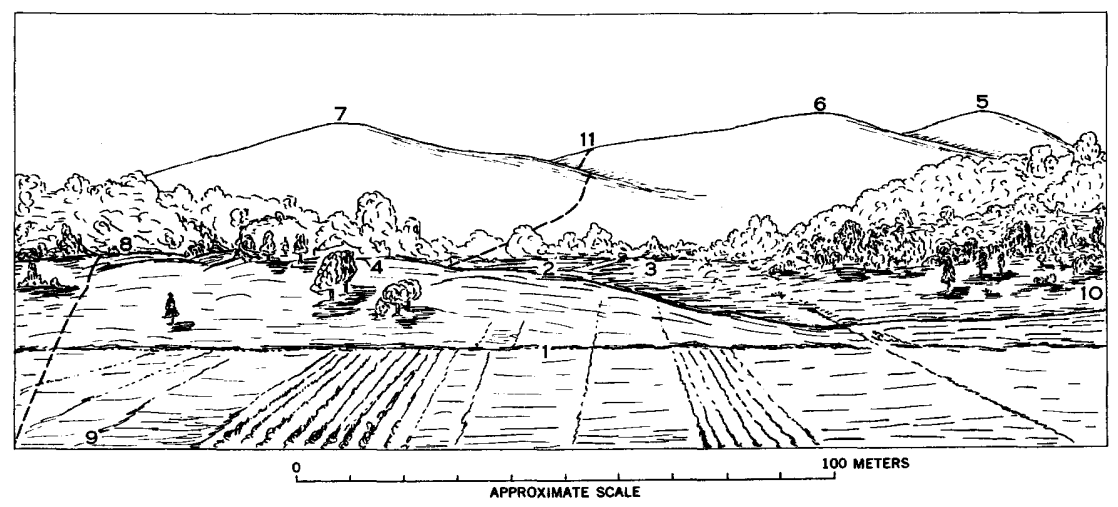

Figure 109.-Quitzocho-Cuiyúsuru valley and surrounding area before the outbreak of Parícutin volcano as reconstructed from observations of early volcanism. 1, Quitzocho; 2, Cuiyúsuru; 3, Pastoriu; 4, Uricua Llostiro; 5, Tancítaro; 6, Cebo; 7, Camiro; 8, Piedra del Sol; 9, Sherecuaro; 10, Parícutin Arroyo; 11, Parangaricutiro-Paricutin boundary-passes in front of foreground and follows ridge along Cebo and Tancitaro. Road from Camiro hill, San Nicolas, and Teruto follows left boundary of sketch, Uruapan-Paricutin road follows front boundary.

\footnotetext{
${ }^{3}$ The authors of this chapter prefer the spelling Cuiyutzuru, as used in the official archives of the municipio of San Juan Parangaricutiro, but for the sake of consistency have agreed to follow the spelling used in previous chapters of this bulletin.
} 
of 2,375 meters. To the northeast, the valley merged with the cultivated fields through Jarumagagitiro, Sherecuaro, La Lagunita toward Tipacuaro and other parcels of land lying at the eastern foot of Cerro de Equijuata and Cerro de Capatzun.

The valley was drained by Parícutin Arroyo, whose principal headwaters were between the old volcanic cone of Cerro de Canicjuata and the high lava terrace of the Mesa de Cocjarao. Near its headwaters was the spring that supplied Parícutin village with its potable water. Parícutin Arroyo carried a flow of water only during the rainy season. A small tributary, usually dry, passed through the cultivated lands of Cuiyúsuru. Parícutin Arroyo left the valley through a narrow gap between the lower slopes of Cerro de Canicjuata and Cerro de Jarátiro near the parcel Titizu, where it was a steep-walled gully about 4 meters deep. It then passed the eastern edge of Parícutin village, turned west, and joined the Arroyo Principal of San Juan Parangaricutiro in the fields of Huirambosta.

At the eastern foot of Cerro de Jarátiro was the parcel of land La Lagunita, a small depressed area sometimes occupied by an ephemera] pond. Drainage to the northeast was not well defined; a few shallow arroyos joined the Arroyo Principal above San Juan Parangaricutiro, along the San Juan Parangaricutiro-Uruapan road.

Except for trees along Paricutin Arroyo and its tributaries and a few small copses of pines, the valley land was cultivated. No permanent dwellings were in the valley, but stone walls or fences separated one parcel of land from another. The little used Uruapan-Parícutin road followed the foot of Cerro de Jarátiro, and wood roads and horse trails passed through the forest lands. The road to Camiro, Teruto, San Nicolás, and other points skirted the valley on the east.

One of the minor features of the valley that attracted some attention was a small hole in the farm, Cuiyúsuru. Dionisio Pulido, owner of the farm, described it as having a diameter of 5 meters and a depth of $1 \frac{1}{2}$ meters. Sra. Severiana Murillo, now an old lady, recalled how, as a child more than 50 years ago, she played about this pit. She remembers it well because her father warned her to avoid the spot, because, he said, it was the entrance to an old Spanish mine (although no mining activity has been recorded in the region) and because one frequently heard subterranean noises near the hole, as if made by falling rocks. The children amused themselves about this hole because it emitted a pleasant warmth, and they probed it with sticks without touching a bottom.

Robles Ramos (1943) quotes Vicente Mediano as relating that he noted a depression that had formed in the field as early as the month of August 1942, and that a kind of mist was emitted from it during a period of rains, but he attached little importance to it. Dionisio 
Pulido sometimes referred to this pit as a resumidero, a hole in a closed basin through which storm waters escaped during the rainy season.

As is usual in these regions of Michoacán, the tillable lands are privately owned, but the forest lands belong, in large part, to the villages. The forests, being sources of lumber and turpentine, are an important asset to the community. The owners of the parcelas, or farms, live in the villages, and the workers travel each day with their oxen and tools from the village to their fields or to the forest, returning in the evening to their homes.

\section{LOCAL HISTORY}

The tragedy of the people of the region about Parícutin began, according to their beliefs, many years ago. Then San Juan Parangaricutiro, the town which became the important center of the area, the greatest in influence, and the governing head of the municipio, bought lands from other villages to add to its municipal domain. Parícutin, too, sold lands to San Juan Parangaricutiro; but San Juan Parangaricutiro, according to those of Parícutin, took to itself more than it had purchased. Parícutin offered to settle for " 4 cargas más 2 cuartillos de pesos," in accordance with an ancient manner of payment; but no accord or compromise could be agreed upon. This situation led to constant and acrimonious disputes, until there developed such a deep feeling of enmity that those of one village hardly dared pass upon the lands of the other. This animosity led to frequent altercations on the disputed lands, during one of which Nicolás Toral, of Parícutin, lost his life, almost on the spot where the new volcano was to break forth.

The ecclesiastical authorities of the parish, desiring that the dispute should cease and the two villages live in harmony, placed upon Peña del Horno, a huge rock high on the flanks of Cerros de Tancítaro, a large wooden cross with an inscribed plaque of silver, facing the part of the valley that included the disputed lands. To inaugurate this anticipated happy period, the parish priest, in the presence of a large assemblage of people, held a solemn mass and blessed the sacred symbol.

Some days passed in peace, until it was discovered that the cross had been cut down and had disappeared, an act of sacrilege committed perhaps under the misapprehension that the cross was intended to fix the disputed boundary line. The finger of suspicion pointed to a poor stutterer, Padilla of Parícutin, who henceforth lived in some anxiety and danger.

The Tarascan tharepeti, a council of patriarchs that met periodically to deliberate matters of communal interest and to augur the signs of the future, considered this event with dark forebodings and prognosti- 
cated a punishment without equal, a punishment that would cause their misery and ruin. Sra. Justina Sánchez, of Parícutin, no doubt influenced by the prediction of the tharepeti, saw in her dreams a fire issue from the earth and consume everything. This incident, which the outbreak of the volcano seemed later so strikingly to confirm, profoundly impressed many of the people.

While the sacrilege of the cross was generally considered the major sin that brought the destruction to the region, there were persons who believed that their personal slight sins were a contributory factor.

In spite of these beliefs as to its ultimate cause, the people recognized the volcano as a natural phenomenon and readily connected the growing cone and the flowing lava with similar features of the region with which they had an everyday familiarity-the wooded cones, the cultivated valleys and benches, and the rugged malpais.

\section{BIRTH OF PARÍCUTIN VOLCANO}

\section{EARTHQUAKES}

Early February is the season when the villagers are in their fields, cleaning the land or otherwise occupied in preparing for the first plowing of the year. It was then that the first premonitive tremors were felt and the first subterranean noises heard.

Celedonio Gutiérrez has given us some account of the few weeks preceding the outbreak of the volcano, a translation of which is given here:

The year 1943 began. When I visited a friend on a ranch called Titzicato, some few kilometers south of where the new volcano broke forth, he told me that some tremors had already begun in these places and they heard many noises in the center of the earth. These tremors began to be felt in San Juan [Parangaricutiro] the following month, the 5th of February, at midday, and every day until the 20th. During these 15 days of tremors there were some stronger than others; when we heard the subterranean noises we awaited the tremor. According to the noise the movement of the earth was strong or weak. They followed each other almost every minute. If they were delayed the noise or the tremor was stronger.

The people could not feel secure nor have confidence to remain in their houses to sleep. They knelt down frequently to pray to God that the earth would not sink, such was the movement during so many days of earthquakes. They brought forth the Image of the Santo Cristo Milagroso, of this village, in procession and the earthquake ceased. I write this because I have seen it and not because it was to told me.

The priest Sr. José Caballero, then parish priest of San Juan Parangaricutiro, related that light earth tremors began to be felt on February 7, 1943. On the 15 th, at 5 p. m., they reached an alarming intensity. At 10 a. $\mathrm{m}$. on the 20 th subterranean noises were heard in San Juan Parangaricutiro; and the tremors were then, without exception, oscillatory. Sr. Caballero recalled that when he first came 
to San Juan Parangaricutiro and Parícutin as parish priest in 1933 the walls of the churches of both villages were fissured to a notable extent, suggesting to him that tremors were already active at that early date.

Professor Ruperto Torres L., editor of a newspaper at Uruapan and a resident of that town for many years, related that some 2 years before the outbreak of Paricutin volcano, rather weak tremors were felt in the region. No particular significance was ascribed to them, since they were generally considered to be tectonic tremors with an origin in the Pacific Ocean, a not infrequent occurrence in the littoral of Colima, Michoacán, and Guerrero. According to Professor Torres, tremors were again felt on the 5 th of February 1943, but no importance was attached to them. By February 10 the tremors were more frequent and of greater intensity but were still considered to have a distant origin. On the 20th a messenger from San Juan Parangaricutiro arrived in Uruapan with word from the presidente, Sr. Felipe Cuara Amezcua, to the presidente of Uruapan, reporting in alarming terms that the region of San Juan Parangaricutiro and Parícutin was experiencing such strong and frequent tremors that neither the municipal nor church authorities, nor the people, knew what to do. On the same evening a second messenger arrived with word that the tremors had ceased but that a volcano had broken out between the fields of Cuiyúsuru and Quitzocho. An urgent plea for help was then dispatched to the Governor of the State at Morelia.

According to Sr. Felipe Cuara Amezcua, earth tremors began to be noticeable on February 5, 1943, increasing in number and intensity until more than 200 were experienced in a day. The tremors became so frequent and strong that it was feared that the church at San Juan Parangaricutiro, with its massive masonry walls, would collapse. The parish priest, José Caballero, had the image of the saint El Señor de los Milagros removed to the plaza, facing, by a strange coincidence, the point where the new volcano would break out. These tremors were accompanied by subterranean noises. Both the tremors and noises seemed to center in Cuiyúsuru, which led him to believe that Cerro Prieto, an ancient cone which lay immediately adjacent to the farm, would break its agelong rest and erupt.

According to Robles Ramos (1943) the earthquakes varied between intensities 3 and 4, Mercalli's scale.

\section{SOURCES OF INFORMATION}

For about a week or more before the initial outbreak of Parícutin volcano, accounts appeared in Mexico City newspapers mentioning the recurrent earth tremors in the Uruapan region. In one of these accounts the presidente municipal of San Juan Parangaricutiro, Sr. 
Felipe Cuara Amezcua, predicted a new volcanic outbreak. In spite of this warning, available geologists were unprepared for the event that followed. Fortunately, the manifestation was witnessed by several inhabitants of the area, Tarascan Indians, whose keen perception and innate knowledge of natural phenomena are responsible for the first adequate account of the birth of a new volcano.

Among the actual eyewitnesses to this unusual event, we were able to interview Sr. Dionisio Pulido, owner of Cuiyúsuru, the farm that brought forth the volcano; Sra. Paula Cervantes Rangel de Pulido, his wife; Sr. Dolores Pulido, his brother; all of Parícutin; and Sra. Aurora Cuara of San Juan Parangaricutiro.

Demetrio Toral, a laborer from Parícutin employed by Pulido as helper, was plowing land at Cuiyúsuru. He had just completed a furrow and was about to turn his plow when the first outbreak of the volcano occurred almost in the exact furrow he had just drawn. This remarkable circumstance has led some people into the belief that Toral "plowed up the volcano." Toral, a deaf mute, died soon after in Caltzontzin.

It has been reported that José María Isidro was also present at the outbreak of the volcano, but we have been unable to locate him.

A lad of San Juan of Parangaricutiro, hearing the accounts of the outbreak being discussed by the townspeople in the plaza, went to Ticuiro, a field near the edge of town, and took photographs (pl. $16 A, B)$ of the event. The time was about $5 \mathrm{p} . \mathrm{m}$.

Immediately after the outbreak of the volcano, the presidente municipal of San Juan Parangaricutiro sent a group to the spot to investigate the event. Of the group members we succeeded in finding Juan Anguiano Espinosa, Jesús Martínez, and Luis Ortíz Solorio and obtaining from them an account of the events that occurred an hour or so after the initial outbreak.

Among the officials of the municipio who contributed accounts were the presidente municipal Sr. Felipe Cuara Amezcua and the parish priest, Sr. José Caballero. Sr. Celedonio Gutiérrez, of San Juan Parangaricutiro, has maintained a diary since the beginning of the volcano's activity and has given us access to a copy of this valuable document. Finally, the event is succinctly described in the official records of the municipio of San Juan Parangaricutiro, a certified copy of which Sr. Cuara Amezcua prepared for us.

\section{DIONISIO PULmo}

Dionisio Pulido was a resident of the village of Parícutin. For 31 years he was owner of Cuiyúsuru farm. He is now a resident of Caltzontzin, near Uruapan, a village organized to accommodate the former inhabitants of Parícutin. His farm was divided into three 
parts: one which he worked himself, one which he shared with his brother Dolores, and one which he rented on shares to others. Upon his land was a small hole (mentioned by Sra. Murillo) with an apparent depth of $1 \frac{1}{2}$ meters. Year after year he and Dolores cast dirt and debris in this hole without succeeding in filling it. Frequently Pulido hid his ox yoke and plow in it to spare the trouble of bringing them to Parícutin. Before January 1943 nothing unusual about his farm attracted his attention. Its picturesque and peaceful environment pleased his Tarascan nature. Never, not even on the day of the initial volcanic outbreak on Cuiyúsuru, did he note any unusual warmth in the ground, as has been so frequently stated in popular accounts of the event.

On February 20, 1943, Pulido left his village, going to his farm to prepare the fields for the spring sowing. He was accompanied by his wife, Paula, his small son, who would watch the sheep, and Demetrio Toral, his helper, to begin the plowing. The day was calm, and the sky was clear. Pulido's account, as he related it to us, follows:

In the afternoon I joined my wife and son, who were watching the sheep, and inquired if anything new had occurred, since for 2 weeks we had felt strong tremors in the region. Paula replied, yes, that she had heard noise and thunder underground. Scarcely had she finished speaking when I, myself, heard a noise, like thunder during a rainstorm, but I could not explain it, for the sky above was clear and the day was so peaceful, as it is in February.

At $4 \mathrm{p}$. m. I left my wife to set fire to a pile of branches which Demetrio and I and another, whose name I cannot remember, had gathered. I went to burn the branches when I noticed that a cueva, ${ }^{4}$ which was situated on one of the knolls of my farm, had opened, ${ }^{5}$ and I noticed that this fissure, as I followed it with $\mathrm{my}$ eye, was long and passed from where I stood, through the hole, and continued in the direction of Cerro de Canicjuata, where Canicjuata joins Mesa de Cocjarao. Here is something new and strange, thought I, and I searched the ground for marks to see whether or not it had opened in the night, but could find none; and I saw that it was a kind of fissure that had only a depth of half a meter. I set about to ignite the branches again when I felt a thunder, the trees trembled, and I turned to speak to Paula; and it was then I saw how, in the hole, the ground swelled and raised itself 2 or $2 \frac{1}{2}$ meters high, and a kind of smoke or fine dustgray, like ashes-began to rise up in a portion of the crack that I had not previously seen near the resumidero. Immediately more smoke began to rise, with a hiss or whistle, loud and continuous; and there was a smell of sulfur. I then became greatly frightened and tried to help unyoke one of the ox teams. I hardly knew what to do, so stunned was I before this, not knowing what to think or what to do and not able to find my wife or my son or my animals. Finally my wits returned and I recalled the sacred Señor de los Milagros, which was in the church in San Juan (Parangaricutiro) and in a loud voice I cried, "Santo Señor de los Milagros, you brought me into this world-now save me from the dangers in which I am about to die;" and I looked toward the fissure whence rose the smoke; and my

\footnotetext{
4 Variously referred to by Pulido as a cueva (cave or grotto), resumidero (a hole or crevice, into which water disappears during the rainy season), or agujero (a hole).

${ }^{6}$ In another account Pulido described the initial noise as a pop, as one hears upon opening a bottle of carbonated beverage.
} 
fear for the first time disappeared. I ran to see if I could save my family and my companions and my oxen, but I did not see them and thought that they had taken the oxen to the spring for water. I saw that there was no longer any water in the spring, for it was near the fissure, and I thought the water was lost because of the fissure. Then, very frightened, I mounted my mare and galloped to Parícutin, where I found my wife and son and friends awaiting, fearing that I might be dead and that they would never see me again. On the road to Paricutin I thought of my little animals, the yoke oxen, that were going to die in that flame and smoke, but upon arriving at my house I was happy to see that they were there.

Upon his arrival at Parícutin, Pulido reported the event to the Chief of the Parícutin subdivision, Sr. C. Agustín Sánchez, who then accompanied him to San Juan Parangaricutiro to report to the presidente of the municipio, Sr. Felipe Cuara Amezcua.

On the following day Pulido drove his oxen to the forest to graze and then went to his farm to see what had occurred. When he arrived there at $8 \mathrm{a} . \mathrm{m}$., he saw that a hill, which he estimated to be 10 meters high, had formed and that this mound emitted smoke and hurled out rocks with great violence.

Alfonso de la $O$ Carreño (1943) states that a light seism accompanied by subterranean noises and followed by a distant detonation was perceived at San Juan Parangaricutiro on Saturday, the 20th, at 5:20 p. m. Pulido reported to him that, at $4 \mathrm{p}$. $\mathrm{m}$. and before, he walked about his farm hearing noises like those of a heavy freshet, that the sky was cloudless, and that he looked in all directions to localize the noise. Then suddenly he saw a large column of black smoke arise from a depression, and a fissure, 5 centimeters wide, open in the soil; and he was able to follow the eastward-trending fissure with his eye for 30 meters.

\section{Paula pulido}

Paula Cervantes Rangel de Pulido, wife of Dionisio Pulido, accompanied her husband to watch the sheep. She is Tarascan; and although she understands Spanish, she does not speak it. Dolores Pulido acted as our interpreter. Sra. Pulido also related her account to Sra. Amalia Vargas de Ortiz, of San Juan Parangaricutiro, who in turn told it to us. According to Sra. Ortiz, Paula Pulido spent part of the day in the shade of an oak, watching the sheep grazing on the sparse herbage. As the sheep moved on she changed her position to another nearby tree, and it was from there that she saw a small whirling dust column (remolinito) follow a small fissure in the soil, moving from a point called Quijata to Cuiyúsuru, a distance of about a kilometer. A kind of fissure 5 centimeters wide and 30 centimeters deep opened as the dust column moved toward Cuiyúsuru depositing a pale-gray dust. The column stopped near the oak tree she had left a short time before, and a hole 30 centimeters wide opened, and a 
smoke began to rise. Her first reaction was one of surprise and delight in watching the "pretty remolinito" as it traveled along, fissuring the soil.

Her account to us, through Dolores Pulido, follows:

About 4 p. m., after talking to my husband, I heard a kind of loud whistle, like the noise of water falling on live coals or hot embers. This noise was completely distinct from the underground noise I had been hearing, and the trees swayed strongly and continuously. I was about 100 meters from the place where these things took place, when I saw, issuing from a crevice that had formed, a little cloud of gray and I smelled an odor like sulfur, and I noticed that some pines about 30 meters from the orifice began to burn. I called to my husband. Then the ground rose in the form of a confused cake above the open fissure and then disappeared, but I cannot say whether it blew out or fell back-I believe it swallowed itself. I was sure the earth was on fire and it would consume itself. From the fissure arose a gray column of smoke, without force, depositing a fine gray dust.

Now very much frightened, Paula Pulido fled to Parícutin and there awaited with great anxiety some word of the fate of her husband.

\section{DOLORES PULTDO}

On the afternoon of February 20, Dolores Pulido was working in the forest on Cerro de Janánboro. He saw a column of smoke arising from Cuiyúsuru; and since he was part owner of land there, he went to see what was taking place. He reached the spot about $6 \mathrm{p} . \mathrm{m}$. and saw smoke issuing from a hole in the ground. About this vent were low mounds of fine gray ash. He was unable to approach closer than 8 meters because of falling stones. He then took fright and fled. He returned to the place the next morning and found a gentle rain of "sand" falling about the spot.

\section{AURORA CUARA}

All during the day of February 20, while Gregorio Cuara and his family were at their farm at San Nicolás about 20 kilometers from San Juan Parangaricutiro, they felt strong tremors and heard subterranean noises resembling the noise of a motor or a stone rolling down a rocky slope. The trail from San Nicolás to San Juan Parangaricutiro passes Quitzocho and almost at the foot of Piedra del Sol. Sra. Aurora Cuara, a Tarascan woman of unusual intelligence and perception, and one of her children were returning to San Juan Parangaricutiro by this path and had reached Piedra del Sol about 4:30 p. m. There Sra. Cuara saw Pulido gathering branches and weeds into a pile and saw his helper, Toral, complete a furrow in his plowing, passing over the precise point where the earth was to open a moment later. As the helper was about to make the turn to commence a new furrow, a fissure split the earth in a direction toward Cerro de Canicjuata. The earth rose as a wall 10 meters long and 2 
meters wide to a height of about a meter, and a gray smoke of a very fine gray dust ascended. Although greatly frightened, Sra. Cuara climbed Piedra del Sol, in order to observe better this unusual event. The fissure was no more than 50 meters away. In addition to the small dust column, she also saw "sparks" thrown out. She watched Pulido try to help unyoke the oxen; and when he fled in fright she, too, lost courage and, with her child, ran toward the town. A drawing from a sketch by Sra. Cuara (fig. 110) shows the position of the various features and eyewitnesses as she saw them.

At 10 o'clock at night she could clearly see from San Juan Parangaricutiro, between the pine trees of the forest, incandescent bombs thrown into the air. Sometime between 11 and $12 \mathrm{p}$. m., the new volcano began to roar, incandescent stones were hurled up with great force, and a column of smoke, illuminated by lightning flashes, arose.

The following day, about 11 a. m., Sra. Cuara returned by the same path to see what had happened to her husband in San Nicolás. A small hill of stones of various sizes and of sand had formed about the vent where the smoke had first found exit. Some of the rocks hurled from the vent were very large and exploded in the air. She described

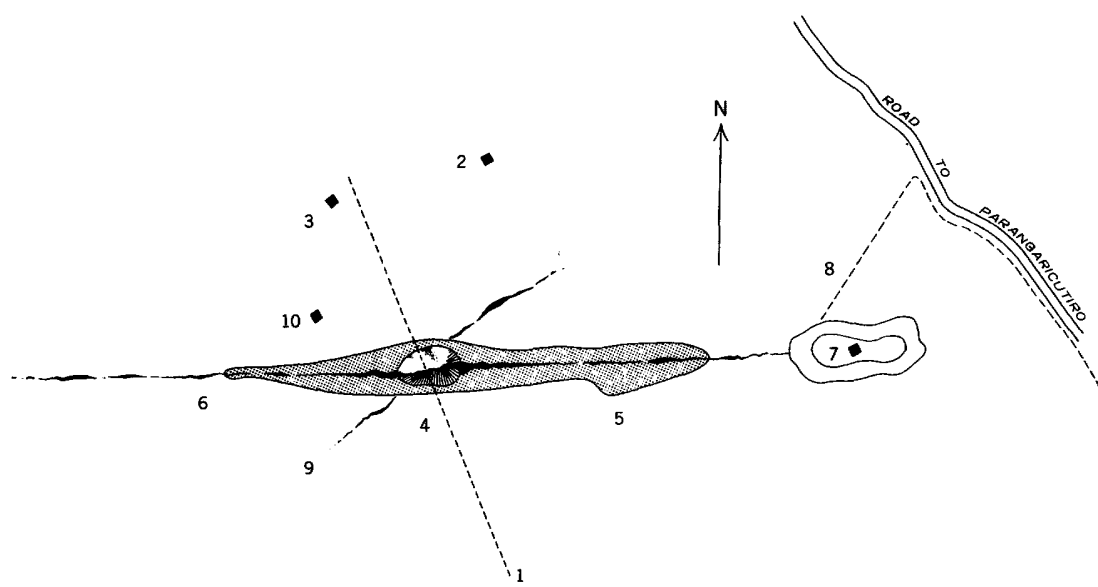

FIGURE 110.-Parlcutin volcano at the time of its initial outbreak, showing the positions of the various features and eyewitnesses as seen by Sra. Aurora Cuara.

1. Direction of Toral's plowed furrow.

2. Position of Dionisio Pulido.

3. Position of Demetrio Toral.

4. Vent of the volcano.

5. Depression along the fissure.

6. The original fissure.

7. Piedra del Sol.

8. Path taken by Aurora Cuara.

9. A secondary crack of fissure.

10. Position of Paula Rangel de Pulido. 
the little hill as round in form, and she could clearly see a fire, which she afterwards learned was lava, issue slowly from the bottom of it.

\section{LUIS ORTIZ SOLORIO}

Luis Ortíz Solorio was standing on the street corner near his house in San Juan Parangaricutiro talking to his neighbor the shoemaker. It was a quarter past 5 in the afternoon. Ten minutes later, looking toward Quitzocho, he saw a thin column of smoke arising. He went to the plaza, where many people were gathered in front of the church, for news had come that the earth had opened and smoke was issuing from a crack in the ground on Cuiyúsuru. The parish priest, Sr. José Caballero, with the permission of the presidente, Sr. Felipe Cuara Amezcua, decided to send a group of men to the spot to see what had taken place. Solorio offered to go and was joined by Jesús Anguiano, Juan Anguiano Espinosa, Epitacio Murillo, Hilario Anguiano, Epitacio Clasope, Justiniano Cirícuti, and some others whose names Solorio has now forgotten.

The priest first gave them his blessing, and they went on horseback, riding rapidly, and arrived at the spot at about $6 \mathrm{p} . \mathrm{m}$. In the soil of Cuiyúsuru they saw a sort of fissure, at the southwest end of which was a hole about a half a meter in diameter from which smoke issued and some hot rocks were hurled not very high in the air. Juan Anguiano Espinosa and Jesús Martínez, in order to obtain a nearer view, approached close to the hole. Solorio then saw a fracture forming about 6 meters from the center of the vent and called to Espinosa and Martínez to come back. Hardly had they leapt back when the wall fell in, widening the orifice to 2 meters and increasing the size of the smoke column.

When they returned to San Juan Parangaricutiro, they related what they had seen, how the earth had opened and how smoke and small stones, like incandescent marbles and oranges were being cast out from a vent that continued growing bigger. The priest then consulted a book on Vesuvius in the church library, and they were convinced that they had seen a volcano.

\section{ANGUIANO AND MARTINEZ}

Juan Anguiano Espinosa and Jesús Martínez, both about 22 years old and of San Juan Parangaricutiro, were the first of the group leaving the plaza to arrive at Cuiryúsuru. They found the soil fissured in the form of a trench and saw a hole from whence smoke issued. Around the hole was a slumped area about 20 meters long and 12 meters wide, bounded by a crack along which were low mounds, one-half meter high, of very fine hot dust. This dust was gray, like ashes or cement; and Anguiano, wrapping a handkerchief about his hand, collected a 
sample of it to show in the village. From the vent itself fine dust, "sparks," and stones were thrown out. Anguiano and Martínez approached within a few meters of the vent, where a choking odor pervaded and the ground shook violently, "jumping up and down, not with the swaying motion we felt in Parangaricutiro." In the vent the sand "boiled" vigorously like the bubbling sand in a rising spring, with a noise like a large jug of water boiling violently, or boulders dragged along a stream bed by a river in flood. Small stones were cast up to a height of 5 meters. Anguiano collected two and found them very hot. ${ }^{6}$

The fissure in the soil extended in a direction toward the setting sun, that is, toward the point where Cerro de Canicjuata joins Mesa de Cocjarao, and the spring that supplied water to Parícutin. In the plan prepared for us by Anguiano, he indicated a small cross fissure, passing southwestward through the vent.

Anguiano modeled the appearance of the vent and its surroundings in the soil for us, a sketch of which is shown in figure 111.

In the plaza of San Juan Parangaricutiro the townspeople awaited their return with great anxiety. They related what they had seen, and Anguiano delivered the ashes and two bombs to the priest. The stones, being still hot, were placed in a dish; and the priest exorcised

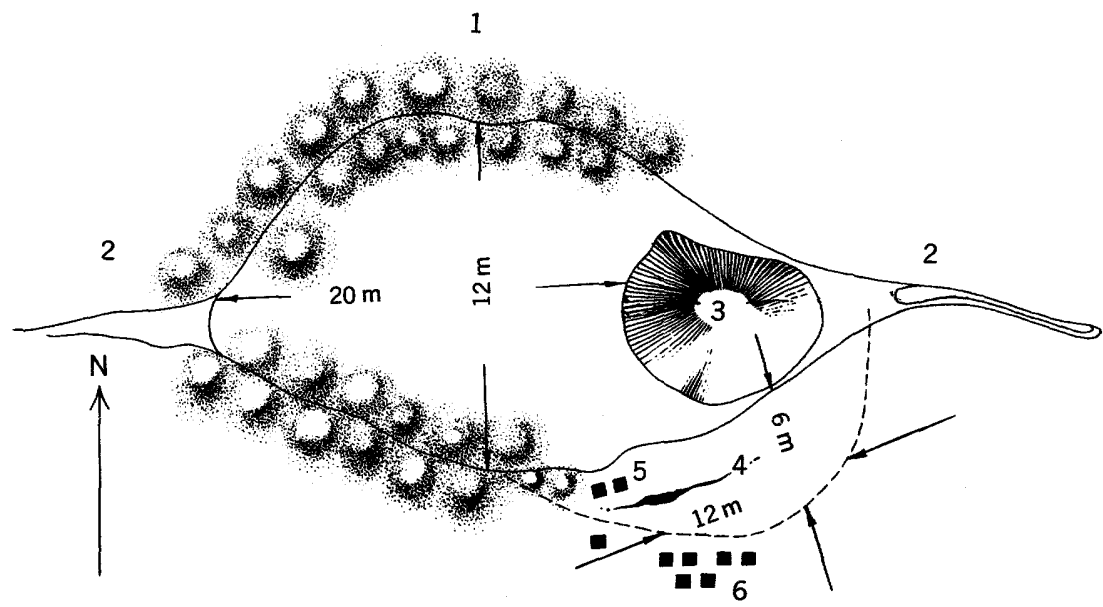

Figure 111.-Paricutin volcano at 6 p. m., February 20, 1943, showing the appearance of the vent and its surroundings as seen by Juan Anguiano $\mathbf{E}$.

1. Small mounds of gray ash.

2. The fissure that opened.

3. The pit from which vapors issued.

4. The fracture that opened while Anguiano and Martínez watched the vent.

5. Anguiano and Martinez.

6. Other members of the Parangaricutiro party.

${ }^{6}$ These two bombs were later presented to us by the parish priest, Sr. Jose Caballero. One is now in the collection of the Instituto de Geologia in Mexico, the other in the U. S. National Museum. The ash collected by Anguiano was presented to the Bishop of Zamora.

338669 O- $55-3$ 
them, imploring Heaven to cease this terrible apparition, as a benediction and grace to the inhabitants of the region.

Anguiano added that for 14 hours before the outbreak of the volcano frequent tremors shook San Juan Parangaricutiro and the subterranean noises that accompanied these tremors seemed to come from Cerro de Jarátiro.

\section{CELEDONIO GUTIF́RREZ}

Celedonio Gutiérrez, of San Juan Parangaricutiro, was not an actual witness to the initial outbreak of the volcano but was in the town when the event occurred. Being an unusually keen and competent observer, his account of the first few days has more than ordinary value. Gutiérrez wrote for us the following account:

When I returned from my work in the fields, I saw a gray column of smoke arise from the place where the parcels of Quitzocho and Cuiyutziro [Cuiyúsuru] were located and that this column spread little by little. It was 4:30 o'clock in the afternoon of the 20th of February 1943. When I reached the ehurch, I saw the presidente municipal, the parish priest, and many people gathered in the plaza. Quickly they ordered that a group of men go to investigate what it was that was burning. After a time the men returned saying that the earth had opened in Cuiyútziro, splitting it in the form of a crevise running from east to west, and that there, and from a hole that had also opened, fine sand and very hot stones issued, collecting in small mounds on both sides of the crevise and that they made a terrifying noise as they were ejected.

With the outbreak of the volcano, the earth tremors ceased, much to the relief of the populace. The priest and presidente allayed their fears somewhat, but on the morning of the 21st a strong earthquake threw them into panic, and they abandoned their homes; those from Parícutin fleeing to [San Juan] Parangaricutiro, those from Parangaricutiro to Angahuan or Uruapan, and those from Angahuan to the mountains.

The volcano broke out on Saturday, February 20, at about half past 4 in the afternoon. What a great surprise for my village and for the world! The earth was burned, and there began to ascend a small simple column that grew little by little; a vapor of strange gray rising silently toward the southeast. A little later many people came from Parícutin, which was nearest to the volcano. The presidente municipal, Don Felipe Cuara A., prepared to move the people from the place and had already asked, by means of telegraph, for trucks to transport all the people. But the people despaired and began to leave on foot, on horse, or on burros, or however they were able.

In the afternoon, when night began to fall, one could hear more noises. These we called rezaques. ${ }^{7}$ Some tongues of flame began to appear, as of fire, that rose about 800 meters into the air, and others even higher that loosened a rain, as of artificial golden fire. At 8 or 9 at night, some flashes of lightning shot from the vent into the column of vapor. The column was now very dense and black and extended toward the south. It covered the grand mountain of Tancitaro, for the first sand and ashes were in this direction and cast the first cold shadow of the volcano over this area. From this hour the warming rays of the sun that warmed the mountains and the beautiful green fields ceased, and the green leaves

\footnotetext{
7 Perhaps resacas, or surges, like surf upon a shore, is meant.
} 
of the trees and the smaller plants that nourished the cattle died from the ashes that now began to appear. How strange and rare to see the clouds form, the first clouds of the volcano. Only a short time before the sky was blue, for the dry season had already begun. So, then, we passed the first night, contemplating and admiring this new event.

On the following day, Sunday the 21st, the dense vapors ceased. When the vapors diminished, the noise increased; and at 2 in the afternoon they were very strong. With each blast, white vapors accompanied by blue flames arose; the vapors appeared as if one shook a white sheet in the air.

After the first night, it threw up some tongues of fire, which were almost of pure sand. On the following night one noted that they were explosions of bombs and that the stones rose to a height of 500 meters. They flew through the air to fall 300-400 meters from the vent. It is a great memory for me to have seen, during these first days, how the first stones fell on the plowed fields of Quitzocho, where I used to watch the cattle of my grandfather.

At 3 o'clock on the morning of Monday, the 22d, there were earthquakes like we never had before. The earth shook for 7 or 8 minutes, with intervals of a few seconds. The people imagined that this was the ultimate agony of a great region. Who could check the great movement of an entire region? ${ }^{8}$ Only the omnipotent God, in his great power, with his divine omnipotence, thought of us. It was He who saved us.

The first lava that the volcano gave forth, to the east of the little cone, flowed 3 meters per hour, according to the data of Sr. Geologist don Ezequiel Ord6nez, who was sent by the Comision Impulsora y Coordinadora de la Investigacion Cientifica, México, D. F., to observe this important novelty. This gentleman, 78 years of age, through his studies and experience, convinced us that there was no danger to our village and counseled that the people return to their homes. Now this same gentleman showed us the first lava flow, moving like dough, from which fell incandescent rocks from one side or another, such rocks as we knew before; without knowing how they formed. We also saw the malpais, which we knew before, without an idea of its origin. Without doubt, this answers not only how the malpais formed but also the tillable land and the mountains that $I$ knew. We saw the lava as it covered the cruza ${ }^{9}$ made by the yokes of oxen from Parícutin and which needed only 8 days for sowing. Now one sees an admirable flow of fire, covering the last traces of our footsteps and of the works of man that he made during the life that God permitted him.

\section{RECORD OF SAN JUAN PARANGARICUTIRO}

Sr. Felipe Cuara Amezcua, presidente of the municipio of San Juan Parangaricutiro, has provided us with a certified copy of the record of the meeting of the municipal council signed by the council members, which is, as far as the municipal records are concerned, the official history of this unusual event. A translation of this document follows:

In the village of [San Juan] Parangaricutiro, seat of the municipality of the same name, State of Michoacán de Ocampo, at 10 o'clock on the 21st day of the month of February 1943, gathered in the public hall of the municipal government, under urgent summons, the councilmen: Felipe Cuara Amezcua, municipal mayor; Félix Anducho, trustee; Rafael Ortiz Enriques; Ambrosio Soto; and Rutilio Sandoval; as well as Agustín Sánchez, resident of said place. The Regidor, Felipe

8 This earthquake had its epicenter in the sea, near Acapulco, and was not directly related to the volcano.

Second plowing in preparation for the sowing. 


\section{GEOLOGIC INVESTIGATIONS IN THE PARÍCUTIN AREA, MEXICO}

Cuara Amezcua, President, declared the session opened, stating that yesterday at about 6 p. m., Messrs. Sánchez and Pulido presented themselves, telling, greatly excited, of the appearance of a strange conflagration that occurred at $5 \mathrm{p} . \mathrm{m}$. yesterday in the valley called Cuiyutiziro [Cuiyúsuru], to the east of the village of Parícutin. They asked that they be taken immediately to the place of the happening that one could see for oneself the truth of their assertion; at the time Dionisio Pulido, owner of the above-mentioned property, gave the information that early on the day of the event, he left his village [Paricutin] to tend his sheep in company with his wife Paula Rangel de Pulido and to visit his properties situated in the said valley; that in the afternoon, at an early hour, he left the place, asking his wife to watch the sheep until he returned; that about $4 \mathrm{p.} \mathrm{m}$. he returned to the place and asked Demetrio Torres [Demetrio Toral] who worked in the fields, to unyoke the oxen and take them to water, after which he returned to his wife suggesting that she return to the village, going then to examine the work done in the fields, arriving at the slope of the nearby hill to the east; that there, about $5 \mathrm{p}$. $\mathrm{m}$., he felt a strong tremor and din in the earth, to which he paid little attention, since seisms had been frequent for more than 8 days, but he continued hearing loud subterranean noises accompanying the tremors, and then, thoroughly frightened, he turned his gaze to the west, that is, toward his village, observing with surprise that down there in a depression long tongues of fire arose, with a great deal of smoke and noises never heard before. A terrible panic seized him, and he fled toward Paricutin, where he arrived out of breath, immediately recounting to C. Agustín Sánchez, chief of the Parícutin subdivision, what had occurred. That Señor Sánchez, convincing himself of the truth of what Pulido had told him, went with him to the municipal president of Parangaricutiro where, totally alarmed, they gave the facts to C. Felipe Cuara Amezcua, who with the haste the case merited, went with the informants to the place where the phenomenon had appeared, and later they learned that it was a volcano. Returning to Parangaricutiro, the municipal president summoned the members of the council to attend the present extraordinary session and consider this matter, now that the fear has extended to all the nearby villages, and solicit, for this reason, ample powers from the council to act; he gave as important in the case that now the volcano grew with real fury and, with it, the panic of the inhabitants of the region who abandoned their homes and possessions. It was conceded at once to C. Felipe Cuara Amezcua, who immediately began action to solve the problem in the best manner, soliciting by telephone and telegraph the help of General of Division, don Manuel Avila Camacho, Constitutional President of the Republic; General of Division, don Lázaro Cárdenas, Secretary of National Defense; of General Félix Ireta Vivieros, Governor of the State; the Department of Agriculture and Government; municipal authorities of Uruapan; and other official agencies. Upon the proposal of some residents of this place and of Paricutin, the correct name that the mentioned volcano should bear was discussed, and after ample deliberation, in which was taken into account the history, traditions, and desires of the people, it was unanimously denominated "Volcán de Parícutin."

\section{SUMMARY OF ACCOUNTS}

After a fortnight of subterranean noises and local earthquakes that appeared to center between Cerro de Jarátiro and Cerro Prieto, lying to the southeast of Parícutin village, and which continually increased in number and intensity, a small fissure appeared in the soil of the cultivated lands of Cuiyúsuru farm. This fissure, beginning near 
Piedra de Sol, extended westward toward a point where Cerro de Canicjuata joins Mesa de Cocjarao and passed through a small cave or sink on Cuiyúsuru farm. The fissure had an observed length of about 50 meters, a width of 5 centimeters, and an apparent depth of only $1 / 2$ meter. A small subsidiary fissure having a southwest direction also formed. The evidence suggests that the fissure opened during the afternoon of February 20, probably about 4 o'clock, or half an hour before the initial outbreak of the volcano. At about 4:30 p. m. at a point on the fissure sulfurous gases and steam were emitted with a pop, followed by a whistling noise; and a small eruptive column arose from the newly formed vent.

The vent was originally of small size, about 30 centimeters in diameter, according to Paula Pulido; and the eruptive column consisted of fine dust and small incandescent stones. The vent gradually widened by slumping of its walls, and the eruptive column gradually increased in size (pl. 16A, B). Ejected stones collected during this period consisted of fragments of basalt different in character from Paricutin lava, and probably represent the walls of the fissure. (See table 2.)

Some time between 11 and $12 \mathrm{p} . \mathrm{m}$. the activity of the new volcano became violent; incandescent rocks were violently ejected in great numbers, and a large eruptive column, accompanied by frequent lightning flashes and a tremendous roaring sound, arose from the newly formed vent. This change in activity suggests that the advancing gases of the initial phase were followed by the rising lava column and that it reached the surface at this time.

\section{DEVELOPMENT OF PARÍCUTIN VOLCANO}

After the initial outbreak of Parícutin volcano on February 20, $1943,2 \frac{1}{2}$ years were to pass before it became apparent that the new volcano had acquired a definite pattern of activity and that the volcano could be considered a well-established and mature volcanic edifice. This interval of development may be divided into three periods, depending primarily upon the vent with which the principal activity was associated. These we propose to call the Quitzocho, Sapichu, and Taquí periods.

The first, or Quitzocho period, endured from February 20 to October 19,1943 . The activity was centered exclusively in the original Cuiyúsuru vent, about which the volcano built its cone. The important feature during this period was the growing cone and the accidents that befell it. At the end of this period the cone had almost reached its full height, or about 365 meters, and had acquired a considerable degree of stability. 
This period was to terminate suddenly with the outbreak of new vents, the Sapichu vents, at the northeast foot of the cone.

The Sapichu period, covering the activity of the Sapichu vents, lasted from October 19, 1943, to January 8, 1944. A small adventitious horseshoe-shaped edifice, called Sapichu, was built about this vent; but the principal feature was the almost constant emission of lava to form a broad flow. During the Sapichu period, activity in the Cuiyúsuru vent (the main crater) was greatly reduced, and no significant changes took place in the main cone.

With cessation of lava emission from Sapichu, activity shifted to two vents, the Taquí and Ahuán, on the west and south sides of the cone respectively. A period of almost continuous extravasation of lava set in, during which the cone showed erratic and variable activity but no significant change in configuration. This period we have called the Taquí period.

The account that follows will be considered according to these three periods: Quitzocho period, building of the cone; Sapichu period, eruption of the adventitious cone Sapichu; Taquí period, lava flows.

\section{QUITZOCHO PERIOD}

\section{FARLY FXPLOSIVE PHASE}

February 21.-One may consider the Quitzocho period of Parícutin volcano as beginning at midnight, February 20. The vent now had 7 hours of development, and the first small beginning of the cone became apparent. At midnight, February 20, the cone was 6 meiers high and elongate in form, with its long axis east and west (Robles Ramos, 1943). About this time the first thunderous roars were heard in San Juan Parangaricutiro. The earth tremors that were felt during the past fortnight now ceased and were not felt again. At 4 a. m. February 21 , the cone was estimated as being 8 meters high. Dionisio Pulido visited his farm at $8 \mathrm{a} . \mathrm{m}$. and reported the cone as 10 to 12 meters high. Mauricio Duarte estimated the height as 25 meters at 10 a. $\mathrm{m}$. and that the column rose higher than Cerros de Tancítaro. Jorge Treviño described the volcano as a low cone with an oval crater at 11 a. m., from which arose a black eruptive column accompanied by strong explosive blasts. Sra. Aurora Cuara, who passed the volcano at $11 \mathrm{a} . \mathrm{m}$., described it as a small round hill of stones, from which rocks were hurled into the air. From the bottom of this hill a "fire" slowly issued. Between $12 \mathrm{~m}$. and $1 \mathrm{p} . \mathrm{m}$. the volcano began again to eject many bombs, the bursts spreading in the form of a fan and dropping bombs in a wide east-west zone. At $1 \mathrm{p}$. $\mathrm{m}$. the cone was estimated as 30 meters high, with a base 70 meters in diameter. Jorge Treviño estimated that on this afternoon 
the cone was 50 meters high. Celedonio Gutiérrez reported that the eruptive column diminished in size during the early part of the day and that the ejectamenta changed from ash to bombs accompanied by white vapors and blue flames. These bombs were hurled to a height of 500 meters, some falling 300 to $\mathbf{4 0 0}$ meters from the cone.

Photographs of the volcano by Dr. J. Trinidad and Salvador Ceja (pl. 17 A) and motion pictures by Jorge Treviño show the cone as a low dome, with slope angles of $32^{\circ}$ toward the west but more gently inclined toward the east. This asymmetry of the cone indicates that it had already been breached and that lava had already flowed toward the east. The eruptive column, as shown by motion pictures, rose rather lazily without well-defined volutes or cauliflowers. Large tatters of lava up to a meter across were ejected in abundance. According to Celedonio Gutiérrez, these had imitative shapes, resembling birds and objects, indicating that they were still plastic. At least two neighboring vents were present in the crater. The western vent appeared more active and its column more heavily laden with ash; the eastern vent was erratic in its action and appeared to be somewhat smaller than the western vent. The eastern vent ejected more large bombs and coarser material than the western vent.

The eruptive activity of February 21 is described by Celedonio Gutiérrez (personal communication) as follows:

On this day, which was Sunday, between one o'clock in the morning and until 12 o'clock, the eruption of the volcano did not vary much from that of late yesterday. The eruptive column was like that previously observed, rising towards the heavens in large agitated cauliflowers, which left the erater with great force, and from which fell much ash and many bombs. The only difference noted was that now one saw no electrical discharges.

Between 12 and 13 o'clock the volume of ejected material began to diminish and ash ceased to fall. Bombs continued to be thrown out but in less quantity, and there began deep, heavy, thunderous noises, increasing in intensity.

Between 13 and 15 o'clock the explosions increased in both force and frequency; the amount of material, however, diminishing each time but the fear of the people of San Juan [Parangaricutiro] increased. One could see with each explosion in the volcanic vent small white clouds of smoke arise with great force, like from the mouth of a cannon. The explosions were extraordinarily violent, greater than cainnonading.

From 15 o'clock until 3 o'clock [February 22] the form and type of the explosions showed no change.

Other observers described the cone as having a horseshoe form, open toward the northeast. The dark-gray eruptive column rose to a great height and was accompanied by many bombs, some of them of great size, and a sort of coarse sand. The eruption seemed to issue from a long opening, in the form of a fissure, westward toward Mesa de Cocjarao. From the ground it was impossible to determine accurately 
the number of eruptive throats, but it appeared to have but one, large and somewhat elongated.

These inconsistent descriptions of the cone and its activity suggest that the eruption was quite variable.

It is likely the lava first issued from the surface vents sometime during this day. What apparently was lava was observed by Sra. Cuara at 11 o'clock. The great quantity of viscous bombs indicates that the rising lava column had already reached the surface, and the horseshoe shape of the cone suggests that the weak cone had been breached by flowing lava. Perhaps the rising lava column first reached the surface at midnight of February 20, when the first thunderous roars were heard in San Juan Parangaricutiro and incandescent rocks were hurled up with great force.

February 22.-Mr. C. Byron Valle, who flew over the volcano on the early morning of this day, reported that he distinctly saw two vents in the crater. A smaller one, at the base of the cone, did not have much explosive force; and lava appeared to issue from it. A larger vent showed only explosive activity. At the altitude of the plane, a distinct sulfurous odor was apparent, which Mr. Valle characterized as an odor similar to that about a smelter.

Celedonio Gutiérrez reported that at 3 a. m. a strong earthquake, stronger than any yet felt, shook the region intermittently for 7 or 8 minutes. This earthquake was felt over a wide area in Mexico, and its epicenter was determined to be off the coast near Acapulco, a spot of frequent heavy earthquakes. It therefore had no direct connection with Parícutin volcano.

Celedonio Gutiérrez in his diary described the activity for this day as follows:

Between 2 and 3 o'clock, after a terrible night occasioned by the tremendous noise of the volcano, strong earthquake shocks were felt, much greater than those felt before the birth of the volcano, which lasted for 8 seconds. After the earthquake the terrible explosions of the volcano began to diminish little by little, but did not cease. Although the thunderous noises were now not so strong, the eruption could not by any means be called silent. Ash fell in moderate quantity but, in contrast, bombs were ejected in great quantities and arose to an elevation of about 400-500 meters. The eruptive column that arose from the crater was not very large but it rose to an elevation of about 1,500 meters.

Photographs by Rufus C. Morrow (pl. 17B) taken on this day show an irregularly shaped cone, open to the east indicating breaching by flowing lava. The eruptive column was larger and denser than on the preceding day and contained a very large quantity of large bombs.

The already well advanced lava flow formed an irregular tongue that moved northeastward, emitting abundant white vapors from scattered fumaroles along an advancing flow front 6-8 meters high. At no later time did this or any other lava flow show such an abundance of 
vaporous emissions. This first lava flow we have called the Quitzocho flow. The shape and character of the eruptive column suggest numerous and violent explosions in the crater. Celedonio Gutierrez reported explosions each 10-12 seconds and that the ejected bombs assumed odd shapes, such as heads, hands, and feet, indicating that they were tatters of viscous lava.

February 23.-Eruptive activity continued with the abundant emission of bombs but with little ash. Ordónez reported the cone had a height of about 60 meters (pl. $18 B$ ) and that the lava advanced at a rate of 6-12 meters per hour.

February 24.-The activity of the crater continued in a regular fashion, with many bombs ejected but with little ash deposited on the fields. The lava flowed as a broad sheet, 700 meters long (Waitz, 1943) and advanced 5 meters per hour. A blanket of fragments and scoria covered the lava surface. The emission of vapors from the flow appeared greatly diminished and localized in fumaroles along the border of the flow (pl. 18A).

February 25.-The activity from the crater continued strongly but with somewhat better defined cauliflowers and thicker eruptive column, indicating somewhat increased activity. According to Waitz and Ramiro Robles, the explosive bursts averaged 16 per minute. These Ramiro Robles classified as 6 blasts, 9 explosions and 1 lightning discharge per minute. De la $O$ Carreño noted 20 explosions per minute and Teodoro Flores, 17 explosions per minute, 3 strong, 5 medium, 9 weak. Waitz reported that the breach, which had been kept clear by the constant flow of lava, now showed some signs of building up, indicating a cessation of flow from the vent, and that the advance of the lava was reduced to 3 meters per hour.

February 26.- On this day the beight of the cone was measured by Ramiro Robles (1943) as being 167 meters, with diameter of the base 730 meters and the diameter of the crater 90 meters across in a northsouth direction.

With the cessation of the lava flow the day before, the explosive activity in the crater had increased. A medium-sized black eruptive column arose majestically to a height of about 5,000 meters and terminated in a broad, white cumulus cloud. Some heavy explosive bursts ejected heavily laden clouds, the ash raining down upon the cone. At 2 p. m. a wet ash fell, the moisture probably due to the condensation of water vapor in the eruptive column. De la O Carreño reported that on many occasions the granules of ash were coated with a thin film of water.

Waitz, Ramiro Robles, and De la O Carreño distinguished three types of explosions: (1) blasts, (2) gaseous explosions, and (3) electrical discharges. The blasts were dull prolonged roars, like a jet 
produced by a piston in a steam engine, and yielded a vertical column of vapors heavily laden with ash, and carrying few bombs. The duration of these blasts varied, sometimes continuing for 6 minutes. When these blasts were numerous and prolonged, the explosive activity was cineritic. The gaseous explosions were violent expulsions of gas, with strong detonations, giving rise to cauliflowers. They were accompanied by innumerable quantities of bombs, hurled as high as 750 meters and thrown as far as $\mathbf{9 0 0}$ meters from the cone. The electrical discharges were vigorous detonations without eruptive phenomena. The visible flashes were short zigzag or arborescent bolts of lightning in the cineritic eruptive column.

Observers noted rapidly moving arcs of light in the eruptive column, followed by extremely heavy explosions. The arcs were described by De la $O$ Carreño as an intensely luminous yellow band and by Ramiro Robles as whitish yellow. Waitz identified these flashes as the "flashing arcs" of Perret (1912). These arcs were plainly visible in daylight.

By this day the lava flow had spread over a considerable area and formed a mass of irregular outline, the narrowest part 464 meters wide. It had a steep front, 5-11 meters high, and an irregular surface covered with a jumble of scoriaceous blocks of irregular shape. The lava front was loose rubble with sporadic exposures of torn and twisted lava. During the day, red incandescence could be seen in the crevasses of the lava front, and at night patches of bright incandescence marked the slowly advancing lobes of viscous lava. The rate of advance was now reduced to 1-2 meters per hour. As the flow advanced it frequently piled up a bank of soil along its foot. De la O Carreño (1943) gave the following statistics for the cone on this day: Elevation of the cone 167 meters, diameter of the base of the cone 615 meters, diameter across the crater 150 meters, slope of the cone $33^{\circ} 10^{\prime}$, approximate volume of the cone 19.5 million cubic meters, daily increment ( 5.9 days) 3.33 million cubic meters, explosions per minute 17 , increment of growth per explosion 136 cubic meters, volume of the lava flow 7 million cubic meters.

For the last 4 days of February, Robles Ramos (1943) gave the explosive activity as follows:

February 25. 16 explosions per minute: 6 blasts, 9 explosions, 1 electrical discharge. February 26. 18 explosions per minute: 9 blasts, 6 explosions, 3 electrical discharges.

February 27. 15 explosions per minute: 10 blasts, 4 explosions, 1 electrical discharge. February 28. 15 explosions per minute: 11 blasts, 4 explosions, occasional electrical discharge.

Many visitors came to the volcano during this period, attracted by the awesome spectacle of its explosive activity. At night the 
appearance of the volcano was particularly impressive. Innumerable incandescent bombs formed an almost continuously rising column of "fire" that ascended to 750 meters and then rained down upon the cone and the surrounding terrain. This incandescent column illuminated the area with a weird light, brighter than moonlight. The thunderous roars and rushing blasts, punctuated by the sharp crack of explosions, the thud of the bombs upon the flanks of the cone, the lightning discharges, the strong vibrations of the air and ground, held the spectator in awed fascination.

TABLE 3.-Summary of the first week of activity

\begin{tabular}{|c|c|c|c|c|}
\hline Date & Time & $\begin{array}{c}\text { Height of } \\
\text { cone } \\
\text { (in meters) }\end{array}$ & Lava activity & Crater activity \\
\hline $\begin{array}{l}22 \\
23 \\
24 \\
25 \\
26\end{array}$ & $\begin{array}{l}\text { 12:00 p. } \mathrm{m} \\
\text { 4:00 a. } \mathrm{m} \\
\text { 6:00 a. } \mathrm{m} \\
\text { 10:00 a. } \mathrm{m} \\
\text { 11:00 a. } \mathrm{m} \\
\text { 1:00 } \mathrm{a} . \mathrm{m} \\
\text { 3:00 p. } \mathrm{m} \\
\text { 2:00 p. } \mathrm{m} \\
\text { 4:00 p. } \mathrm{m}\end{array}$ & 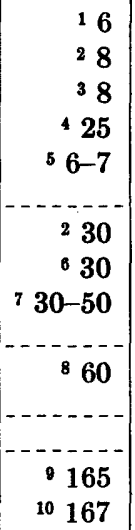 & \begin{tabular}{|} 
None \\
\hdashline do \\
Slow $(?)$ \\
None \\
do \\
do
\end{tabular} & $\begin{array}{c}\text { Cineritic, medium. } \\
\text { Do. } \\
\text { Do. } \\
\text { Do. } \\
\text { Do. } \\
\text { Bombs, heavy. } \\
\text { Do. } \\
\text { Do. } \\
\text { Do. } \\
\text { Do. } \\
\text { Do. } \\
\text { Mixed, heavy. } \\
\text { Do. } \\
\text { Do. } \\
\text { Do. }\end{array}$ \\
\hline
\end{tabular}

1 De la O Carreño, Alfonso, [quoting Jesús Mungia] (1943).

2 Robles Ramos, Ramiro (1943).

Pulido, Dionisio, personal communication.

4 Duarte, Mauricio, personal communication.

5 Waitz, Paul (1943).

- De la O Carreño, Alfonso, quoting Sr. Cuara (1943).

7 Treviño, Jorge, personal communication.

'Ordoñez, Ezequiel (1943).

- De la O Carreño (1943).

10 Robles Ramos, Ramiro (1943).

The first day of the new volcano saw the first surge of lava, which spread rapidly at first but gradually diminished its rate of advance until the seventh day when it stopped, and showed a tendency for the cone to heal its breach. On February 28, however, a second lava surge began, which cleared the breach. From the east the crater had the appearance of a low amphitheater with three active vents plainly visible. The lowest, and easternmost, was the smallest and the westernmost, the largest and highest; all were separated from each 
other by narrow septa joined to the inner crater walls. Usually these vents acted independently of each other, although they were sometimes active simultaneously.

The lava flowed from the amphitheater toward the east; but upon clearing the flanking wall of the cone, it turned north and moved down the slope as a scoria covered flow, covering the lands of Quitzocho.

Activity in the crater appears to have been rather erratic, varying from heavy cauliflower bursts to brief periods of inactivity. Explosions were reduced to 14 per minute, more than one-half of them being blasts.

The activity on February 28 has been described by Parker D. Trask (1943). The ejectamenta consisted of viscous lava bombs and coarse ash. The smoke column was relatively thin, consisting of isolated cauliflower bursts, strung together in a vertical column. The explosive bursts had the appearance of originating at the throat of the vent, or only a very short distance below. Explosions occurred at fairly regular intervals of about 4 seconds; sometimes explosions came in rapid succession, sometimes at intervals of 6 to 8 seconds. The explosions, in general, had their origin at the vent, although there were some in the ash cloud, 150 meters above the summit of the cone (lightning?). Large bombs were hurled to a height of 120 to 250 meters. The greater part of the material ejected at this stage consisted of bombs rather than of ash or sand. Each explosion threw bombs 600-900 meters into the air. Most of them fell upon the cone. The greatest distance from the cone that bombs were found was 1,000 meters from the center of the volcano. The bombs rose so high that many of them took 12 to 15 seconds to fall back to the crater rim, 500-1,000 meters below. They were roughly spherical, and their size ranged from that of "a nut to that of a house," but most of them ranged from 1 to 2 meters in diameter. The largest block Trask saw was 50 feet (15 meters) in diameter and was hurled 300 feet (90 meters) above the summit of the crater, that is, 850 feet (260 meters) above the vent. Almost all the bombs were entirely solid when they fell, for they did not change their form upon impact. The lava flowed at a rate of 3 feet ( 1 meter) per hour toward the west and spread laterally at a rate of 1 foot ( $1 / 3$ meter) per hour.

The activity of the volcano for the period February 25 to March 5 has been described by Teodoro Flores (1945), a translation of which is given below:

\section{THE CRATER}

On February 25 the crater of the volcano was situated toward the west border of the cone, with a form almost circular, whose dimension was estimated at 50 meters. In one aspect the cavity was similar to a funnel, with a slight sag in its 
rim that coincides in position with the northeast opening. It remained in this place and unchanged in form, other than an amplification of the crater each day, during the 26th and 27th.

On February 28 there began the development of a sag on the northwest ${ }^{10}$ side of the crater, resulting in an undulating form of the rim; at the same time one noted that the crater showed a movement, tending to shift to the east. The sag deepened during the night of the 28th; and on the following day, March 1, it was perfectly visible, measuring then about 30 meters deep. The side continued to slump during the day, and at $6 \mathrm{p}$. $\mathrm{m}$. viscous lava began to flow slowly from it along a wide and shallow break that had formed in the northwest ${ }^{11}$ flank of the cone and extended from the rim of the crater almost to the base of the volcano.

On March 2 the crater had deeply destroyed its northwest 12 wall; and the vent emitted great quantities of lava fragments toward the hollow left by the primitive vent, which rapidly filled. Furthermore, one could perceive clearly that a smaller vent had opened on the northeast side, from which gases and igneous materials escaped that were expelled either simultaneously or alternately with the other vent.

Examining the crater the same day from the northeast, in the direction of the opening of the cone, one could clearly distinguish the two vents, the eastern one being lower and smaller than the western; and it could be observed as well that both vents were localized very close to the highest point of the crater rim.

At 7:30 p. m. of the same day, both vents were very active; and a great quantity of lava flowed from a mound situated in the bottom of the northeast opening, advancing rapidly and invading the fields situated in front of the opening.

On March 3 the primitive vent and the break that had formed on the northwest ${ }^{13}$ slope of the cone were filled with igneous material, completely restoring this part of the rim of the crater to its previous outline. In the early morning of this day I had occasion to observe the projection of a column of incandescent lava in the form of an enormous fountain that issued from the medium slope of the volcano.

On March 4 the crater and its two vents presented an aspect very similar to that of the day before, but one noticed that they were a little lower in elevation. The vents were further lowered on the 5 th, with the result that the existence of another vent, clearly circular in form, could be perceived below the second vent (pl. 19A).

These changes are clearly shown in the illustrations that accompany Flores' report.

Explosions continued during the early days of March, sometimes so strongly that windows in San Juan Parangaricutiro rattled and doors swung open and shut with each explosion. Not only were the explosions heard in the town, but the blasts were distinctly felt. The eruptive activity continued to increase each day, but with rare brief intervals when the crater was silent. Activity and the shape of the cone remained essentially unchanged until March 18.

The Quitzocho flow issued directly from the explosive vent of the crater (pl. 20A). Its steep rubbly front advanced slowly, but little

10 This is an error; the true direction was northeast.

11 Idem.

12 Idem.

13 Idem. 
flowing lava was discernible. By the end of March it had spread over the entire Llano de Quitzocho to the western slope of Cerro de Jarátiro ridge.

The first advance of the Quitzocho flow, which began sometime during February 21, must have been rapid for it had already covered an extensive area when it was first recognized as a lava flow by Ordónez. It soon slackened its pace, however, the moving fronts advancing at rates varying from 1 to 2 meters per hour during its first week, later slowing to a rate of only several meters per day. At least two surges were recognizable, one terminating on February 26, the second beginning on February 28 and continuing until March 20.

The flow spread out in a great sheet with a front ranging from 6 to 15 meters high. The surface of the flow, after it came to complete rest, was undulating and very hummocky, sloping at a declivity of about $5^{\circ}$ from the foot of the cone to the north (pl. 19A). The elevation of some of the higher hummocks and ridges sometimes exceeded 5 meters. The eastern front of the flow was made up largely of a blanket of loose scoriaceous blocks and sandlike, granular, disintegrated lava, with scattered excrescences of massive fissured or twisted lava. The exposures of fractured lava frequently showed a bright incandescence in fissures and were the loci of fumaroles. The lava front facing Cerro de Jarátiro ridge had a somewhat different aspect. It was higher, reaching 15 meters in elevation, and extremely rugged, with huge blocks of torn or disintegrated lava rising in irregular pinnacles or forming cockscomb ridges. Fumarolic activity was particularly evident along this front. Two steeply conical peaks situated about 100 meters from the northeast base of the cone and rising about 7 meters above the general surface level were prominent features of the lava surface that caught one's eye. While having some resemblance to eruptive cones, the peaks showed no evidence of eruptive activity and probably resulted from pressure.

One of the features that distinguished the Quitzocho flow from later flows was the apparently high content of volatile constituents, as manifested by its abundant fumaroles. These fumaroles, however, were not generally distributed through the flow but localized along its peripheral portions (pl. 19B), usually along the front face at the crest of the front (pl. $21 B$ ) or in a zone less than 50 meters back from the crest. A few weak fumaroles at the summits of conical knolls were situated on the lava mesa itself.

On March 20 the cone began to heal its breach, indicating that the Quitzocho flow had ceased, and no further emissions of lava took place at this point. The flow already extravasated, however, continued to spread in all directions (pl. 20B). 
During the period of the Quitzocho flow the explosive activity was, in general, moderate (compared with later activity) although the accompanying noises were terrific. The ejected material consisted principally of bombs, largely semifluid in character, indicating that the explosions took place at or near the surface in a rising column of liquid lava. The cone grew rapidly, but the spread of ash over the surrounding terrain was comparatively slight.

The cone frequently changed its configuration during this period, owing in part to the varying activity or shifting of the three vents, but chiefly owing to the erratic flow of the lava. During pauses in the emission of lava, the wall of the volcano was built up by the accumulation of ejected bombs, only to be breached again by a new lava surge. The volcano showed alternatingly a conical form or a horseshoe shape. The original small mound, roughly conical, changed to a horseshoe shape with the first extravasation of lava. From February 21 to 25, it remained in this form, becoming cone shaped again for a brief period, February 26 to 27, only to be breached again on February 28. This breach was finally restored on March 20. The cone thereafter, as will appear later, attained such proportions that lava flows were no longer able to breach the cone completely.

\section{HGAVY CINGRITIC PHASE}

On March 18 the heavy bomb stage ceased; the crater passed into a very heavy cineritic phase which continued with some variation until early June. It was during this period that the greatest ash damage to the surrounding countryside was done. A huge column of ash and vapors boiled violently from the volcano in turbulent cauliflowers. Frequently they completely filled the crater from rim to rim, rising as a majestic eruptive column to a height of 6 kilometers or more.

The cineritic phase began on March 18 and continued all day with gradually increasing intensity until, in the night, the activity changed to a dense, billowing black eruptive column, and great "flames" or fountains of incandescent bombs rose to a considerable height. The number of heavy explosions increased; a deep roar seemed to come from the depths of the earth, and the ground shook under apparently ceaseless shocks. The fury of this night exceeded anything hitherto experienced at Parícutin and filled the observers with alarm, but by morning the violence diminished, and the noise changed to a continuous low rumble. The crater of the cone now appeared considerably enlarged, and a dense black, heavily ash-laden column rose in majestic volutes high into the atmosphere (pl. 21A). The winds, which at this season prevail from the west and southwest, carried the fine ash far to the east. Some ash had previously fallen on the region, but its distribution was very local; even in the immediate environs of the cone it 
was not more than a few centimeters thick. From March 18 to June 9, however, the ash fall was by far the heaviest experienced in the history of Paricutin. The ash cloud hung like a black pall over the region to the east and northeast so that the day was like dusk. A smoky haze dimmed the light of the sun as far east as Toluca, and fine ash fell on the rooftops and streets of Pátzcuaro, Morelia, and Zacapu, and even as far as the Bajio 250 kilometers away. The Carapan-Uruapan highway was covered with a thin mantle of ash, which swirled about and drifted into small windrows like dry snow. The fields and forests took on a dusty dark hue. Nearer the volcano the ash sifted through the trees of the forest with a gentle rustle like falling hail and blocked the Uruapan-Parícutin road. Figures passing but a few yards away appeared eerie and ghostlike in the ashy haze. Even at a distance of several kilometers, vesicular fragments as much as an inch across drifted down. On March 27, 15 centimeters of ash fell at a point 6 kilometers to the east of the cone. During early May the ash fall at Uruapan became so heavy that it was necessary to clear the roofs of the houses; it filled the patios to a depth of a few centimeters and all but halted motorcar traffic in streets. With the coming of the June rains, much of this ash was washed from the slopes of the hills, almost completely filling some of the small steep-walled arroyos, and in time the ash blanket over the fields and in the forest became so completely blended with the soil that it was no longer apparent over much of the area originally covered.

During April, May (pl. 22B), and early June, the eruption continued as a magnificent vertical column rising in volutes to a tremendous height. From angle measurements taken from Uruapan, we calculated its altitude as 6,000 meters above the crater. The black lower portion of the eruptive column (it appeared plum colored from a distance) passed through successively paler stages to a huge spreading white cumulus cloud. The prevailing winds carried the column toward the south, where it formed a dark curtain of settling ash. During this period the early morning hours were clear and bright; but as the rainy season approached, wisps of clouds began to appear about 9 o'clock, the first ones forming. in and about the drifting ash curtain (pl. 23A).

The rains began in May. Heavy showers accompanied by thunder frequently began about $2 \mathrm{p}$. $\mathrm{m}$. and continued intermittently, and commonly very locally, until 4 or $5 \mathrm{p}$. m., when the weather cleared again. During the rainy part of the day the condensed water vapor from the fumaroles of the Quitzocho lava flow increased. The rising wisps of vapor from the fumarole vents clung lazily to the slopes of the lava front and were drawn toward the cone from all directions. Towards nightfall, the vapors frequently collected as a blanket around 
the base of the cone. The first rains had little erosive effect upon the cone. Narrow radial lines of steam streaked the cone; or if the rain was heavy and driving, a whole sector of the cone gave off steam which disappeared very soon after the cessation of the downpour. Beneath the drifting ash column, a fall of mud was not infrequent.

During this period the surface winds were from the west, but the higher winds carried the ash curtain toward the south. Bombs of the larger sizes fell upon the cone or on the fields and in the forests for a radius of about 1,000 meters about the cone. Bombs found in the woods some distance from the cone were frequently as much as a meter or more in diameter. They fell in such numbers that it was impossible to approach the base of the volcano. The temperature of the air was distinctly cooler in the falling ash or lapilli beyond the zone of bombs than outside an ash fall. Small lapilli were distinctly cold to the touch. It was not until the falling lapilli reached about 3 centimeters in size that they showed perceptible warmth. The bombs showed no incandescence on the surface during the daytime, but were bright red or orange in cracks or when broken open. Although incandescent inside, the surface temperature of one small bomb that fell close to us was $202^{\circ} \mathrm{C}$ immediately after its flight. In the area south of the cone, domes of ash $1 \frac{132}{2}$ meters high collected beneath the wide, spreading oak trees, their branches intercepting much ash and finer lapilli. On May 24 we went to Taco's house, about 1/2/2 kilometers south of the cone, and found only the ridgepole above the ash, indicating that during 2 months of ash activity the depth of accumulated material at this place had reached about 2 meters. All through the forest, the pine trees were buried above their lower branches (pl. $34 A$ ).

At about 8 p. m., March 18, the noises of the crater began to diminish; at the same time the eruptive column increased and became heavily laden with ash. The cone was now so silent that the inhabitants of the region believed that the volcano would cease or change to some new activity. Not a visible bomb rose about the crater rim. Now a second vent opened on the south side of the cone, and lava flowed in two streams toward the southwest. The area lying between the cone and lowest slopes of Cerros de Tancítaro had many cañadas; small basins, and small mesas; and the new flow filled some of the larger basins. The flow was short and was soon covered and hidden by heavy ash falls. Its lava differed from that of the Quitzocho flow in being more blocky and more heavily oxidized, red or cinnamon. Unfortunately, no record was made of its particular characteristics nor the extent of its fumarole emissions. This flow we have called the Pastoriu flow.

During most of April 17, the heavy ash column continued as previously, but at $3: 30 \mathrm{p}$. m. activity again ceased, and the eruptive column $3386690-55-4$ 
died down completely About a quarter of an hour later eruptive activity resumed, but with much less ash and many bombs, accompanied by deep grating roars. With this change in explosive activity, a second lava flow broke out from the same vent from which the Pastoriu flow had issued; the new flow carried with it a large portion of the south side of the cone, which formed a ridge, 60 or more meters high, moving slowly toward the southwest The ridge broke into two wings. The eastern segment, swinging on a pivot at its contact with the cone, appeared to be an intact section of the cone. The western segment moved out farther than the eastern wing and was more disturbed. These two segments and the concave slope of the broken cone formed an amphitheater. The lava flow, issuing from the base of the cone, passed between the two wings of the break and flowed down a small cañada, following the trail from Cerro de Chanamuro to Parícutin. It continued as a small flow about 20 meters wide, followed the southwest and west base of the cone, and spread out over the Llano de Quitzocho to the now immobile Quitzocho flow. Then spreading westward, it advanced to the narrow valley separating the Cerro de Jarátiro from the lower slopes of Cerro de Canicjuata. This lava front still showed some slight advance on March 23 but ceased almost immediately after. The junction of the Quitzocho lava and this flow formed a rugged $V$-shaped valley extending from the foot of Cerro de Jarátiro to the base of the cone, and along this junction of the two flows fumarolic activity was particularly abundant. The front of the flow was unusually asperous, contrasting distinctly with the already ash-covered Quitzocho flow; jagged pinnacles of tilted lava blocks projecting from a front of blocky rubble gave it a particularly rugged appearance. This flow was typical block lava (pl. 21B). We have called it the Mesa del Corral flow.

With the outbreak of the Mesa del Corral flow, the crater resumed its heavy cineritic stage. The heavy ash falls of this period soon repaired the break of the cone and covered the flow, but its effect was evident for some months afterward as a high half-domelike hump on the southwest flank of the cone. After a few days of cineritic activity an inner or "daughter" cone, called the Ombligo (navel) by the natives, showed itself above the crater rim, eventually rising to an elevation of about 30 meters above the old crater edge. This inner cone continued to grow and finally merged with the main cone, the last perceptible trace of which was a narrow bench that marked the old crater rim (pl. 22A).

From April 20 to June 8 the eruptive activity, while continuing to throw out great quantities of bombs and ash, took place with comparatively little noise, usually a recurrent roll like heavy surf upon a rocky coast, with occasional deep thunderous explosions. Although 
more variable, the crater continued in full activity, with a heavily ash-charged column rising in volutes to a great height, showering bombs on the cone and its vicinity and ash over a wide area of fields and forest. It became necessary for the villagers of San Juan Parangaricutiro to clean the roofs of their houses every 2 or 3 days to prevent collapse.

It was during this period, too, that strong winds sometimes raised a dense dust that obscured the sun, which together with the heavy ash-fall made it necessary to use lamps in San Juan Parangaricutiro during the daytime; and in Uruapan, 25 kilometers to the east, street lights were turned on, and motorcars found it necessary to proceed with headlights aglow.

In early June heavy wet ash fell that bent and broke large branches on the trees as far as 5 kilometers to the north. The noise of breaking trees and branches was described as resembling gunfire during a skirmish in war. Many young pine trees not broken were bent double to form arches of ash.

\section{RECURRING FLOWS}

In early June Parícutin entered into a new and violent phase of activity characterized by intermittent but very violent explosive activity from the crater, by various lava flows, and by the rafting of the north side of the cone on three occasions. From early June into August the volcano showed its most varied and spectacular activity. The variety is described from notes taken during our stay from June 9 to 19 .

June 9.-At Uruapan this day began beautifully and clearly after the deluge of rain of the night before that cleared the atmosphere of volcanic dust. The "smoke" plume of Parícutin was sharply visible from Uruapan, rising several miles vertically, with a long dark curtain of ash carried to the south by the winds. At $9 \mathrm{a} . \mathrm{m}$. clouds began to gather in all directions, as is usual in this region at this time of the year, but especially about and below the long dust curtain. Compared with the white vapor clouds, the appearance of the eruptive column was pinkish brown.

Upon approaching San Juan Parangaricutiro at 2 p. m., we could see through a gap in the encircling hills the cone of Paricutin and its huge billowing column of ash. At 3 p. m., while we were awaiting our horses and mules, a casual glance toward the volcano showed a remarkable change, a rather sudden and marked decrease of the smoke to a thin languid column that shrunk perceptibly as we watched, as if a valve had been closed and the volcano was subsiding to rest. A half hour later there remained but a thin wisp of pale vapor and an occasional quiet burst of large bombs with little ash; and an un- 
natural calm settled over the cone. The change was so unexpected and so unusual that we all thought the volcano was dying and many of us gathered with the Presidente Municipal for a celebration.

We arrived at the camp on Cerro de Jarátiro about 4 p. m. The Quitzocho flow was now completely covered with ash, except for the peaks and crags that projected above the surface or faced the edge of the flow, and the numerous fumaroles along the lava front lazily gave off their usual white or bluish fumes.

The bursts from the crater threw out a scattering of large viscous bombs, without ash or much visible vapors, accompanied by a deep throaty grumble. This rather tranquil state did not last long. Soon the activity began to increase, gradually, almost imperceptibly, until at $9 \mathrm{p} . \mathrm{m}$. the bursts followed each other in rapid succession. Strong explosive bursts now came each $1 / 2-4$ seconds, hurling large blocks, some to a height of more than 600 meters (12 seconds to fall). These bombs showed many irregular and changing shapes; rods, clubs, and macelike projectiles, some like boomerangs or T's and a surprising number like birds soaring through the air, all indicative of the viscous state of the bombs. Upon falling on the slopes of the cone, these bombs broke into cascading fragments or rolled down the slope like pinwheels, casting incandescent fragments in leaping arcs before them. The noise of the large explosions was tremendous, and one could feel the blast of air at the camp $1 \frac{1}{2}$ kilometers away. Occasional overwhelming explosions gave advance notice by a vivid pink suffusion of the rising column, followed by a striking arc of yellow light (flashing arcs) that shot up into the sky from the crater. These were followed by bursts of huge irregular masses of lava, incandescent orange, which, upon falling on the slopes of the cone, made fantastic cascades of glowing rock. Six seconds after the explosion the sound wave reached us, an overpowering roar, reverberating around the hills like the roll of thunder.

At midnight there was a vivid electrical storm south of the region in the area of heavy dust fall. Early in the evening I noticed a slight offset in the summit line of the cone, as if a segment had slumped slightly. By midnight this straight displacement had become a distinct sag (fig. 112).

June 10.-The indescribable noise and confusion continued until 2 a. $\mathrm{m}$. At 2:10 the tremendous roar suddenly ceased. At 2:11 a. m. there was one last tremendous blast; then quiet. I [Foshag] went to the door of the cabin but could see nothing more than a large dust cloud. When this began to clear, I could perceive an occasional incandescent bomb rolling down the indistinctly visible cone. When the dust had sufficiently cleared after this last explosion, the crest of 


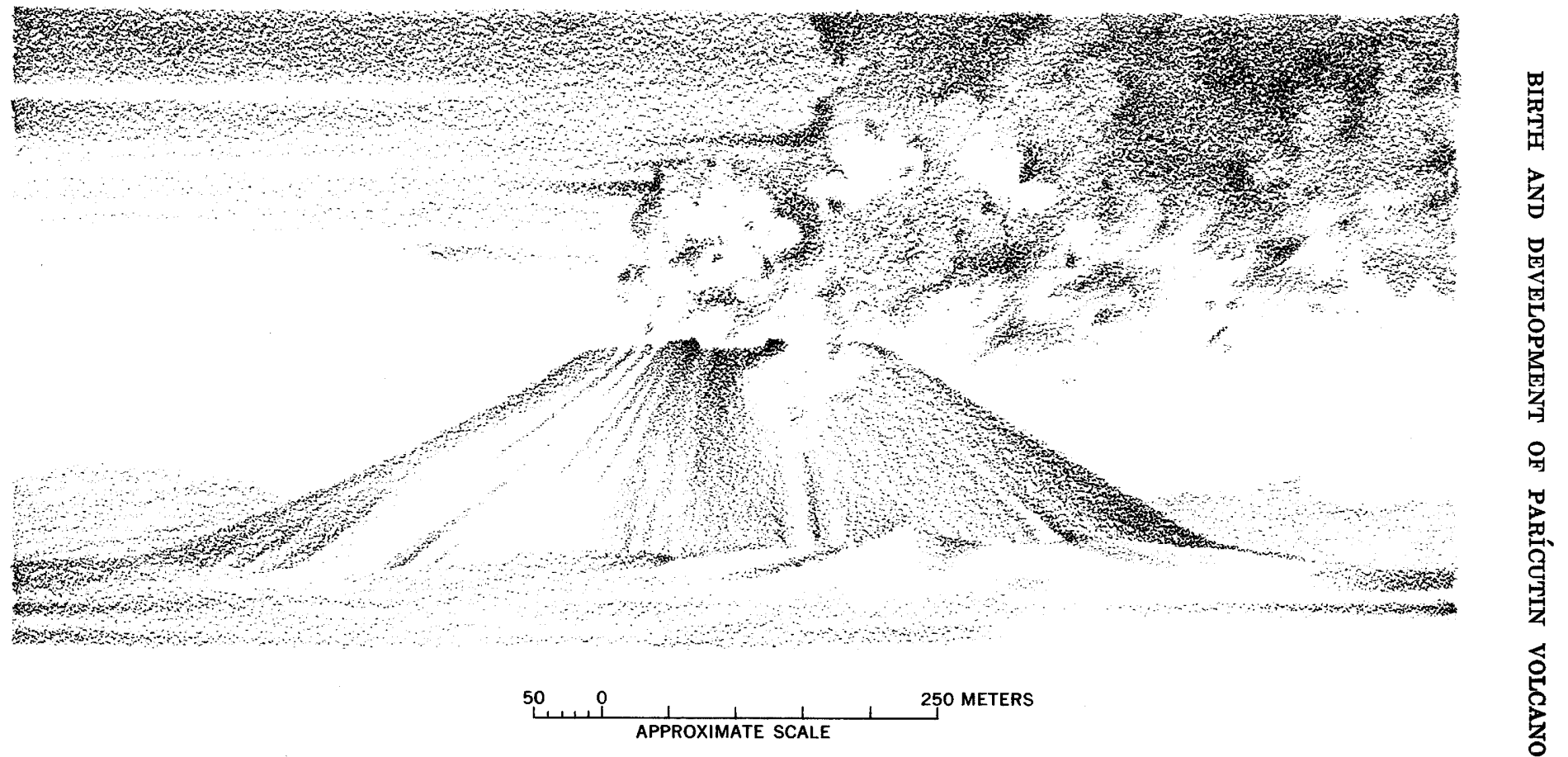

FrGURE 112.-Paricutin volcano on June 9, 1943, at 9 p. m., showing the cone, complete except for a slight slump in the north crater rim. Ash-covered Quitzocho flow in the foreground. 
the cone was no longer straight but saddle shaped, but it remained for morning to reveal what had taken place.

Soon after, the crater resumed its activity, now without perceptible noise but with a beautiful column of rising incandescent bombs, one burst following another in rapid succession; and thus it continued until daybreak.

Daylight revealed a huge break in the cone (fig. 113). A segment embracing about one-quarter of its perimeter had moved out (carried out by lava we learned later). The side walls of the break were steep, and the slumped portion lay in two long terraces at the base of the cone. The volcano was now very quiet, with only rare bursts of bombs but with a heavy, slowly rising eruptive column.

The summit of the lower of the two main terraces sloped down from the east end of the break at a $5^{\circ}$ angle to the west end, and its front showed a regular wall with slopes at the angle of repose (about $32^{\circ}$ ). This lower terrace advanced very slowly toward the north, its movement dislocating rocks on the slope, which rolled down raising a fine pinkish dust.

The western extremity of this lower terrace had a reddish oxidized color, and the frequent falls of rock raised plumes of pinkish ash. At 11 a. $\mathrm{m}$. incandescent moving lava appeared at this point. For the first time in the life of the volcano, the eruptive activity of the crater had so diminished that one could reach the base of the cone with reasonable safety, and we were able to watch the lava at close hand. The lava front, although incandescent in the crevices and gashes and in the blocks that spalled off, showed no liquid lava. It advanced at a rate of 30 meters per hour as an apparently solid wall of rock and rubble. Hugh incandescent masses were dislodged and rolled to the foot of the flow, and there was a continuous disintegration and streaming of incandescent pebblelike fragments or sand down the seamy lava front. Blocks on the lava front disintegrated with a continuous crackle, to which was added the tinkle of sliding scoria. The hottest incandescent lava was orange red. No visible fumes were given off, and there was no perceptible odor. The flow carried a cover of ash, the surface of which was wet from the rains and steamed from the heat below.

All during the day the crater was quiet with only rare explosive bursts that yielded a huge eruptive column rising silently to a height of about 5,000 meters.

At about 7:40 p. m. a thin white column of vapors suddenly appeared near the northwest base of the cone. This column was larger than the fumaroles and within the main part of the Quitzocho flow where no fumaroles were situated. Within a minute or two the base of the vapor column became suffused a deep pink, indicating a reflection from 


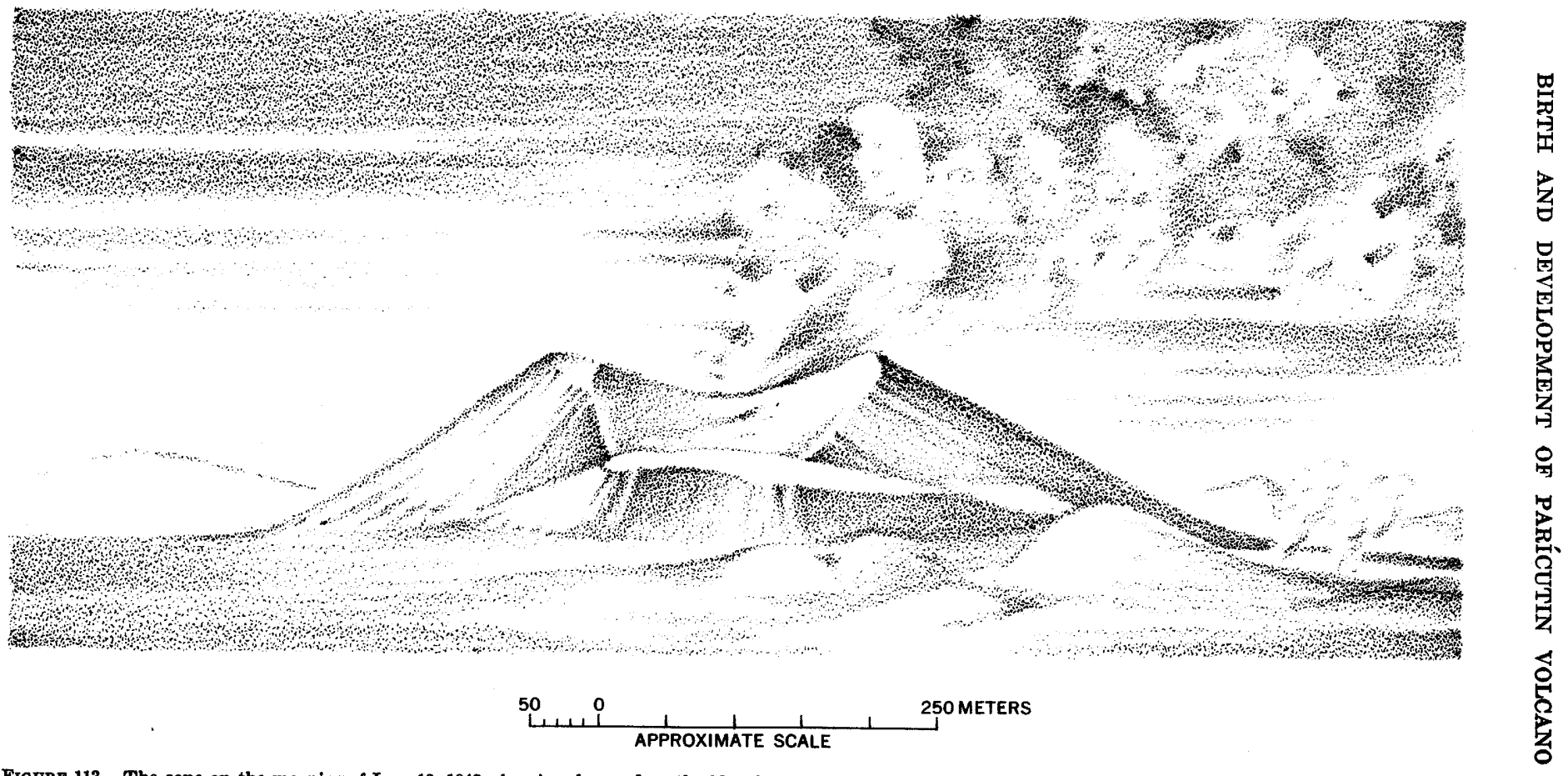

FigURE 113.-The cone on the morning of June 10, 1943, showing slumped north side, the slumped block as a high sloping terrace, and lava flow to the right. The knoll to the right indicates the beginning of the Quitzocho ridge. 
incandescent lava, which rapidly increased in intensity. We hastened to the spot, crossing over a newly formed ridge of ash, furrowed and seamed by small crevasses (pl. 29A). This ridge, which was later to show striking changes, we have called the Quitzocho ridge. Beyond we found a new low cliff of lava, with incandescent patches, slowly advancing and disintegrating. Huge incandescent blocks broke from the front and rolled to the foot; and small incandescent fragments, hardly distinguishable from liquid lava, streamed down its face.

About 15 minutes after our arrival, a spot on the lava front became more incandescent (orange yellow) and began to work like slowly rising dough. In one-half a minute the lava at this spot began to flow and spread, and within 5 minutes a front 5 meters across flowed down the slope like molasses. This flow, moving between the newly formed ash ridge and a knoll, upon which we had taken stance, moved so rapidly that we feared we might be cut off. From the surface of the flow small incandescent fragments of lava were sometimes blown up, with a hiss of escaping gases; or small whirlwinds formed, spiraling so rapidly as to produce a whistling.

By $10 \mathrm{p} . \mathrm{m}$. the flow had spread over a large area, with a front 100 meters or more across. By now its advance had slowed greatly, and its surface was already black, except for the numerous cracks that furrowed it, when a second surge came, overriding the first and emitting copious white fumes tinted pink or yellow by reflection from the glowing lava.

During this activity of the lava, the crater gave off a billowing black eruptive column but with few explosions, much as it had done during the entire day. Through the night, however, activity in the crater increased, with spasmodic strong explosions.

Upon returning toward our camp we found the newly formed ridge of ash higher and more deeply furrowed. With considerable trepidation we climbed an eminence and saw at our feet the apparent source of the lava, an incandescent stream, perhaps 20 meters wide, moving noiselessly along, dappled with moving blocks of congealed black lava. Its apparent source was the foot of the collapsed terrace, from which it appeared to flow quietly and without disturbance.

June 11.- The morning was fairly clear, but clouds formed early with rain at noon. An eruptive column of billowing black ash decreased in volume until at $2 \mathrm{p}$. $\mathrm{m}$. it showed little ash, sometimes none; and the opposite side of the crater could be seen through the newly formed gap in the north wall. The accompanying noise was an almost continuous growl. Fairly large blocks were hurled up, but none rose higher than the old crater rim.

In midafternoon there were two blasts from the crater about a second apart. One from the center of the crater ejected incandescent 
bombs, the second, near the west rim, dense black ash (the first indication we have had that the crater sometimes had more than one vent).

Activity from the crater slowly increased during the afternoon. The flow of last night had practically ceased, and only a few short segments of the front showed slight advance. The flow extended from the west foot of the lower terrace, passed between the foot of the cone and the newly formed ridge, and covered a wide area between the cone and Cerro de Canicjuata.

June 12.-The morning was heavily overcast, and rain drizzled down. From a station northeast of the cone, two eruptive columns were distinguishable - the one from the western part of the crater gave off dense gray smoke; the second, near the northeast rim, yielded some bombs and less ash.

At 2:30 p. m. the rain ceased somewhat; and when we went out to place some collecting tubes in the fumaroles, we found the new ridge now increased to about 30 meters in height and, beyond the ridge, new lava flowing down Parícutin Arroyo in the direction of Parícutin village. This already well-advanced lava flow had its apparent source beneath the ash near the vent of yesterday's flow. As the flow moved across ash-covered fields to the edge of Parícutin Arroyo, its front became steeper until it was entirely free of the congealed clinkers with which most flows are covered, exposing the actual moving incandescent lava below. Its advance took place as slowly bulging lobes, which gave the entire moving front a gross botryoidal surface, bulging and cracking with an everchanging surface. Such clinkers as formed rolled down this front to the arroyo below. As the bulges reached a certain degree of protuberance, they tore off and rolled down the arroyo slope as viscous masses. Most prominent was a basal bulge, slowly turning under and incorporating within itself the accumulated clinkers at the base of the flow. Sparse bluish fumes arose from the lava, but the only sound was the tinkle of moving clinkers. The advancing front was $4-5$ meters high. This flow we have called the Parícutin flow.

During the afternoon, activity from the crater subsided until there was little smoke from the cone. One could now clearly discern a large crater to the north, separated by a high, steep medial septum from another to the south. The north crater was entirely inactive, but the south vent was in active eruption. During the night, this south vent yielded a fine pyrotechnical display, hurling incandescent bombs 1,000 meters into the air with frequent bursts of black ash. This eruption was noiseless except for the swish of the bombs through the air and their dull thud upon the slopes of the cone. 
Throughout the night we noticed new glowing spots in the old ashcovered Quitzocho lava, which proved to be not new cracks but the rejuvenation of older fissures.

June 13.-The day was cloudy and rainy when we awoke at daybreak to a tremendous grating roar that continued without interruption, except for very rare periods of one-half minute of complete silence. At our camp 1 1 $\frac{1}{2}$ kilometers away the vibrations from this roar were perceptible and sometimes were even strong. From the south crater a small column of smoke and small bombs shot up in a swift and continuous stream, a veritable geyser of fire, but the north vent was inactive.

Don Felipe Cuara came on horseback in some agitation to tell us that Parícutin village was threatened by lava (the Parícutin flow). On arriving there, we found the lava of yesterday had advanced well beyond the limits of the Mesa del Corral flow and was moving forward at a rate of 25 meters per hour but spreading laterally at only $2 \frac{1}{2}$ meters per hour. With Parícutin village located on a low ridge, we concluded that the lateral push of the lava would not be sufficient to cover more than perhaps a few of the lower houses. We counselled, however, the people to evacuate the town, because their fields were already beyond use from the heavy cover of ash and there seemed no surcease from the continuing ash falls. The Mexican Government had offered them facilities to evacuate their village and to settle on new lands in unaffected areas. This was sad advice to a people so deeply attached to their soil, and many were loath to accept it.

June 14.-During the morning hours a variety of noises came from the crater. Sometimes the sounds were roars, and occasionally a tremendous explosive burst, sometimes a sound like the sigh of a high wind in the pine trees. The noises came chiefly from the south vent, but there were erratic bursts from the north crater.

In the early morning a new lava flow burst out on the upper slopes of the cone above the upper terrace, between a resistant pyramidal remnant of the cone and the eastern wall of the break. Its point of origin was about 75 meters below the lower lip of the north crater, and the lava flowed as a cascade down the terraced slopes to the northeast base of the cone and beyond (fig. 114). This flow we have called the Lagunita flow, because it invaded and covered the lands of La Lagunita. The lava emitted bluish fumes, sometimes tinged a brownish yellow. The flow advanced at a rate of 15 meters per hour into the dead pine forest.

The north crater gave off faint bluish or brownish fumes; at rare intervals, bursts of incandescent bombs of black ash. The south crater emitted a continuous eruptive column accompanied by occasional roars or puffs similar to a starting locomotive. 


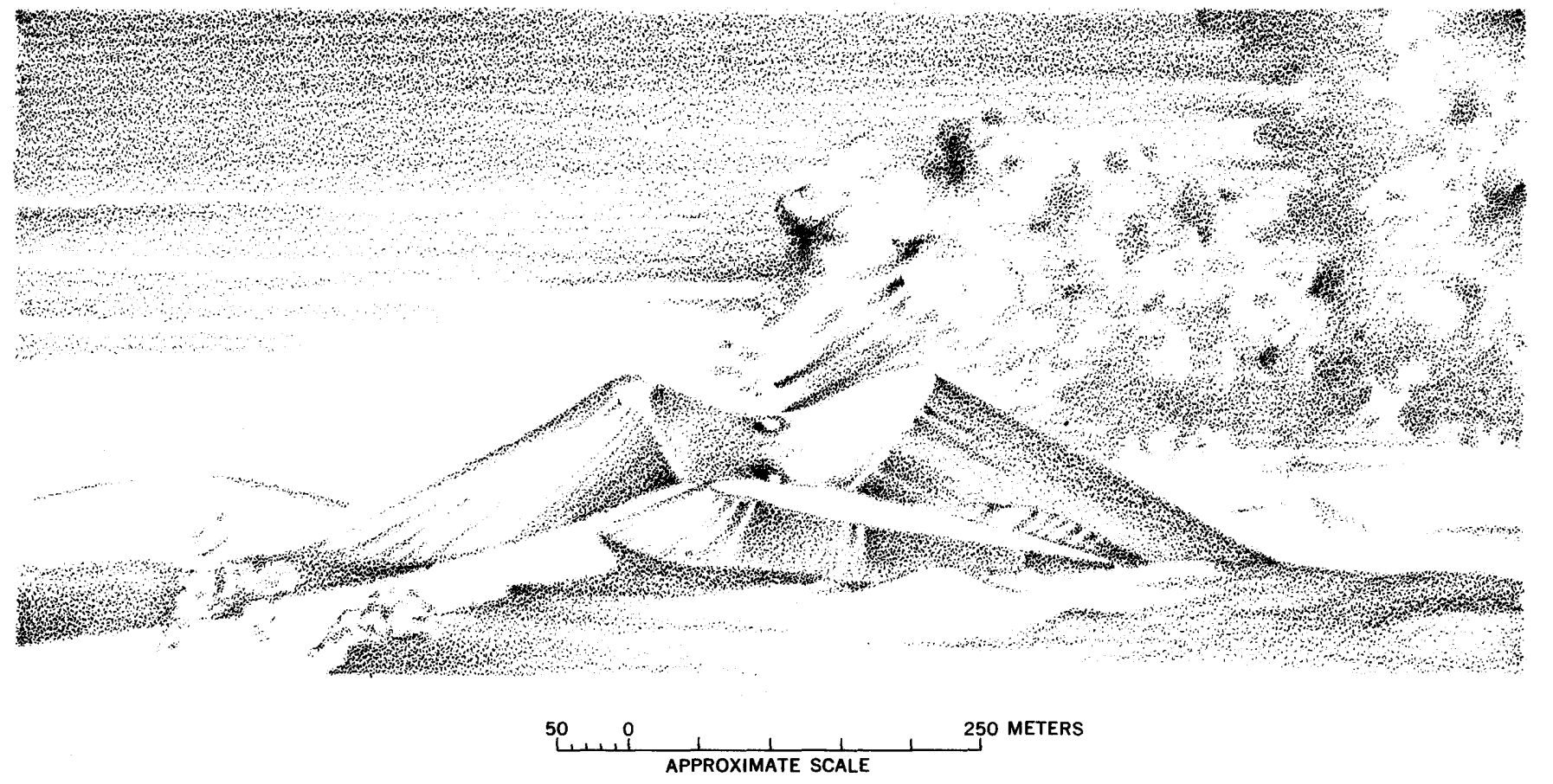

FIGURE 114.-The cone on the morning of June 14, 1943, showing the break in the north slope of the cone, with the north crater vent; below it the lava vent above the slumped block; the lava flow is toward the left and the smooth Quitzocho ridge to the right. 
We went to Parícutin village at $4 \mathrm{p}$. $\mathrm{m}$. and found the lava still advancing. The front progressed at a rate of 21 meters per hour, and its lateral push had carried it within 80 meters of the first house of the village. Many houses were being dismantled, and trucks had already arrived to evacuate the people.

At $6 \mathrm{p} . \mathrm{m}$. the eruptive column rose slowly from the cone with a low sound like a beating surf. The locomotivelike puffs continued and came, perhaps, from the north vent. With darkness the incandescent cascade of the lava, flowing down the cone, produced a magnificent sight.

June 15.- In the morning we went to Parícutin village. The lava flow had slowed to a low speed, greater toward the northwest in the direction of San Juan Parangaricutiro, much less laterally. The west side of the flow was then about 20 meters from the first house in the village, and the inhabitants had placed an additional cross before the dwelling to ward off the danger of its destruction. A few weak fumaroles had already formed in the flow, indicating that it was now practically at rest; and the fumaroles were beginning to yield thin white, yellow, or orange sublimates.

In the afternoon we went to the Lagunita flow, which moved down the terraces from the upper vent. This had spread in a sheet between the Quitzocho flow and the low hills bordering the eastern edge of the valley. The Lagunita flow was thicker than the Parícutin flow and advanced more slowly, 5-10 meters per hour. It was viscous, bulging here and there as the moving lava broke through the front of advancing rubble. There was no odor, few fumes, and little noise, except for the tinkle of sliding clinkers. The flow followed the general slope of the terrain but moved over low slopes of hummocky ground and low knolls.

At night the volcano offered a magnificent sight $-a$ bright incandescent eruptive column showered bombs upon the cone, and the two brilliant rivers of orange lava cascaded from the vent to the base of the cone and flowed to the lava field in the valley, where myriad lights looked like a city viewed from a distant hill.

At $9: 30 \mathrm{p}$. m. the lava vent began to spurt with a noise like a starting locomotive. Fountains of lava, estimated at 5 meters high, appeared at the vent, hurling viscous masses to a height of 50 meters. With this increased activity in the lava vent, the north crater resumed weak activity, throwing out small bombs and glowing ash with quantities of black smoke or thin wisps of vapor. The north crater rapidly filled with ejectamenta from the south vent. Most of the bombs fell to the west, and the western part of the break in the cone was rapidly being repaired, while the east wall of the break was still much in its original condition. 
June 16.-In the early morning the north vent threw out much ash and a heavy fall of bombs, and the south crater was steadily active, continuing so until $11 \mathrm{a} . \mathrm{m}$. when the north crater ceased its activity and then showed little action during the remainder of the day. The east flow continued its slow advance. Its front was 5 meters high. The lava seemed to show less incandescence, and the flow appeared to be subsiding.

June 1\%.-The day was clear, and white fleecy clouds were scattered in the sky. The north crater was now filled by ejectamenta from the south vent. The day began with heavy explosions from the south vent, hurling out huge bombs but little ash. To the west of the main eruptive column, a plume of vapors lazily rose as if it came from a second vent in the south crater. At 7:45 a. m. the heavy explosions ceased, and for $2 \%$ hours there was a quitely rising eruptive column with intermittent blasts hurling up large irregular masses of lava.

At 10:20 a. m. sudden jets of lava appeared near what had been the summit of the pyramidal block and 25 meters above the earlier lava vent, which had ceased flowing (fig. 115). This new lava moved rapidly, like a red tongue, down the $40^{\circ}$ slope and dropped about 100 meters to the level of the upper terrace. A second surge of lava almost immediately followed the first. Twenty minutes later a tremendous explosion from the new vent hurled huge molten masses of lava into a fan-shaped burst, and the wall above the new vent began to crumple slowly and slump, exposing a red glow, apparently of incandescent ash and rock. It appeared that the gradual attrition of the continual explosive bursts had exposed the interior of the cone very close to the conduit of the north vent. The flow of lava rapidly increased and 25 minutes after its first outbreak was 10 meters wide and advanced rapidly down the steep slope.

During this lava activity the south vent emitted a heavy eruptive column, rising silently or with a low sound like surf. Now, however, the south vent and the newly formed throat entered into a spasmodic but strong series of explosions, with violent blasts from 15 minutes to an hour apart, both vents hurling out huge masses of viscous lava. Sometime during this period of violent explosive activity, the lava surge ceased rising in the conduit, and the flow abated. At 2:04 p. m. another new vent broke forth, without noise, near the locus of the first. Soon after, the lower lip of the north crater began to show some incandescence, as if liquid lava was oozing through the wall, which was immediately followed by a tremendous cascade of incandescent lava flowing down the west side of the break. This surge of lava lasted only 3 minutes but was followed 5 minutes later by a lesser and slower surge that appeared to be more viscous, tearing into huge blocks which rolled down the steep slope as it advanced. This was in turn followed 


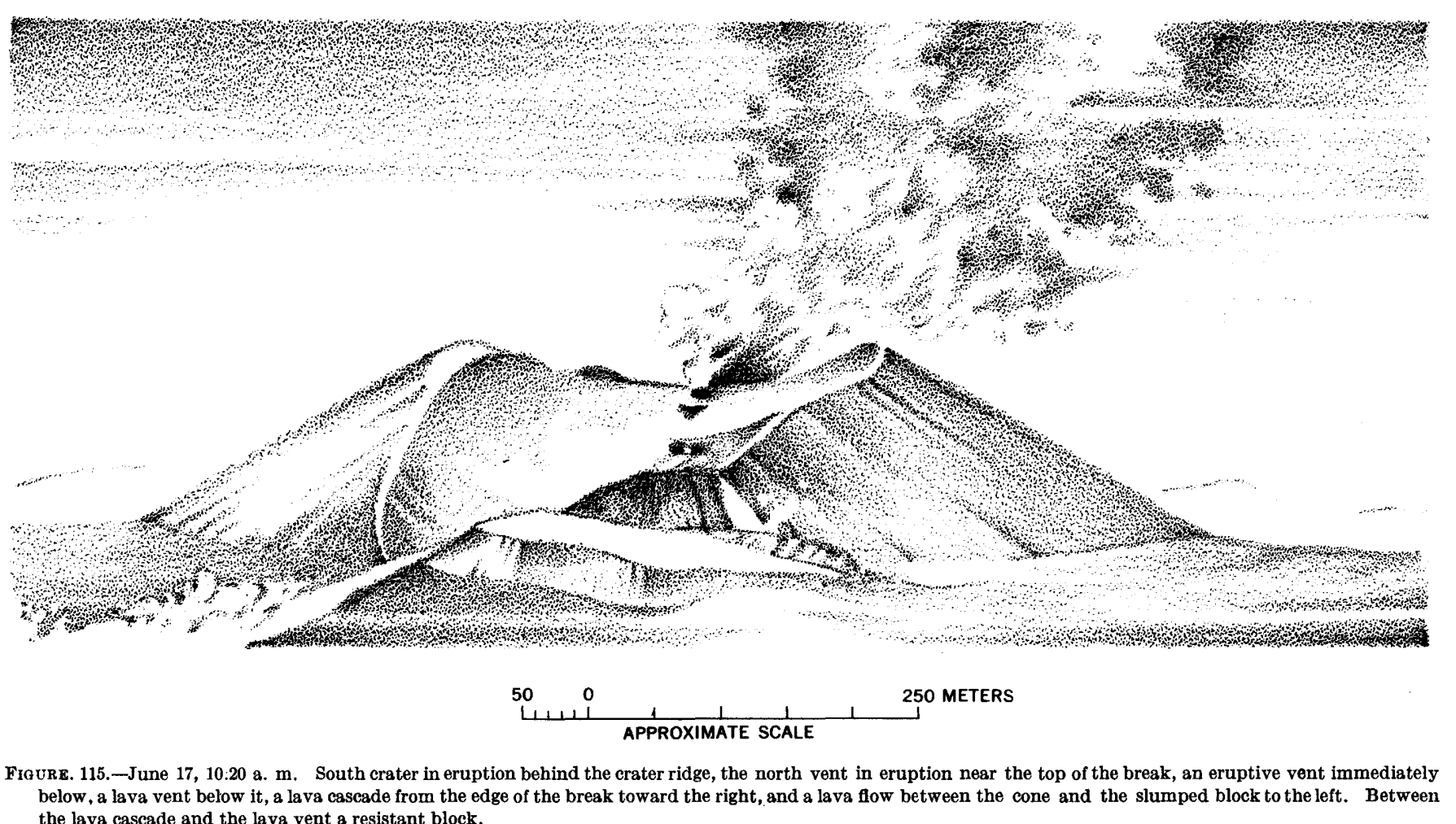
the lava cascade and the lava vent a resistant block. 
by a tremendous surge, which rolled slowly over and over. During the period of lava surges, the east flow appeared dormant and the south crater much reduced in activity.

The cone showed a cirquelike wall behind the Lagunita vent. The wall behind the new vent changed to a similar cirque, about 50 meters high, at the summit of which began to appear, through attrition, a low black cliff, with incandescent spots and occasional streamlets of either liquid lava or incandescent fragments. This cliff was obviously more compact than the loose ash and bombs of the cone and was perhaps the inner welded surface of the old north crater.

At 4:49 p. m. a new surge of lava from the new vent was accompanied by a heavy explosive burst.

At 6:27 p. m., blowing like a bessemer converter, the old north crater reopened immediately above the incandescent cliff as a vent about 3 meters across with the continuous emission of smoke and the streaming of incandescent bombs. At the same time, the lava flow increased, and the whole front of the advancing tongue tore off and rolled down the steep slope like a huge red snowball. The lava now flowed continuously with greatly augmenting surges at about hourly intervals. With each increased surge tremendous masses of viscous lava tore from the advancing stream and rolled down the slope. During this lava activity, the action of the south crater was slow and steady with a continuous sound like beating surf. Explosive activity from the north crater consisted of a rare heavy burst with much black ash and "flames" streaming incandescent ash.

June 18.-In the early morning hours explosions occurred in both the north and south vents simultaneously at regular intervals, suggesting that the two crater vents were connected. Lava flowed in a broad stream down the slope of the upper terrace and in a broad cascade over the lower terrace and spread in a broad sheet over Llano de Quitzocho and La Lagunita. The lava was not the rough and hummocky flow of the Quitzocho lava but a broad flat sheet, very gently convex in cross section and covered with a characteristic blanket of clinkers. Unlike the Quitzocho flow it had only a few weak fumaroles.

During the morning the south crater gave off a continuous heavy billowing column, while the lower lava vent gave off occasional bursts of black ash, at times with great violence (fig. 116). The lava flowed intermittently, with occasional surges. At 12:25 p. m. a huge lava front advanced slowly toward the east from a point below the lava vent, spreading out to a front about 50 meters wide and then advancing more rapidly, throwing out several lobes down the steep slope of the upper terrace. In the 15 minutes it took to reach the base of the cone, the lobes had already congealed and remained motionless on the 


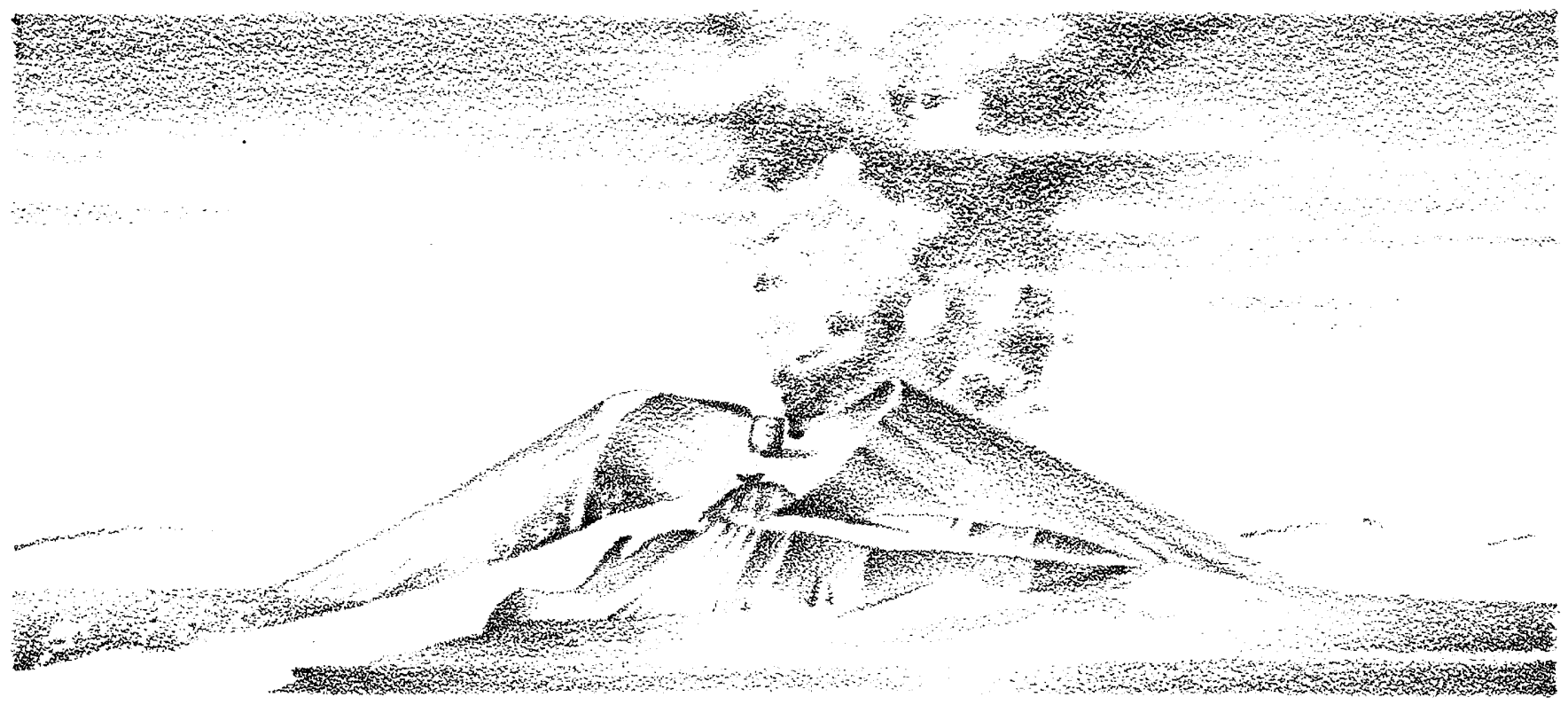

FIGURE 116.-June 18, 1943, 11:20 a. m. Eruption from south vent; eruption from north vent in upper part of break, resistant ridge on crater rim and resistant plug in the break. Below the resistant plug the lava vent, and the lava flow toward the left. 
steep slope of the terrace, an indication of how rapidly a flow can completely congeal, even on very steep slopes.

At 12:50 p. m. activity in the south crater and the lava vent spasmodically increased in intensity. The south-crater activity increased noiselessly.

During the morning, a resistant plug remained prominently defined against the smooth ash walls of the concave break. At 11:20 a. m. two earlike protuberances gave it the appearance of an owl, but by noon it had already begun to gradually disintegrate. At the time of the heavy eruption of late morning and early afternoon, it slowly diminished in size. At $12: 28 \mathrm{p}$. m. a new vent appeared where the plug had been, its orifice perhaps 10-15 meters across, with what appeared to be an incandescent rim or aureole. This vent was about 10 meters above the previous one, which was in violent eruption only a few minutes before. From this new vent eruptive material rushed with tremendous velocity, like a huge blow torch, roaring continually with a harsh grating, reverberating roar.

The activity of the volcano had now reached a tremendous intensity. The south crater threw out great masses of rock and a heavy column of ash, and there was spasmodic heavy activity from the lava vent. One could feel the percussions of the eruptive blasts at the camp, and the ground was in frequent trepidation. Surges of lava flowed from the vent. The north wall of the south crater became fissured and began to show distinct attrition and lowering of its rim.

June 19.-The north slope was now a smooth concave swale, with lava flowing from a moundlike vent about two-thirds up the cone and rising some 10-15 meters above the upper terrace level. From this vent thin blue vapors arose. Some 15 meters above this was a small vent perhaps 4 meters across from which ejected material rushed as if from a blowtorch, yielding a small column of vapors and ash. The saddle-shaped crater rim, with a black resistant comb, formed a low scarp to the east. The lava flowed quietly down the terrace toward the east and spread over the lands of La Lagunita (pl. 24A).

This period beginning on June 9 and continuing for about 1 month was one of the most active and violent in the life of the volcano, surpassed only by the tremendous eruptions in late July. The striking changes that took place in the configuration of the broken cone, the kaleidoscopic variations in the eruptive activity, the rapid shifting of the lava vents, and the tremendous surges of viscous lava set this period apart from any other period in the history of the volcano. The alignment of the shifting lava vents in a northeasterly direction suggests a lava source from a fissure striking in this direction. The nature of the apparently solid but incandescent "combs" and "plugs" 


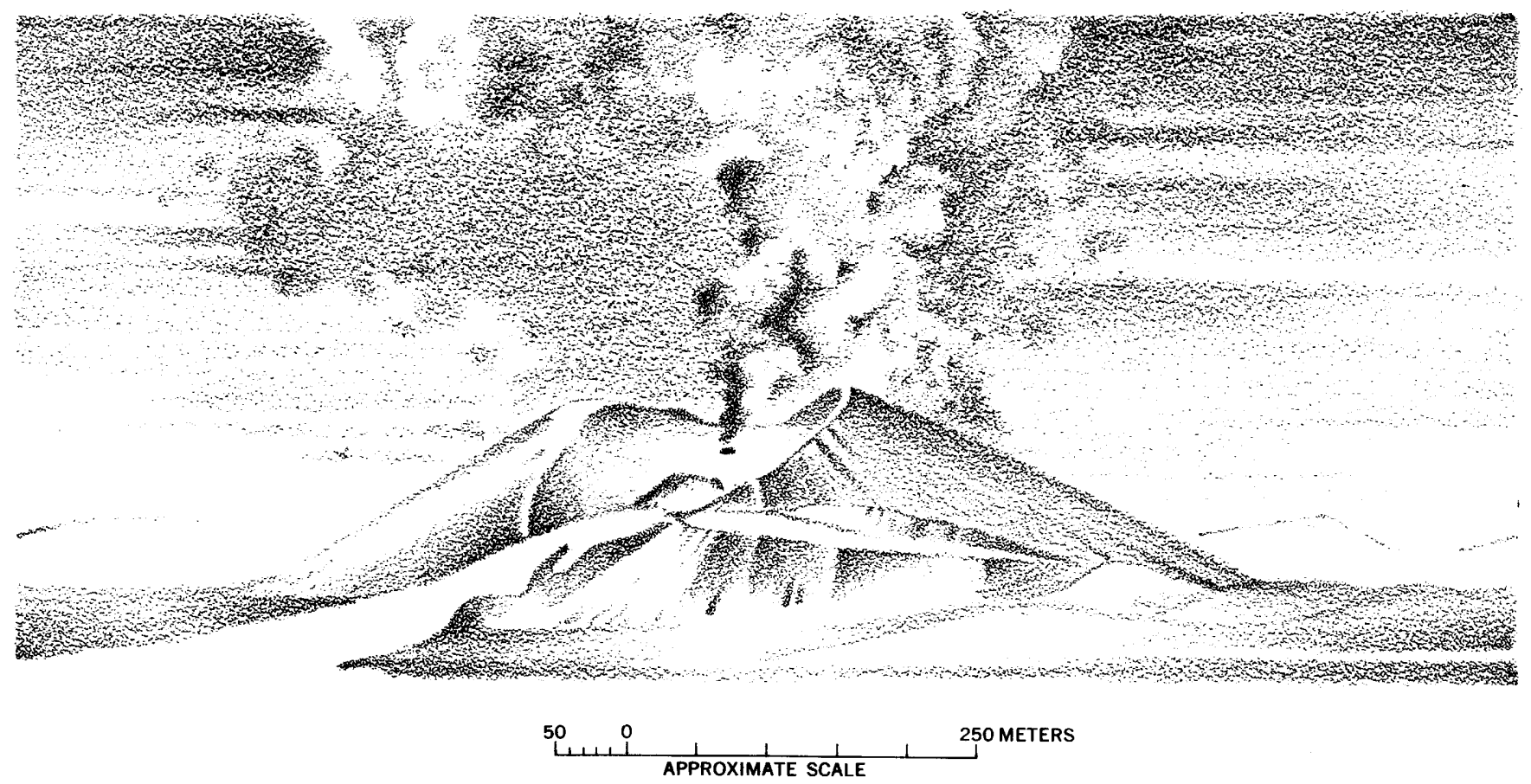

FIGLRE 117.-Disappearance of the resistant plug on June 19, 1943, by disintegration by a vent at its base. Below this vent is the resistant dome, from the base of which issues the lava flow. 
unfortunately could not be determined. The significant changes in the configuration of the cone are shown in figures 112 to 117.

\section{QUTTZOCHO RIDGE}

One of the conspicuous features of the volcano, until covered by the lavas of 1947, was the high ridge that extended from the northwest base of the cone to Cerro de Jaratiro. This ridge had its inception during the night of June 10, at the time of the break in the north side of the cone. Just how the ridge began cannot exactly be told, for during the day our attention was attracted by the phenomena of the advancing terraces and the outbreak of lava. At 7:40 p. m. our attention was drawn to the northwest base of the cone by a rising column of vapors. Upon hastening to the area, we found a newly formed ridge of furrowed ash. At one point a large tongue of torn and twisted lava projected through the disturbed ash cover. Dr. Frederick H. Pough, who was at the spot somewhat earlier, has described the area for us as follows:

Toward evening I noted an ascending column of steam about 275 meters west of the slowing flow of this morning. As it got darker a glow began to show at its base, like coals shining on steam. Upon closer approach it seemed to be coming from the top of the other side of a pressure ridge composed of loose, sliding pumiceous fragments. Thinking that a new lava flow must be coming from the other side of the ridge, I went around the nose and found a second ridge identical in appearance and character. It was then apparent that hot lava must be exposed near the top of the ridges.

The ridges were about 9 meters high and a little difficult to climb because of the loosely furrowed ash of which they were composed. They were also a little warm to the touch. As I surmounted the top I saw below a bed of small hot rocks about 30 meters across spread out before me. The margins were of larger rocks, covered with the loose material on which I was standing. As I knelt to set up the tripod of my camera $I$ felt a number of shocks as if the ridge were moving. I did not stay long, only long enough to take a few pictures. The top of the ridge was about $1 \frac{1}{2}$ meters above the level of the hot rocks. The surface was dark, the inner cracks were red, in fact it had the appearance, on a giant scale, of a furnace bed, pretty well burned down.

Shortly after descending the slope, the western ridge crumpled away as the lava bed rose a little higher and began to advance rapidly, ferrying along on its surface the more solid stones. The front advanced to the northwest, covering about a quarter of a mile in about half an hour. The whole front was actively crumbling away, and the flow advanced in a fairly thin sheet not much over 2 or $2 \frac{1}{2}$ meters high at the front. A tremendous whirlwind rose above the flow at the site of the former ridge; at the time it was thought to be escaping gas, but it later was decided to be a little tornado caused by the heat.

At about this time I was joined by Foshag and Cooper and we ventured up on the eastern pressure ridge to a point above the source of the lava. Little movement was apparent in the bed even now, though the slope underfoot was shaken by movements. The ash beds bordering the glowing lava were clearly being raised. They kept crumbling at the margins, and little trickles of incandescent dust ran down onto the furnace bed. The heat was intense and the site on which 
we were standing was moving; since we thought it might collapse into the lava, we did not remain there long.

This original ridge formed a line of low hummocks extending from the base of the volcano to the edge of the Mesa del Corral flow at the foot of Cerro de Jarátiro (pl. 29A). By June 12 this ridge was about 10 meters above the old ash-covered surface of the Mesa del Corral flow, and the ash showed much evidence of oxidation by intruded lava. On this day, too, a new flow of lava, the Parícutin flow, issued from the south end of the ridge near the base of the cone and flowed toward the north over the old ash-covered lavas.

The ridge grew almost imperceptibly, or at least we paid little attention to it, for at first it was little different from the usual hummocky aspect of the heavily ash-covered Quitzocho and Mesa del Corral flows, and the numerous outbreaks of lava from the cone attracted our attention. The smooth ash cover was elevated and domed, broken by numerous cracks, with patches of pushed or slumped ash (figs. 118, 119). The top of the ridge showed deep fissures in the ash and displaced or raised blocks of ash. A few patches of reddish oxidized lava were exposed in the flanks of the ridge. The ash was obviously being slowly raised into a domed ridge by the injection of lava beneath, perhaps by additions of fluid lava to the underlying old lava flow from a source at the northwest edge of the lower terrace.

\section{ACTIVITY OF JULY}

On July 17 Donald White found an apparently fresh slide of the cone on the southwest slope, directly opposite the old break on the northeast side $^{14}$ He reports seeing clouds of dust rising from this area earlier on the same day. The glow of incandescent material was visible in the break, but no lava was observed. Steam and vapors arose from the landslide area suggesting the possibility of lava flowing beneath the rubble. This slide took place at the locus of the earlier Mesa del Corral vent. Later flows were to break out in this same sector.

The Lagunita lava (pl. 25A) on the northeast side flowed intermittently until July 19, when its movement down the slope was very slow, about 1 meter in 5 minutes. In the evening of the 19 th the last weak surge of lava from its vent was observed. The break in the nor theast slope of the cone was now reduced to a wedge-shaped segment that formed a sag in the upper line of the crater. At the inverted apex of the triangular break about half way up the slope of the cone was the lava vent. The lava flowed down two trenchlike channels, spreading over the fields of La Lagunita and Turímbiro. This flow was similar to other flows, a blocky lava, its surface covered by a mantle of blocks and clinkers. The last lava of this flow moved as a tongue over the

14 Unpublished notes. 


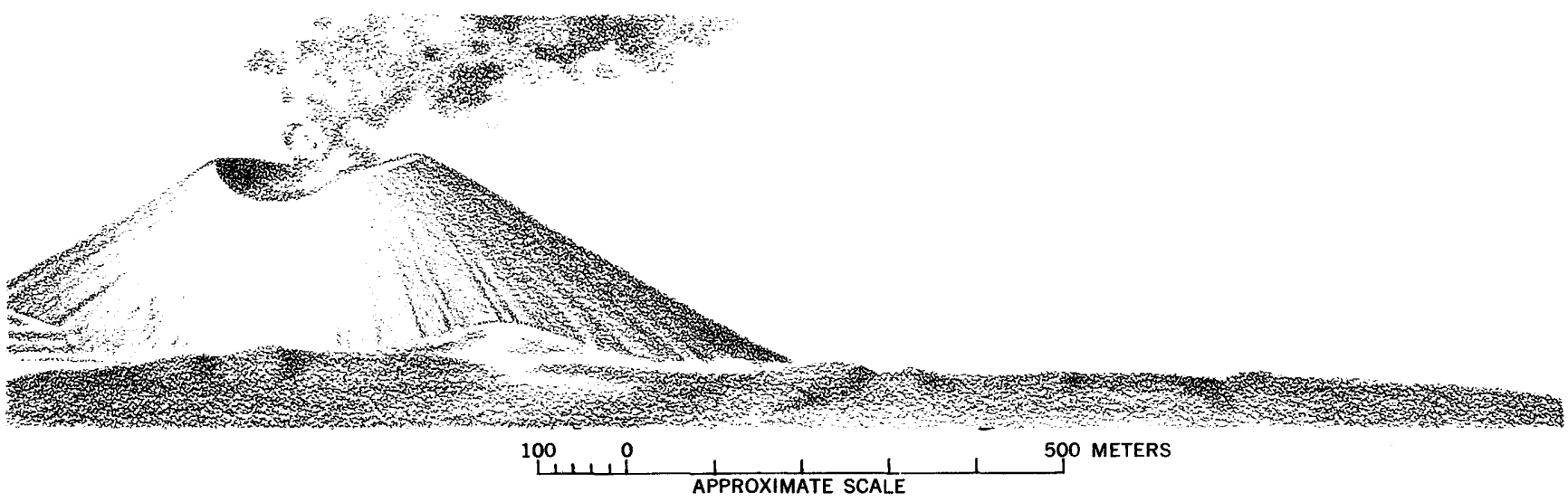

Figure 118.-Quitzocho ridge in early June, showing the smooth ash-covered Quitzocho and Mesa del Corral lava flows.

X

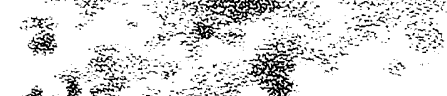

.
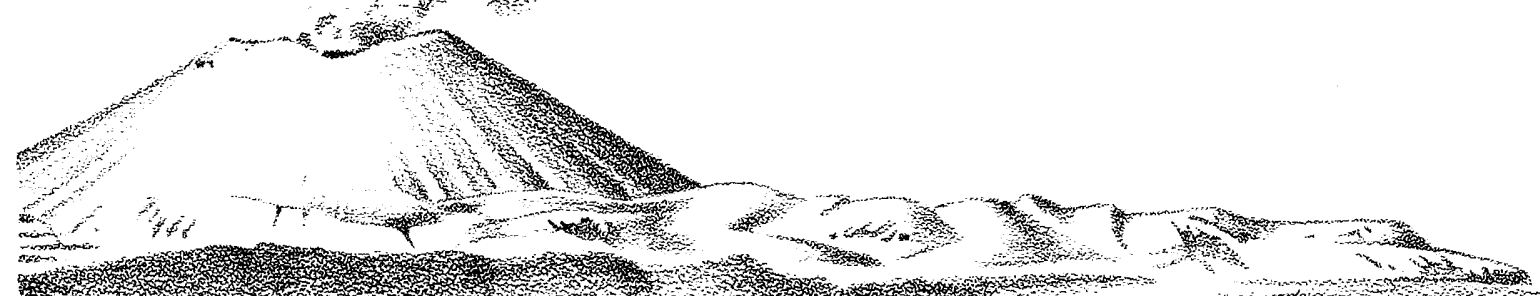

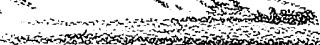

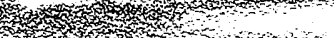

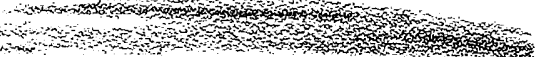

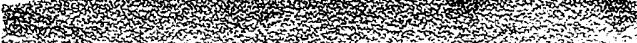
500 METERS

100,0 $\frac{1}{\text { APPROXIMATE SCALE }}$ $1 \quad 500$

Figure 119.-Quitzocho ridge after the flow of June 9, 1943, showing the smooth ash raised by injection of lava below. 
ash-covered Quitzocho lava between the eastern end of Cerro de Jarátiro and the base of the cone.

With the diminution of the lava flow from the vents, the break in the cone began to fill with ejectamenta from the crater. With each new surge of lava, now at intervals of 2 days or more and then of short duration, ash slides occurred in the break; but with the total cessation of lava flows, the cone very soon returned to its normal even slope.

The last phase of this interesting period of lava flows was the brief outburst of chimneylike vents on the slopes of the cone (pl. 26A), these vents coinciding as nearly as can be determined with the lava vents of this period. ${ }^{15}$

On July 27 we returned to Parícutin after a day's visit to Uruapan and found striking changes taking place. In traveling from Uruapan to San Juan Parangaricutiro, we were struck with the large quantity of pinkish or reddish dust that arose from somewhere near the north base of the cone. This dust obscured the cone, so that we could not clearly perceive its state, although it was apparent that some significant change was taking place.

From San Juan Parangaricutiro we passed through the now entirely depopulated village of Paricutin, where many of the houses had collapsed from the weight of ash. The Paricutin lava flow that threatened to engulf the village had now practically ceased its advance, although an occasional creaking noise indicated that there remained some slight movement in the mass. Scattered weak fumaroles had formed, spotting the lava with thin patches of white and yellow salts.

Seen from the Paricutin Arroyo, now completely filled with lava, it was strikingly evident that the Quitzocho ridge had greatly increased in size and that the north slope of the cone had suffered another slump such as we had observed in June. According to our informants, this new break in the cone and the changes in the topography of the Quitzocho took place at 2 p. m., during our absence, without preliminary warning (pl. 24B).

The cone showed a wide concave break on its north front, now partly restored by the fall of bombs and ash. The north side was a rather flat facet of the cone, at the foot of which was a rubble terrace, or rather a ridge, for a shallow valley separated the terrace from the cone. This terrace, oriented towards the north, joined the Quitzocho ridge to the cone. Between the terrace and Quitzocho ridge was a saddle, which we frequently traversed later in going to and from the opposite side of the cone. The south end of the Quitzocho ridge rose about 130 meters above the original surface and was crowned by several large irregular masses of rock. These rock masses, we were

${ }_{15}$ Unpublished notes of Ezequiel Ordóñez. 
later to discover, were congealed lava and the remnants of the lava vent from which the June lavas issued. They had moved several hundred meters toward the north, carried out upon the surface of a lava flowing below. For many months the incandescent fissures in these rocks served us as guides at night, and the rocks we called Los Faroles.

The Quitzocho ridge had changed from a relatively low ridge ( $\mathrm{pl}$. $29 \mathrm{~A}$ ), with smooth slopes of velvety-appearing ash to a mesa capped by bedded ash (pl. 30A) and with steep slopes of pinkish and reddish oxidized ash and rubble. As the sides slowly expanded, blocks of lava and streams of clinkers rolled down the slope, raising a pinkish or reddish dust that settled over the wet, black ash that covered the old Quitzocho and Mesa del Corral lava flows.

But the most striking change was shown by the ridge front, facing the slopes of Cerro de Jaratiro. This front, now about 100 meters high, was a steep, rugged and broken scarp, turreted with huge masses of lava. This scarp was ever changing its features. The huge exposures of congealed lava were in a constant state of disintegration to small rubble or fine sand which streamed down the seamed face of the ridge like small flows (fig. $120 ;$ pl. $29 B$ ). A viscous lava frequently bulged from beneath the huge blocks; and the whole front, although apparently congealed, was slowly advancing. At times huge blocks of rock many meters across slowly tilted forward, then rolled to the foot of the face with an earth-shaking thud. Although many masses were lost from the front by disintegration or fall, new ones formed by crevassing of the front. One of the results of this action was an accumulation of debris at the foot of the slope made up of angular fragments ranging from 5 meters in diameter to fine sand and dust. During this disintegration pink dust rose in copious quantities. At night we observed what appeared to be short tongues of flame playing over some of the crevices in the congealed masses.

Within the next few days several flows broke out laterally, like pigs from a sow, from the Quitzocho ridge. Very near the north scarp of the ridge nearly a kilometer from the cone, the first, a short flow, issued from an orifice on the west slope and encircled the nose of the ridge. A second broke out from a point near the first and flowed a short distance toward the northwest, yielding a scarp of jumbled blocks and clinkers (pl. 42B). A third flow breached the ridge about 100 meters back from its nose and poured out in a brilliant flood of incandescent lava, carrying with it huge blocks riding majestically down the incandescent stream. This sheet flowed quietly but rapidly at its orifice, but the front soon slowed to a speed of about 40 meters per hour. This flow, moving on top of the Paricutin flow, reached about one-half the distance of the Parícutin flow and there halted, 


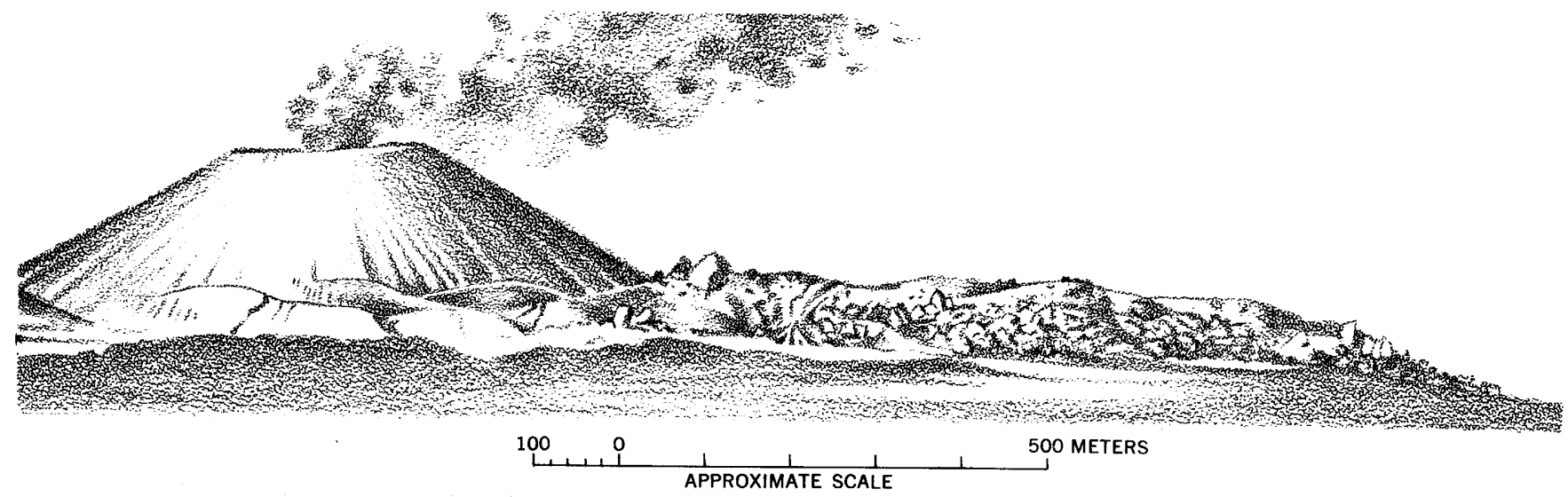

FigURE 120.-Quitzocho ridge after the injection of lava in July-August 1943. Disintegrated lava appears from below the ash. The protuberant blocks are cores of disintegrating lava. 
forming a terrace upon the older flow. This second flow toward Parícutin village we have called the Tititzu flow, because its front coincides generally with the lands of Tititzu.

Since the break of the cone on the morning of July 24, the crater was in intense activity (pls. $25 B, 28 A$ ), yielding a dense and heavy eruptive column with heavy cauliflower heads. The amount of material ejected was great enough to heal the break in the cone and restore it to almost complete symmetry. Heavy ash clouds drifted to the southwest raining ash upon the pine forests of Cerros de Tancítaro. On July 31 , at 11 a. $\mathrm{m}$., a distinct change in the activity in the crater took place, similar to the change that preceded the break of June 10 . The noise increased, and the eruptive column diminished until the activity was reduced to a thin spasmodic column of tenuous vapors (pl. $26 B$ ), or even to no visible vapors at all. Larger ejectamenta increased, and large viscous masses were hurled high in the air. One could frequently discern their shapes and how they changed in their flight through the air. The explosions, coming each 4 to 15 seconds apart, gave off a deep throaty reverberating roar, and the trepidations were distinctly perceptible at camp. Shortly after $6 \mathrm{p}$. m. the first remarkable "flashing arc" occurred. An arc of yellow light shot from the crater with great speed, flashed into the sky, and disappeared. This was immediately followed by a tremendous burst of immense masses of viscous incandescent lava which, upon falling on the flanks of the cone, flowed slowly down the slope. Six seconds later, the time for sound to travel from the crater to the camp, a tremendous blast of noise shook the camp. This awesome and startling spectacle brought involuntary bursts of applause from the tourists gathered near the camp, as if the spectacle were a part of a great theatrical production.

Other similar bursts took place during the night at intervals of 15 minutes to an hour. With darkness the explosions were even more awesome than in the dusk of twilight. Tongues of lava repeatedly rose high above the crater rim, there to burst into shreds (pl. 27 $A$ ). We estimate some to have risen 100 meters above the rim. They appeared like huge bubbles, botryoidal on the surface and presumably filled with gases. When they burst, huge glowing masses of viscous lava were flung over the cone, some so far as to clear the slopes and fall on the surrounding ash field. Sometimes a second tongue, overtaking an earlier one, would tear it into huge shreds.

The heaviest explosions, however, took place within the crater, and it was with these that the flashing arcs occurred. The first signal of an approaching arc was a bright and widespread suffusion of deep pink above the crater, a reflection of the incandescent lava in the crater upon the rising vapors and the low hanging clouds above. This was 
followed immediately by the rapidly expanding arc of yellow light, seemingly rising with lightning speed into the sky. Quickly thereafter came the burst of huge incandescent orange lava masses (pl. 27B) and a blast of warm air distinctly perceptible 11/2 kilometers away. Lastly came the deafening roar of the explosion.

In the morning when we visited the base of the cone, we found huge bombs scattered about. Many were spindle bombs, some 11/2 meters in diameter and somewhat more in length. Large masses of congealed lava were plastered upon the other bombs at the base. All the bombs were forms characteristic of molten but rather viscous lava. One huge fish-shaped bomb measuring 7 meters long fell several hundred meters from the foot of the cone. This was the only time that we observed characteristic spindle bombs among the ejecta of the volcano.

The character of the activity and the nature of the bombs led us to believe that a lake of lava had arisen in the crater and that huge bubbles of gas rising through the conduit had brought on the terrifying explosions of the night before.

\section{ACTIVITY IN AUGUST}

During the morning of August 2, heavy explosive activity continued with the ejection of large bombs but modest eruptive columns. In late morning, explosive activity increased and at 12:30 p. m. had reached such a violence that we looked for some new event to occur. At $1 \mathrm{p} . \mathrm{m}$. the north slope collapsed with startling noiseless suddenness. A great section, about one-quarter of the periphery of the cone, slid out amidst a tremendous confusion of ash (pl. $28 B$ ). Soon great jets of dense black ash shot up from the edges of the break: first on the east about two-thirds of the way up the break, then several lower down, and then from the west side of the break-each persisted for several minutes and then died down, only for new ones to break out some other place. A huge ash jet, ascending to a great height, arose from the middle of the break. The sudden apparition of these startling ash jets and the kaleidoscopic confusion of dust and fog made it impossible to obtain a clear sequence of the events that were taking place in the break. After an indeterminate period during which we watched this startling play of forces, the action subsided; and we could discern a sheet of lava moving down the slope from a vent not distinguishable to us, flowing down a valley formed by the terrace of the collapsed cone segment and the broken slope of the cone.

The Quitzocho ridge now took on new movement. By sighting from a point at the camp to a landmark on the slopes of Cerros de Tancitaro opposite, one could follow the perceptible movement of the rocks (Los Faroles) that crowned the ridge. It was estimated from rough angular measurements that the ridge moved northward almost 150 meters 
during 24 hours. After this first day's advance, the movement ceased but resumed several days later for an additional advance of about 75 to 100 meters.

Following the break of the cone, the crater again assumed its more normal state, with heavy billowing eruptive column; and the summit of the break underwent a period of attrition, in which a north and south crater vent again became evident, as in June. And, as in June, the south crater vent showed a more sustained and regular action than the north vent. The north vent was spasmodic in its activity, frequently quiet, sometimes yielding bursts of tremendous violence and magnitude. A feature separating the north from the south crater was a dikelike comb, extending across the saddle between the two vents. This showed many incandescent fissures at night and frequently showed areas of disintegrating blocks, but it never entirely disappeared until covered by the ejectamenta that finally healed the break.

The lava flow from the break moved toward the northwest and spread out in a broad sheet at the foot of Cerro de Canicjuata, eventually meeting the old lavas of the first Parícutin flow.

Following the events of late July and early August, the volcano settled into a state of irregular activity, the eruptive column varying from a lazy emission of pure-white vapors to dense, heavily ashcharged columns, from periods of almost silent eruptions to heavy roars, and from a few ejected bombs to splendid night pyrotechnics. During this erratic and variable period, the summit of the cone showed frequent changes in its configuration, losing its even and level outline. This was due to the shifting explosive vents in the crater and to collapse and slides within the crater itself. During the previous 6 or 7 months any irregularity in the configuration of the cone was transitory, and the contour of the cone was rapidly restored to its normal form by the heavy falls of bombs and ash. In fact, it was surprising with what rapidity a serious break in the cone could be restored.

During this period of erratic but moderate activity, no lava flowed from any vent.

On August 25 the crater, as it had in early June and late July, showed a diminution in activity followed by intense explosive activity. At first the eruptive column was greatly reduced and even ceased at times, but heavy explosions in the crater increased in intensity during the night and the following day, reaching an intensity equaling the explosions of early August (Ordónez, 1943), causing some alarm to the observers in the camp at Cerro de Jarátiro. During this tremendous activity some instantaneous earth shocks of medium intensity were felt, and intense rumbles were heard from the depths of the 
earth. Six or seven times during these days sudden explosions of unusual intensity occurred. From the camp one could see vapors of a tenuous yellow arise with each explosion from the center of the crater. At the same time, bluish fumes arose from a vent to the east. With each strong explosion a huge halo (flashing arc) shot up with extraordinary rapidity, momentarily lighting up the top of the cone and even the blue sky and the clouds. A small break in the crater showed on the northeast side, exposing a small irregular crest like that seen in late July and early August. In this period of heavy explosions, lava broke out from the southwest base of the cone, yielding a small flow that moved along the south base of the cone. Another broke out of Quitzocho ridge about 600 meters from the base of the cone, and the Quitzocho ridge (fig. 121) itself showed evidences of new movement or growth. The ridge not only increased in elevation; but huge blocks, even larger in size than those of early August, semifluid in character, rolled down the high front facing Cerro de Jarátiro, raising clouds of pinkish dust.

\section{ACTIVITY OF SEPTEMBER-OCTOBER}

From late August to September 18, the crater showed variable activity (pl. $30 B$ ), frequently much reduced in explosive activity, erratic and weak. The bursts came at irregular intervals of from 3 to 20 seconds, often sending up no more than a single sharp finger of ash and bombs into the air.

Since the beginning of the volcano, whirlwinds charged with volcanic dust were common on the ash-covered lava flows where the cool air from the surrounding hills, meeting the hot air arising from the lava, caused atmospheric turbulence. Sharply defined whirlwinds, often rising to great heights, added a majestic new element to the landscape. Sometimes as many as a dozen could be seen; some almost fixed in position, others moving leisurely over the lava, all rotating with considerable speed. Where they encountered trees, they had the force to tear off large limbs and hurl them into the air.

On September 18 we saw many well-formed whirlwinds of striking distinctness, which formed on the slopes of the cone. A black, heavily ash-ladened eruptive column rose lazily from the crater and drifted at a low altitude toward the west. Dust from the falling bombs was slowly drawn along the slope of the cone toward the summit where it met the ash cloud from the eruptive column drifting downward. Here they began to whirl, growing upward until they met the low overhanging dark pall of the eruptive column. Some were thick and swirled languidly; others were thin, sharply defined, and rotating rapidly. Some were estimated to be a kilometer long, extending from the slope of the cone to the pall of the eruptive 


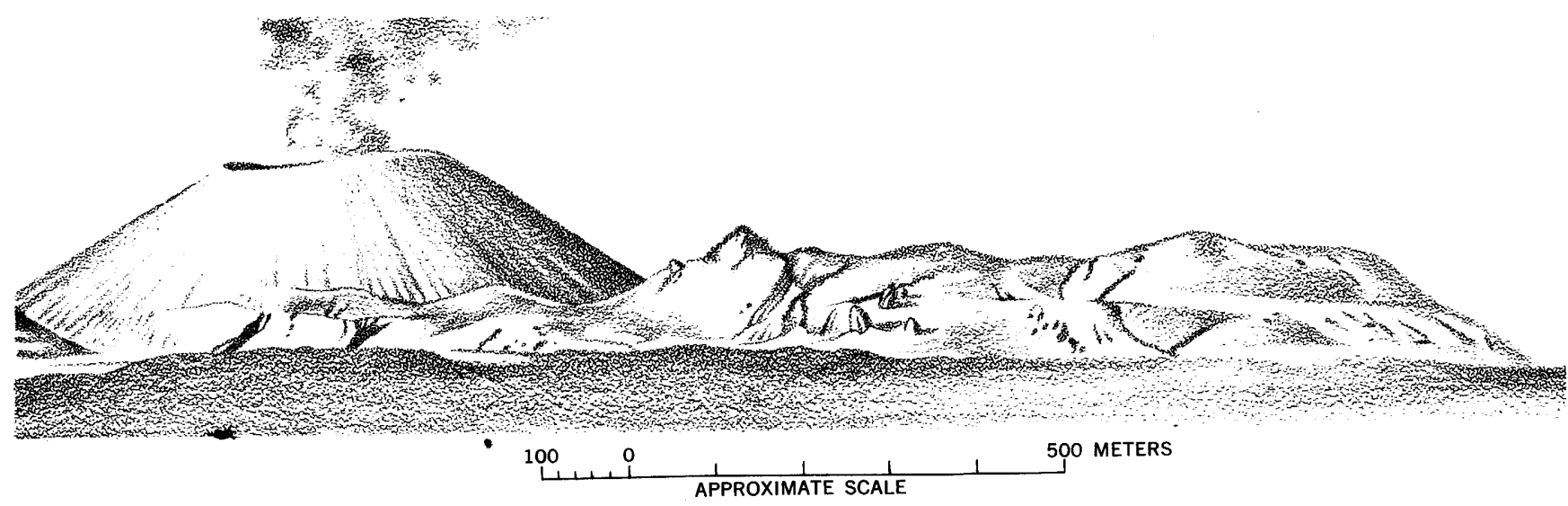

Figure 121.-Quitzocho ridge in late 1944. This is the final development of the ridge, with its asperities smoothed by ash. 
column. Some changed their positions very slowly; others moved down the slope of the cone and across the ash fields toward Cerro de Canicjuata before breaking up.

On September 18 the eruptive column began again to subside, and heavy throaty explosions again took place indicating another probable outburst of lava which, indeed, occurred on the afternoon of this day from the southwest base of the cone. The lava advanced along the south and southeast bases of the cone, moving over the lava of August 25-26. According to Ordóñez (1943) the very fluid lava formed a low continuous fountain on the flank of the cone some 60 meters above the older lavas and flowed down the slopes between two levees. It spread out at the base of the cone as a low dome, which expanded to a flow, advancing over a width of 100 to 300 meters for a distance of 400 meters in 3 days and spreading over the basin formed by the cone and the slopes of Cerros de Tancítaro to the south.

Lava flows from the same vent were again observed on October 2-4 by Donald White, who describes them as follows: ${ }^{16}$

October 2, 11 a. m.-From the top of a small hill, I could see a fountain of lava rising as a pulsating but continuous column, issuing from a vent low dow: on the side of the cone and apparently on the eastern edge of the landslide seen in July. The fountain rises as a nearly solid column to a height of 8 to 15 meters, then falls into a lava pool and flows swiftly to the base of the cone. The vent is a point of loud noises. The fountain yields bluish-white smoke changing upward tc yellowbrown fumes. The lava flow also gives off fumes of the same blue white, but less dense. This color is similar to one type of fumarole.

At 11:30 a. $\mathrm{m}$. the vent is apparently moving slowly downhill by eroding the loose material of the cone. It has formed a low spatter cone about the vent except on the downhill side, which is a "river" of lava, flowing at least 1 or 2 meters per second, but increasing to 5 meters per second when a steep lip temporarily formed in the "river." The fountain died down by the time we approached it, and the lava then welled out silently, except for an occasional burst that threw molten globs as high as 45 meters into the air, with accompanying puffs of gases.

By 11:45 a. $\mathrm{m}$. the gas vent has formed a trench above the outlet, this trench marking the path of downward migration of the lava vent. The trench is partly filled with spatter fragments. Steamlike white vapors that are denser than the vapors from the lava stream come from the gas vent. The vapors are emitted in puffs that do not correlate with the bursts of lava in the lava vent.

At $12 \mathrm{p} . \mathrm{m}$. the eruptive column in the crater is much stronger, and bombs start falling outside the crater. Explosions in the lava vent die out, but the lava stream continues flowing. This lava vent is $\mathrm{S} .35^{\circ} \mathrm{W}$. of the center of the cone. There is no breakdown of the cone in connection with this flow, in contrast to former flows.

October 3,10 a. $m$.- The front of the new flow is more active than yesterday morning, estimated at one place at 10 meters for 24 hours. Near the top of the main crater are peculiar radial "cracks" in the cone from which vapors escape.

At 10:30 a. in. the lava vent is still very active, the lava welling up and flowing

${ }^{16}$ From unpublished notes of Donald White, U. S. Geological Survey. 
silently down its course; but there are "bubble bursts" with puffs of gases, and molten lava is thrown 6-15 meters in the air. A prominent spatter cone, 10 or 12 meters high, has been built up around the vent, except on the downhill side where the flowing lava keeps it open. The speed of flow is less than yesterday, and the level of the stream is lower and does not fill the trench formed by the dikes at its sides. The lava vent has kept the same position during the night, without further migration downhill. The gas vent is still active.

At $2 \mathrm{p} . \mathrm{m}$. the crater shows what are apparently two eruptive columns: one, to the northeast, is nearly pure white like water vapor; one, to the southwest, is light to dark gray. The two columns rise constantly by pulses several seconds apart. This continued until 7 p. m.

October 4,5 p. m.-The gas vent is still active, but the lava vent has almost ceased its activity. There are no explosions or spatter, and the lava stream, now blacker, moves much more slowly, estimated at 1 meter in 5 or 10 seconds.

October 5,5 p. m.-No gas or vapors are coming from either the gas or lava vents, and the lava has ceased flowing from the vent. The lava level in the trench has lowered, leaving walls 6-9 meters above the lava.

On December 2 we were able to enter the trench of this flow to the locus of the vent. The actual vent itself was filled with ash, in part. newly fallen and in part material that had slid into the orifice. At the vent site the ash was damp with a liquid of syrupy consistency and a strong astringent taste, and a strong odor of hydrochloric acid pervaded the spot. This wet ash was hot and steamy, indicating that gases and vapors continued to be emitted from the ash-filled vent. Downslope below the vent was a trench 5 meters wide with walls 3 meters high, the original channel of the flow. The walls showed the successive layers of repeated surges of lava. The upper layer, or flow, about half a meter thick, was without gas vesicles and showed a rugose surface both on top and bottom. A thin bed of oxidized red ash separated it from the lower flow. In the west wall of the trench, steam issued from between the individual flows, coloring the wall yellow with iron and other salts. In the east wall glowing lava could still be seen in the cracks, about which a white sublimate with a saline taste was deposited.

After this period of lava activity, the cone again passed into a relatively quiet stage, with the eruptive column reduced in size but without the heavy explosions that presaged the advent of new lava flows (pl. 31A). The eruptive column frequently carried little ash and rose in lazy cottony volutes and apparently consisted largely of steam. Activity continued in this erratic manner until October 15, when a new phase of activity was about to set in.

SUMMARY OF QUITZOCHO PERIOD

The Quitzocho period may be defined as that period connected essentially with the activity of the original primitive or Cuiyúsuru 
vents. This period continued from February 21 to October 19, when the principal activity shifted to another locus, the Sapichu ${ }^{17}$ vent. The first phase of this period, from February 21 to March 18, was devoted largely to the building of the new cone by the heavy expulsion of bombs. Explosive activity was continuous, rather variable but usually violent. Little ash fell, but great quantities of bombs were ejected, and during a brief period of 25 days the cone grew from a small mound of only a few meters elevation to an edifice about 200 meters high.

The first flowing lava of the new volcano probably reached the surface early on February 21, or even during the night of the 20th, perhaps 8 hours after the initial outbreak. This lava flow, here called the Quitzocho flow, issued in erratic surges from one of the vents in the crater. When lava flowed, the new and weak cone was easily breached by carrying away the wall to yield a horseshoe-shaped cone. When the surge halted, the breach was rapidly repaired. The configuration of the cone varied almost daily with the changes in the eruptive activity of the volcano.

A sudden change to a heavy cineritic phase began on March 18 when the explosive activity that yielded abundant bombs changed to a heavy emission of ash, which spread over a wide area and destroyed cultivated fields and forests. A continuous eruptive column rose to a great height, as high as 8,000 meters above the cone. Two brief outbreaks of lava from a vent on the south flank of the cone yielded two relatively small flows, the Pastoriu and the Mesa del Corral flows. Both outbreaks of lava were preceded by a partial breaching of the cone.

This heavy cineritic phase ended on June 9 when a period of variable activity began with erratic eruptive activity in the crater and recurring lava flows from ephemeral vents on the northeast flank of the cone. When the cone was partly breached preceding these flows, a large sector of the cone was partially carried away to form a high terrace and a greatly weakened north side of the cone. Lava flows from these ephemeral vents covered portions of the earlier flows as well as new ground to the north, northeast, and northwest of the cone.

Three lava vents were intermittently active during this period. There were two short flows from a vent on the south flank of the cone and one small flow from the west flank of the cone. But the greatest

\footnotetext{
17 The authors prefer the spelling Zapichu, following Gilberti, Diccionaria de la lengua Tarasca; Basalenque, Arte de idioma Tarasca; and other authorities; but for the sake of consistency have agreed to follow the spelling used in previous chapters of this bulletin.
} 
lava activity came from vents on the north flank of the cone. The flows of this period are tabulated below:

Chronology of lava activity, February 21-October 18, 1943, flow

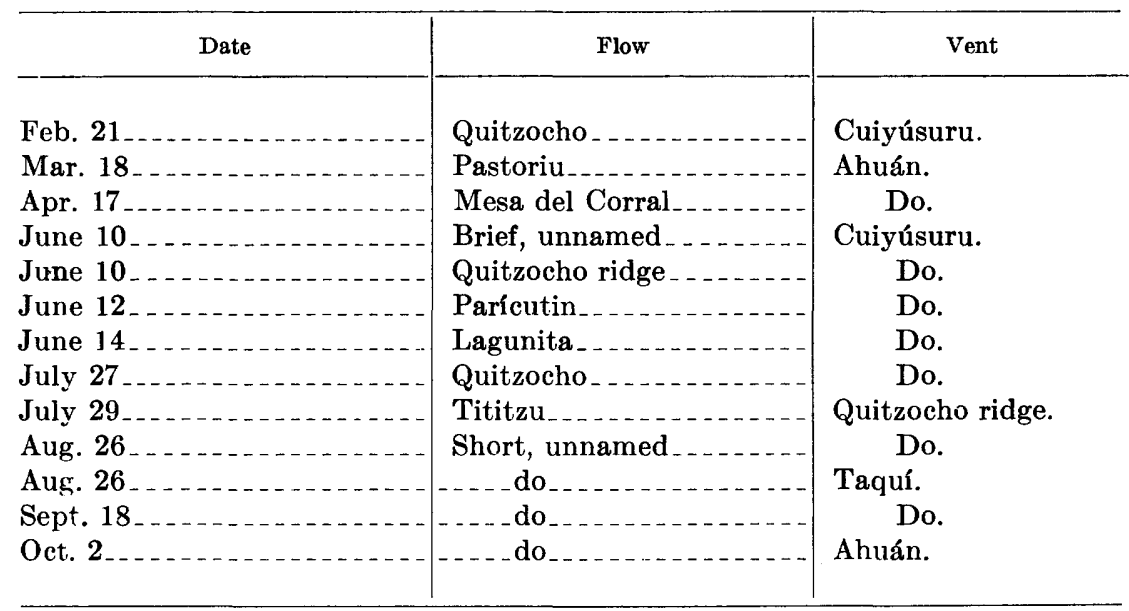

The outbursts of lava, in all cases, were immediately preceded by rapid and startling changes in the activity in the crater. The high, heavily ash-laden eruptive column shrank rapidly in size, decreasing to the emission of tenuous vapors and the ejection of large viscous bombs, irregular in shape, accompanied by heavy explosive noises. This type of activity was followed, within 12 hours, by an outbreak of lava from the base of the cone, or its lower flanks, immediately followed by a return to normal of the eruptive activity.

Usually the appearance of flowing lava was immediately preceded by a collapse of a segment of the cone, brought about, as one could see in the development of the Quitzocho ridge, by the lava stream carrying the incumbent cone material away from the cone. Such events took place on April 17, Mesa del Corral flow; June 10, various flows of that period and the injection of Quitzocho ridge; July 17, no visible lava flow; July 27, injection into Quitzocho ridge; early August, injection into Quitzocho ridge and the Tititzu flows; and August 26, small collapse, no flows. The sequence for events during an outbreak of lava is as follows:

1. Normal heavy eruptive column.

2. Rapid change to heavy crater explosions, with diminished eruptive column.

3. Rafting of segment of cone.

4. Appearance of flowing lava.

5. Return to normal eruptive column. 
An event of unusual interest during this phase, was the growth and development of the Quitzocho ridge by the injection of lava or the passage of a lava flow below the ash cover. It received successive increments of material on June 10, July 27, and August 26. It yielded four relatively small lava flows from its flanks and grew to be one of the prominent topographic features of the volcano.

A cursory comparison of the volcanic activity during the early phase of this period with later phases might suggest that the fundamental nature of the eruption had changed-that the change from heavy bomb explosion to heavy ash ejection and the change from a horseshoe-shaped apparatus to a symmetrical cone was due to a change in the character of primary activity. A consideration of these changes has led us to the conclusion that the fundamental activity in general remained unchanged and that the apparent change in the nature of the volcano's activity was due to the increasing incumbent load of ejectamenta forming the cone. After the first month's activity the cone had grown so large that flows which previously would have broken out at the base could no longer completely breach the walls and now carried segments of the cone only a short way. The change from a heavy bomb stage with little ash to a heavy ash stage was the result, in part, of an increasing degree of choking of the vents in the crater. In the early stages, when bombs were the principal ejectementa, the rising gases were free to escape from the rising column of lava. With the accumulation of debris to form a more stable cone, the exit of the gases was impeded by ash and other debris that slid from the inner slopes of the crater or fell back into the vent, thereby giving rise to a heavily charged eruptive column. We frequently found bombs that sbowed considerable attrition, even to the extent that some became as round as cobbles, owing to their repeated ejection from and descent to the throat of the volcano. Where two or more vents acted differently, as in mid-June when the south vent yielded steam with little ash and the north vent ejected a column heavily charged with ash, it was quite apparent that the vent was fairly open in the first case and seriously choked with accumulated debris in the second.

Taking into consideration this modifying effect of the growth of the cone upon the eruptive activity, there appeared to be no essential change in the nature of the rise of the lava in its conduit from the first and through the succeeding periods.

We have made calculations of the amount of solid material emitted by the volcano during the period February 20 to October 20, 1943, both as lava and as ejected ash, lapilli, and bombs. The bases for these calculations are the areal extent of the lava flows and ash falls, as measured on the map prepared for us by Sr. Adán Pérez Peña; 
estimates of the thickness of the flows, as viewed in the field; and an estimate of the porosity percentages of the various products. For ash and fine lapilli, measured and weighed volumes indicate that fairly well settled ash has a weight of 1,500 kilograms per cubic meter and fine lapilli, 1,250 kilograms per cubic meter. Although well packed and settled by the continuous movement, the cone with its fine and coarse pumiceous ejectamenta has been assumed to have a porosity of 60 percent; while the flows, with their vesiculation, interflow rubble, and fissuring are calculated to have a porosity of 50 per cent. The figures so arrived at are contained in the following tabulation:

Weight of ash and lava, Paricutin

[February 20-October 20, 1943]

Quitzocho flow

Pastoriu and Mesa del Corral flows 3

Parícutin flow

Lagunita flow 10

Quitzocho ridge

September-October flows

Ash:

Cone 110

Mantle

Total $\ldots \ldots$

Average rate per minute_... _...

Average rate of ash per minute _.............. metric tons__ 1, 200

While these figures are only approximate, they do indicate the great preponderance of ash over lava during the first stages of the volcano, there being roughly 10 more times more ash than lava. The average rate of ejection of ash, 1,200 metric tons per minute, gives some measure of the tremendous explosive activity of the vent. With an average rate of explosion of about 15 per minute, the average weight of ejectamenta in each burst is about 80 tons.

It was during this period, the Quitzocho, with its heavy ash and bomb falls, that the new volcano built its cone. As was later seen, the increment of ash and other ejectamenta upon the cone from this period on was offset by rainwash, slumping and other degrading processes. The original vent in Pulido's cornfield on February 20 had an altitude of about 2,400 meters above sea level. At the end of the Quitzocho activity, the highest point on the crater rim reached an altitude of about 2,725 meters above sea level.

The early growth of the cone appeared extraordinarily rapid; from 6 or 8 meters on the morning of February 20 to 30 meters or more at 
midafternoon of the same day and 167 meters 6 days later. Naturally, as the cone grew larger, the same quantity of ejected material spread over an increasingly larger area of cone, effected a decreasing increment in elevation. Nine months after the initial outbreak the cone had reached maturity.

On a number of occasions we timed, by stopwatch, the rate of fall of the visible bombs from the highest point of their flight to an elevation of the crater rim. The maximum time interval so measured was 16 seconds. From this rate of fall, the maximum elevation of distinguishable bombs is 4,000 feet $(1,250$ meters), and the speed with which these bombs left the explosive vent, 550 feet per second.

\section{SAPICHU PERIOD}

\section{SAPICHU VENTS}

The 7-month Quitzocho period, from March 18 to October 17, was followed by a $2 \frac{1}{2}$-month period in which the principal activity shifted to a subsidiary vent that broke out near the northeast base of the cone and much reduced the eruptive activity of the main crater. A small cone, built up about this subsidiary vent, was named Sapichu by the Tarascan inhabitants of the area, from the Tarascan word "sapichu" (little or small). This period of activity we shall call the Sapichu period. The continuous eruptions of Sapichu yielded one of the most spectacular sights to be seen during the history of Parícutin.

On the 17 th of October, earth tremors, which were frequent although weak during the preceding phase, greatly increased both in number and intensity until they became almost continuous; and the dishes in the refreshment stands on Cerro de Jarátiro rattled almost continuously. These trepidations continued until the night of October 18 . According to our informant, Sra. Aurora Cuara Soto, at 11 p. m. a series of vents suddenly opened, aligned in a northeasterly direction. This new outbreak began with a heavy explosion; bombs and lava fragments were hurled into the air from the new vents to a height somewhat greater than the main cone. According to Manuel de la Vega, Mexican alpinist, the explosion was immediately preceded by a strong earth shock and followed by subterranean noises. At the same time, a fissure several hundred meters in length formed in the Quitzocho and the incumbent Lagunita flows, and five or more vents opened up, spouting incandescent lava many meters into the air (pl. 31B). Sra. Aurora Cuara estimates that the line of vents extended for 300 meters. From these vents, "flames" of bluish yellow and orange arose. The accompanying noise was like that of a starting railway locomotive, a noise we had come to associate with escaping gases from a rising lava column, usually at the initiation of a new flow or lava surge. Meanwhile the crater of the cone ceased ejecting bombs, and the eruptive 
column changed to a dense black ash column, with, she said, "flames [incandescent ash] that covered all the horizon."

According to Sr. Arno Brehme, the vents followed the crest of a low domed ridge fissured parallel to its axis, suggesting that the lava of the Lagunita flow had first been elevated by injection. De la Vega reported 5 vents. Brehme also reported 5 ; but Sra. Cuara, who from the vantage point of Cerro de Jarátiro had an excellent view, saw 7 . Three of these, in the lava field northeast of the base of the cone, yielded steam, a few small bombs, and no ash. An orifice on the flank of the cone was more active, ejecting viscous lava in small quantity to form a small mound. But the principal vent, which was to persist and build a cone, was in the lava field near the base of the cone and ejected numerous viscous lava bombs, and a wide lava flow issued from the vent. Ordónez (1943) reports that three vents remained in activity on the second day. One was active only at long intervals. A second, more active, with a low cone half open toward the north, was situated on the flank of the cone. The third vent, lying directly northeast of the second vent, was the largest and was partially inclosed in a horseshoe-shaped "cone." This third vent showed explosive bursts at intervals about a second apart and threw up a column of viscous lava bombs to a height of 120 meters, accompanied by moderate to formidable explosive noises.

On October 21 the main new vent was in full eruption, with explosions following one another in rapid succession at a rate of 65 per minute (pl. $32 A$ ). The ejected material was stretched viscous masses of lava that were torn into several discrete bombs during flight. A cone had begun to form by the accumulation of ejected material about the vent, but at this stage inclosed only an arc of about one-sixth of the circle to the southwest of the vent. This wall was steep and about 15 meters high. A second orifice, about 50 meters from the main vent, erupted at intervals of 5-30 minutes with a sound like a locomotive starting. With each period of activity it emitted a few puffs of yellowish-brown fumes, or dust, and then subsided. About 20 meters southwest of the main vent was a slitlike orifice, aligned and sloping toward the main vent, that erupted every 4 or 5 minutes, throwing out viscous lumps of lava which plopped onto the ground. A white steaming crack extended from the crater rim to about twothirds of the way down the slope of the cone. ${ }^{18}$

At the end of 4 days of activity the small upper vent on the flank of the cone ceased its explosive activity, but its locus remained evident for many days afterwards as a small ash-covered knoll, stained yellow and white with fumarole products and from which arose a gentle curl of vapor.

${ }^{18}$ From notes of David Gallagher, U. S. Geological Survey. 
The remaining vent, now christened Sapichu, continued to eject viscous bombs without cease and to build its cone. Great quantities of lava continued to pour from its throat in surges that were sporadic but continuous enough to maintain an open breach on the northeast side of the new cone. At no time in its history did Sapichu assume a completely conical shape. From the very beginning to its last day of existence, it was always a lune-shaped "cone." During Sapichu's first days its crest was of irregular and changing outline, depending on the vagaries of explosion and slumping. On October 23 it had a low, semicircular form with a ragged crater rim. This rim was somewhat lower at the head of the cone where the ejected bombs from the vent scoured the walls. This sag was flanked by two small earlike peaks. As the cone grew and gained stability, it assumed a more regular form, eventually becoming a smooth horseshoe. A series of parallel steaming cracks formed on the main cone above this vent.

Ordóñez (1945) states that on the morning of October 23 (8:05 a. m. October 22, according to Gallagher ${ }^{19}$ and Storm ${ }^{20}$ ) a new vent opened on the outside flank of the main cone, about 50 meters below the northeast rim of the crater (pl. $32 B$ ). From it, dense black ash arose in small cauliflowers, with a noise like the escape of air under high pressure. The actual vent had a diameter of about 6-10 meters. Its eruptive column rose 80 meters and mingled with the vapors from the main crater. Gallagher describes the eruptions as exploding about 60 times per minute, yielding huge volumes of dark-gray ash, and the column as rising in cauliflower volutes. The outbreak continued, with a few pauses of variable intervals, until early afternoon. Gallagher places this vent on the line of the steaming crack observed 2 days earlier on the slope of the cone above Sapichu.

The area around this new vent, or chimney, and the cracks below it later developed by subsidence into a smooth-sloped swale of hot and muddy ash, spotted with patches of white, yellow, and greenish salts.

\section{ERUPTIVE ACTIVITY OF SAPICHU}

From the first day until Sapichu began to show some diminution in its explosive activity in late December, eruptive activity was notably constant and regular. The lava flow, although showing some variability, was continuous. Explosions from the vent occurred at fairly regular intervals, almost one each second, hurling viscous lava to a maximum height of 300 meters. These bombs appeared incandescent even during daylight. This fountain of incandescent bombs illuminated the environs of the cone at night and presented a magnificent spectacle. With rare exceptions the ejected bombs were all of one type, an inflated vesicular sponge that was shiny black inside and dull,

\footnotetext{
${ }^{10}$ From notes of David Gallagher. $\quad{ }^{20}$ From photographs by Lyn Storm.
} 
dark olive brown outside. The larger bombs were sufficiently viscous to flatten somewhat upon impact with the ground, and coins could be forced into them to yield souvenir pieces. This type of bomb was so characteristic of Sapichu that we referred to them and other similar ejecta as Sapichu type. A very rare and curious type of bomb, not observed at any other time, was a dense nodular mass without gas cavities. They showed small olivine phenocrysts in an aphanitic groundmass.

The characteristic ash of Sapichu was dark brown, very spongy in texture, and frequently of a dendritic structure. Fine filaments of glass were common in this ash. Bombs of xenolithic material were more common in the ejectamenta of Sapichu than in that from the main cone and showed a greater degree of fusion. Ordóñez ${ }^{21}$ reports that on November 20 the amount of this ash was so great that the ground around Sapichu was covered with a light-colored mantle resembling snow, but we were unable to find such a layer by digging a pit in the ash. These erratic bombs are evidently fused masses of diorite from the underlying basement rocks. The smaller fused fragments were very vesicular and snow white. They usually showed unfused quartz grains within the vesicular masses. Larger fragments were similarly fused, although some of the larger bombs were only partially so.

In remarkable contrast to the activity of the main cone, Sapichu showed no visible eruptive column, other than the ejected bombs. Bluish-white vapors, or rarely rusty-brown fumes (or dust), rose from the vent but were soon dissipated into the atmosphere. If atmospheric conditions were propitious, the emitted vapors condensed some hundred meters above the cone, forming a "tail" which widened upward into a white cumulus cloud (pl. $33 B$ ). It was evident from the volume of these clouds, some of which covered a large part of the visible horizon, that a great quantity of condensable vapors was being discharged from the eruptive vent. The rare times when one observed ash in the rising column were short intervals following a brief quies. cence, usually no longer than 10 seconds, during which a thin brownish or dense black column arose to a height of a few hundred meters. During these brief and rare periods a vesicular red or black cokelike ash fell sparingly.

No lightning discharges were observed in the emissions from Sapichu.

During Sapichu's period of eruption the crater of the main cone showed very reduced activity (pl. $33 A$ ), and there were times when no visible vapors arose from its crater. Two vents were still apparent: a central one, which sometimes showed mild explosive activity, and one near the northeast rim, from which only languid white clouds arose.

${ }^{21}$ Oral communication. 
Few incandescent bombs could be seen during the nights. Such bombs as fell outside the crater were an assorted lot: irregular aphanitic fragments, scoriaceous lumps, welded masses of small agglomeratic fragments, and a few round concretionlike bombs of aphanitic lava, suggesting that in spite of its reduced activity viscous lava was still present in the throat of the vent. The noises from the crater, too, were much diminished, the only sound audible at the camp being a subdued thundering rumble.

The following discussed days may be considered typical of the period of the life of Sapichu.

November 28, 1943.--The cone of Parícutin was regular except for a smooth steamy swale that extended down from the northeast crater rim. The main crater showed two vents, one in the center of the cone and the other near the head of the swale. Activity in both vents was much reduced, and there were times when nothing rose from the crater. A column of vapor, with little ash, ascended lazily, with little or no explosive force. Only white fleecy clouds of water vapor ascended from the northeast vent, usually to a height of not more than 50 meters. These emanations, white and billowy, like cumulus clouds, indicated a constitution of almost pure steam. The column from the south vent was sometimes white but frequently pale gray, indicating some admixture with ash. Rarely, cauliflowers or volutes arose lazily from this vent. Light vapors rose from cracks in the ash in the swale on the northeast slope of the cone.

Bomb bursts were rare and weak, and almost nothing fell upon the outer slope of the cone. This contrasted strikingly to the highly explosive and spectacular eruptions of the preceding few months when great columns of incandescent bombs rose to great heights and showered over the surrounding terrain. Now hardly an incandescent stone was seen above the crater rim.

Sapichu at this time was about 80 meters high and continued to maintain its horseshoe shape open to the northeast, in the direction in which the lava flowed.

The explosive bursts of Sapichu followed one another in rapid succession, averaging about one a second, with stronger explosions at irregular intervals, several per minute, that shook our cabin strongly. The explosions threw up a spray of viscous lava fragments that appeared incandescent even in the daylight. A column of tenuous vapor of gray brown (the color of nitrous oxide fumes) rose from the crater. With these vapors were fumes of bluish white that soon dispersed through the slowly rising column of gases. No condensed water vapor was visible.

The ejected blocks were of all sizes, up to about 2 meters across, and were plastic, changing shapes or being torn apart in their flight 
through the air. The solidified bombs were almost all of one typeirregular in shape, frequently rather round or flattened, very slaggy, almost spongily vesiculated, and powdery cinnamon brown on the outside and shiny blue black on the inside.

The lava flow was very large and had the appearance of a jumble of blocks and clinkers. Little of the moving lava below the clinkers was visible.

Whirlwind columns formed over the hotter portions of the lava during the day, some rising to a height of several hundred meters and persisting for 10-15 minutes.

For a few minutes in the morning, segments of compression waves, owing to the explosions, were visible in the rising vapors from the vent, following each other in rapid succession. Occasional weak waves were observed during the day, but none was seen at night.

Occasional flashes of lightning were noted in the eruptive column of the main Parícutin crater, and there were rare bursts of incandescent ash and very few bombs.

November 29.- Ash clouds from the main crater rose lazily and drifted to the northeast, but the activity was erratic and the cone sometimes inactive, with no ash and almost no steam emitted.

Sapichu showed its usual constant activity, except for one very brief pause of about 10 seconds, during which some ash rose from its vent. The explosive sounds in the vent came in a series of rapid sharp puffs interspersed with loud blasts. We timed the rate of fall of the highest bombs; these took 9 seconds to fall from their highest point to the ground ( 400 meters).

At $6 \mathrm{p} . \mathrm{m}$. the rising vapor column from Sapichu showed some condensation about 500 meters above the vent, where it formed a small cumulus cloud.

November 30.--Strong winds from the southeast raised dense clouds of dust, and there were heavy clouds in the east, southeast, and south; fewer, to the north.

During early morning a low gray vapor column rose from the main crater, changing at $11 \mathrm{a} . \mathrm{m}$. to pure-white vapors. These white vapors continued until $2 \mathrm{p}$. $\mathrm{m}$. when they again changed to a dense lightgray cloud that spilled over the west rim of the crater and settled to the base of the cone. At this time we encountered a light fall of mud. In about 15 minutes fog settled over the cone, almost obscuring it from view; and a faint odor of hydrogen sulfide was perceptible.

The activity of Sapichu was constant and regular. Besides the usual bombs, it threw out a pale-olive-brown dendritic ash, with a very little black and red cokelike scoria, and some snow-white vesicular fragments of fused diorite. There appeared to be two extremes of explosion. One, directed upward, yielded a bomb column shaped like 
a compact cedar tree and was presumably from explosions within the vent; the second was a burst of bombs radiating in all directions and apparently from explosions at the surface. By far the greater number were intermediate in form, yielding a fan-shaped burst of bombs. During midafternoon, there were several short bursts of black ash from the vent. These ash bursts always occurred rarely, followed a brief pause in the explosive activity in the vent, and contrasted strikingly to the almost ashless normal column.

At a station on the northwest flank of the main cone and about 150 meters from Sapichu itself, distinct tremors could be felt following each explosion. The maximum intensity of these tremors followed a zone from the vent of Sapichu to the main crater. At this same station I could detect a faint odor of sulfur dioxide in the fumes wafted from Sapichu.

At 2:45 p. m. a series of compression waves was apparent in the rising gas column, although the explosive activity in the vent showed no increase in intensity from its normal condition.

During the night, we felt many weak tremors at the cabin and occasionally detected an odor of hydrogen sulfide.

December 1.-The morning was cloudy but with little ash in the air and no wind.

The vapor column of Sapichu rose to a height of about 1,000 meters and condensed to a dense cloud that hid the sun. The eruptive column of the north vent of the main cone was white and billowing, followed in the evening by a dark-gray column from the south vent.

In the afternoon a strong wind raised such dust that the volcano was obscured from view, and at night it rained.

December 2.-Most of this day was spent south of the cone. Returning, we came to Sapichu about $3 \mathrm{p}$. m.; and, the wind blowing towards us from Sapichu, we could distinctly smell sulfur dioxide. Sapichu continued to throw out its usual type of bomb and characteristic dendritic ash.

From the slopes of the main cone, we could look down upon a fumarole yielding copious steam and located about 100 meters from the base of Sapichu. With almost every explosion from the vent of Sapichu, a compression wave could be seen distinctly through the fumarole's steam. During the evening and early night, fog drifted in from the west and hung about 100 to 200 meters above Sapichu. Numerous compression waves were visible flashing through this blanket of overhanging vapor.

Activity from the main cone was very weak until evening when there was an increase in the volume of vapor and ash.

December 3.-The sky was overcast with dense white clouds, and there were showers during the day. 
Rather dense gray vapor clouds came from the south vent of the main crater, and billowy white vapor clouds, from the north vent, and wisps of vapor drifted about the upper part of the cone; the eruptive column rose lazily and without bombs.

There was no change in the eruptive activity of Sapichu. The vapor column condensed into a gray cloud about 700 meters above the vent.

December 4.-A trip was made with Luis Aguilar to the east of Sapichu, and a place was found along the edge of the flow where the lava front could be climbed to the top of the flow. The surface of the lava was a jumble of dark-gray blocks and clinkers mottled with oxidized brick-red patches. From this desert of rocks rose an occasional crag or irregular ridges of twisted lava.

The lava front differed from place to place. Usually it was a steep slope of advancing rubble made up of gray or red lava fragments which rolled down the slope as the front advanced, raising clouds of pinkish-brown dust. Moving lava could be seen between large blocks of chilled lava, bulging slowly and fissured by incandescent cracks. Where massive lava was exposed, it formed dark-gray twisted blocks with a harsh pimpled surface.

Here and there one saw on the surface of the flow huge craggy masses of oxidized, loosely consolidated blocks of lava making up a rubble that resembled a coarse tuff. These appeared to result from the disintegration of chilled lava blocks. There were also mounds of welded bombs, sometimes a kilometer or more from the vent, that were portions of the cone of Sapichu carried away by the moving lava stream.

On the trail back, we met Sr. Arnaldo Pfeiffer, of Morelia, and Sgt. José Rosales, stationed at San Juan Parangaricutiro, on their way to the summit of the cone, which they reached about $4 \mathrm{p} . \mathrm{m}$. Upon his return, Sr. Pfeiffer reported that the swale below the northeast rim of the crater was muddy and hot with rising steam, necessitating a wide detour to avoid this impassable quagmire. A broad area covering this portion of the cone was streaked and colored with patches of orange, yellow, and white salts. This area, it should be noted, was the locus of the ephemeral vent of October 21. Sr. Pfeiffer reported that the crater rim was sharp. He was unable to see into the crater because of the copious emission of steam.

December 5.-There were scattered clouds and strong southeast winds today and more than usual activity from the south vent of the main crater, with a billowing light-gray column, sometimes rising to a height of 500 meters and then drifting toward the northwest. The north vent showed only mild activity, consisting of low drifting vapor clouds. Activity from Sapichu was normal and regular. 
In the afternoon we went to the east side of the lava flow, accompanied by Mr. Igor Sikorsky and Sr. Manuel Guzmán. We climbed the lava front and were able to approach within 300 meters of the open flank of Sapichu and to observe the character of the cone and the nature of the activity. The interior of the crater was a steep wall of semiconsolidated lapilli. The walls were continuously bombarded by molten bombs, and the lower walls and flow were veneered with viscous lava, which flowed slowly back to the vent. Occasionally a large slab of very viscous material would slide from the wall, exposing an interior of golden-yellow incandescence. There was but one explosive vent from which the lava issued continuously as a flow, and the escaping gases hurled viscous incandescent masses of lava into the air as an almost continuous fountain of "fire." The vent emitted copious white fumes.

The harsh grating roar of the explosions once ceased for a few minutes, and a tenuous brown dust billowed up, but incandescent bombs continued to be ejected without change. One tremendous blast threw huge masses of viscous lava against the crater walls.

In front of the vent was a breached wall, made up of welded incandescent bombs. It was slowly broken into huge segments which were carried away by the slowly moving lava stream, riding along like ships on a river.

Compression waves were visible in both the vapors rising from the crater and in the steam of nearby fumaroles and could be correlated distinctly with the explosions in the vent.

According to Luis Aguilar, ${ }^{22}$ Sapichu was still in continuous activity on January 5, 1944, but the force of its explosions gradually diminished until it was a mere vent of spattering lava. On January 6 the activity ceased completely.

\section{CRATER OF SAPICHU}

On January 8 we entered the crater of Sapichu for the first time and approached within 30 meters of the vent itself. The orifice was about 1 meter across and located upon the summit of a low lava mound. Sparse bluish-white vapors arose from the orinice, and occasionally a sudden belch of gas threw out a few small incandescent fragments of lava.

On January 10 activity in the crater of Sapichu was completely extinct, and we were able to examine the whole apparatus in detail. The vent, about 1 meter in diameter, was at the base of the south inside wall of the cone, which was about 50 meters high. Peering into this 
vent to a depth of about $2 \frac{1}{2}$ meters, we could see tenuous fumes issuing from incandescent crevasses, but there was no distinct odor about the orifice. The lava of the vent seemed distinctly massive.

The walls of the crater were made up of semicompacted bombs and had angles of slope up to $60^{\circ}$, but rocks were almost constantly sloughing off to form a talus fan at the base. Above the eruptive throat and to the right was a low cavelike overhang. This cave and the walls immediately above the orifice were veneered with smooth massive lava for a distance of about 15 meters above the vent. Above this were steeply dipping lenses of massive rock 15 to 25 centimeters thick, evidently huge masses of viscous lava thrown against the walls during violent explosive bursts. There were also steeply inclined slickensides where slabs of viscous lava slid off the walls, as we had observed on December 5. At the horseshoe ends of the cone, the walls were made up of loosely compacted broken bombs. The bomb material was coarsely stratified with the beds dipping toward the axis of the horseshoe. The eastern limb of the horseshoe was broken into blocks and separated by crevasses where the flowing lava had begun to carry away blocks of the walls.

The lava in the crater consisted of twisted slabs of semivesicular rock, covered by scoriaceous and slaggy bombs. Several terraces were discernible, evidence of several distinct lava surges.

With the cessation of the eruption, activity in Sapichu completely ceased and was never resumed. Not even fumarolic vapor arose from the vent. In time the sloughing of the walls reduced the crater to a semifunnel, with walls of about $35^{\circ}$.

In November and December 1947, lava flows from the Taquí vents covered the last remaining traces of the Sapichu cone.

The lava flow of Sapichu greatly exceeded any of the previous lava flows; in fact, exceeded all the previous flows combined. It covered an area of more than 3 square kilometers and had an estimated weight of 38.5 million metric tons. It completely covered the Lagunita flow (June-July 1943) and a part of the Quitzocho flow (February-March 1943) as well as the lands of Corúnguaro, Turímbaro, Jarátiro, Titítziro, Churingo, Terúpicua, Tipacuaro, Cheraquijando, Piedra del Sol, Nitzicátaro, Chorétiro, La Lomita, and El Pajarito, extending to and in places crossing the San Juan Parangaricutiro-Uruapan road (pl. $43 B$ ).

The lavas showed the same characteristics as previous flows, both in type of material and in their advance as a steep-walled rubbly front. The surface of the lava flow was the usual confused jumble of dark-gray blocks, profusely mottled with oxidized patches of brick red. Spires or towers of breccialike material rose here and there above the general 
level of the flow, and irregular ridges of twisted lava could be seen.

Only a few persistent fumaroles developed in the Sapichu flow. Most of these were localized along a scarp where the Sapichu flow poured over the old front of the Lagunita flow onto the ash-covered fields of La Lagunita (pl. 45A).

The ultimate front, at the San Juan Parangaricutiro-Uruapan road, about 3 kilometers northeast of its vent, formed a scarp about 10 meters high (pl. $43 B$ ) made up of blocks of disintegrated lava and scoriaceous clinkers of all sizes. The largest block observed had a volume of about 300 cubic meters. Crags of solid lava protruded from the rubble but showed no flow surfaces.

With the cessation of activity at Sapichu, the main crater resumed its normal explosive activity; the eruptive column rose in successive cauliflowers with the ejection of considerable ash and bombs and the usual noises.

\section{CRATER OF THE MAIN CONE}

During the reduced activity of the main crater, the cone was ascended for the îrst time, by Sr. Arnaldo Pfeiffer, veteran alpinist of Morelia, on November 3; and Sr. Pfeiffer, accompanied by Sgt. José Rosales of the Mexican Army, stationed at San Juan Parangaricutiro, made another ascent on December 4. Pfeiffer reported that the area below the low northeastern rim was very muddy, hot, and steamy. The crater rim was very narrow, not more than a meter wide; but he was unable to see into the depths of the crater because of the copious vapor clouds that filled it.

On December 19 an ascent was made by Srs. Abraham Camacho and Celedonio Gutiérrez who reported that the crater was funnel shaped and its steep walls were covered with small and large black rocks. In the bottom of the crater were three small funnel-shaped vents, oriented east-west. Vapors issued from these vents, sometimes simultaneously, sometimes alternately. A large fumarole, located on the eastern wall of the crater, emitted abundant vapors. About this fumarole the walls were encrusted with white and yellow sublimates. At that time the cone had an elevation of 345 meters above the level of Quitzocho (Ordóñez, 1945).

Luis Aguilar and Sgt. José Rosales ascended the cone on January 5, 1944. At that time the crater had the form of a shallow dish. The crater contained five funnel-shaped vents, the principal one near the southwest edge of the crater. A very strong odor, described by Aguilar as the odor of the gases of the hornitos (hydrochloric acid), pervaded the crater; and there were abundant yellow sublimates within the crater. During their stay on the rim the volcano began to thunder and give off puffs of black smoke; whereupon they came down very quickly. 
Sapichu and its accessory vents broke out along the line of the small fissure that appeared at Llano de Cuiyúsuru during the birth of the volcano on February 20. This apparent line of weakness includes, besides Sapichu and its accompanying vents, the main crater vent and the vents of the Mesa del Corral flows on the opposite side of the cone. This last vent, which we later called the Ahuán vent, became an important locus of later lava flows. This line was also a marked tremor zone. Sapichu, therefore, evidently occupied a position on one of the important fissures of Paricutin volcano.

Sapichu throughout its entire life showed only a strombolian type of activity, because the explosive activity took place at the summit of a continuously rising lava column where it was unimpeded by any overburden in the throat. In many respects Sapichu showed the characteristics of the main volcano during its early stage, but with these important differences: its explosive activity was less violent but more regular and its lava flow much larger and more regular. The greater explosive capacity of the original vent and the greater abundance of fumaroles in the Quitzocho flow suggest that the gaseous content of the Sapichu lava had decreased from that of the earlier flows. The quantity of ejected diorite blocks was much greater from Sapichu than from the main cone, and the blocks showed a greater degree of fusion.

Although there may have been some pauses in the emission of lava from the Sapichu vent, they were not directly observable, the flow of lava being essentially continuous. This is in contrast to the Quitzocho period when lava flowed from the main vent in frequent surges and even in individual flows. Because of this continuous flow of lava from Sapichu, its "cone" was never complete and always maintained a horseshoe shape; for the flowing lava stream continuously carried away the accumulating bombs from its northeast side. Masses of these bombs were later found a kilometer or more from the cone, where they had been carried by the lava stream. In the Michoacán basalt province, there are a number of such cones, some of which undoubtedly had a history similar to that of Sapichu.

This horseshoe shape allowed clear observation of the character of the explosions in the vent. These explosions took place at the top of the rising lava column or at depths of no more than a few meters below the surface. The explosive activity also clearly showed that a vent free of accumulated debris or of slumping from the sides of a funnel-shaped crater yielded an eruptive column free of dense ash or triturated material. The ejectamenta from the freely rising lava column consisted of vesicular spongy bombs or shredded ash. The eruptive column yielded by such a rising lava is tenuous, consisting 
largely of invisible water vapor that, when atmospheric conditions are appropriate, condenses as cumuluslike clouds far above the vent.

One of the more remarkable features of Sapichu was the relatively small diameter of the vent. The lava vents in later flows were not large, but in none was it so small as at Sapichu. Its vent, hardly more than 1 meter in diameter, was capable of supplying a lava front more than a kilometer across and about 5 meters high and maintaining this front in a state of continuous, if slow, advance.

This lava flow was of the same nature as the previous flows. The total area covered by the Sapichu lavas was found, upon measurement, to be $3 \frac{1}{4}$ square kilometers. The lava differed very little, chemically, from the lava of the previous period.

Although it was evident that Sapichu occupied a position on a fissure, it showed no apparent change of location or movement along this line and remained fixed throughout its life. The fact that its cone showed no appreciable change, other than those incident to its growth, tends to confirm this observation.

During the life of Sapichu, activity in the main crater was considerably reduced, yielding a light-gray eruptive column from a central vent and white vapors from a vent near a northeast rim. For a day during the early period of Sapichu, a vent on the northeast slope, corresponding to the lava vent of the Lagunita flow, sent up an intermittent eruptive column.

\section{TAQUY PERIOD}

\section{TAQUí VENTS}

With the cessation of eruptions at Sapichu, the locus of active lava vents changed to the southwest base of the cone, and the eruptive activity of the main crater greatly increased. By January 8 , when the last dying gasp of Sapichu was observed, the main crater was again in full activity, with a billowing eruptive column rising in well-formed cauliflowers to considerable heights. Ash began to fall again in perceptible amounts in the form of brownish corky grains, cokelike fragments, or as small flaky spalls. Bombs, too, again fell on the cone in abundance. These consisted of dense, rounded congealed masses, semiscoriaceous platy masses, or irregular blocks of agglomerate of partially welded fragments. Explosive activity appeared to be localized in the southwest, or main vent of the crater. Explosive noises were rare, the sounds accompanying the activity being the surflike noise characteristic of heavy bomb activity.

About midnight on January 7 a bright-pink reflection appeared over the southwest base of the cone, indicating the presence of incandescent lava in that vicinity. The next morning revealed 2 new lava vents from which 2 active flows issued (pl. $35 A$ ). These vents were, 
as near as we could determine, at the locus of the small and shortlived vent of August 26, 1943 . They were destined to be the most persistently active of any of the lava vents and to yield the greatest of Parícutin's lava flows. The 2 vents were about 25 meters apart and separated by a crevassed and bomb-spattered septum of congealed lava. The north orifice occupied the head of the narrow steepwalled trench formed by levees of congealed lava. This vent was surrounded by an aureole of spatter bombs. The lava in the vent was in a state of continuous ebullition, the incandescent lava spattering up to a height of 10 meters or more; and incandescent lava coursed rapidly, at an estimated rate of 1 meter a second, down the leveebordered trench. The second, or south, lava vent, also at the head of a narrow trench, was more erratic in its behavior, sometimes spattering violently and sometimes flowing quietly but copiously down its self-made channel. There was an apparent connection between these two vents. When the south vent entered a state of violent ebullition, the activity of the north vent diminished or was even reduced to a quiet flow. From both vents and the flowing lava, bluish fumes arose, sometimes tinged with brown; and a strong odor of hydrochloric acid was evident about the vents. These vents we called the Taquí vents; and the flow that issued from them, the Taquí flow.

Above the lava vents was a bulge in the slope of the cone, surmounted by a narrow terrace about one-third the way up the cone. This smooth bulge of ash was traversed by a series of small cracks from which white steam issued continuously; and the whole bulge was moist with condensed steam, contrasting with the dry ash slopes surrounding it. In the ash on the terrace directly above the south lava vent was an orifice, about 3 meters in diameter and of unknown depth, from which issued dense white steam clouds.

The lava as it flowed from the vents changed rapidly from bright incandescence to a black stream dappled with glowing spots. Overlapping tongues of different stages of incandescence suggested that the emission of lava was not entirely regular and occurred in surges which followed one another in rapid succession (pl. 35A).

By the next day, January 9, the lava vents had changed some. The north orifice remained in constant ebullition, but the south vent flowed quietly, without spatter. The south orifice and a third vent observed behind it were separated by the rugose lava septum. This vent may have been present on January 8 but not sufficiently active to have attracted attention. It was very erratic in its activity, spattering lava at rare intervals. The steam orifice above the vents showed increased activity, giving off an occasional short burst of ash-laden steam, and in midafternoon showed an almost continuous $3386690-55-7$ 
activity, emitting a small ash-laden eruptive column and ejecting some small bombs (pl. $35 B$ ).

On the lower slopes of the cone, immediately south of the vents, the ash showed crevasses from which steam with a strong hydrochloric acid odor issued. The ash about these crevasses was stained with yellow alteration products. The north lava vent made little noise other than a faint "shu-uh shu-uh," and the south vent was quiet except for a rare low "chu-chu-chu." These sounds we had learned to associate with a rising lava column.

The lava from the two vents flowed rapidly down the low slope into the small valley formed by the cone and the east slope of the Mesa de Cocjarao. Although the general land slope was toward the north, a low ridge blocked the flow of lava in this direction, diverting the stream to the south and along the southwest base of the cone. The lava flowed freely from the vents and had a crude ropy surface, rather distinct in structure from any of the previous lavas, but the advancing front presented the characteristic jumble of clinkers and lava blocks shown by the previous flows.

Directly opposite the vents, on the lowest slopes of the Mesa de Cocjarao in lava-free terrain, we found a fissured and displaced ash zone about 200 meters long and 100 meters wide, extending from the lateral slope of the lava to the foot of the Mesa itself (pl. 34B). This zone had a strike of N. $50^{\circ} \mathrm{E}$. Vertical displacements in the fissures of this zone did not exceed 30 centimeters. This unusual development of fissures in original, tree-covered terrain was unique in our experience at Parícutin. Later we were able to discover that this belt was also a zone of distinct tremors or, as we called it, a tremor zone. (See fig. 123.) This zone corresponds, as near as we could determine, with the direction of one of the original fissures that appeared on February 20, 1943.

On January 10 two distinct earthquake shocks were felt, one at $2: 10 \mathrm{p} . \mathrm{m}$. and another at $2: 35 \mathrm{p} . \mathrm{m}$. Later inquiry showed that these shocks were felt and recorded in Mexico City and that their epicenter was in the State of Guerrero and therefore had no close connection with Paricutin volcano. These shocks induced no evident change in the activity in the crater or in the lava vents.

\section{TAQUí LAVA FLOW}

According to reports, the first flow of lava from the Taqui vents continued until January 12 . On February 6 these vents reopened and again poured out lava. By February 10 when we again visited the spot, we found it greatly changed from its condition of a month before. Many of these changes were evidently due to the accumulation of lavas, which was now great enough to submerge the vents of 
Taquí, so that lava no longer issued freely at the surface. The lava continued to issue from its original vents but flowed beneath a thick crust of congealed lava, following irregular and wandering channels, to appear eventually at the surface several hundred meters from the locus of the Taqui vents.

During the month that had elapsed since the outbreak of lava at Taquí, the lava stream had advanced around the south and east sides of the base of the cone, filling the valley formed by the cone and the lower northern flanks of Cerros de Tancítaro. The lava front, about a kilometer long and 3 meters high, reached a point near Sapichu where it debouched onto rolling pine-covered terrain and ignited the trees in its advance through the forest. This lava advanced much like previous flows, with bulging lobes of viscous lava near the base and clinkers and blocks rolling down the front, stirring up small plumes of pinkish dust. Although the terrain over which the flow moved was of low smooth ridges and shallow arroyos, the advance of the front was rather uniform, its continuity broken only in three places, where tongues of lava showed a more rapid advance down some small arroyos.

From February 10-13 the eruptive column was dense and heavily laden with ash, and westerly winds carried the dust far to the east as a dark low-hanging cloud. Beneath this cloud the fall of ash was heavy and frequently came down as a mud that coated the leafless trees.

From a high point on Mesa de Cocjarao to the southwest of the cone, one could obtain a good view into the crater through the lower rim on the south side. The principal eruptive vent, somewhat toward the south wall from the center of the crater, gave off a continuous voluting eruptive column, in which lightning flashes were distinctly observable, even in daylight. To the north of this vent, there appeared to be a second orifice which exploded intermittently. Although ash billowed incessantly from the crater, only occasionally were there a few weak bursts of bombs. The accompanying noise was a low surflike rumble, with frequent low thundering rolls.

The ash that fell during this period consisted of a brownish shredded slag, porous fragments with a crust resembling pine bark, black cokelike fragments, and flat angular spalls.

This point marks the end of the first year of Paricutin's activity, the important stages of which are illustrated in plate 15 and lava flows in figure 122.

On March 1 when we again visited Parícutin, we found the lava field about Taquí vent greatly changed. The lava now completely filled the basin lying between the cone and the lower slopes of Mesa de Cocjarao and had surmounted the saddle that connected to two; 


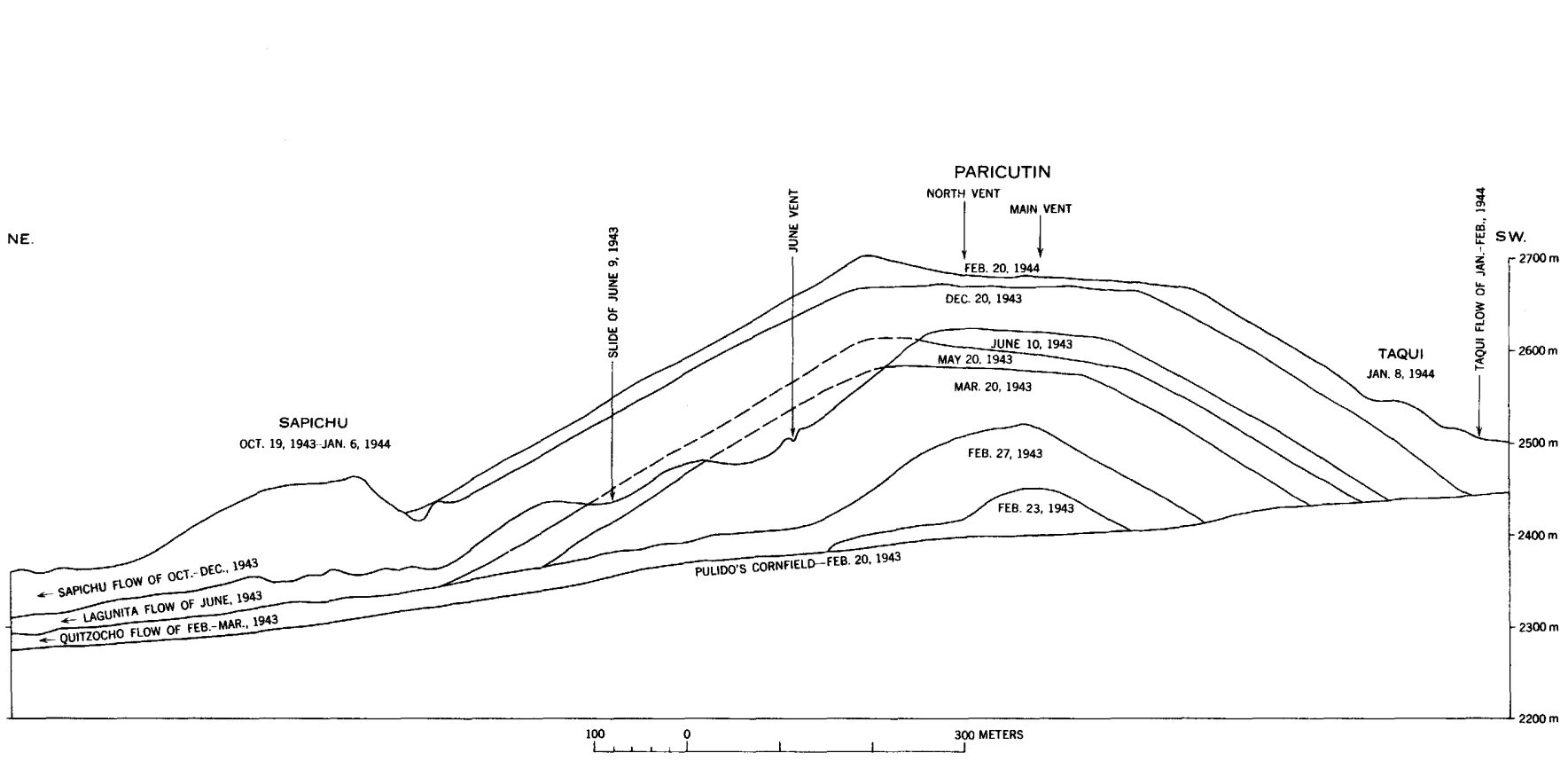

FIg URE 122.-Paricutin volcano, showing its important stages of growth during the first year, February 20, 1943, to February 20, 1944. Northeast-southwest cross section. During the first year's heavy cineritic activity the cone reached it full growth. 
but, except for a short cold tongue of lava toward the north, the lava still continued its old course along the south base of the cone. In place of the active flowing vents, which were now deeply buried under the accumulation of flows, we found three steeply conical peaks with vertical shaftlike craters which Ordónez (1943) called volcancitos (pl. $37 B$ ) and a great number of low irregular pinnacles of vesicular lava, or hornitos upon the congealed surface of the lava. Bluish vapors arose from summit vents of the volcancito, the irregular openings in the hornitos, and the fissures in the lava, and a strong odor of hydrochloric acid pervaded the vicinity. A wide area was brilliantly colored by an orange-yellow incrustation, imparting a weird, colorful beauty to this otherwise bleak and depressing landscape. A loud hissing, like the escape of steam from a number of vents, could be heard from some distance away.

At or about the locus of the original Taquí vent was a tall, slender volcancito, and nearby to the west was another asperous dome-shaped one, with a wide incandescent throat in its western flank. Still farther to the west was a steep conical volcancito with a glowing open mouth near its summit, and adjoining this was a smaller one, crusted on its southern side by a small rough tongue of lava. Nearby was an open cavelike throat in a low domelike eminence, which showed a number of incandescent crevasses and hissed particularly loud. About this line of volcancitos was a zone of fresh rough clinkery lava which had evidently only recently flowed over the older ash-covered flow. Beyond the volcancitos the zone of hornitos followed the course of the lava stream (pl. 36B). Here were dozens of these remarkable hornitos, but the abundant strong and choking fumes prevented an examination of them at close hand. Later we were able to study them in detail and even had the opportunity to see one grow. In addition to these pinnaclelike hornitos, one could observe numerous small warty excrescences of lava, usually less than 2 meters across, upon the old lava surface. Like the larger hornitos they showed small incandescent orifices, and they were, undoubtedly, low forms of the more conspicuous hornitos.

On March 3 we first observed flames from both the volcancitos and the hornitos. At dusk a faint-violet flame was perceptible, waving like a tenuous banner above the orifice of one of the volcancitos. Then similar flames were observed above the wide orifice of the largest volcancito and finally flames from orifices in the lava crust. Occasionally small incandescent stones were ejected from these vents. Within the area of the volcancitos, one could see that each incandescent orifice of the hornitos was likewise yielding flames and that the strong hissing, so apparent in the area, was due to the escape of the gases associated with these flames. The flames appeared pale 
violet in the light of dusk, but at darkness appeared pale blue and tinged at their edges with yellow. Above the large flames arose bluish-white fumes, or vapors. The flames from the volcancitos rose continuously in waving tongues, the larger ones rising to a height of 2 meters above the orifice. In the spacious orifice of the largest volcancito, the flames burst forth spasmodically at frequent intervals, like a flash or ball of pale fire. From the hornitos and low excrescences, the flames shot out with a continuous hissing like small blowtorch flames. The small vents from which the flames issued were lined with a thin coating of fused but viscous lava, which suggested a refusion of the lava by the heat generated by the burning gases.

On March 4 the crater had a symmetrical interior sloping to a single relatively small central vent. No evidence of a second vent was apparent. Small wisps of steam arose from the crater rim.

From the air, no flowing lava could be observed about the Taquí vent; but about one-half a kilometer downstream, a ribbon of red glowing lava apparently issued from beneath a lava crust. This stream showed continuous incandescence for about 300 meters, where it changed to a winding black river, moving over older gray lava.

The lava flow itself had not only advanced considerably since February but had also increased in thickness. The main front moved slowly, but at frequent intervals tongues of lava broke out from the rubble-covered face, forming outliers of twisted and crevassed black lava quite distinct from the more characteristic blocky form of the main mass. These tongues appeared to be essentially solid but yet showed some slight creaking advance.

On the evening of March 6 occurred a most spectacular outbreak of lava fountains on Mesa de Los Hornitos, above the buried Taquí lava vents. Dr. Frederick H. Pough has given us an account of this event:

Te Ata, Luis and I went around to the far side of the volcano [west] to photograph the blue flames at close range. We crossed the older lava dotted with hornitos and came close to the foot of the cone. At this spot a ridge 100 feet high and with two humps each about 30 feet high extended toward the' west. A saddle about 5 feet lower separated them, and a second saddle, about 10 feet lower, joined the first hump with the main cone. The flow to the southwest was very jagged and since it was still hot was impossible to cross, so that the cone could be circled only along its base. Coming to the ridge we attempted to cross at the lowest saddle where it met the cone, but found that we could not do so because of a fumarole emitting hot, acrid gas with considerable force. We crossed above it by climbing up the slope of the main cone.

Beyond the ridge were several hornitos and volcancitos. An isolated peak, about 25 feet high, showed a cascade of frozen black lava extending from its throat to its base. At the north side of a second hump there was a beehive volcancito with a similar but less well-formed lava cascade. Gas was being forcefully emitted by both these vents. 
That evening we found the volcano in only moderate activity with an occasional small bomb rolling down the slope. Since it was still light we dawdled around the base of the cone until it began to get dark. No particular or unusual activity was seen in any of the volcancitos, nothing to attract any special attention.

Shortly before seven, as it began to darken, it was decided that we might as well get to our station and prepare to photograph while we could see. Luis, carrying the tripod, led the group and as he surmounted the ridge he saw that the volcancito we had selected for the photographs had become very active and was emitting lava. A pool of lava had filled the throat and was beginning to overflow to the northeast. Gas was still coming out with force, making huge bursting bubbles, splashing fragments several feet in the air. The lava was not very fluid, and though the slope was considerable and the temperature high, as indicated by its orange color, it flowed with some deliberation.

The noise that accompanied this eruption was much like that of the plopping of a mud volcano, plus a hissing of the escaping gas. While we were watching this spectacular display we noted an increase in activity in the isolated volcancito behind us, which began to throw out a few gobs of molten matter.

The activity from the first vent continued, with occasional bursts from the nearer vent, but most of the eruption was concealed behind the ridge. It was not possible or safe to go onto the recent flow, so the only alternative seemed to be to climb on the main cone. As we started our climb we noted that minor activity was showing in several other vents, all throwing out rocks and casting a glow on the escaping vapors suggesting that incandescent lava was in the throats, and that the gas output had increased. The plan of going along the slope was revised when the small fumarole in the saddle began to throw out a few rocks. In a few minutes this vent became increasingly violent and soon lava welled up in its throat and began to spill over. Meanwhile the whole series of volcancitos which made up the complex of the ridge was repeating this overture, with lava spilling from several of them. In about ten minutes-it was now completely dark - a thrilling spectacle developed. The lava seemed to enlarge the vents and to expand into considerable-sized openings. Gas rushed out and breaking bubbles threw liquid fragments high in the air, probably 150 to 200 feet. The solid fountains of the lava were about 20 to 30 feet high, and above them the air was filled with flying fragments. The fountains cascaded down to form a flow, not very fluid but advancing in big ropy curds in a stream about two feet thick, ferrying cooler bits on its surface. Activity kept increasing and, although we were standing about 100 feet from the vent, the lava fragments soon began falling unpleasantly close. We decided then upon another retreat; salvaged our instruments from where they had been placed only a few feet in front of the advancing tongue and went further back on the old flow.

From this spot about 100 yards from the vents we had a magnificent view of seven simultaneously operating lava fountains, with the flowing lava merged into a single front advancing toward us over the older partially ash-coated lava. The sounds were still the same, the noises of a dozen mud volcanoes, with a plopping and a hissing and a little crackling from the cooling lava surfaces all merging into one amazing concert. Not all of the gas vents were producing lava. In some places holes were blown in the flowing lava by gas vents which were being covered as the liquid advanced. They looked dark, but were probably dark in the sense that sunspots look dark on the disc of the sun.

Gradually the eruption began to die down, the fountains diminished, and the fragments were no longer tossed so high in the sky. By 8:00 all but the vent in the saddle had ceased producing fountains. The whole spectacle lasted little more than an hour. 
On March 21 the area about the Taquí vents, now called Mesa de Los Hornitos, showed still further changes. Most conspicuous changes were in the volcancitos. The largest volcancito, which presented a wide open mouth on its south flank, was now a symmetrical cone about 15 meters high, with a deep chimneylike opening at its summit. From its summit vent arose pale-bluish fumes, and its throat was oxidized to a brick red bordered by yellow incrustations. The north side of the volcancito was tinged and colored with yellow salts. The neighboring volcancito, from which previously the biggest flames arose, was collapsed on its south slope. The orifice of its vent was likewise oxidized and altered, and faint-bluish fumes arose from it. The cavelike orifice was now less active than previously; and a small congealed lava flow, apparently from one of its own vents, covered the floor. It was now evident that this cavelike apparatus was a collapsed volcancito. On the floor of this old volcancito, a tall, slender hornito had formed rising slightly above the old rim. This hornito, which we called the Soplete, or blowtorch, because of its action, could be observed readily from a distance of a few feet from a station on the old volcancito rim. From its summit orifice, gases rushed with a hissing. Stones tossed into this orifice were immediately ejected by the rush of gasses. At night one could see a blowtorchlike flame of pale blue issue from its summit vent (pl. 37A). Sticks held in this flame were readily ignited. We succeeded in breaking off the tip of the Soplete and found it lined with brilliant spangles of hematite and delicate arborescent groups of magnetite.

Immediately west of the "cave" was a new feature, a "window" in the congealed crust where the flowing lava could be observed. David Gallagher ${ }^{23}$ had already observed this window on March 8. The window was about 3 meters wide, 12 meters long, and bordered at its head and lateral sides by a levee of scoriaceous lava, presumably built up by spatter from the flowing lava stream. The lava issued quietly from beneath the crust and flowed calmly, except for a low heaving motion, to disappear again beneath the crust at the lower end of the window. Its rate of flow was estimated at about 1 meter in 5 seconds. Bluish vapors with a strong acid odor arose copiously from the flow.

A considerable area north of the volcancitos was covered by a fresh flow of pahoehoe lava ( $\mathrm{pl}$. $36 \mathrm{~A}$ ), a lava form rarely observed at Parícutin. Ropy structure was not well shown; instead, the lava showed a flat, hummocky surface with a slaggy skin covered with fernlike streaks of stretched vesicles. The source of this pahoehoe lava could not be exactly determined but appeared to be the large cone-shaped volcancito.

${ }^{23}$ Personal communication. 
An unusual type of lava also observed at this time consisted of elongated ropy blocks, heaped together like logs of cordwood in a jumbled pile. The lava appeared to be closely associated with the pahoehoe flow.

During the night of March 21-22, the lava in the window ceased flowing and congealed, and the lava wall about the window collapsed. The large conical volcancito had also collapsed, yielding a depression about 20 meters long and 10 meters wide surrounded by the low domelike remnant of the original structure. The bottom of this depression was now covered with congealed lava, except at each end, where shafts with incandescent throats were located; each yielded bluish-white fumes. The Soplete and other hornitos between the volcancito and the window had also ceased their activity. This sudden cessation in activity suggests that lava had ceased flowing from the vent beneath the lava crust or that the flow was diverted into another channel.

\section{TREMOR ZONE}

Shortly after the outbreak of the Taquí vent, the Tarascans moved their refreshment stands from Cerro de Jarátiro to a broad terrace at the foot of Cocjarao Mesa, directly opposite Mesa de Los Hornitos, for the spectacle for tourists was now the ever-changing lava activity of the Taqui vents. This campsite became known as Campamento de Aurora. A few hundred meters to the south was the zone of fissures mentioned in the section entitled "Taquí vents." On March 22 we discovered quite by accident that this belt was also a "tremor zone." It was noticed that in the belt of the old fissure zone, the ground was in a state of varying but continuous trepidation which, however, was not perceptible 100 meters to one side or the other. The zone could be delimited by sitting at various points in the area or, as we found later, more easily by observing the tremor of the branches of the dead pine trees. A plumb bob suspended from a log partially buried in the ash clearly demonstrated the variations in the trepidations. This zone of tremors had a direction, as near as could be determined, of N. $60^{\circ} \mathrm{E}$. (magnetic) and coincided, as nearly as our information allowed, with the direction of the original fissure of February 20, 1943. The line of the volcancitos had a direction of $\mathrm{N} .65^{\circ} \mathrm{E}$. (magnetic). We have no evidence, however, that this apparent coincidence had any real significance.

A striking relationship between the variation in the intensity of the tremor and the explosive activity in the main crater was readily apparent. Although in general the trepidations were gentle and only apparent when one was seated somewhere along the zone, there were frequent intervals when the tremors suddenly increased and were relatively strong for an interval of less than a second. Three and a 
half to four seconds after these sharper shocks, an eruptive burst occurred in the crater. The estimated distance from Campamento de Aurora to the crater vent was about 1,000 meters. It was repeatedly noted after an unusual lapse of time without explosions that the next tremor would be relatively strong. One month later, on May 22, the tremor zone showed weaker but still distinct trepidations.

\section{CRATER ACTTVITY}

During March the eruptive activity in the crater was quite variable, ranging from a weak eruptive column with a deep rumbling to huge wooly cauliflowers rising in continuous succession but with little sound ( $\mathrm{pl} 38 A, B ; 39 A$ ). The active vent appeared to be very close to the southwest crater rim, which was lower than the north rim, presumably owing to the proximity of the eruptive throat.

On March 21 at 4:10 p. m. a strong earthquake shook the area. Immediately preceding the shock, the crater showed only mild activity. Directly after the shock, activity increased greatly; and large cauliflowers of pale gray developed rapidly but silently, or with little noise. Although the eruptive activity for the last several days was similarly variable and because the previous earthquakes induced no apparent change in the eruptive activity of the crater, it is more than likely that this apparent effect was purely fortuitous. There was also no apparent change in the activity of the volcancitos or hornitos.

During these days few bombs fell on the cone. The ash consisted largely of porous concretionlike masses, frequently elongated to resemble fragments of twigs. Some shredded ash, of the Sapichu type, also fell, particularly when the eruptive column was tenuous and the noise a deep-throated rumble.

During the night of March 25 the activity in the crater increased to violent proportions. About midnight a tremendous explosion showered Campamento de Aurora with huge bombs, causing the Tarascans to flee their posts in precipitous haste to Mesa de Cocjarao. Fortunately the bombs were channeled into a narrow zone immediately north of the camp, but they fell there in such abundance that hardly a square meter did not contain a large bomb, and they shattered every tree in the area. Numerous bombs were found a mile from the crater; and later we found one, more than a meter in diameter, nested in its crater in the ash on the summit of Mesa de Cocjarao. With this great explosive burst, the activity subsided. One effect of these heavy explosions during the night was to lower markedly the southwest rim of the crater.

The activity of the volcano continued with little appreciable change, except perhaps for a diminution of ash in the eruptive column. From this period on, the majestically rising eruptive column was 
frequently very pale, or even pure white, indicating a minimum amount of included ash. Sometimes the column rose, without visible vapors, as a tenuous cloud of pale-brown ash, accompanied by a deep, throaty rumble (pl. 39B). A pale-brown shredded ash, like that of Sapichu, fell sparingly during such an eruption. This suggests that the eruptive throat was open and not choked and that the rushing vapors abraded the open throat of its fused lining. At night when many bombs were being hurled out of the crater, the effect was particularly beautiful; for the incandescent rocks stood out clearly against the deep-blue backdrop of the sky unobscured by the rising vapors or falling ash, and a glowing reflection tinted the clouds above a deep, rich rose. Alternating with these periods of white eruptive column or tenuous ash were times when the column rose in its normal manner, ascending in voluting cauliflowers of dark gray.

On April 4 at 11 o'clock a strong earthquake was felt in the area.

\section{LUMinous PHENOMENA}

An unusual phenomenon observed on the night of April 5 should perhaps be reported here, although it admits of no ready explanation. While we were approaching our camp on Cerro de Jarátiro, on horse by trail from San Juan Parangaricutiro accompanied by several Tarascan horsemen, Foshag, who was well in the lead, saw what appeared to be a vivid flash of bluish light about the base of the cone. The base of the cone itself was screened from the view of the other members of the party by the ridge upon which the camp was located, but a few minutes later another flash appeared and was seen by other members of the party and caused one of the Tarascan horsemen, who had in the meantime advanced toward the head of the caravan, to cry, "Rayos por abajo!" [Lightning from below.] Observers at the camp reported having seen nothing, which led us to believe that the brilliant flashes were no more than an illusion.

On April 24 we observed another and definite curious luminescent phenomenon above the cone. This luminescence was first called to our attention by Ing. Ordóñez, who had seen it strikingly displayed the previous night and described it as "searchlights playing out of the crater." It appears that this unusual occurrence owed its origin, or at least its visibility, to a special disposition of centers of activity in the crater. A thin erect eruptive column rose continuously and without apparent force from a vent very close to the northeast edge of the crater. The night was still, without wind, but the upper currents of air carried the eruptive column lazily toward the east, revealing sparkling stars in the clear, cloudless sky in the area above the crater. A second vent near the center of the crater gave off single lazy bursts at intervals of one-half to an hour or more. The dust of the explosions 
from this second vent drifted slowly toward the west, in the direction of Cerro de Canicjuata. In the region where this dust cloud eventually disappeared, a dancing luminescence appeared, usually at a height estimated at 200-1,000 meters above the crater and extending well over toward Cerro de Canicjuata. This luminescence differed from the ordinary pink reflection of incandescent lava upon clouds or rising vapor by its bluish-white color, and in the fact that it persisted long after the ash cloud had dissipated entirely from view, and the stars were distinctly visible through it. Its appearances reminded one, in its movement and color, of the aurora borealis. It appeared most distinctly some time after an eruptive burst from the central vent and remained clearly visible until the next explosion occurred, alternately expanding toward Cerro de Canicjuata and then retracting toward the crater. We watched this spectacle for several hours, seeking some simple explanation for it. Less striking, but still well defined, was a shaft of light of similar appearance that followed the inner, or crater, side of the eruptive column. From Ordónez' description, it appears that the phenomenon showed itself even more strikingly the preceding evening.

\section{THE CRATER}

After the long period in which the crater showed persistent explosive activity, the volcano became somewhat more erratic in its action, and there were brief periods of consistently reduced activity when it was feasible to climb the cone to the crater rim. On May 22 activity in the crater was still normal; a full eruptive column rose majestically in full voluting cauliflowers, apparently from a centrally situated vent. But on the $23 \mathrm{~d}$, activity was reduced to a lazy, weak column, charged with a pale shredded ash, which on the 24th was still further reduced to a tenuous dust column with little visible vapor. On May 25 visible emissions had almost ceased, although a deep, low growl from the crater indicated that gaseous emissions were still being given off. Advantage was taken of this condition to make our first ascent of the cone and to perceive its shape and observe the character of its activity.

The crater was eccentrically funnel shaped, the southwest wall being steeper than the other slopes and the southwest rim lower. The western slope showed a narrow bench from the crater rim to a precipitous slope of semiconsolidated tuff, the bench being the remnant of an older inner slope when the crater floor was at a higher level. Except for the gentle slope from the rim to this residual bench, the crater rim was very sharp. The inner slope of the crater, made up of loose or only slightly consolidated lapilli, with very few bombs, sloped directly to a small basin appearing to be no more than 2 or 3 meters in diameter (pl. 40A). At times this basin showed incandescent lava and even 
produced a few weak gas bubbles that spattered some lava a few feet into the air. Usually, however, the basin floor was covered with ash that slid down from the nearby slopes. Occasionally this vent showed some mild and sporadic activity, during which a brownish dust arose in a thin, weak, and tenuous column. Somewhat higher than this lower vent was a circularly depressed area in the side wall of the crater. This saucer-shaped depression was about 8 meters in diameter and bounded by an almost continuous circular crack. In the bottom of this saucer were two small irregular vents, and around them was a halolike zone of thin sublimate products. Steam issued from these two vents almost continuously with a tremendous grating roar. For much of the time, the vapors issuing from the vents were invisible, their presence attested only by the deep roar from the orifices and the condensation of the vapors into irregular rising clouds above the crater rim. At other times, however, the vapors rushed out of the vents as visible jets of steam, as if escaping from a nozzle at high velocities. No distinct odor was apparent on the crater rim. Except for the emission of vapors, which condensed in tatters of clouds above the crater rim, there was little else given off by the crater vents, and the crater activity can be said to have been in a greatly reduced state.

During this rather erratic and reduced state of activity, there appeared little movement of lava in the flows. Issuing from a secondary vent in the Taquí lava front, a subsidiary tongue of torn and twisted lava was advancing slowly over a portion of the lands of La Lagunita. Activity at the hornitos, however, indicated that the lava still flowed beneath the congealed crust at Mesa de Los Hornitos.

\section{HORNITOS AND VOLCANCITOS}

Late in the afternoon of May 24, several interesting events took place which throw some light on the formation of hornitos and volcancitos. At the "cave"-a collapsed volcancito that was a prominent feature of Mesa de Los Hornitos for the last few months-a small lava flow suddenly broke out, issuing from a small area of jumbled rock, locus of the original volcancito vent. This pasty lava flowed slowly from the vent, and the throat soon became a bubbling mass of viscous lava from which doughy bombs were thrown out to the height of a few feet. These masses congealed to irregular shining black masses. Two narrow open fissures in the congealed crust of the lava of Mesa de Los Hornitos connected the cave with a large asperous hornito that occupied the former site of the lava window. These crevasses were lined with a thin film of sublimates, fine spangles of hematite, and a chocolate-colored dust. From a point on the larger fissure, there suddenly issued a rush of gas with a loud hissing and a small column of fine brown dust, followed by a very vesicular froth 
of viscous lava that grew within a space of a quarter of an hour into an hornito about a meter high. The rapid rush of gases from the orifices blew small irregular fragments from the vents and even loosened larger slaggy masses from the growing hornito. In this manner a hornito originates and grows-a froth of gas-laden lava spewing from a crevice upon the crust of the flow. We were unable, unfortunately, to continue our observations on this hornito during its complete life.

At the same time, a large conical volcancito, lying between the cave and the base of the cone, began to pour out a thin viscous tongue of lava from its summit orifice which, flowing down the steep side of the cone to its base, congealed as a small rough flow, demonstrating the manner in which a volcancito grows in size.

\section{Parangaricutiro LAVA TONGUE}

From its outbreak on January 8 along the south and east base of the cone until early April, the Taqui lava flow had advanced to the east base of Cerro de Equijuata, filling the valley of Tipacuaro from Cerro de Equijuata on the west to Lomas de Capánguito on the east. Its advance had now practically ceased, only a few weak lobes moving slowly and erratically forward. By April 24, however, lava burst out of the summit of the Taqui flow and covered the lands of Turimbiro near the east base of Cerro de Equijuata and reached the San Juan Parangaricutiro-Uruapan road, advancing in two tongues and threatening the waterline to the town. Its front was now but 0.6 kilometer from the outskirts of the town. A lava stream about 10 meters wide flowed quietly from its vent at a rate of about 180 meters an hour.

The east approach to San Juan Parangaricutiro was through the short narrow valley of Juanantacua, connecting the arable fields of Rancho Tipacuaro with the town. To the south of this valley rose the steep wooded slopes of Cerro de Capatzun; and to the north, the slopes of the mesalike fields and woods of Nicorroso that lie between San Juan Parangaricutiro and Angahuan. Through this narrow valley passed the road from Uruapan to San Juan Parangaricutiro. During the month of May, the lava flows which broke out of the lava front at Turimbiro and were actively advancing in April completely filled this small valley and came to rest in the cemetery at the edge of the town. The main lava front extending across the valley for a distance of 150 meters was about 10 meters high and had the usual appearance of a mass of block lava, rubble, and clinkers. At this time we were not impressed with any essential difference between this flow front and others we had witnessed, but photographs suggest that this form was more clinkery and less blocky than previous flows. A 
narrow tongue of torn and twisted lava had advanced several hundred meters down the narrow but steep-walled Arroyo Principal, which passed the eastern edge of town. Such torn and twisted lava, although observed previously as short ephemeral lobes in the earlier flows, was, as we shall later see, the characteristic lava of the late stage of the Taqui flow.

After a period of repose the lava front, at the edge of the town of San Juan Parangaricutiro, again resumed its advance and on June 17 began to invade the town itself (pl. $40 B$ ). The flow followed Arroyo Principal at the eastern edge of the town but, spreading laterally when the arroyo was filled, soon reached the first street. The new advance of lava showed distinct differences both in character of movement and in structure from previous flows. The advance of the lava down Arroyo Principal was rather rapid; the lateral spread was at a rate of 1 to 2 meters per hour. But instead of advancing as a moving front of rubble, the lava moved as distinct and independent lobes. At intervals along and usually halfway up the lava face, viscous lava broke out in tongues. The movement of the lobes persisted for less than a day, when they congealed; and the intervening sectors put out other lobes. These lobes sometimes issued from distinct orifices, yielding rough tongues suggesting tooth paste squeezed from a tube.

At the same time, the main body of lava continued its advance, yielding not so much the clinkery blocky surface of the earlier flows but huge torn and slaggy masses (pl. 44B). Torn and striated blocks rose above the general level of the lava, frequently showing a grooved, or harsh surface. The creaking of the moving blocks was frequently heard. The lower portion of the Taquí flow, beginning at the cemetery and extending to its ultimate advance at Huirambosta, we have called the Parangaricutiro tongue.

The advancing tongue, as it flowed down the steep and narrow Arroyo Principal, frequently showed remarkable fluidity. At a point about a kilometer below the town, the flow advanced down the arroyo as a steep front at a rate of about $\mathbf{4 0}$ meters per hour. Almost the entire front, confined by the steep high walls of the arroyo, was incandescent and flowed like soft tar in bulging lobes. This rapid and incandescent advance compared in rate of movement and apparent liquidity to other lava flows near their source. If one considers that this lava had presumably left the Taqui vent 6 months before and had already traveled 8 kilometers, with several pauses, the retention of its heat and power to advance seems remarkable. A few days later a number of distinct lava streams broke forth from the summit of the lava flow near its farthest advance and, moving rapidly down the flanks in radial incandescent streams, spread out 
into a fan-shaped mass (pl. $44 A$ ), covering 350,000 square meters of terrain in a single night.

During this period (June and July) the rainy season was already well advanced, and the high humidity of the atmosphere was conducive to the condensation of vapors emitted by the lava, so that these vapors frequently became distinctly visible, particularly over the lava at the cemetery where it had accumulated in considerable thickness in the narrow stretch between Cerro de Capatzun and Cerro de Calvario. Banks or clouds of vapor formed several hundred meters above the lava flow, with moving pendulous stringers, or "tails," of vapor hanging below them and indicating that the lava, although now more than 6 kilometers from its vent, still contained and emitted considerable vapors.

Eruptive activity in the crater during the summer was considerably reduced and more erratic than previously (pl. 42A). Frequently the pure-white eruptive column contained only ashless vapors that rose languidly, sometimes to a great height. At other times invisible vapors issued from the crater and condensed as white cumulus clouds above the volcano. It was often difficult to distinguish these eruptive vapors from the normal clouds brought on by the rainy season. At. other times the column consisted of a tenuous brownish dust without visible vapors.

\section{DESTRUCTION OF SAN JUAN PARANGARICUTIRO}

The steady and inexorable advance of the lava finally convinced the remaining inhabitants of San Juan Parangaricutiro that they must evacuate their town (pl. 41A). Previously many people, mostly Mexicans, took advantage of their government's offer to resettle on new lands near Ario de Rosales in Michoacán. The remaining population, chiefly Tarascan, elected to remain, hoping that some miracle would occur to save their homes. Now, as the lava covered plot after plot and destroyed each street in succession, they made feverish efforts to salvage their possessions and the lumber of their houses. The sacred Señor de Los Milagros was moved in solemn procession to Uruapan, and the interior of the church was dismantled. Because of their deep attachment to the soil, many remained until the lava covered the last small corner of their land, then sadly departed by the trucks their government had placed at their disposal. With the destruction of the church the strongest tie that bound them to the place was broken. By mid-July all but a few outlying squares at the western edge of the town were covered by lava. Of the church only the 75-foot towers projected above the torn lava surface (pl. $43 A$ ), and the apse with its altar nestled within a basin of jumbled lava blocks. Curiously enough, 
a small kipuka ${ }^{24}$ within the middle of the flow lay uncovered a short distance to the northeast of the church.

The following described July days may be considered as typical of the events during this period:

July 6, 1944.-As we entered San Juan Parangaricutiro at about 7 p. m., the cone showed two well-defined and separate eruptive columns: one from the central portion of the crater rather weak and very pale gray; and one from the south vent, more voluminous and grayerboth rose rather languidly without cauliflowers. No noise was audible in San Juan Parangaricutiro, and there were no incandescent ejecta until about midnight when bursts of glowing ash appeared intermittently in a column of increased size and a few bombs fell on the west slope of the cone.

We found that the lava had spread considerably toward the west, across the northern part of the town and less toward the southwest in the direction of the church, from which it was now only 25 meters distant. As before, the lava advanced as spreading tongues, or lobes, moving toward the west at a rate of about 2 meters per hour and toward the south about 1 meter per hour. The north and fastermoving lava front was lower ( 3 meters high) than the south slower front (5-8 meters high).

During the night the eruptive column rose majestically to a height of $1 \frac{1}{2}$ kilometers and was then carried abruptly toward the southwest by the upper air currents.

July 7, 1944.-During the morning, a weak column of gritty somewhat brownish ash rose without great force or cauliflowers or perceptible vapors. Sometimes two types of eruptive columns could be distinguished simultaneously, weak and pale from the central orifice and larger, denser, and darker from the south vent, both columns erratically increasing or decreasing.

We talked with a man from Los Reyes about 30 kilometers west of the volcano who reported that the heavy rains were carrying great quantities of ash down the streams, burying fields and filling irrigation ditches, and that last year the ash did great damage to the sugar cane.

The lava continued its normal advance. The people of the town busily removed the last of the houses and dismantled the interior of the church. The men removed the heavy beams, while the women and children carried away the cupboard doors and the flower stands. On this day they removed the pulpit, confessional booths, and the carved stone baptismal font. The padre believed that the church would have remained secure, had they not removed the sacred image of the Senor de Los Milagros. Only a few old people remained, and

24 An uncovered open space, surrounded by lava (Stearns and MacDonald, 1942).

338669 O $-55-8$ 
they feversihly dismantled their houses by day and disconsolately watched the advance of the lava by night-there remained but one street free of lava in the town.

We made a tour of the lava front in the late afternoon and evening. The west, or lateral, lobe had decreased its rate of advance; and behind the church it no longer showed apparent motion, having stopped 20 meters from the apse; but a new tongue was advancing from the northeast toward the parish wing. The flow down Arroyo Principal showed renewed activity after a period of almost complete quiescence; tongues of viscous lava broke out laterally at many points. At Hidalgo Street three caves with domed roofs had formed in the lava, presumbably by the arching of the surface crusts. The main flow had increased in height to about 15 meters above the ground level, making its total thickness from the arroyo bottom about 20 meters. Some lateral tongues broke out near the crest of the main flow and flowed viscously down the lava front. We watched a fine lateral tongue issue from a cavelike orifice near the crest of the main stream, flowing like soft tar down the torn and jumbled lava face and finally spreading fanwise at the base of the flow. Near the terminus of the main lava tongue a number of flows broke out from the top of the lava and moved in radial streams from their source (pl. 44A). The main lava flow at this time was $1 \frac{1}{3}$ kilometers beyond the outskirts of the town.

Little incandescent ejecta came from the crater at night, and a few bombs fell on the south slope of the cone.

Very heavy rain in midafternoon obscured the cone, and after the rain much water vapor arose from the Parícutin flow of June 1943.

July 8, 1944.- The lava tongue behind the church showed no apparent movement, but the new lobe advancing from the northeast approached slowly and was only 20 meters from the parish wing of the church.

We went to Zirosto village, 8 kilometers west of San Juan Parangaricutiro, following the length of the flow. The lava tongue had now reached the Llano de Huirambosta, almost 2 kilometers beyond San Juan Parangaricutiro. The activity of the lateral tongues, so strikingly active last night, had now diminished or completely ceased. The summit flows of last night had spread fanwise over the fields to cover a large area of land but were now completely motionless.

The forest along the Zirosto road was badly damaged, with broken limbs and many dead trees. The fields of Zirosto were covered with a heavy mantle of ash, for the heaviest falls of last year drifted largely in this direction. About one-half of the inhabitants had deserted the town. One of the inhabitants reported the depth of the ash to be about a meter. Attempts to raise corn in the ash failed; for although the seeds sprouted, the shoots soon withered and died. 
Action from the crater remained erratic and apparently continued from two vents, with billowing cauliflowers from the central orifice, and a gritty column from the south vent. Frequently the white vaporous eruptive column was completely lost, commingling with the clouds drifting in from the west.

There was very heavy rain during early afternoon. Some of the waters of Arroyo de Nureto (near Angahuan) were collected and the volume of volcanic ash was found to be more than half.

By early August the lava tongue of San Juan Parangaricutiro had entirely ceased its movement, its ultimate advance reaching Llano de Huirambosta, where the arroyos of Parícutin and San Juan Parangaricutiro joined. The Taquí flow, following its mean course, had a length of 10 kilometers with a maximum spread, over the lands of Quitzocho, La Lagunita, and Huaririo, of 23/2 kilometers.

\section{LATER stage of TAQUí FLow}

The Taqui vent continued to yield abundant lava, which sometime during late July or early August, instead of finding its way by subsurface flow to the lava tongue of Parangaricutiro, advanced as a sheet from an undetermined point overriding the previous flows around the base of the cone. This secondary vent fed a front of lava that spread from the cone across the valley to Curinguaro, advancing as an irregular wall toward the north. A narrow tongue turned westward and passed the base of Sapichu and flowed between the old ashcovered Quitzocho flow and the flanks of Cerro de Jarátiro, its ultimate narrow and torn tip forming a sliver of lava between the Quitzocho ridge and Cerro de Jarátiro. This tongue of the Taquí flow we have called the Campamento tongue. By August 15 the Campamento tongue had built a wall of rubble rising above the level of the second Cerro de Jarátiro crater; and a thin stream of lava, flowing between low-bounding levees of rubble, reached the bottom of the old crater where it formed a low fanlike delta. On the 17 th, liquid lava broke out of the front above the old Cerro de Jarátiro crater rim along a front of about 30 meters and poured into this ancient crater. Within 6 hours the flow filled the old crater almost to its lower eastern lip. The effect of this outbreak was to drain fluid lava from the main body of the Campamento tongue and to form a grabenlike depression traversed by rubbly parallel ridges extending toward Sapichu. Soon after, new incandescent tongues issued from secondary vents in the neighborhood of Sapichu, which appeared, in the obscurity of the night, to come from points near the head of the subsided or grabenlike area.

It is unnecessary to report here all the vagarious movements of the lava tongues of the flow during this period. It will perhaps suffice to 
say that at a number of points along the slowly advancing lava front fluid lava broke out of its enveloping mantle of rubble and clinkers to send out lobes and tongues, and even flows of considerable extent (Bullard, 1947). These subsidiary flows now occurred frequently. In the previous flows these tongues were not common and were then usually only short lobelike protrusions. Their more frequent occurrence may be ascribed to the flatter terrain over which the main flows passed and their resultant slower advance, with consequently greater accumulation of fluid lava in the main body of the flow. The pressure of this "intruded" lava must then find some release through the rupture of the enveloping shell.

On September 27 (Bullard, 1947), lava from the Taqui vents, after having flowed for more than 8 months around the south and east sides of the base of the cone, began flowing toward the north, following Arroyo de Parícutin and filling the valley between the first Paricutin flow and Cerro de Canicjuata (pl. 50). This new flow issued from a "graben" in Mesa de Los Hornitos. Upon reaching the flatter terrain about Parícutin, it spread laterally and covered the site of that unfortunate ash-buried village. Continuing along Arroyo de Parícutin, it invaded Llano de Huirambosta and on October 20 finally joined the Parangaricutiro tongue near the end of its course. This later Paricutin flow showed the normal characteristics of Parícutin's lava, a high steep front, mantled with broken blocks and clinkers, and partial discoloration by gaseous emanations. The contact of these two lava flows formed an interesting contrast of lava types. A few weak fumaroles developed in the lower part of the flow but did not persist.

\section{THE CRATER ON NOVEMBER 26, 1944}

A second ascent to the crater was made on the morning of November 26. The general configuration of the crater was somewhat changed from that as we saw it on May 25. The rim of the crater was now rounded and not sharp as on the previous ascent, and one could walk along the broad crater edge with ease. The highest point on the crater rim was the eastern edge, where the aneroid read 2,740 meters. The western edge was somewhat lower, 2,710 meters and the north lip 2,690 meters. The south lip was the lowest, but a regular shower of bombs in this direction precluded a complete circuit of the cone. The inner north slope of the crater was occupied by a bomb-littered bench, the remnant of a previously higher floor. The inner edge of this bench, which rose slightly from a low trough, had an altitude of 2,675 meters. From the rim of the crater and the bench, the sides sloped down to two orifices, a central and a south vent. 
The central vent was a deep, narrow funnel and showed but little activity. Small clouds of white vapors rose lazily from the orifice, occasionally increasing in volume until they filled the bottom of the crater.

The south vent was a saucer-shaped depression in the bottom of which were 5 or 6 main orifices, with perhaps some smaller ones. This vent showed violent but erratic steam activity; jets of vapor rushed from the orifices with great velocity, abrading the adjoining crater wall. The individual jets of vapor coalesced somewhat below the crater rim into a medium-sized light-colored eruptive column. Activity in the individual orifices was not steady but irregular and erratic. The largest orifice was an irregular opening, perhaps 4 meters across, which blew off at frequent intervals tearing incandescent lava from its throat and carrying bombs well above the crater rim. Orifice number 2 was small, less than a meter across, and almost continually blew off white steam. This orifice had a cone mouth, like a miniature volcano, about three-fourths of a meter high. Orifice number 3 , not clearly visible, gave off copious white vapors directed toward the southwest. Orifice number 4 appeared to be a double vent that blew off at intervals of $1 / 2$ to 3 minutes toward the west and carried some ash. Other vents could not be clearly distinguished in the vaporous confusion in the crater pit.

The vapor column carried with it bombs torn from the throat of the vents. One could sometimes observe a large bomb torn from the orifice. The vents also discharged finer material. In addition, the eruptive column scoured ash from the nearby wall. Occasionally material slumped from the crater walls into the vent and was blown out in ashy volutes by the rushing vapors.

The noise of the vents, particularly from orifice number 1 , as heard from the crater rim, was almost deafening. Numerous shocks swayed the upper part of the cone, particularly near the lower south rim, where the tremors were so strong and frequent as to induce in one a feeling of dizziness. Frequently the activity in the orifices of the south vent increased after a heavy tremor, but no regular relationship was observed.

\section{RAIN EROSION}

During the rainy season of this year, June-September 1944, storms seemed to be more frequent and violent than during the preceding rainy season (pl. $41 B$ ). The ash mantle of the area surrounding the volcano showed much more erosion than previously. The steep hill slopes, like those of Cerro de Jarátiro and Cerro de Canicjuata, were deeply rilled and gullied (pl. $47 \mathrm{~A}$ ), extending down even to the original soil cover. The abrading action of the ash-laden waters and the dis- 
appearance of grass or herbaceous cover allowed the rapid scouring of the original soil so that denudation of the hill slopes took place at an accelerated rate. It was early noticed, however, that the ash beneath the pine trees was more resistant to removal, owing to the accumulated mat of pine needles, which served the same function as pine needles or straw in adobe. On other slopes, like that of Cerro de Canicjuata, a downhill tilt of the dead pine trees indicated a downhill creep of the ash blanket.

A single storm might excavate a deep steep-walled arroyo in the heavy ash cover. Such an arroyo, 7 meters deep, formed along the base of Cerro de Canicjuata (pl. 47B). The material excavated was spread at the mouth of the arroyo as a low alluvial fan extending over much of the area formerly occupied by the village of Parícutin. Boulders weighing 20 kilograms or more, found intermingled with sticks and grass in the crotches of trees, attest to the transporting power of these heavily ash-charged streamflows.

\section{AHUÁN FLOW}

Sometime in mid-November, exact date not known, lava broke out at the south base of the cone, below the south vent in the crater (pl. 45B). Accompanying this flow was a slump in the south slope of the cone, forming a triangular segment, reaching about one-half the way up the slope of the cone. At the eastern end of this break the crater slope showed a steep, half-funnellike slide at the base of which issued the lava stream. As near as can be judged, this point coincided with the vent (fig. 123) of the September 1943 flow and occupied a position on a line through the main crater and the Sapichu vents. A small lava dike was exposed in the wall of the cone a short distance above the lava vent. This dike, 50 centimeters wide, had a strike of N. $10^{\circ} \mathrm{W}$. (magnetic) and a dip of $65^{\circ} \mathrm{E}$. On the opposite side of the lava stream, or to the east, was a small pyramidal hill of fume-oxidized ash evidently a section of the main triangular slump, which was broken off, twisted, and carried about 100 meters by the outbreak of the lava. At the south base of this small hill stood a contorted slab of lava, a part of the dike exposed in the cone's wall. This slab had a remarkable resemblance to a seated rabbit, and for this reason we named the vent Ahuán [auani (Tarascan)=rabbit]. The lava issued quietly from the base of the funnel-shaped slope, passed under a low lava bridge where congealed crust had already begun to form, flowed with a faint tinkling, and emitted choking bluish fumes. The flow showed a bright-orange incandescence dappled with abundant dark scoriaceous clinkers.

On December 2 we were able to cross the rough clinkery surface to the edge of the moving lava stream. By this time the apparent vent 


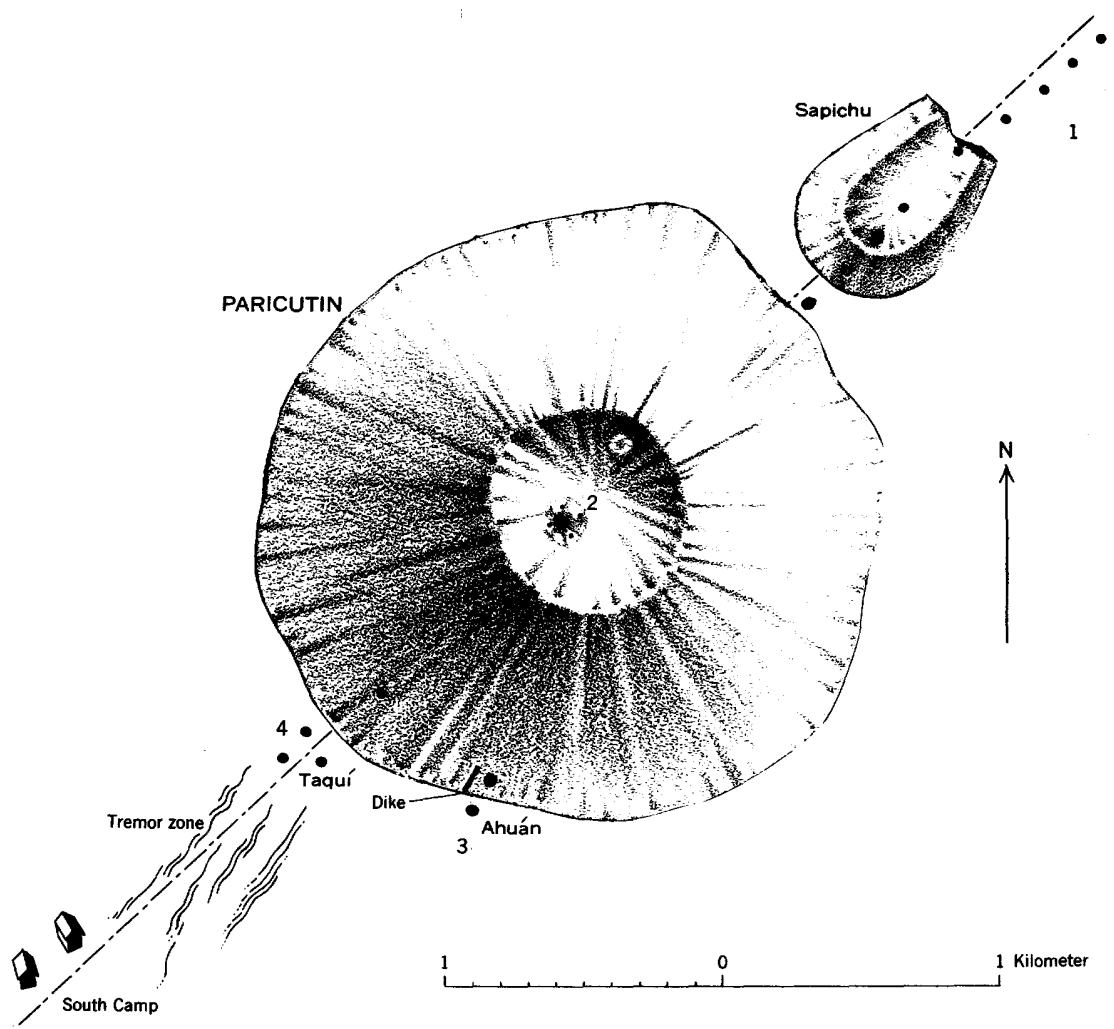

Figure 123.-Paricutin volcano, showing the vents of 1943-44.

1. The Sapichu vents of October 19, 1943.

2. The Cuiyúsuru or main crater vent.

3. The Ahuán vents.

4. The Taquí vents.

had moved downstream about 10 meters owing to the congelation of the surface over the upper part of the flow. At the head of the flow was a low horseshoe-shaped levee about 2 meters across. Between this levee and the moving lava were several incandescent crevasses from which hissing invisible vapors issued. Lava issued quitely from the narrow vent. About 50 meters below the vent the stream was 6 meters wide. It showed an orange incandescence dappled black by congealed lava and did not break up into clinkers in the upper part of the flow. The flow moved quietly with an occasional heaving of the surface. On rare occasions these heaving spots swelled to large blisters, some of which burst with a hiss and scattered incandescent masses of viscous lava. This flow we have called the Ahuán flow.

Roughly paralleling the lava stream were irregular low ridges of clinkers, apparently old levees formed on preceding days when the lava had flowed by a somewhat different course. Levees also formed 
along the lower stretches of the flow (p. 46B). About 5 meters from the stream's edge were irregular vents of escaping gases or incipient fumaroles, surrounded by a tenuous deposit of yellowish sublimates By the next day (December 3) the head of the flow had frozen over for a distance of about 75 meters, and the surface was covered with a pinnacly crust, stained with yellow and orange salts.

On the crusted head of the flow between the apparent lava vent and the base of the cone, a hornito, about $1 \frac{1}{2}$ meters through the base and $1 \frac{1}{2}$ meters high, had formed. It contained many incandescent orifices, particularly on its summit. These vents carried delicate growths of hematite and magnetite crystals. Gases issued from these vents with a continuous hissing. The maximum temperature measured in the incandescent orifices of this hornito was $1080^{\circ} \mathrm{C}$ (Ziess, 1946). Measurements in the crevasses surrounding the head of the lava flow were $1020^{\circ} \mathrm{C}$.

By December 2 the Ahuán flow had encircled the south and east sides of the base of the cone and moved over the older ash-covered Sapichu and the Taqui flows (p.l 46A), the lava front extending from Sapichu southeastward across the older lava fields. The lava front reached a height of 15 meters; and from this front of rubble, tongues of rough lava extended at intervals in advance of the main flow. The subsidiary tongues sometimes reached a length of 300 meters. The whole front advanced slowly and erratically except at its northwest corner near Sapichu, where the lava front was broken by subsidiary lava tongues. One such tongue began on December 5 ; moved into the basin formed by the Campamento tongue of the Taqui flow, the Quitzocho ridge, and the base of the cone; and soon filled the whole basin. On December 6 lava continued to flow into this basin, moving over portions of the deeply covered Quitzocho and Sapichu flows; but since the containing slopes of the cone, the Quitzocho ridge, and the south flank of the Campamento tongue allowed little lateral expansion, the increment of the new lava raised the general level of this new tongue, creakingly lifting the already congealed surface and causing fissuring in the enclosing shell of solidified lava. At the same time, the augmented volume of new lava increased its pressure on the containing wall of the apparently congealed and partly ash-covered Campamento tongue to the extent that cracks also began to appear on the surface of this lava.

On December 7 the volume of the new lava moving into the basin continued to increase, and the fissuring in the old Campamento tongue became more evident. In the morning a small tongue of incandescent lava broke out of the Campamento flow, indicating a drainage of lava from beneath an enveloping crust. By afternoon the whole western portion of the old Campamento tongue was slowly rising, and its 
north face, opposite the pushing mass of the new lava, rose and steepened until it was about 10 meters high. This readjustment took place with the slow continuous fracturing of the solidified lava, and the irregular front with flow crevasses changed to a steep wall of broken angular blocks. From all directions on the flow the continuous noise of fracturing and movement could be heard. Liquid lava began to seep through the broken front. These lava seepages frequently began as an incandescent spot in the brecciated lava wall and ended when viscous lava bulged from between the rocks and flowed as a slowly moving lobe, carrying with it freshly broken blocks of the lava shell. One flow came from a newly formed narrow gash in the old lava, about 1 meter wide and 4 meters deep. This cut gradually widened until its walls were 3 meters apart. Meanwhile the viscous lava, moving down this gash, spread as a fan at the foot of the Campamento flow, but after a few hours of activity it ceased to flow.

Late in the evening a strong steady glow over the western portion of the old and apparently congealed Campamento tongue suggested the reappearance of incandescent lava. A wide and deep gash had developed and cut diagonally across the lava, almost to the pushing Ahuán lava, a distance of about 150 or 200 meters. Apparently this new channel had opened very recently, for lava had only now begun to pour from the mouth of the gash. No unusual disturbance was noted to indicate that the splitting of the Campamento tongue was other than gentle and gradual. A stream of viscous incandescent lava about 10 meters wide poured from this channel at a rate of about 10 meters per minute and began to spread out as a flat lava cake in the small basin lying between the Quitzocho ridge and Cerro de Jarátiro. This small flow spread like many of the smaller rapidly moving lobes, first by bulging forward in incandescent orange lobes, then platy slabs of congealed lava formed at the surface of the flowing lobes. As the front advanced, the congealed lava from the top slowly rotated toward the front, like the advancing treads of a caterpillar tractor, then rolled under at the foot of the flow. At a later stage loose clinker blocks formed on the surface of the flow, and eventually the whole front was a mass of advancing rubble. This small flow showed little fumes and had no decided odor.

This curious action of the apparently congealed Campamento tongue suggests that the flow contained a still fluid core, surrounded by a shell of congealed lava, and that the pressure exerted upon this body of still molten material by the push of the Ahuán lava caused the rupture of the shell and the escape of the contained molten material.

In the meanwhile new tongues of lava, breaking out from the Ahuán lava front near Sapichu, moved rapidly but erratically northward and on December 8 reached the camp and threatened to destroy the 
cabins. These cabins, built along the edge of one of the old craters, were about 50 meters above Quitzocho, or the fields at the foot of Cerro de Jarátiro. The great change in the topographic appearance of the vicinity can well be imagined, for it was no longer necessary to descend a high hill to reach the lava level; a glance from the cabin window revealed a high and rubbly lava front overlooking the cabin itself. A long rapidly advancing tongue moved past the doorway and spilled into the remaining uncovered portion of the parcel of La Lagunita and spreading rapidly the next day poured into the deepest and last remaining old crater of Cerro de Jarátiro.

The cabin was hurriedly dismantled and moved to the highest point of Cerro de Jarátiro, about 100 meters above Quitzocho; it seemingly was inconceivable that the lava would ever reach this elevation on the summit of a high ridge, but the cabin was again moved in December 1946 to escape a higher lava flow.

With the outbreak of the Ahuán vent, activity at Mesa de Los Hornitos greatly subsided, owing probably to a diminution, if not entire cessation, of lava from the now deeply buried Taquí vent. Mesa de Los Hornitos was greatly disturbed and traversed by deep crevasses. An ash mantle covered the lava and smoothed the asperities of its surface. The volcancitos were so modified that they were no longer recognizable, while the hornitos were mere hummocks of ash, from the summits of which protruded slaggy lava, frequently tinted by sublimates of alteration products.

Some of the crevasses in the lava crust were the reopenings of older cracks and frequently showed bright alteration colors, owing to the passage of gases through these older crevices. Some of the crevasses, too, reopened old cracks along which the froth of the hornitos had passed and exposed their channelways to view. The features of the hornitos thus exposed confirmed the previous observation that they are a froth of gas-charged lava that arose along cracks in the congealed crust of the flow. Dissection of some recently extinct hornitos showed them to have a spongy open structure. Sometimes small quantities of steam still issued from these dissected hornitos, and there was frequently detectable a sharp odor suggesting hydrochloric and sulfurous acids. The condensed steam wet the surface of the cracks and cavities and had a biting acid taste. The cavity walls of the hornitos showed considerable rock alteration. Flesh-pink to minium-red or pale-gray coatings colored the surfaces, and there were frequently nests of needlelike sulfur crystals, golden-yellow stalactites of chloraluminite, small pearly lathes of gypsum, and other less well defined products.

During the period of early Ahuán activity, the crater showed a more than usual heavy eruptive column, although only lightly charged with ash. The activity, however, was extremely variable, changing from 
periods of no visible vaporous emissions to heavy wooly cauliflowers with frequent lightning. From the configuration of the crater as seen on November 26 and the level of the lava vent of the Ahuán flow, it was quite evident that the throat of the crater vent and the origin of the eruptive column were not more than a few meters above the top of the rising lava column in the lava conduit.

A description of a few days in December will give an adequate idea of the character of the eruptive activity from the crater during this period of Ahuan activity.

December 3, 1944.-During the early morning hours, from about midnight until $4 \mathrm{a} . \mathrm{m}$., the crater was very quiet, with no visible vapor column and only occasional weak bomb bursts, contrasting strongly with the heavy billowing column of last night. At 4 a. m. increased activity took place until 6 a. m., dying suddenly and leaving the cone clear except for a few small lazily rising white vapor clouds. At 9 a. m. eruptive activity began gradually to increase, soon yielding a gray wooly column of rising cauliflowers with strong erratic bomb bursts. At noon a wooly gray column arose rather lazily, accompanied by a low sound like surf. In the afternoon a gray wooly eruptive column slowly ascended with rather numerous bombs.

From 6 to $9 \mathrm{p}$. m. a heavy ash column was thrown up with intermittent bursts of bombs and brilliant lightning flashes, some vertical, some horizontal, and others irregular. From 9 p. m. until midnight the frequency of bomb bursts gradually decreased, but the duration of the bursts increased, in some instances a continuous streaming of bombs lasted for 1 minute. At midnight the activity was again reduced to a lazily rising column.

December 3, 1944. - In the morning there was a heavy eruptive column with frequent strong bursts of bombs and much lightning. The activity continued strong all day until 2 p. m., when the eruptive column suddenly subsided. From $9 \mathrm{p} . \mathrm{m}$. to midnight the eruptive column was a thin white vapor column colored a beautiful rose pink by reflection from the incandescent lava stream below. The column was accompanied by erratic bomb bursts rising to a height of 300 meters.

December 4, 1944.-From midnight until 5 a. m., a dark eruptive column rose without noise that was audible at the camp and with bursts of bombs gradually increasing in number until activity became strong. Activity continued so for most of the day, increasing greatly at $4 \mathrm{p}$. m. and subsiding at $5 \mathrm{p}$. m. to a lazy, somewhat brownish, column (pl. 48).

December 5, 1944. - There was a lazy continuous column all day, with weak bomb bursts. The eruptive column was rather tenuous and pale brown. No noise audible at camp. 
From these few days' description of a characteristic period during the Ahuán episode, it is evident that eruptive activity was erratic and unpredictable; periods of quiet, alternating with others of a dense wooly eruptive column. During these alternating and vagarious phases of eruption, the lava stream continued surging from its vent without apparent change. The only observed correlation between crater eruption and lava flow activity, if it were indeed not entirely fortuitous, was an increase in the escape of gases from the crevices at the head of the Ahuan flow. The escape was accompanied by ejection of some small incandescent bombs from these crevices, during a rapid slackening of eruptive force from the crater, observed on the afternoon of December 4. The calm and continuous flow of lava from the vent unaffected by the wide and sometimes sudden changes in the crater's activity was frequently and widely commented upon.

In the course of the next few months the apparent source of the Ahuán flow moved progressively downstream, owing to the accumulation of congealed lava over the upper reaches of the flow. This frozen roof became a jumble of blocks and scattered low hornitos, brilliantly colored with efflorescences of yellow, orange, and buff sublimates. By mid-January 1945 the flowing lava issued from a low-domed tunnel, about 150 meters from its original source. Here the open orifice was about 3 meters wide, and the lava moved at a rate of about 45 meters per hour. This small secondary vent fed a large lava front moving along the south and east sides of the base of the cone, passing Sapichu and spreading out over the surface of the older flows. The main flow then divided into two irregular tongues: one, now rather sluggish in movement, flowed toward the west as far as Quitzocho ridge and the camp; a second, actively advancing as a sinuous irregular tongue, moved toward Cerro de Pantzingo, near the northeast edge of the lava field.

Sometime in May the Ahuán flow changed its apparent vent from the low tunnel mentioned above to a lone volcancito on the Ahuán lava flow. This vent, presumably, was not a true lava conduit, but a point in the congealed crust where the lava found exit. This steep conical volcancito was about 10 meters high and situated about 100 meters southwest of the original Ahuan vent, the point where the flow first broke out from the base of the cone. The locus of the volcancito falls very nearly upon the axis of the Sapichu-main crater vents, a situation which may be entirely fortuitous. It is possible that the locus of the volcancito was determined by nothing more than a vagarious opening in the lava crust which allowed the escape of gases and lava from the lava stream flowing below. The volcancito was originally steeply conical in form, but its southwest flank soon collapsed, exposing a number of incandescent vents from which vapor 
escaped with a loud hissing. On its summit a chimneylike throat about 3 meters in diameter lazily issued bluish fumes. A low lava scarp passed the foot of the volcancito, extending both northwest and southeast of the volcancito itself and suggesting that the collapse of its flank was the result of a subsidence of the lava crust. To the northwest of the volcancito was an area of "cordwood" lava, grading toward the south into pahoehoe lava. To the southeast for a distance of about 300 meters, the low lava scarp showed numerous incandescent crevices hissing out bluish fumes.

The actual lava stream now issued from a crevassed and sublimatestained low lava ridge about 100 meters east of the volcancito. At the point where it issued from beneath the crust, the stream was no more than a meter wide; and its rate of flow was 4 meters per minute. The lava stream widened rapidly, and the rate of flow decreased. No appreciable impression was made by a large rock thrown upon the surface of the extremely viscous lava that issued from the vent. Like similar flows from Parícutin, its incandescent surface was dappled by black rugose excrescences of vesicular lava, which were portions of the incipient crust torn apart by the flowing lava upon which they rode. Bluish choking fumes were given off by the flow, and occasionally the lava heaved but did not yield bursting gas bubbles.

The older Taqui flow, now covered in part by the Ahuán flow, was deeply crevassed; and one was frequently able to descend some of these crevasses to a depth of several meters and observe their structure. The Taquí flow was now apparently completely solidified, and in only a few isolated spots in the crevasses was heat perceptible. The individual flows or lava surges were 2-3 meters thick, separated by about one-third of a meter of red scoriaceous lava or baked brick-red ash. The individual flows were vesicular throughout and sometimes showed an indistinct layered structure in the middle portion of the flow.

\section{THE CRATER ON JANUARY 22, 1945}

An ascent was made to the crater rim during late afternoon of January 22. In the morning a thin eruptive column arose, accompanied by a tenuous gritty ash and a roar like a heavy surf; the column became heavier during the afternoon and rose in volutes. The north rim had an altitude, by aneroid, of 2,685 meters. At this time the crater had a single throat, about the locus of the south vent (pl. $49 A$ ). The south inner wall sloped directly to this vent at the angle of repose, but the north wall showed a well-defined bench and the remnants of two others.

The eruptive crater vent itself appeared to be a chimney with a throat about 3 meters in diameter, but it could not be clearly seen because of its position below the old terrace. Violent explosions in 
the vent induced a strong swaying motion to the summit of the cone. The explosion interval was erratic. Explosions averaged about 10 per minute. The eruptive column was blasted violently from the vent, but a few meters above the throat it expanded into its first volute and then rose more languidly. Frequently the eruptive column drifted slowly around the crater with a spiraling motion. When such a drifting column engulfed us on the crater rim, a slight odor of hydrogen sulfide was perceptible; and a frothy, semipumiceous ash fell in irregular fragments up to 10 centimeters in size. Bombs were ejected from the vent; those a meter or so across seldom rose higher than 50 meters. The bombs appeared to be semimolten, as they seemed to change shape in their flight.

The effect after dark was fearsome. The incandescent bombs left the crater throat with great speed to form a fan of fire. The larger, slow-moving bombs could be discerned easily, but the innumerable smaller bombs and lapilli were but streaks of light to the eye.

Both in daylight and after dark, compression waves in the eruptive column frequently followed the explosive bursts. When the noise was a rumbling roar, many thin compression rings followed one another in rapid succession. In spite of the tremendous explosions the noise at the crater rim could not compare to that of November 26 .

THE CRATER ON MAY 27, 1945

On May 27, 1945, the crater was entered by W. F. Foshag, John V. N. Dorr, Carl Fries, Jr., and Celedonio Gutiérrez, and again to the crater rim on that night by Dorr and Fries. During this day a purewhite steam column issued from the north vent of the crater with a loud rushing noise, carrying bombs which fell on the eastern rim and slope of the cone (pl. 49A). At rare intervals the south vent gave off a single burst of dense black ash and many bombs. These heavy bursts from the south vent yielded a majestic eruptive column that frequently filled the entire crater and rose rapidly to a height of about a kilometer.

The two vents, as seen from the crater rim, did not seem to occupy the exact positions observed on previous ascents. The north vent was close to the northeast edge of the crater, the steep interior walls of the crater sloping directly to a chimneylike orifice. The south vent occupied more nearly the center of the crater and was much deeper and separated from the north crater by a septal ridge. The walls sloped regularly from the rim to the bottom of the crater, which showed no open orifice.

The activity of the north crater consisted of an almost continuous jet of steam issuing from the open vent with a harsh grating roar. A few highly vesicular brown bombs, like those yielded by Sapichu, 
were ejected to a height of 150 to 250 meters, rarely to 500 meters, above the throat of the vent. The column was slightly inclined toward the east, consequently the greater number of bombs fell on the east slope of the crater and cone. There were but rare pauses of a few seconds in the emission of vapors, the column almost immediately issuing again. The remarkable feature of this vent was the almost constant emission of white vapors and the almost total absence of ash. A slight sulfurous odor pervaded the crater.

During the 3 hours spent in the crater, the south vent showed no signs of activity, although the bomb-littered terrace and inner slopes of the crater indicated that considerable ejectamenta were thrown out during the single explosive bursts to which it was subjected. In the evening, however, Fries and Dorr observed one of these terrifying explosions from the crater rim. The eruption began with a noise like the explosion of a small charge of powder in loose ground and was immediately followed by a rapidly rising but silent heavy eruptive column, which mushroomed out overhead into a dense black pall, from which showered dark (not incandescent) bombs and ash. Previous to this explosion there was no apparent change in the crater itself to give warning of the impending blast, which occurred almost instantaneously. With this single burst, this vent resumed its inactive state.

In the upper part of the septal ridge separating the two main vents, on the slope of the larger but less active crater, were three incandescent orifices, the largest about $1 \frac{1}{2}$ meters across. From these issued strong jets of vapor. They were undoubtec'ly connected with the north vent, for their activity increased and decreased in consonance with changes in activity with this vent.

Lightning was observed at night in the occasional heavy ash column, but none was seen in the steam column.

\section{LATE STAGE OF TAQUí FLOW}

Some time during late June, lava activity shifted from the Ahuán vent back to the area of the Taqui vent. On July 4 the lava field about Ahuán was almost completely inactive; a broad flow of rough, clinkery lava, following the southwest base of the cone, flowed toward the northwest and still showed some slight movement. The large conical volcancito, which was a conspicuous feature of the Ahuan flow, was reduced to a pinnacled remnant surrounded by asperous lava. Abundant bluish-white fumes issued from vents in the remnant of the volcancito. A line of gas vents and sublimate-incrusted cracks marked the last channel of the lava.

Lava now issued from a crevass in a low dome near the locus of the old Taqui vents. This dome of lava had a precipitous southeast 
front, suggesting a scarp, perhaps owing to elevation of the crust by the injection of lava beneath. A crevass almost bisected this low lava dome. Lava issued quietly from the lower part of this crevass as a stream about a meter wide that widened rapidly down its course and split into three tongues. One could approach to within 3 meters of the apparent vent and observe the movement of the lava. It did not appear to well up from any perceptible vent but flowed from its point of origin without disturbance. As the lava moved, the surface pulled apart like viscous tar to form an asperous surface. Lower down the course of the flow, the surface was pulled into loose congealed clinkers that rode along the surface of the flow.

Above the apparent lava vent, the dome showed incandescent crevasses from which choking bluish-white fumes hissed; the vents and the crevasses were colored gray or buff by deposited sublimates.

To the north east of this active lava flow was a high irregular cone of lava, an inactive volcancito.

On July 31, our last visit to Mesa de Los Hornitos, the lava dome from which the flow issued remained relatively unchanged, although the lava now issued not only from the crevasse, as previously, but had also broken out on the opposite side of the dome and from the foot of the scarp of the dome. A short flow was moving from the original vent and another from the vent at the base of the scarp, but the principal flow issued from the dome opposite the original vent and formed a long lava stream that extended to the north for more than a mile. The Ahuán area showed no apparent activity, but the area was colored with a large patch of yellowish sublimates.

In early July the crater showed greater than normal activity and appeared to have three vents. The north vent was in almost continuous activity, and its eruptive column was slightly inclined toward the east. The south vent showed sporadic heavy bursts canted toward the south and sometimes yielded billowing incandescent ash. A west vent exploded at irregular intervals, yielding bursts of bombs slanted westward, showering bombs on Mesa de Los Hornitos. The heavy activity from the crater precluded an ascent to the crater rim.

During this period, sharp pointlike discharges of lightning, accompanied by a sharp shotlike thunder, were not uncommon in the eruptive column.

In late July the crater showed a funnel-shaped form, surrounded on the west, north, and east by a broad terrace (pl. 51). The single eruptive vent probably represented the more persistent south vent. During the brief interval when little ash issued from the crater, it could be seen that the bottom of this vent was occupied by three, or perhaps more, incandescent orifices, from which the vapors escaped with great force. For a brief period two small incandescent orifices, 
emitting small plumes of dirty vapor, appeared on the inner north slope of the crater, below the encircling terrace.

\section{gUMMARY OF THE TAQUí PERIOD}

Although the southwestern flank of the cone showed a minor emission of lava on August 26, 1943, persistent activity did not begin in this area until January 7,1944 , with the outbreak of the Taqui vents. This outbreak immediately followed the complete cessation of activity in the Sapichu vent. The Taqui orifice became the most persistent and long lived of any of Parícutin's lava vents. Emission of lava from the Taquí vents alternated with lesser flows from the Ahuan vent, an orifice corresponding to the earlier Pastoriu and Mesa del Corral flows and which was situated directly opposite the Sapichu vent and presumably upon the same fissure. Because activity from the Taqui vents alternated with that from the Ahuan vent, we proposed to include, for simplicity, the Ahuán activity in the Taquí period.

Taqui's activity began with the surging of lava from three small vents at the southwest base of the cone, which were soon, however, engulfed and covered by their own lava. Numerous flows and tongues of lava issued from these vents, most of which did not appear directly at the locus of the vents themselves but broke out on the surface some distance away after first flowing for variable distances beneath the congealed crust. The largest of these flows, which we have called the Taquí flow, has a total length of about 10 kilometers and covers an area of arable land belonging to San Juan Parangaricutiro and Parícutin and including these two towns themselves. It is difficult to estimate the total ejectamenta and lava during the Taquí period, because the average thickness of the Taquí lavas is not well known. Over Llano de Quitzocho it reached a thickness of about 60 meters. The area covered by the flows of this period, to July 1945, was $173 / 4$ square kilometers. At the end of this period the cone had an elevation of about 340 meters above the original terrain and a diameter at its base of 1 kilometer. The diameter of the crater was about 0.4 kilometer.

The crater showed greater activity during the Taqui period than the preceding Sapichu period but considerably less than during the Quitzocho period. During the Taquí period, explosive activity was erratic, sometimes for very brief periods reaching a violence equal to activity during the Quitzocho period but frequently being reduced to weak emissions, even less than that shown during the Sapichu period. Rarely was the eruptive column heavily charged with ash, and it frequently consisted of apparently pure steam. Bomb and ash types ejected were similar to those of the previous periods. 
During the Taquí period, the cone showed little increase in elevation. Slight increases, owing to an increment of new ejecta, were offset by slides in the crater and by rainwash. These variations induced little change in the appearance of the cone. The crater line showed some notable changes, particularly the north and south crater rims, owing to scouring by the north and south crater vents, sometimes resulting in a marked saddle shape to the crater rim. The only notable changes in the exterior form of the cone were the minor slumps induced by the initiation of the Taquí and Ahuán flows.

The most striking feature of the Taqui period was the growth of volcancitos and hornitos on the surface of the Taqui flow and, to a much lesser extent, on the Ahuán flow. These owed their origin, perhaps, to the fortuitous circumstance that the actual lava vents became buried under their own flows, allowing the molten lava to move through channels beneath a crust, rather than as overriding tongues as in the previous flows. Emanations from the subcrustal lava were then forced to find their escape through vagarious channels in the crust itself. These emissions contained combustible gases, as demonstrated by the striking flames which were frequently observed over both the volcancitos and hornitos. The fountaining of gascharged lava from crustal vents to form volcancitos presented a beautiful spectacle. The short flows that issued from the volcancitos yielded a smooth hummocky pahoehoelike flow or an unusual "cordwood" form of lava.

The lavas of the Taquí and Ahuán vents showed no appreciable differences from those of previous flows, yielding the usual rubble and clinker-covered surface. The only striking difference was in the Parangaricutiro tongue of the Taqui flow, whose torn and jagged appearance is in marked contrast to other lavas. This may be due, perhaps, to its prolonged period of flow. Four and one-half months elapsed from the time the lava issued from the vent until it reached the outskirts of San Juan Parangaricutire and changed its characteristic structure. Perhaps an essential difference between the Parangaricutiro tongue and other tongues and flows was its mode of advance much of which took place, not as overriding tongues but as subcrustal flow. During this time, the lava presumably underwent some crystallization and undoubtedly lost much of its volatile contents. After a pause and apparent quiescence of about 3 months, the Parangaricutiro tongue broke out from beneath its cover of rubble and clinkers at Turímbiro, near the base of Cerro de Equijuata, or about 5 kilometers from its original source.

It was during the Taqui period that there were occasional opportunities to ascend the cone and observe the configuration and activity of the crater. The presence of a persistent and permanent vent near the 
southwest edge of the crater, so frequently apparent in the position of the eruptive column, was confirmed, as was also the lesser but still important northeastern vent. There were also ephemeral vents. The inner configuration of the crater depended largely upon the relative activity of these separate orifices as well as upon the intensity of the activity itself. The actual orifices of the vents were surprisingly small, considering the size of the emitted eruptive column. The character of the eruptive column was also conditioned by the inner configuration of the crater. Where the eruptive orifices were open, a vapor column free of, or only slightly charged with, ash resulted. If the eruptive orifice was choked with ash and debris, frequent ash slides took place into the vent; or where the eruptive column scoured the adjacent wall, the eruptive column was charged with ash. When the eruptive vents were open, the small quantity of ash carried by the eruptive column consisted of brown shredded slag, scoured from the molten lining of the crater vent; and the eruptive column had a pale-brownish and "gritty" appearance. When the vents were choked, the ash consisted of a variety of forms including shredded slag, triturated material, spalls, and other forms, that is to say, such material as made up the cone itself.

During the 18 months that the Taquí period was under observation, it became evident that no further unusual change in the activity of the volcano was likely to take place, that the volcano had settled down to a comparatively regular routine, and that its formative period had drawn to a close. It was no longer an infant volcano but a mature, volcanic apparatus. Activity, although continuous, was considerably reduced in force; and the cone acquired such a degree of stability that it became difficult to change radically its configuration or size. Paricutin was now an established volcano. Its period of youth and development could be considered closed.

\section{GENERAL EFFECTS}

\section{EFFECT ON IIFE}

The effect of the advent of the volcano on life in the region, while not a geological subject, presents some interesting features perhaps worthy of note. The influence of the volcano on human affairs within the immediate volcanic zone can be easily imagined and need not be dealt with here. The destruction of homes and rich farmlands was an overwhelming catastrophe for the folk that inhabited the area.

The effect upon wildlife, although less evident, yielded some interesting observations. The advent of sudden and violent change in a previously placid area brought about a rapid diminution of the animal population of the region. But it appears that fright was not an important factor in this change. Such animals and birds as persisted 
in the region during the early and most violent period of the volcano showed no fear of and even seemed totally oblivious to the terrible events that followed each other in quick succession.

The first animals to disappear from the region were the deer and rabbits, and with them, to a large extent, went the coyotes, owing, no doubt, to the disappearance of their food supplies. As long as the pine and oak trees remained alive, squirrels and jays persisted and left only when the supply of pine cones ond acorns vanished. Smaller birds, like creepers, also persisted, feeding upon the insects still abundant in the forest or blown in by the winds. Eventually these, too, left the area, except for a few occasional stray ones that passed through. The winds brought in numerous bugs of various kinds, which the falling ash battered to the ground. These bugs, consisting of moths and butterflies, grasshoppers and leafhoppers, and other forms, collected in sheltered pockets or in the shallow rills in the ash, and became a constant source of food for such animals as remained. Even after 2 years of activity field mice and foxes persisted, and their tracks could be seen on the ash, even on the ash over recent lava flows. Crows were seen almost daily about the volcano and frequently alighted on the cone, during falls of ash and bombs. It was discovered that the slopes of the cone yielded an abundant supply of bugs, which undoubtedly was the principal attraction for the crows.

Reptilian life was not common. A large lizard apparently found a hole in the warm lava a congenial environment, with abundant food at his door. The few snakes we observed were obviously having a hard time of it, the loose ash not being particularly suited to their manner of locomotion. Frogs died and desiccated in the ashy environment.

Particularly striking was the apparent lack of interest or fear shown by the birds and animals to even the most violent outburst of the volcano. Horses and dogs evinced no interest whatever. On one occasion the dog of one of the natives accompanied us to the summit of the cone, and while we watched events with considerable trepidation, curled up in the ash and went to sleep. The crows, previously mentioned, during their forays to the cone, showed no apparent concern for explosive bursts from the crater.

The resistance of plantlife to ash varied greatly. During the heavy ash falls of 1943, the trees of the surrounding forests were totally defoliated and appeared dead. After the cessation of heavy ash fall, the oaks and madroñas frequently put out new leaves, but the pines remained dead. Ferns, particularly bracken, showed the greatest resistance to ash. Some herbaceous plants, like chicalote (an argemone), a nicotiana and a gillia, and a coarse rhizomic grass, were able 
to push through a heavy cover of ash and thrive. After the first seedfall of pines, numerous seedlings sprang up and throve. Pines were the first of the forest trees to spring up in the devastated area.

\section{EFFECT ON AGRICULTURE}

Where a heavy blanket of ash covered the fields, the land was lost to agriculture. Corn planted in the ash germinated well but soon withered and died. Fine ash, falling on crops, frequently had a deleterious effect. For instance, fine ash sifting into avocado blossoms inhibited pollenization, and the crop failed. It was reported to us that the sweetpotato plantings at Tancitaro throve, but the plants failed to set tubers. Abrasion of ash on the sugar cane about Los Reyes allowed access to fungi, and the crop failed.

On the other hand, a moderate ash fall proved beneficial. At Zacán, where the ash was only a few centimeters deep, the wheat grew as never before and yielded bumper crops. Although the ash probably contained some nutrient value and acted as a soil conditioner, the principal effect was probably due to its action as a moisture-retaining mulch. A Capacuaro the corn crop, owing to the increment of ash to the soil, proved extraordinarily good.

Great damage was done to the irrigation system about Los Reyes where the ash-laden waters filled the ditches and covered the fields with debris.

The heavy rains of the wet season rapidly washed the ash cover from the open slopes and carried it to the lower valleys. It appears, therefore, that the lower lands will be lost to agriculture for some time to come. The lack of herbaceous cover and the accelerated scouring, owing to the ash-ladened waters, will erode the original soil of the slopes unless judicious plowing is undertaken before erosion removes the top soil. On many of the fields the thickness of ash has already been so reduced that it is feasible to plow the ash cover under and mix it with the original soil. This increment of ash should prove beneficial to the soil.

\section{EFFECT ON HYDROLOGY}

The blanket of ash that covered a wide area was washed by the rains during the rainy season into the arroyos. In many cases this ash was deposited in the arroyos and in extreme cases completely filled them. During periods of heavy rainfall, the waters were heavily laden with ash. Samples collected in Arroyo de Nureto near Angahuan during a heavy rain were about one-half by volume ash. The following table gives some data on water samples from the Río Itzícuaro, near Los Reyes, collected by Ing. Vicente Villaseñor, of the Comisión Nacional de Irrigación, at Morelia. 
Data on some ash-laden waters

\begin{tabular}{r|r|r|r|r}
\hline & Dample collected & Density & $\begin{array}{c}\text { Solids, in } \\
\text { percent }\end{array}$ & \multicolumn{1}{c|}{$\begin{array}{c}\text { Water, in } \\
\text { percent }\end{array}$} \\
\hline & & & & \\
& Aug. 25, 1943 & 1.604 & 60.35 & 39.65 \\
& Aug. 29, 1943 & 1.883 & 71.20 & 28.80 \\
Sept. 1, 1943 & 1.013 & 7.21 & 92.79 \\
\hline
\end{tabular}

The movement of this heavily laden water produced some interesting effects. According to Ing. Villaseñor, the transporting power of the Río Itzícuaro was greatly increased, and large boulders that rested for years in or along the stream bed were easily transported downstream by the river waters. Many of the lands bordering the river were littered with transported boulders, and about San Juan Parangaricutiro some of the fields below arroyos, previously free of cobbles, were littered with boulders brought down by the ash-charged streams. More striking was the finding of boulders in the crotches of trees, mixed with the flotsam of a flood; grass, twigs, and sticks of wood, as well as ash and lapilli, indicating that they were transported during a flood of ash-laden waters.

On the steep slopes of such hills as Cerro de Capatzun, the ash cover was rapidly removed by rainwash, exposing the original soil surface below. Rills and small arroyos developed rapidly in this original soil, owing in part to lack of its original cover of vegetation but also, no doubt, to the scouring effect of the ash-laden waters. Beneath pine trees in many forested areas, an accumulated mat of pine needles in the ash inhibited erosion, and the ash blanket was then more resistant to erosion.

At times, during heavy rainfalls, deep gullies or arroyos formed during a single storm. One such arroyo is shown in plate $47 B$. A single storm could not only excavate a deep arroyo but would sometimes scour the old surface to a depth as much as a meter. In the walls of such arroyos, the layered deposition of ash was well demonstrated, and it was interesting to observe intercalated tongues of cobbles and boulders brought down from nearby slopes of neighboring hills by the ash-laden arroyos.

Because the lava flows completely filled many of the valleys, numerous small arroyos from the side hills were blocked, and ash transported during the rainy season was deposited to a considerable thickness in the small basins thus formed. A line of steam fumaroles in the lava sometimes indicated the original course of the arroyo. These fumaroles disappeared during the dry season.

According to some of the natives of the region, many of the intermittent streams and springs now discharge much more water during 
the dry season than during previous years. This, they state, is particularly true of the area west of the volcano. It was in this direction that the heaviest ash falls occurred. The porous nature of the ash has, undoubtedly, acted to conserve the rainwaters of the wet season. It was frequently noted that even after protracted dry spells the ash remained moist at a very shallow depth.

Mudflows on the steep slopes were rare and then of minor proportions. Occasionally a blanket of ash became sufficiently saturated to flow down the slopes, but in general the ash-covered slopes were remarkably stable. The tilt of dead pine trees on such slopes as Cerro de Canicjuata indicates a slow downhill creep of the ash blanket.

\section{EFFECT ON MIGROCLIMATOLOGY}

Because no weather data seem to have been collected in the area previous to the volcano, no precise changes in the local climate can be specifically noted. The altitude of the area lies between 2,000 and 2,500 meters except for the high Cerros de Tancítaro, the highest point in Michoacán (3,845 meters), which lies immediately to the southwest of the volcano. From this region, the terrain slopes irregularly to the Pacific coast. The area is not well sheltered from the winds that sweep in from the west. The seasons in Michoacán, as in other parts of southern Mexico, are divided into wet and dry periods. The rainy season usually lasts from early June to late September when showers or heavy downpours of rain occur almost daily, frequently accompanied by thunder and lightning. The days begin clear and cloudless, but at midmorning fleecy clouds begin to form. During late morning or early afternoon, the rains occur, the sky becoming clear again in late afternoon. The general concensus of opinion among the natives of the region is that there has been no apparent change in the character of the summer storms or in the quantity of precipitation. During the heavy ash falls of early 1943 , however, it was frequently noted that the first cloud formation took place below the heavy drifting ash cloud (pl. 23A) and was soon followed by cloud formation in all other horizons. There was no positive indication, however, that the ash column initiated or even accelerated any storms. Not infrequer:tly gentle rains of mud were experienced under the heavy pall of drifting ash, sometimes when no rain was apparent in other directions, and even during the dry season. These rains were attributed to condensation of steam in the eruptive column. Rains in the immediate vicinity of the volcano, as at the camp at Cerro de Canicjuata, frequently showed an acid reaction to litmus paper, while rains somewhat farther away, as at San Juan Parangaricutiro, did not. The acid rains had a hardly perceptible sour taste. 
During the rainy season, clouds and fogs drifted in from the west. Occasionally, when the cloudbanks reached the cone, their advance was temporarily halted by the rising column of heated vapors sometimes for a period of an hour or more (pl. $41 B$ ).

Before the advent of Parícutin, the immediate neighborhood was subject to heavy frosts, with frequent development of hoarfrost in the winter. Snowfalls on Cerros de Tancítaro were not unusual. During the period 1943-45, we observed no hoarfrost at Cerro de Jarátiro or other nearby points. The natives agreed that this condition was unusual, because previous winters always brought frosts to Cerro de Jarátiro. Nor were there snowfalls on Cerros de Tancítaro during this period.

One of the most striking effects of the hot lava flows was the development of considerable air turbulence, manifesting itself most obviously in numerous whirlwind columns. As many as ten could be observed at one time. Usually they formed over the ash-covered lava flows. Some rotated rather languidly, others revolved with such force as to tear limbs from the pine trees bordering the flows. Some remained almost stationary; others moved their positions slowly ; many persisted for half an hour or more.

An almost continuous updraft of air toward the cone was observable, particularly in the rising steam column from the fumaroles. Frequently, in the hush of the evening, these vapors collected from all directions to fill the basin about the foot of the cone. Rarely the updraft up the slopes of the cone was sufficiently rapid to form whirlwinds that extended from the slopes of the cone to the lowering eruptive column. This occurred, particularly, when an evident downdraft from the crater met an updraft following the slope of the cone.

\section{LITERATURE CITED}

Bullard, F. M., 1947, Studies on Parícutin volcano, Michoacán, Mexico: Geol. Soc. America Bull., v. 58, p. 433-449.

Carreño, Alfonso, de la $\mathrm{O}, 1943$, El Volcán de Parícutin en las primeras fases de su erupción: Irrigación en México, v. 24, no. 4, p. 49-80.

Flores, Teodoro, and others, 1945, El Parícutin, Estado de Michoacán: México Univ. Nac., Inst. Geología Bol. 37, Mexico City.

Foshag, W. F., and Henderson, E. P., 1946, Primary sublimates at Parícutin volcano: Am. Geophys. Union Trans., v. 27, p. 685-686.

González R., Jenaro, and Foshag, W. F., 1947, The birth of Parícutin: Smithsonian Inst. Ann. Rept. for 1946, p. 223-224.

Hatt, Robert T., 1950, A bibliography of Parícutin volcano: Mich. Acad. Sci. Papers, v. 34, p. 227-237.

Ordóñez, Ezequiel, 1943, El Volcán de Parícutin, Comisión Impulsora y Coordinadora de la Investigación Científica, Anuario 1943, p. 241-300.

_ 1945, El Volcán de Parícutin: Comisión Impulsora y Coordinadora de la Investigación Científica, Mexico, 138 p. 
Ordóñez, Ezequiel, 1947, El Volcán de Parícutin: Editorial Fantasia, Mixcoac, D. F., 181 p.

Perret, F. A., 1912, The flashing arcs: a volcanic phenomenon: Am. Jour. Sci., 4th ser., v. 34, p. 329-333.

Robles Ramos, Ramiro, 1943, El Volcán de Parícutin y el neo-volcanismo Mexicano: Irrigación en México, v. 24, no. 4, p. 81-122.

Sánchez, Pedro, 1935, Importancia Geográfica del "Eje Volcánico": Inst. Pan Am. Geog. and Hist., Pub. 11, 13 p.

Segerstrom, Kenneth, 1950, Erosion studies at Parícutin, State of Michoacán, Mexico: U. S. Geol. Survey Bull. 965-A, 164 p.

Stearns, Harold T., and MacDonald, Gordon A., 1942, Geology and groundwater resources of the island of Maui, Hawaii: Territory of Hawaii, Division of Hydrography, Bull. 7.

Trask, Parker D., 1943, The Mexican volcano, Parícutin: Sci., new ser., v. 98, no. 2554, p. 501-505; reprinted in New York Acad. Sci. Trans., ser. 2, v. 6, no. 12, 1943.

Waitz, Paul, 1943, El nuevo volcán de Parícutin: Irrigación en México, v. 24, no. 4 , p. $37-48$.

White, D. E., 1945, Parícutin's cyclic activity: Am. Geophys. Union Trans., v. 25, p. 621-628.

Wilcox, R. E., 1947, The activity of Parícutin volcano from September 18 to November 30, 1946: Am. Geophys. Union Trans., v. 28, p. 567-569.

Williams, Howel, 1950, Volcanoes of the Parícutin region, Mexico: U. S. Geol. Survey Bull. 965-B, p. 165-279.

Zies, E. G., 1946, Temperature measurements at Parícutin volcano: Am. Geophys. Union Trans., v. 27, p. 178-180 
METRIC EQUIVALENTS

TEMPERATURE

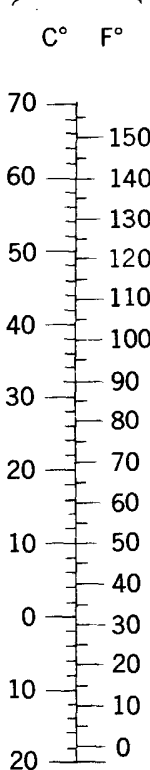

LINEAR MEASURE

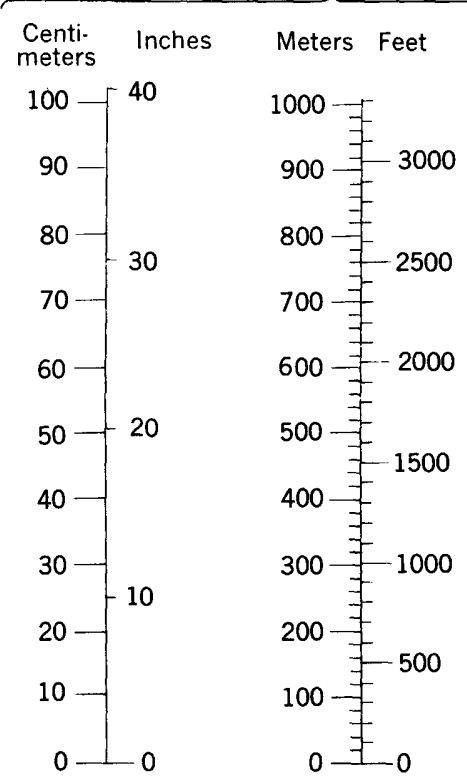

WEIGHTS

Kilo- Miles
meters

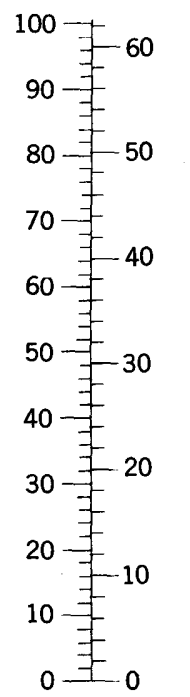

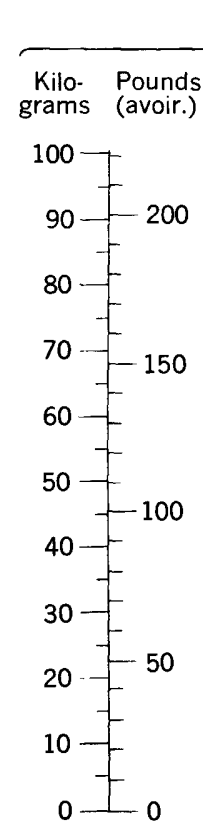

Metric Long

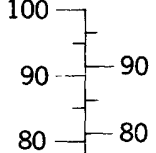

$70-70$

$60+60$

$50-50$

$40 \longrightarrow 40$

$30-30$

$20-20$

$10-10$

$1 \mathrm{~cm} .=0.3937$ inch 1 meter $=3.2808 \mathrm{ft} . \quad 1 \mathrm{~km} .=0.6214$ mile $1 \mathrm{~kg} .=2.2046 \mathrm{lbs} .1$ metric ton $=0.9842$ long ton

1 inch $=2.5400 \mathrm{~cm}$. $1 \mathrm{ft} .=0.3048$ meter 1 mile $=1.6093 \mathrm{~km} . \quad 1 \mathrm{lb} .=0.4536 \mathrm{~kg} . \quad 1$ metric ton $=1.1023$ short tons 1 sq. meter $=1.20$ sq. $y d$

1 cu. meter $=1.31 \mathrm{cu}$. yd

Metric Short $100-100-110$

$90-100$

$8 0 \longdiv { - 9 0 }$

$70-80$

60

$50+60$
$-\quad 50$

$40-50$

$30 \stackrel{-10}{-2} 30$

$20 \div 20$

$10-10$

$0 \stackrel{5}{0}$

long ton $=1.0161$ metric tons

1 short ton $=0.9072$ metric ton 


\section{INDEX}

A

Aa
Acknowledgments
Alkaline reaction of fumaroles....
Alterations, minor rock, associated with

A monium chloride, associated with fumaroles

Anguiano, Juan, account of birth by

A pthitalite, formed at fumarole vents.

Ascents of the main cone

Nov. 26, 1944

Jan. 22, 1945 .

May 27, 1945

(25 $474-475$

Ash . . . . . . . . 395-399, 400, 407, 421, 427, 444, 454, 461 effects of (see also Effects of Parícutin _ _ _ 399 , $481,461,462$ erosion of $463,465-466$

weight of, Feb. 20-Oct. 20, 1943. $422-424$

August activity, Quitzocho period.

\section{B}

Basalt

Bibliography 484-485

Birth of Parícutin, accounts by eyewitnesses.

373-385

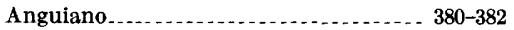

Cuara, Aurora. . . . . . . . . . 378-380

Gutiérrez, Celedonio _......... 382-383, 387, 388

Martínez........ 380-382

Pulido, Dionisio........... 375-377

Pulido, Dolores.................... 378

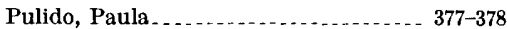

record of San Juan Parangaricutiro . . . . 383-384

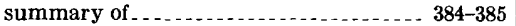

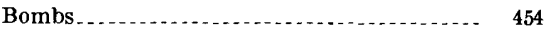

during cineritic phase................ 397

during Quitzocho period................ 422

during Sapichu eruptive activity . . 434-435, 436

during Taquí period ................... 444

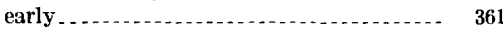

shapes of . . .

sounds made by ......

\section{C}

Chadbourn, Erma, analyses of early bombs by

Chlorides, associated with fumaroles

Cineritic phase, heavy, Quitzocho period .. 395-399

Cone, slumping of . . . . . 395, 400, 401, 409-411, 416, 422

Corral, Mesa del, flow.

vent, slumping of cone at.
00 Crater, main, ascent of . . . . $4 . . .42$

Nov. 26, $1944 \ldots \ldots \ldots 4$

Jan. 22, $1945 \ldots \ldots$. $\ldots 43-474$

May 27, 1945 . . . . $474-475$

activity of. (See Taquí period, Sapichu

period, and Quitzocho period.)

Crater, north, reopening of .............. 411

Cuara, Aurora, account of birth by . . . . . $378-380$

Cuiyúsuru, Llano de, description of . . . . . - 370-372

Cuiyúsuru-Quitzocho valley, description of _ $370-372$

\section{D}

Development of Paricutin volcano (see also Taquí period, Sapichu period, and Quitzocho period). $385-479$

\section{E}

Earthquakes

365 , $373-374,388,432-433,446,453-454,455$

Effects of Paricutin . . . . . . . . . . . . . $479-484$ agriculture............. 481 hydrology . . . . . . . . . . . . . . . . . . . . . . . . $481-483$ life . . microclimatology . . . . . . . . . . . . . . . 483-484 Erosion, rain (see also Effects of Parícutin) _.. 465-466 Explosive phase, early, Quitzocho period. . 386-395 Eyewitresses, positions of, at volcano's birth (see also Birth of Paricutin) ........ 379

\section{F}

Faroles, Los .

Fieldwork $\ldots \ldots \ldots$. $356-359$

Fissures . . . . . . . . . . . . . . . . 446

Flashing ares . . . . . . . . . . . $390,400,421,422,424$

Flores, Teodoro, quoted . . . . . . $392-393$

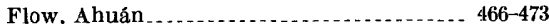
La Lagunita . . . . . . . . . 407, 408, 409, 416-418, 433 Mesa del Corral..................... 398 Parangaricutiro lava tongue . _ . _ _ _ _ . 458-460

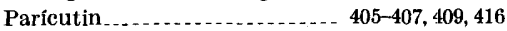

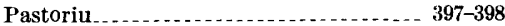
Quitzocho (see also Quitzocho period) _ _ 360-362, 428 Sapichu (see also Sapichu period) _. . . . . 360-361 Taquí (see also Taquí period) .............. 360, $441,445-453,463,464,475-477$ Tititzu . . . . . . . $419-421$ Fluorides, associated with fumaroles ......... 362 Fountains, lava . . . . . . . . . . . . . . . 408, 426, 451 Fumaroles...... 361-363, 394, 396-397, 408, 418, 438, 442

G

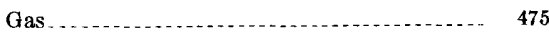
Geography, pre-Parícutin _... $369-372$ 
Geology, pre-Parícutin

Gutierren Celedonio, quoted . ...... 382-383, 387, 388

\section{$\mathrm{H}$}

Hematite, formed at fumarole vents . . . $363,457,468$

History, pre-Parícutin 364-373 geography, local . . . . . $\ldots \ldots \ldots$. $369-372$ geologic setting . . . . . volcanic axis.

Hornitos $449,457-458,468,470$

Hornitos, Mesa de Los

Horno, Peña del $452,457,470,476$

Hydrochloric acid, associated with fumaroles

Hydrogen sulfide. 362,437

I

Introduction 356-364

Investigations, fieldwork 356-359 previous

Jarátiro, Casita

J

Jarátiro, Cerro de, covered by Taquí flow

July activity during Quitzocho period. $416-422$

$\mathbf{K}$

Kipuka

\section{L}

Lagunita, La......... 371 covered by lava $\ldots \ldots \ldots \ldots \ldots \ldots \ldots$. . . . . . . 411,413 flow . . . . . . . . . . . . . . . 407, 408, 409, 416-418, 433

Lava, aa $\ldots \ldots \ldots$. . . . . . . 360 covering Turímbiro ................. 416 during explosive phase . . . . . . . . . . . . . . . 393-394 early . . . . . . . . analysis of . . . . . .

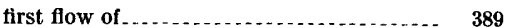
first week of . . . . . . . . . . . . . . . . . . 391-392 flow of down Arroyo Principal ....... 459 Parícutin Arroyo. ................. 405, 418 fountains..................... $408,426,451$ pahoehoe ............................. 452 Quitzocho flow (see also Quitzocho period). 360-

Sapichu (see also Sapichu period) ..... . . 360-361 Taquí vents (see also Taquí period) ....... $360-$ $361,441,445-453$ sounds made by when erupted . . ........ 364 weight of Feb. 20-Oct. 20, 1943 .......... 431

Lightning . $364,379,447,471,476$

Los Faroles 419,422

Luminous phenomena (see also flashing ares) $455-$

\section{$\mathbf{M}$}

Magnetite, formed at fumarole vents. 363,468

Martinez, Jesús, account of birth by $380-382$

Mesa de Los Hornitos. (See Hornitos, Mesa de Los.)

Mexican Volcanic Axis. 364-366

Michoacán volcanic province, hitory of . _- $366-369$ Mud fall.

$$
\text { o }
$$

Observers of development, list of .
Ombligo

\section{$\mathbf{P}$}

Pahoehoe lava ............................ 452

Parangaricutiro lava tongue .............. 458-460

Paricutin, description of . . . . . . . . . . . 369 dispute with San Juan Parangaricutiro. 372-373

Paricutin Arroyo. . . . . . . . . . . . . . . 371 lava flowing down $\ldots \ldots \ldots \ldots . . \ldots 4,418$ Parícutin flow .................... 405-407, 409, 416 Pastoriu flow ......... . . . . . . . . . . . . . . 397-398 Peña del Horno............................... 372 Pre-Parícutin history (See History.)

Pough, Frederick H., quoted..... 415-416, 450-451 Principal, Arroyo, flow of lava down ....... 459 Pulido, Dionisio, account of birth by . ..... 375-377 Dolores, account of birth by ............ 378 Paula, account of birth by ............. 377-378

\section{Q}

Quitzocho, Llano de, description of . . ..... 370-372 lava flow over. . . . . . . . . . . . 393-394, 398, 411

Quitzocho flow . . . . . . . . . . . . . . . . $360,361-362$ covered by ash . . . . . . . . . . . . . . . . . 400 explosive activity during ................ $\quad 395$ first advance of..................... 394 fumaroles in . . . . . . . . . . . . . . . . . . . $361-363$

Quitzocho period .......... 386-432 activity of July ................. $416-422$

Lagunita, La, flow . . . . . . . . . . . 416-418

Parícutin Arroyo ................... 418

Quitzocho ridge .................... 418

Tititzu flow . . . . . . . . . . . . . . . . 419-421

Turímbiro, lava covering ........... $\quad 416$

activity in August.......... . . . . . . . 422-424

Quitzocho ridge $\ldots \ldots \ldots \ldots$. . . . . . . . . $422-423$

slumping of cone................. 422

activity of September-October . . . . . ... 424-427 cineritic phase

March 18........................ 395

bomb fall during . . . . . . . . . . . . 397

Mesa del Corral flow . . . . . . . . . . . . . 398

Pastoriu flow . . . . . . . . . . . . . . 397-398

rains during . . . . . . . . . . . . . . . . . . 396-397

winds during. ....................... 397

explosive phase $\ldots \ldots \ldots$. $386-395$

February 21 . . . . . . . . . . . . . . $386-388$

February 22 . . . $\ldots \ldots$. $388-389$

February 23 . . . . . . . $38 . \ldots$

February $24 \ldots \ldots . \ldots 89$

February 25 . . . . . . . . . . . . . . . 389,390

February 25 to March 5 . . . . . . . . . . 392-393

February $26 \ldots \ldots$

February 27 ...................... 390

February $28 \ldots \ldots . .390,392$

explosions, types of . . . . . . . . . . $389-390$

flashing arcs.................... 390

lava flow . . . . . . . . . . . . . . . . . . . 393-394

Quitzocho ridge.............. . . 415-416

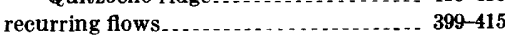

June $9 \ldots \ldots \ldots$. . . . . . . . . . . . . . . . . . . . . . $399-400$

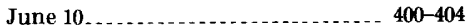

June $11 \ldots \ldots$. . . . $404-405$

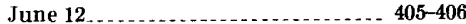

June 13... . . . . . . . . . . . . . . . . 407 
Quitzocho period-Continued recurring flows-Continued

June 14

June 15

June 16

June 17

June 18

June 19

La Lagunita flow

Parícutin flow .

Quitzocho ridge........... 401-404

summary of

cineritic phase....... 428

explosive phase $\ldots \ldots \ldots \ldots$

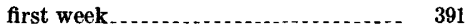

Quitzocho flow . ............... 428

Quitzocho ridge.... . . . . . . . . . . 431-432

recurring flows ..................... 428-431

Quitzocho ridge

401-404,

$415-416,418,419,422-423,431-432$

Quitzocho-Cuiyúsuru valley, description of - 370-372

\section{$\mathbf{R}$}

Rain, during cineritic phase

396-397 erosion. $465-466$

Ramos, Robles, quoted 390

\section{$\mathrm{S}$}

San Juan Parangaricutiro, ash fall on ......... $\quad 399$ description of . ....................... 369

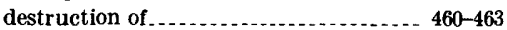
dispute with Parícutin ............. . . . . 372-373 record of birth by ..................... 383-384

Sapichv period, crater of Sapichu. .......... 440-442 eruptive activity of Sapichu........... 434-440

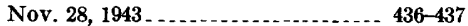

Nov. 29.

Nov. $30 \ldots \ldots \ldots \ldots$. $437-438$

Dec. 1 _......

Dec. 2 $2 \ldots \ldots \ldots$

Dec. $3 \ldots \ldots \ldots$ 438-439

Dec. $4 \ldots \ldots . . . \ldots 49$

Dec. 5............... $439-440$

ash ................................ 435

bombs....

lava................. 360

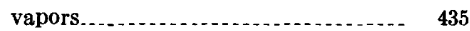

Sapichu vents . . . . . . . . . .

earth tremors....................... 432-433

Lagunita flow, elevated by injection.- $\quad 433$ summary... 443-444

September-October activity during Quitzocho period
Page

Slumping of cur1: .... 395, 400, 401, 409-411, 416, 422 Sol, Piedra de . . . . . . . . . 370

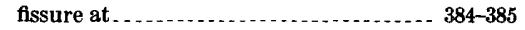

Solorio, Luis Ortíz, account of birth by ...... 380

Soplete................... 452,453

Sounds made by volcano . . . . . . . . . . . . . 363-364

South vent . ................... 409, 411

Strombolian type activity .................. 443

Sulfur dioxide. ........................... 438 associated with fumaroles............... 362

Sulfur trioxide, associated with fumaroles..... 362

Taquí period . . . . . . .

Ahuán flow .......................... 466-473

crater activity ......................... 454-457

Nov. 26, 1944 . . . . . . . . . . . .

Jan. 22, 1945 . . . . . . . . . . . . . . . . . . 473-474

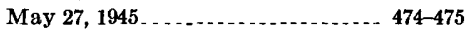

hornitos . . . . . . . . . . . . . .

luminous phenomena (see also Flashing ares)

Parangaricutiro lava tongue . . . . . . . . . $458-460$

rain erosion .......................... 465-466

San Juan Parangaricutiro, destruction of

summary .................. $477-479$

Taquí lava flow_360, 441, 445-453, 463, 464, 475-477 late state of .............. $463,464,475-477$

Taqui vents...................... 444-446, 475

tremor zone. . . . . . . . . . . . . . . . $453-454$

volcancitos ............

Temperature, fumaroles. . . . . . . . . . . . . . . 362,363

hornitos ................................. 468

surface of small bomb.................. $\quad 397$

Thenardite, formed at fumarole vents . . . .... $\quad 363$

Tititzu flow ........................... 419-421

Tremor zone (see also Earthquakes) _ _ _ 466, 453-454

Turimbíro, lava covering.

Vapors.................. 445

sounds made by when erupted.......... 364

Taqui lava flows . ..................... 449

Volcancitos........... 449, 452, 453, 457-458, 470 discharging flow of Ahuán lava....... 472-473

in Taquí flow....... 475

Volcanic axis . . . . . $364-366$

\section{W}

Whirlwinds . ...................... 404, 424, 437

sounds made by . . . . . . .

White, Donold, quoted................. 426-427

424 Winds, during cineritic phase $\ldots . . . \ldots \ldots \ldots$ 
PLATES 16-51 

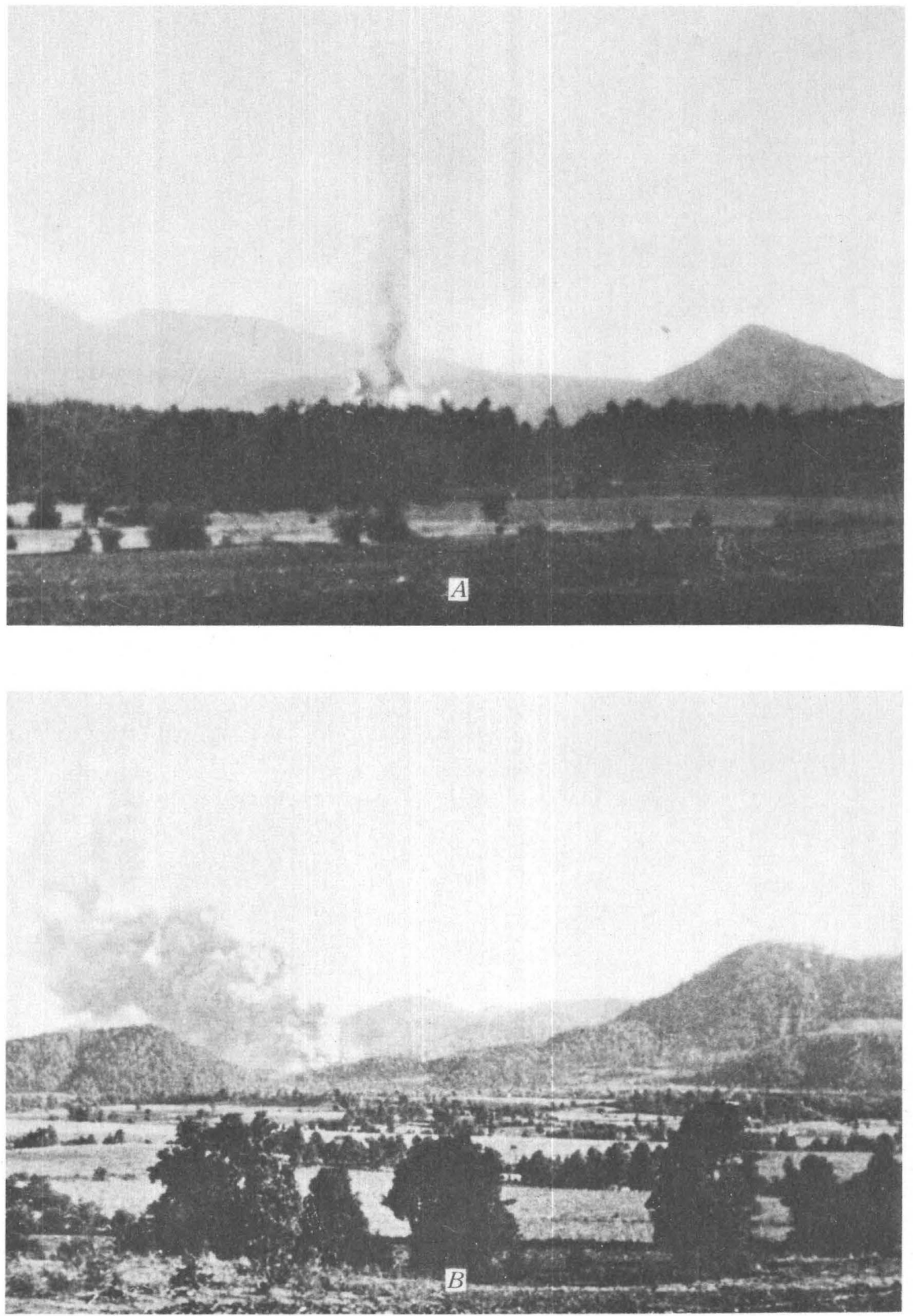

\section{ERUPTIVE COLUMN OF PARÍCUTIN VOLCANO}

A.-February 20,1943. The new volcano broke forth in the valley of QuitzochoCuiyúsuru, which lay between Cerro de Jarátiro (left), Cerro de Camiro (far center), and Cerro de Canicjuata (right). Parícutin village lies near the foot of Cerro de Canicjuata. The fields of San Juan Parangaricutiro are in the foreground. Taken from Ticuiro, near San Juan Parangaricutiro, at 5 p. m.

B.-Same area photographed one-half hour later. 

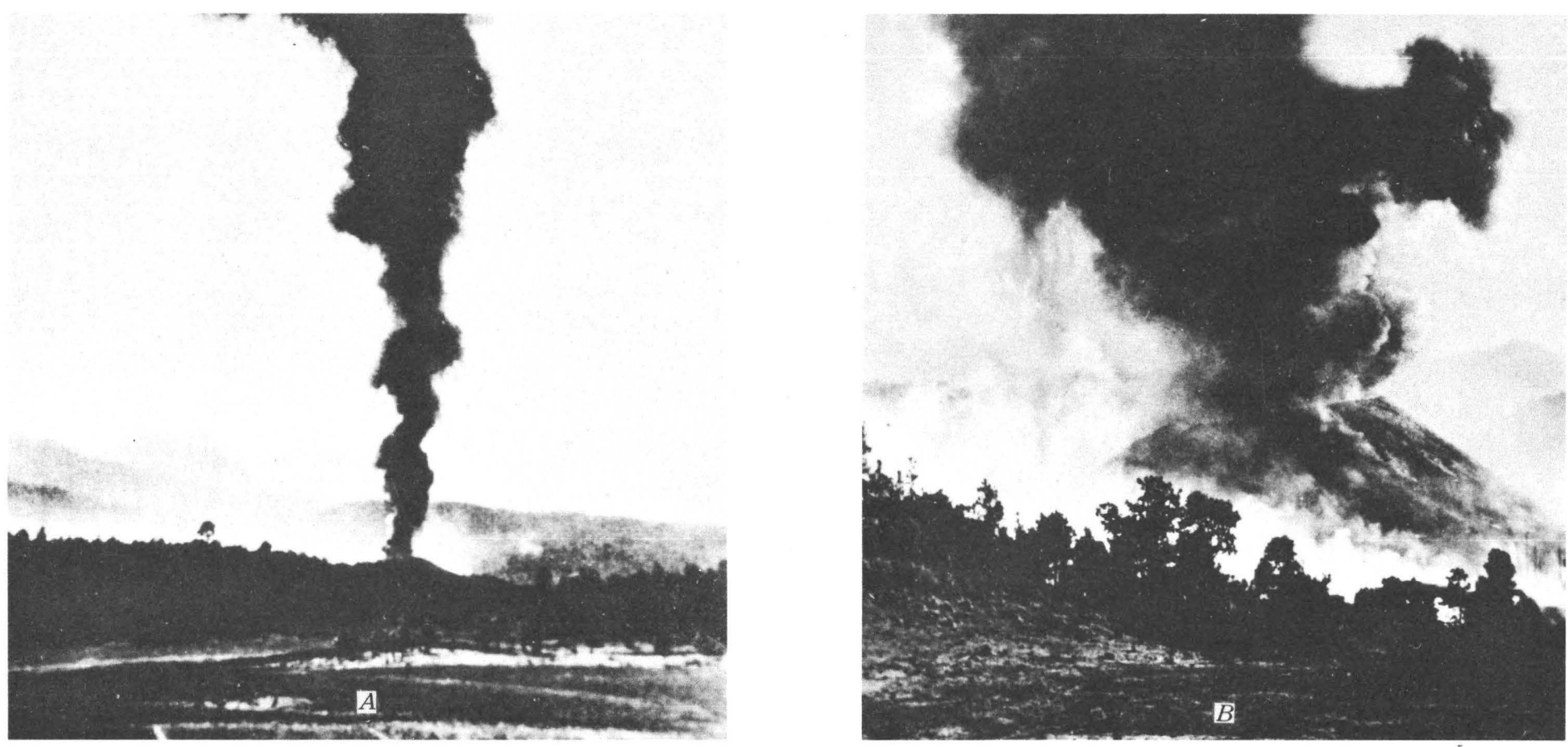

\section{THE NEW CONE}

A.-February 21, 1943. The new cone, about 30 meters high, appears above the treetops. Taken from the northeast. Photograph by Salvador Ceja.

B.-February 22, 1943. The new cone viewed from the northeast. Great quantities of ejected bombs and lapilli caused the new cone to grow rapidly. Vapors of the first (Quitzocho) lava flow are around the base of the cone. Cerros de Tacítaro in the right background. Photograph by Rufus Morrow. 

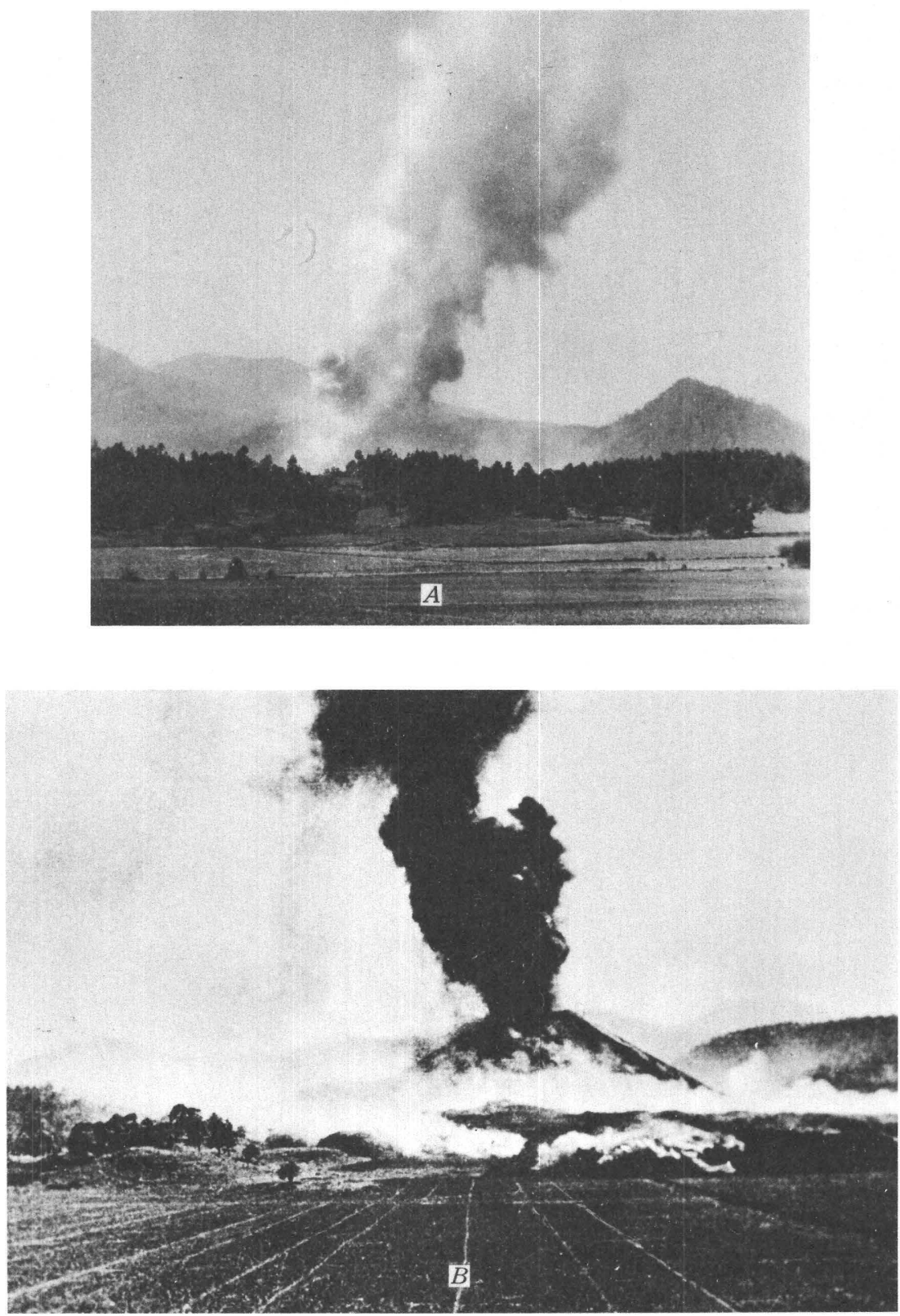

\section{ERUPTIVE COLUMN}

A.-February 24, 1943. Vaporous eruptive column with little ash. Taken from the northeast. Photograph by Ezequiel Ordónez.

B.-February 23, 1943. Heavy emission of bombs with moderate eruptive column. Llano de Quitzocho in the foreground; Quitzocho lava flow with abundant fumaroles in the middle ground. View from the northeast. Photograph by Ramiro Robles Ramos. 

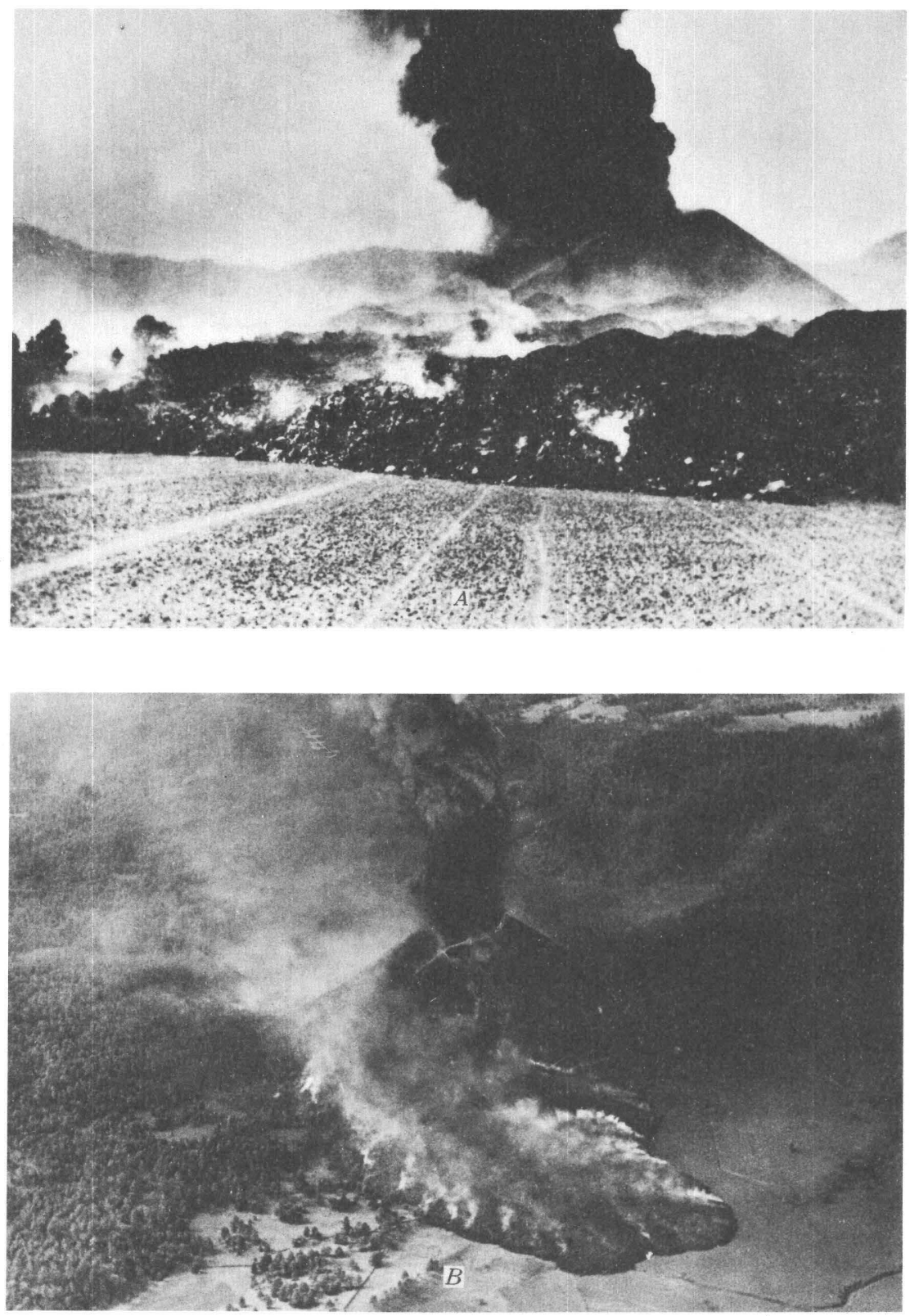

\section{HORSESHOE-SHAPED CONE AND QUITZOCHO LAVA FLOW}

A.-March 2, 1943. Heavy bomb and lapilli emission. The horseshoe shape of the cone is apparent. Quitzocho lava flow in middle ground. Note the sparse cover of ash in the cultivated fields. Taken from the northeast. Photograph by Instituto de Geología.

B.-March 5, 1943. Air view of the cone from the northeast. Quitzocho flow in the foreground with fumaroles around its periphery; Cuiyúsuru, right; Teruto, middle ground. Photograph by Ezequiel Ordoñez. 

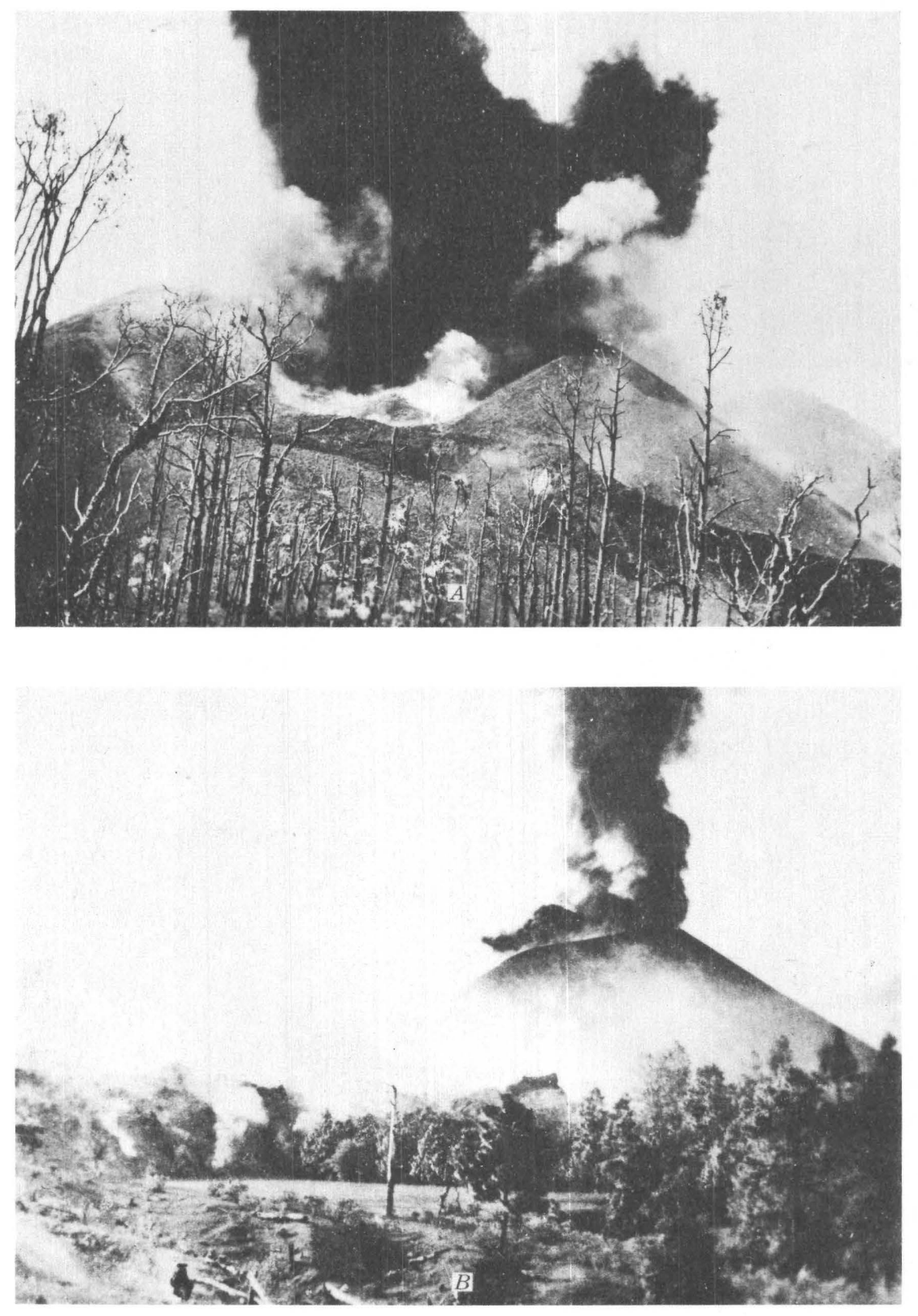

\section{QUITZOCHO LAVA FLOW}

A.--March 10, 1943. Breached eastern side of cone showing the crater and hummocky surface of Quitzocho lava flow. In the foreground are the remains of a forest destroyed by bomb and lapilli falls. Photograph by Ezequiel Ordónez.

B.-March 20, 1943. The Quitzocho lava flow has almost reached its maximum extent at the foot of Cerro de Jarátiro. The cone is still asymmetrical owing to repeated breaching. Taken from the eastern foot of Cerro de Jarátiro. 

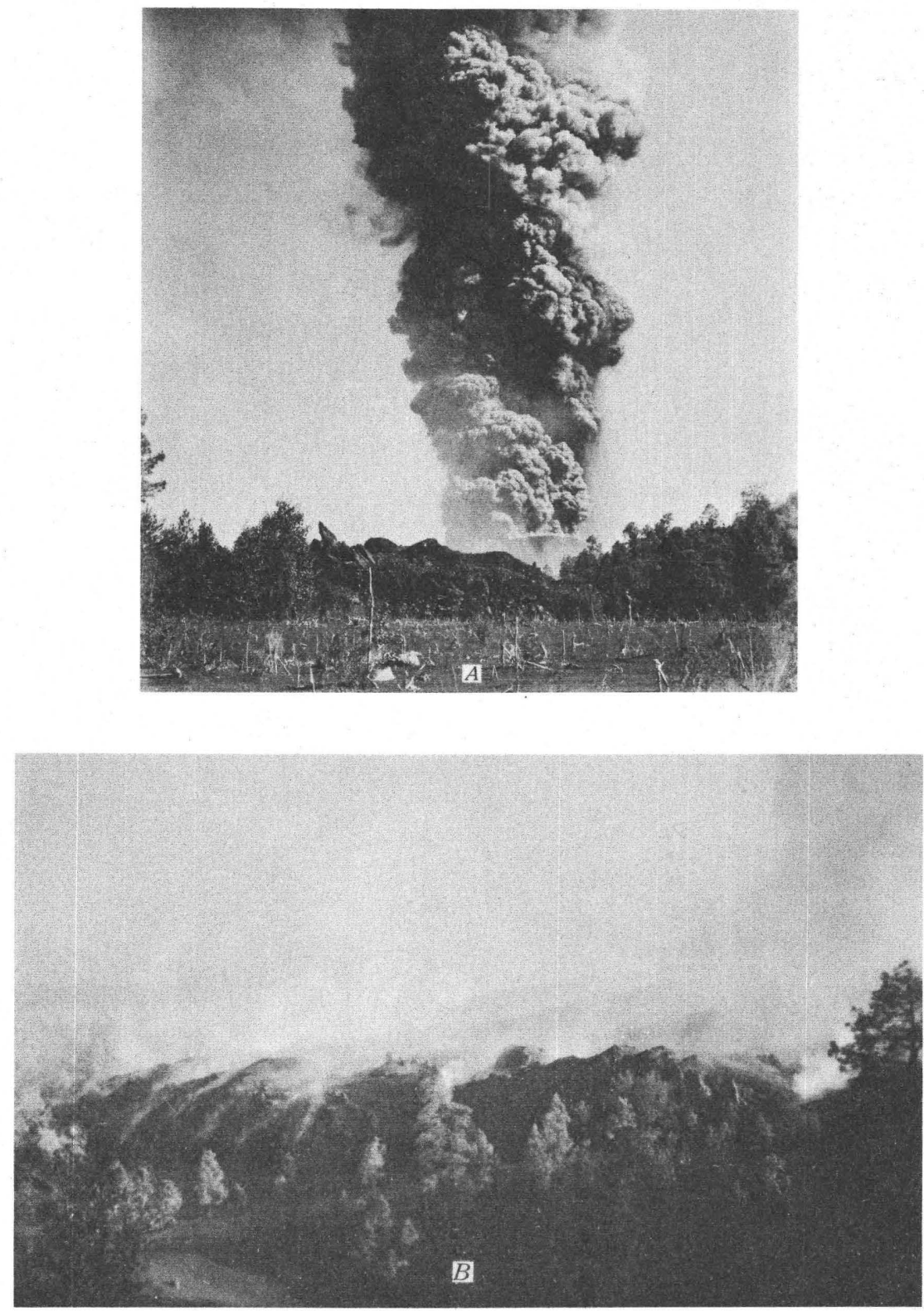

\section{ERUPTIVE COLUMN AND QUITZOCHO LAVA FLOW}

A.-March 24, 1943. Tremendous cineritic activity, with eruptive column 6 kilometers high. Front of the Mesa del Corral lava flow in the middle ground. Taken northward from Tititzu.

B.-March 24, 1943. Front of Quitzocho lava flow at the foot of Cerro de Jarátiro. The rugged flow is partially covered with ash. Fumaroles are situated about its periphery. 

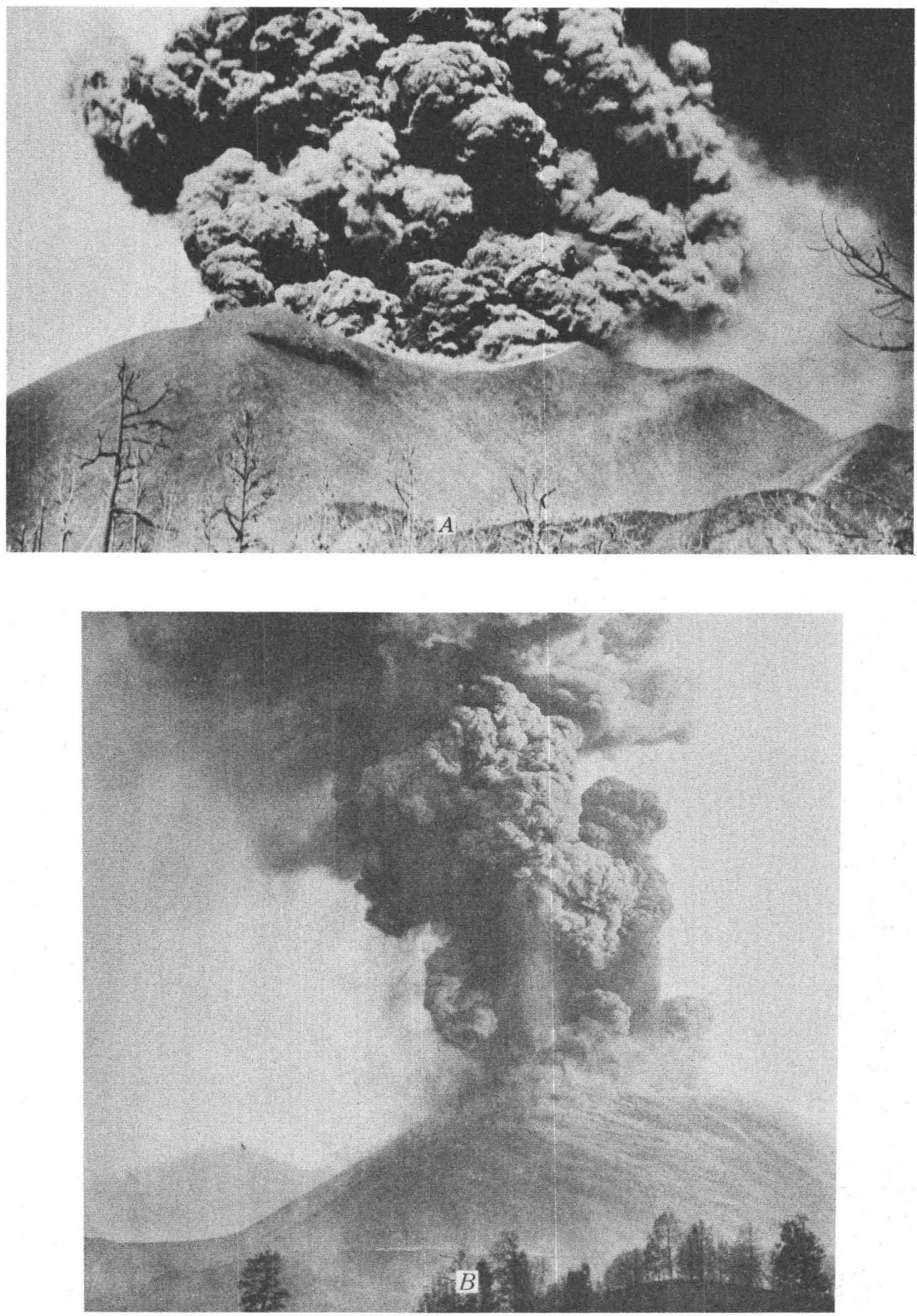

\section{HEAVY CINERITIC ACTIVITY}

A.-April 22, 1943. The breached cone, now partly restored, and the inner cone or "ombligo." Very heavy cineritic activity. Taken from the south. Photograph by L. C. Graton.

B.- May 24, 1943 . Heavy cineritic activity, accompanied by abundant bombs. Taken from Cerro de Jarátiro. 

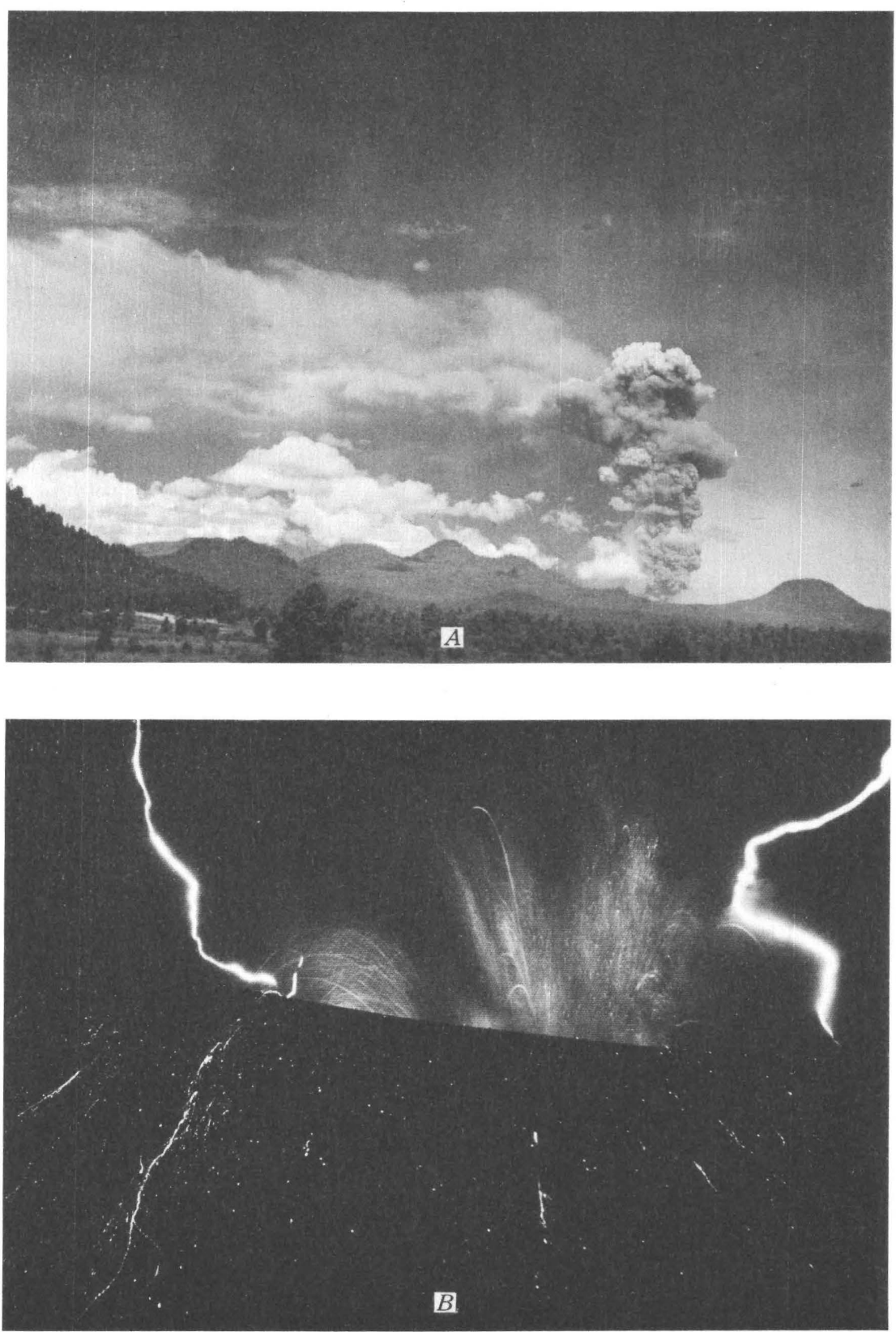

\section{ERUPTIVE COLUMN}

A.-June 9, 1943. Eruptive column from the Uruapan highway. Plume of drifting ash to the south and clouds forming beneath it. Extinct volcanic cones in the middle distance. Taken from the east.

B.-May 25, 1943. Lightning flashes were frequent in the dense swiftly rising eruptive column. Photograph by Rafael García. 

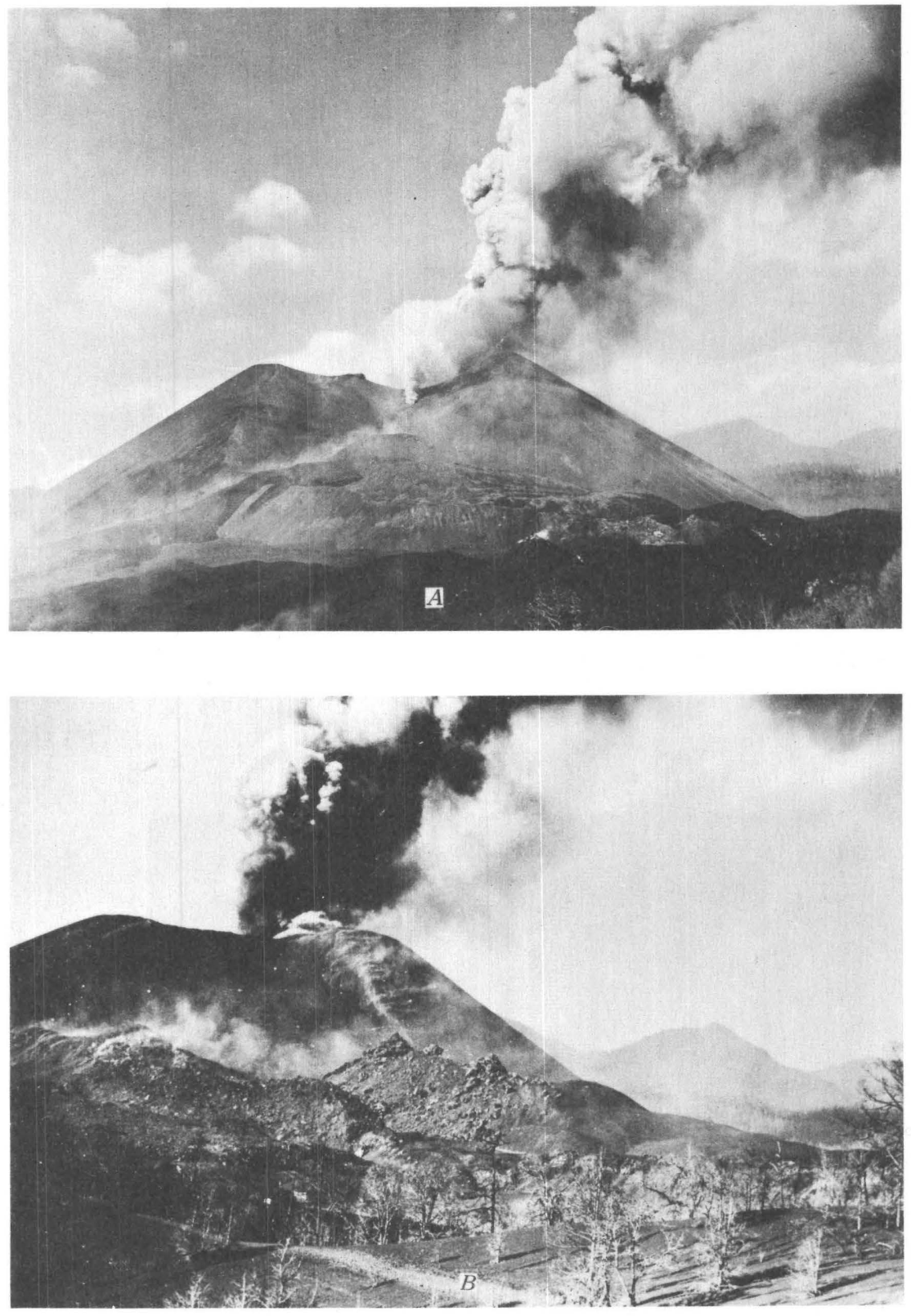

BREAKS IN THE CONE

A.- June 19, 1943. Flow from vent high on the broken cone; vapors are being emitted from the north and south crater vents. Broken terraces are in the middle distance and the smooth domes of the Quitzocho ridge to the right; the ash-covered Quitzocho lava in the foreground. Taken from Cerro de Jarátiro, B.-July 10, 1943. A later break in the cone. The rock peaks, "Los Faroles," once a part of the cone, are now part of Quitzocho ridge. Taken from Cerro de Jarátiro. Protograph by Ezequiel Ordóñez. 


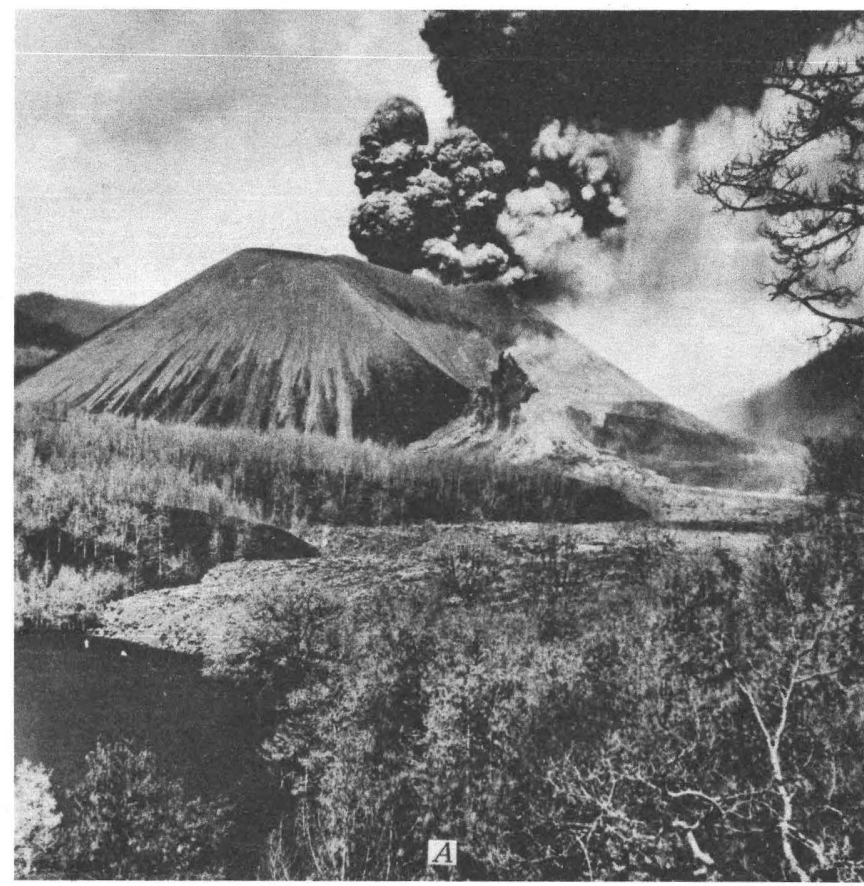

PARTLY RESTORED BROKEN CONE

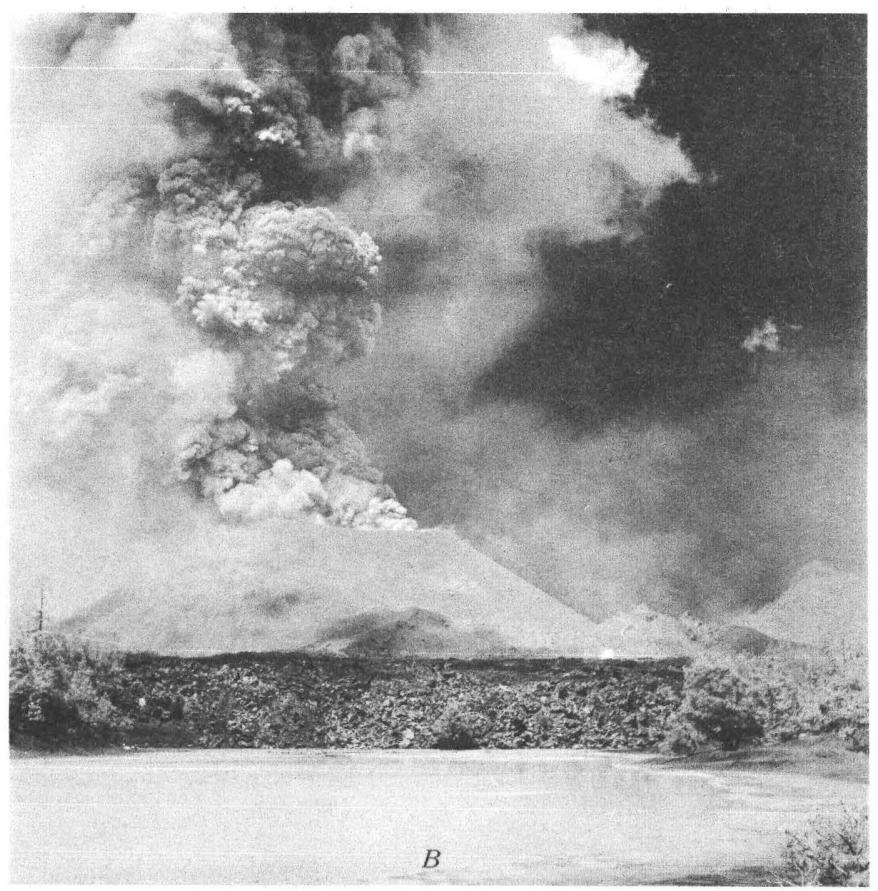

CINERITIC ACTIVITY

A.-June 28, 1943. The broken cone, viewed northeastward from Cerro de Curupichu after the break of June 10, is now partly restored. Lava issues from a vent high on the flank of the cone (the Lagunita flow) and spreads out in the valley below. Photograph by Arno

B.- July 25, 1943. Heavy cineritic activity. The Quitzocho ridge from the base of the cone to the right. Note small pond formed by a lava dam. Photograph taken from the northeast. 

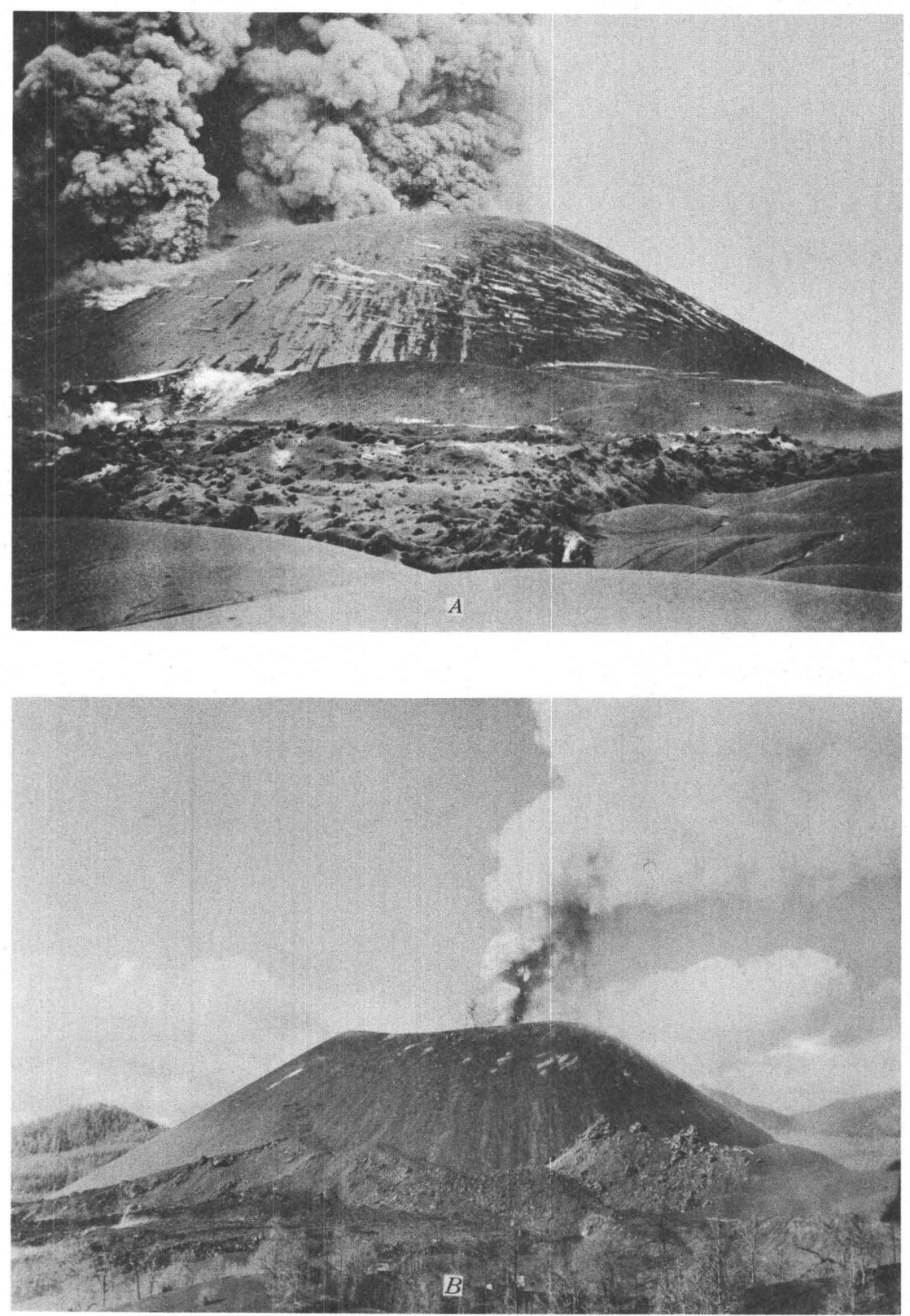

\section{NORTH FLANK CHIMNEY AND HEAVY EXPLOSIONS WITH LARGE BOMBS}

A.- Early July. Chimney on the north flank of the cone on the site of one of the eruptive vents of June, after the cone had been restored by uninterrupted ash fall. Lava of June on ash-covered lavas of the Quitzocho flow. View from Cerro de Jarátiro. Photograph by Ezequiel Ordóñez.

B.- July 31, 1943. Heavy explosions with large bombs and moderate vaporous eruptive column. The break of the cone of early July now largely restored. An old crater of Cerro de Jarátiro in the foreground. Photograph taken from Cerro de Jarátiro. 

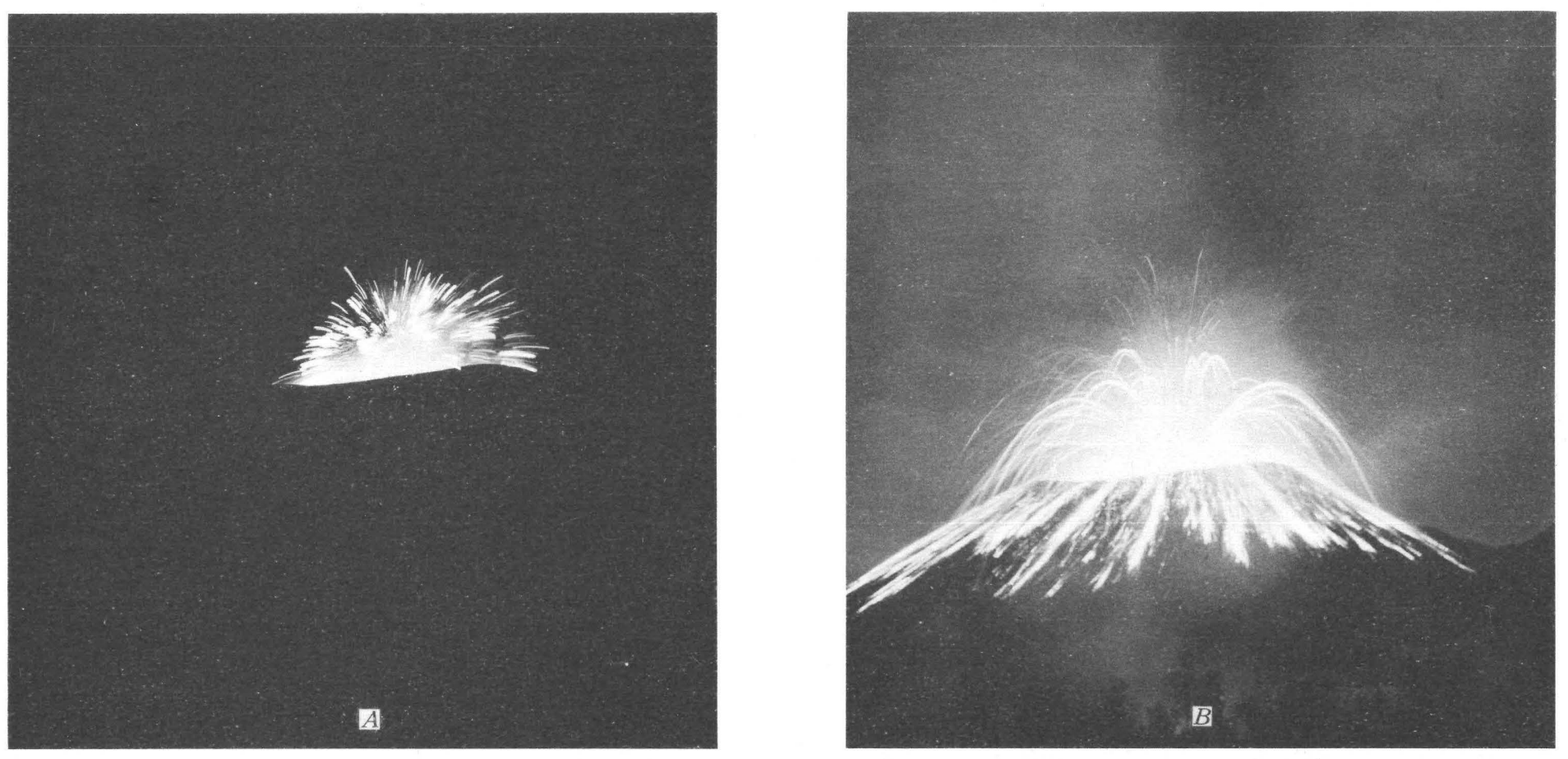

LAVA BUBBLES BURSTING IN CRATER

A.-August 1, 1943. Tremendous bursts of huge lava bubbles in crater, accompanied by flashing ares, yielding huge tatters of viscous lava. Photograph taken from Cerro de Jarátiro.

B.-Same as above; time exposure about 15 seconds. Ejected masses of viscous lava flow down the slopes of the cone. Dark area in upper center is a weak eruptive column. 

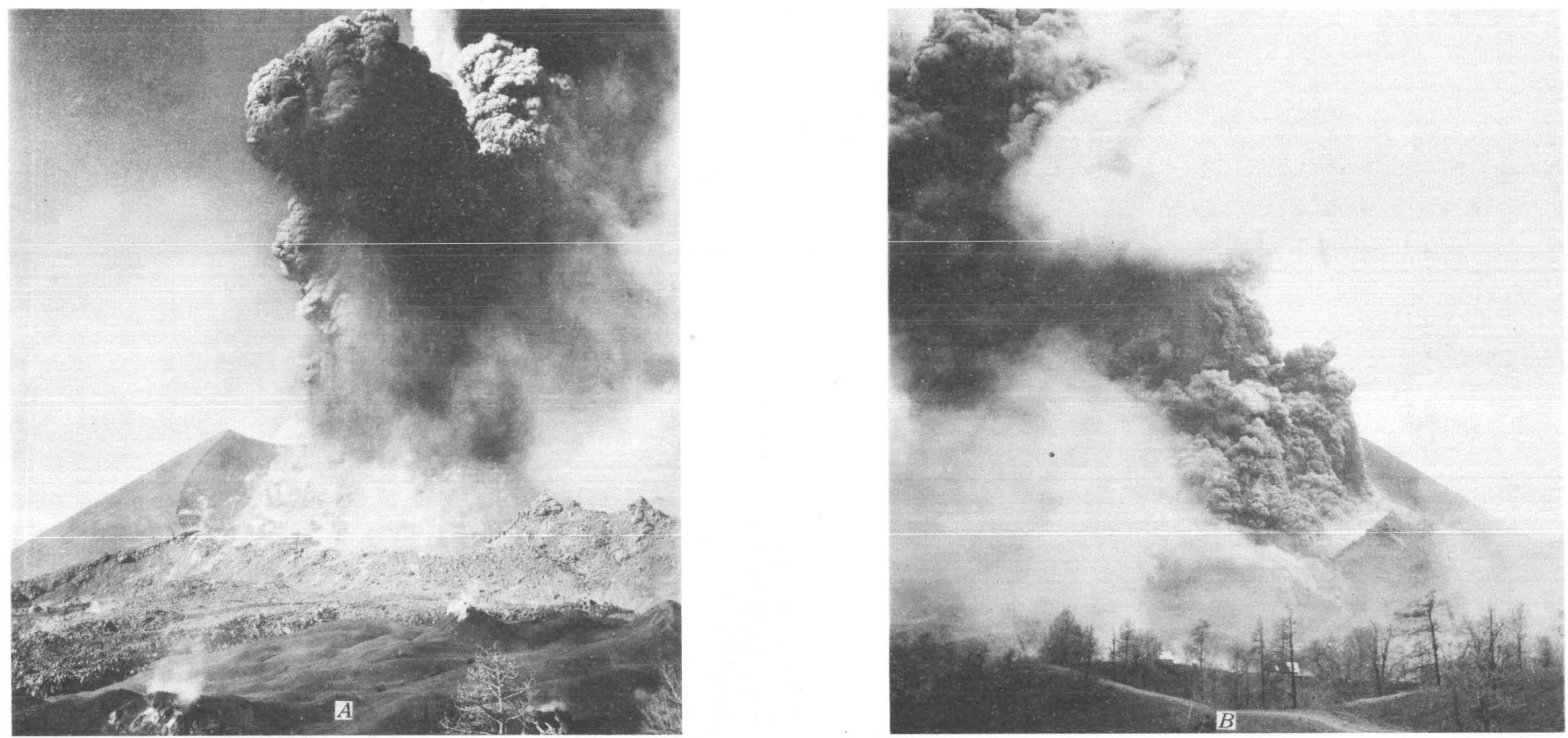

BREAKS IN THE CONE

A.-July 26, 1943. Cone viewed from Cerro de Jarátiro after the break in late July. Tremendous explosion from the north crater vent and heavy emission from south vent. Quitzocho ridge in the middle ground; ash-covered Quitzocho lava with salt-incrusted fumaroles in foreground.

B.-August 2, 1943. The break in the cone in early afternoon. Huge jets of black ash play from the broken segment of the cone. The rocks, "Los Faroles," that crown the ridge are beginning to move to the left. One of the craters of Cerro de Jarátiro is in the foreground. Photograph taken from Cerro de Jarátiro. 

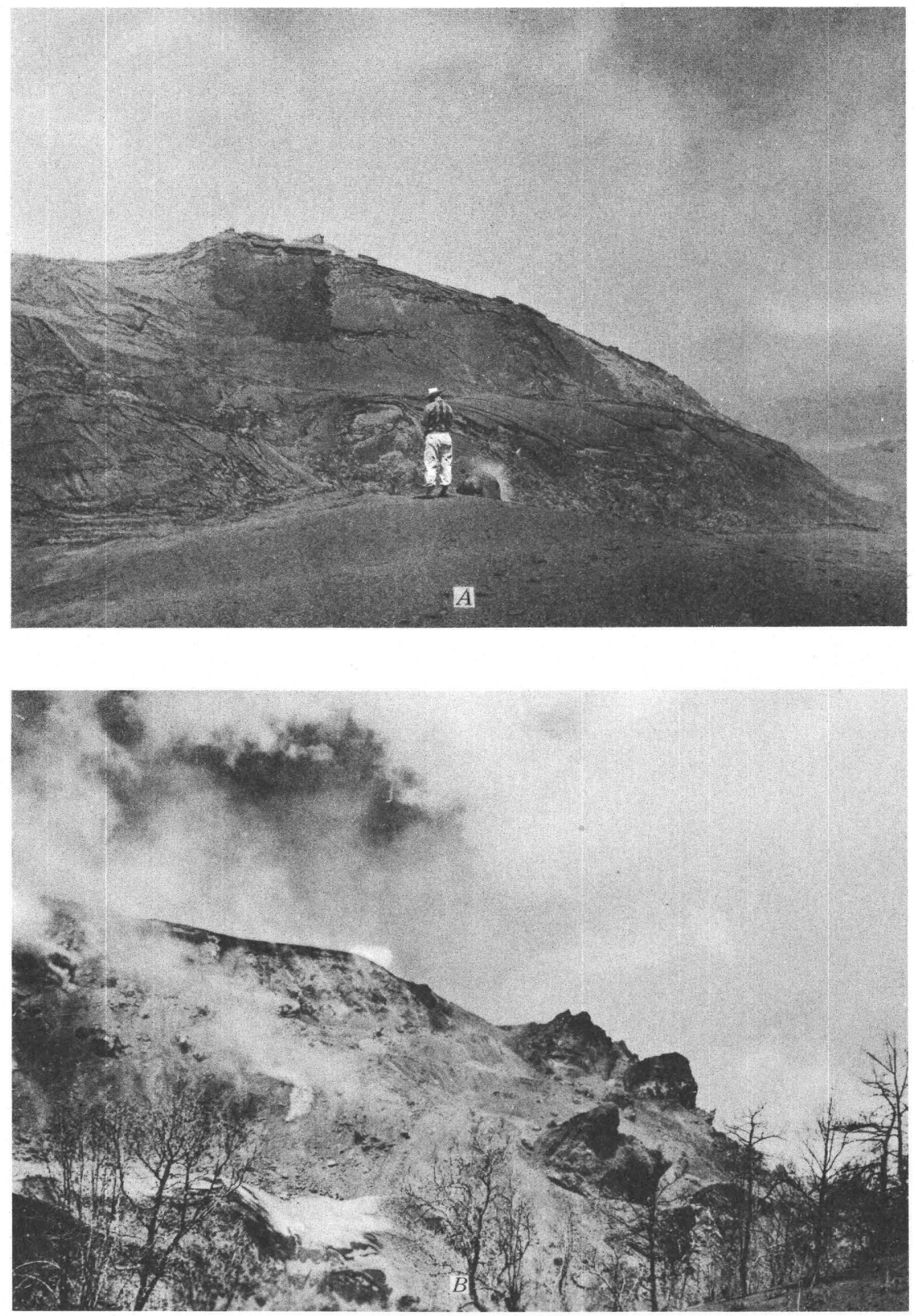

\section{EARLY AND LATE STAGES OF QUITZOCHO RIDGE GROWTH}

A.-June 10, 1943. Early stage in the growth of Quitzocho ridge by injection of lava below the ash during the lava outbreak of June 10 .

B.-August 25, 1943. Late stage in the growth of Quitzocho ridge. The large blocks at the ridge terminus are of disintegrating lava. The dust, left center, is from boulders displaced by the elevation of the ridge. The foot of Cerro de Jarátiro is to the left. Photograph by Ezequiel Ordóñez. 

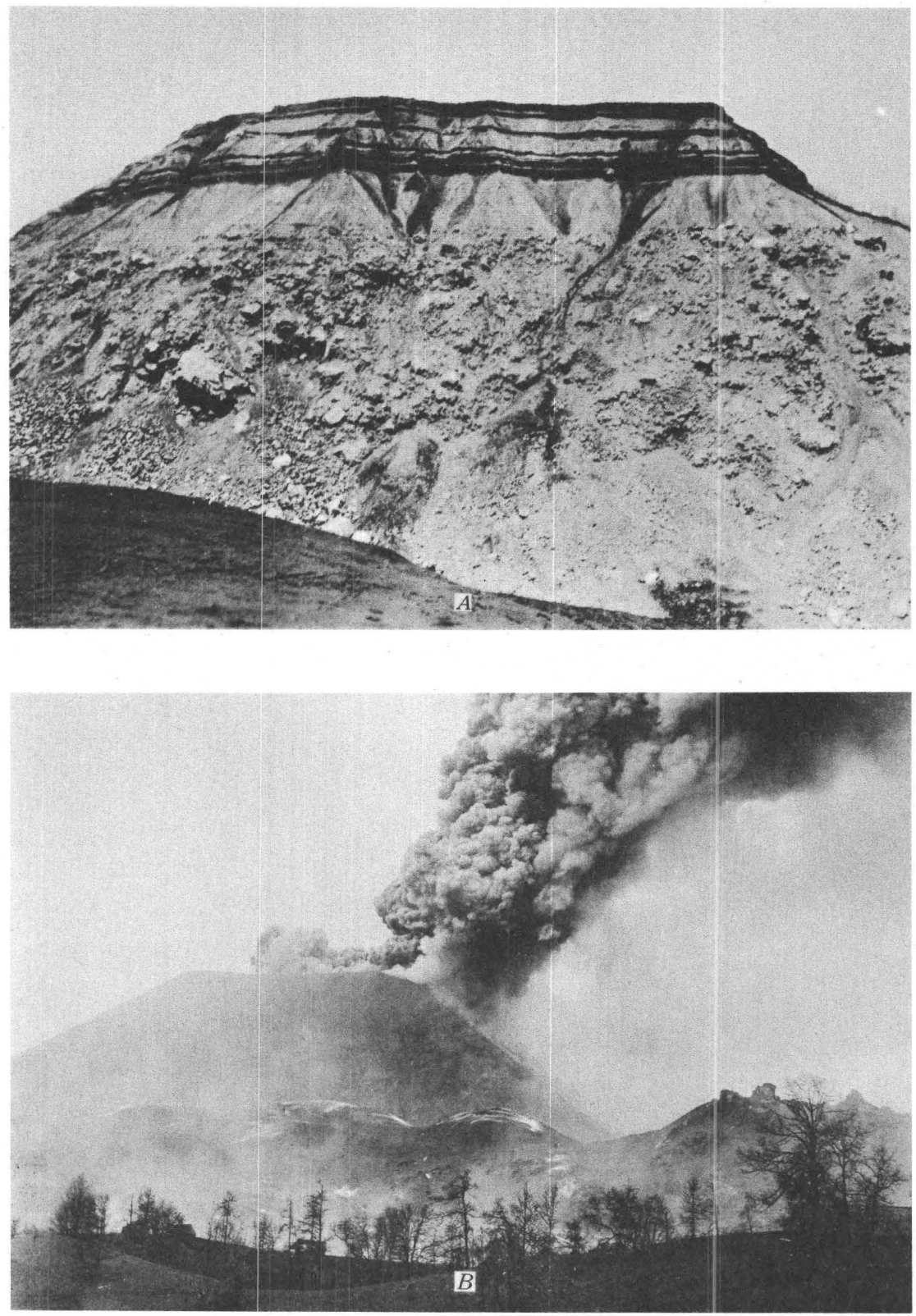

\section{QUITZOCHO RIDGE}

A.-September 1943. Portion of Quitzocho ridge showing elevated stratified ash 'on top and disintegrated lava below. Photograph by Ezequiel Ordóñez.

B.-September 17, 1943. Lazy emission of ash-laden eruptive column. On the right is part of the Quitzocho ridge with "Los Faroles" at the right. Old crater of Cerro de Jarátiro in foreground. 

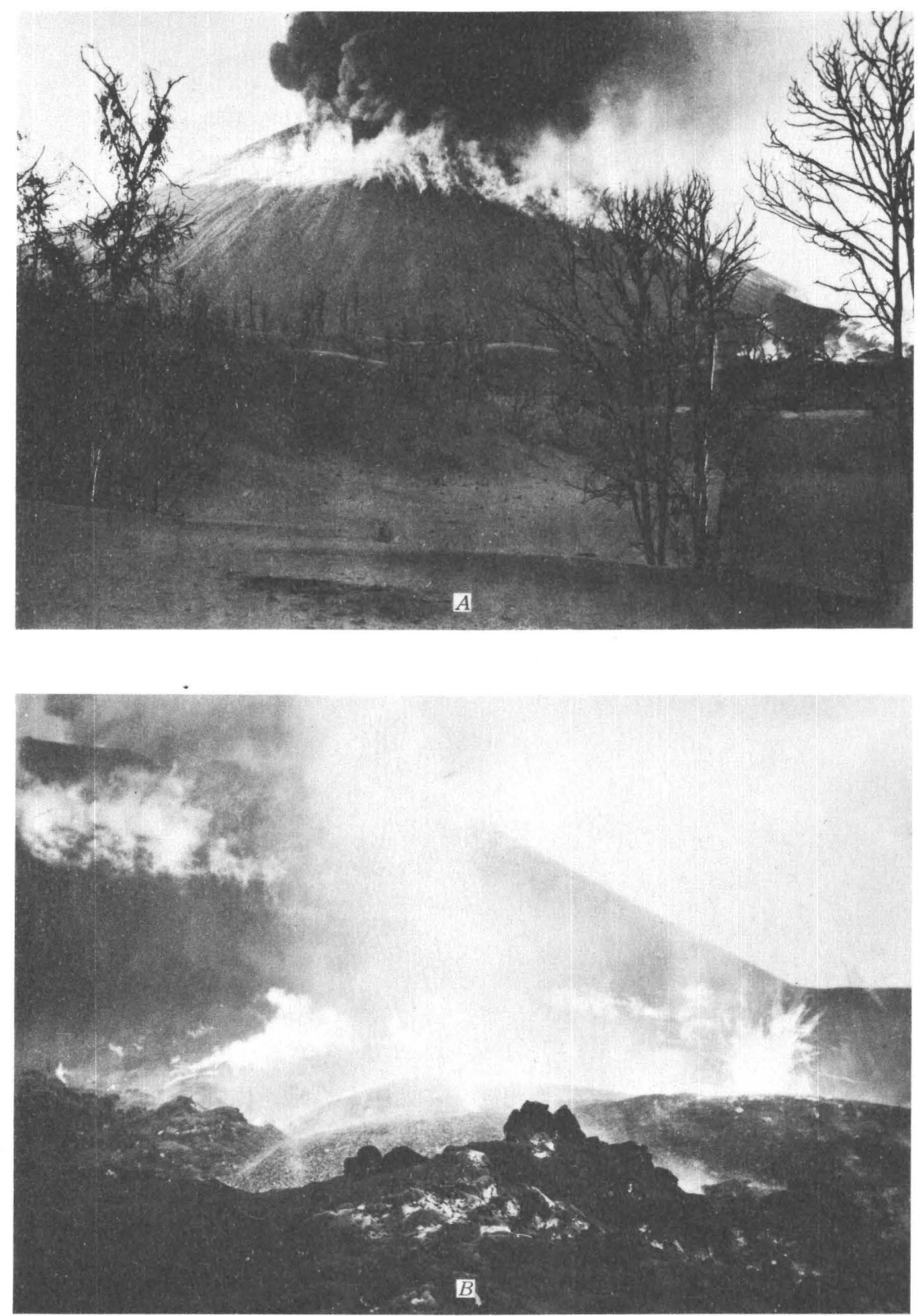

\section{STEAMING ASH IN UPPER LEVELS OF CONE AND OUTBREAK OF SAPICHU AT BASE OF MAIN CONE}

A.-October 19, 1943. Zone of steaming ash in upper levels of the cone. Such sharply defined haloes of steam were fairly common. Taken from the summit of Cerro de Jarátiro. Photograph by Arno Brehme.

B.-October 20, 1943. Outbreak of Sapichu viewed from the east. A series of vents extending from base of main cone to northeast broke out in the old Lagunita flow. Photograph by Lyn Storm. 

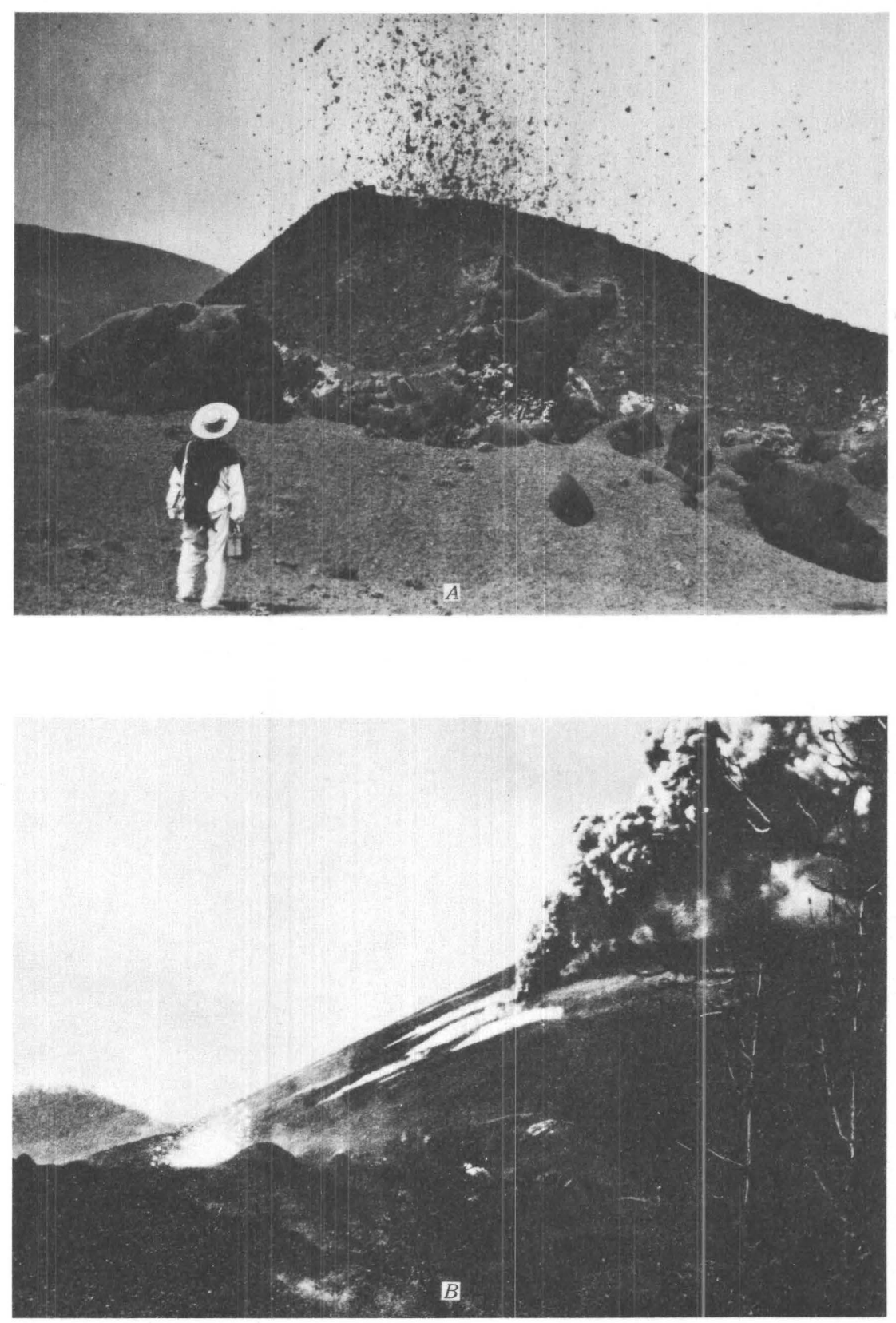

\section{SAPICHU}

A.-October 21, 1943. The new adventitious cone, Sapichu, at the base of Parícutin. A continuous fountain of viscous bombs without visible eruptive column. Taken from the east. Photograph by Lyn Storm.

B.-October 21,1943 . Eruptive chimney and steaming cracks on the north slope of Parícutin, and the new cone of Sapichu at the base of the cone. Taken from the northwest. Photograph with infrared film by Lyn Storm. 

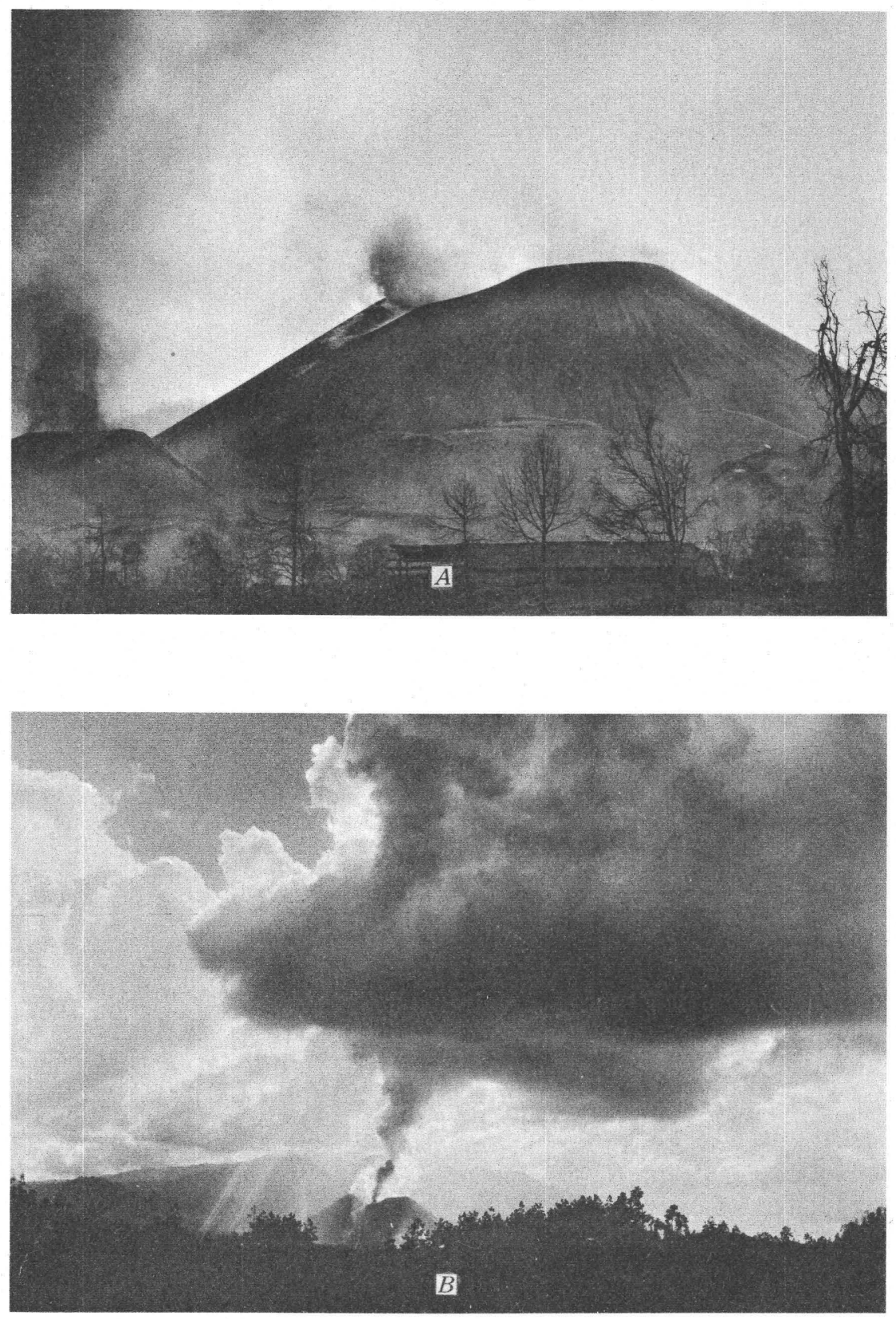

\section{SAPICHU ERUPTING}

A.- November 28, 1943. During eruption of Sapichu, activity in the Parícutin crater was reduced to a lazy emission of vapor. A depressed boggy swale extended from the summit toward Sapichu, and the north slope was crusted with salts. Photograph taken from Cerro de Jarátiro.

B.-December 6, 1943. The vaporous emission from Sapichu sometimes condensed as a huge cloud above the volcano. Cumulus clouds in background. Photograph taken from Angahuan. 

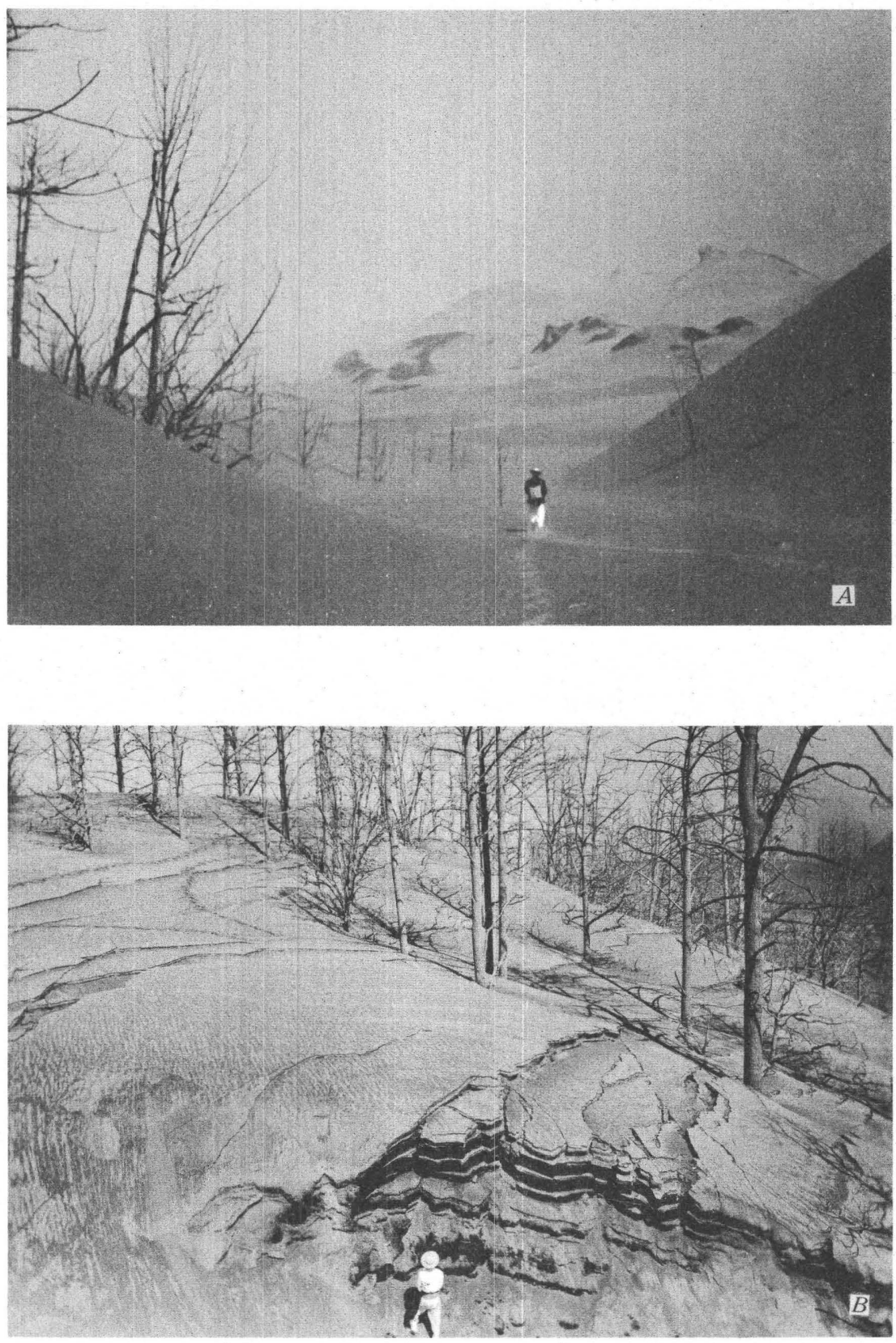

ASH-GOVERED HILLS AND FLOWS

A.-January 9, 1944. Lower slopes of Cerro de Canicjuata on the left; ashcovered Quitzocho ridge in the distance. Photograph taken from the southwest.

B.-January 8, 1944. Fissures and displacement in ash along a "tremor zone" at the foot of Mesa de Cocjarao, west of the cone. 

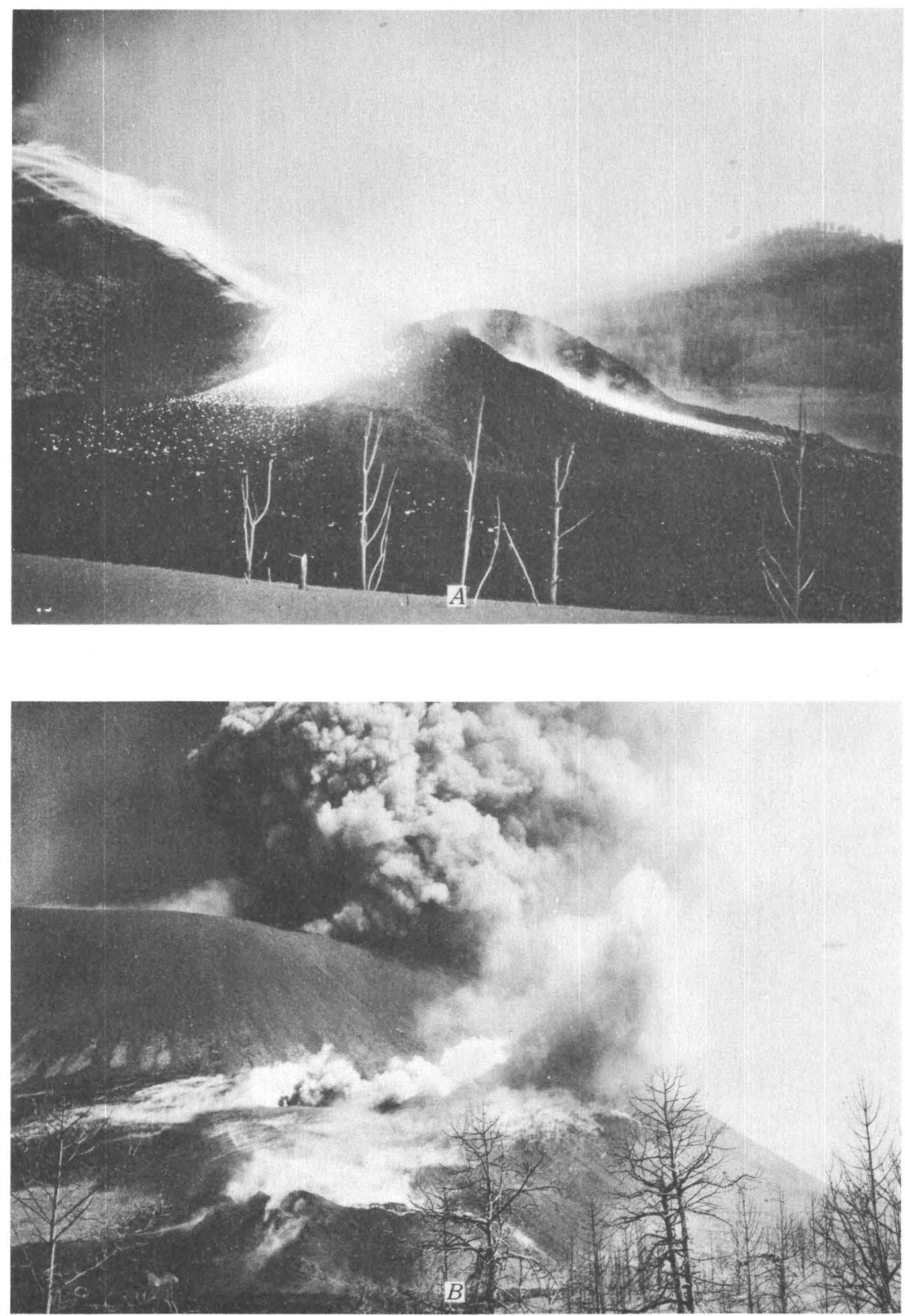

\section{TAQUÍ VENTS}

A.-January 8, 1944. First day of the Taquí lava flow. Three vents yielded a continuous flow of lava. Steaming lower slopes of the cone to the upper left; lower slopes of Cerro de Canicjuata in the foreground. The varying degrees of incandescence mark lava surges. Photograph taken from the northwest.

B.-January 9,1944 . Area of the Taquí vents, which are on the lower slope, an eruptive chimney upon an upper knoll. Taquí lava flow on the lower left; slopes of Mesa de Cocjarao lower right. 

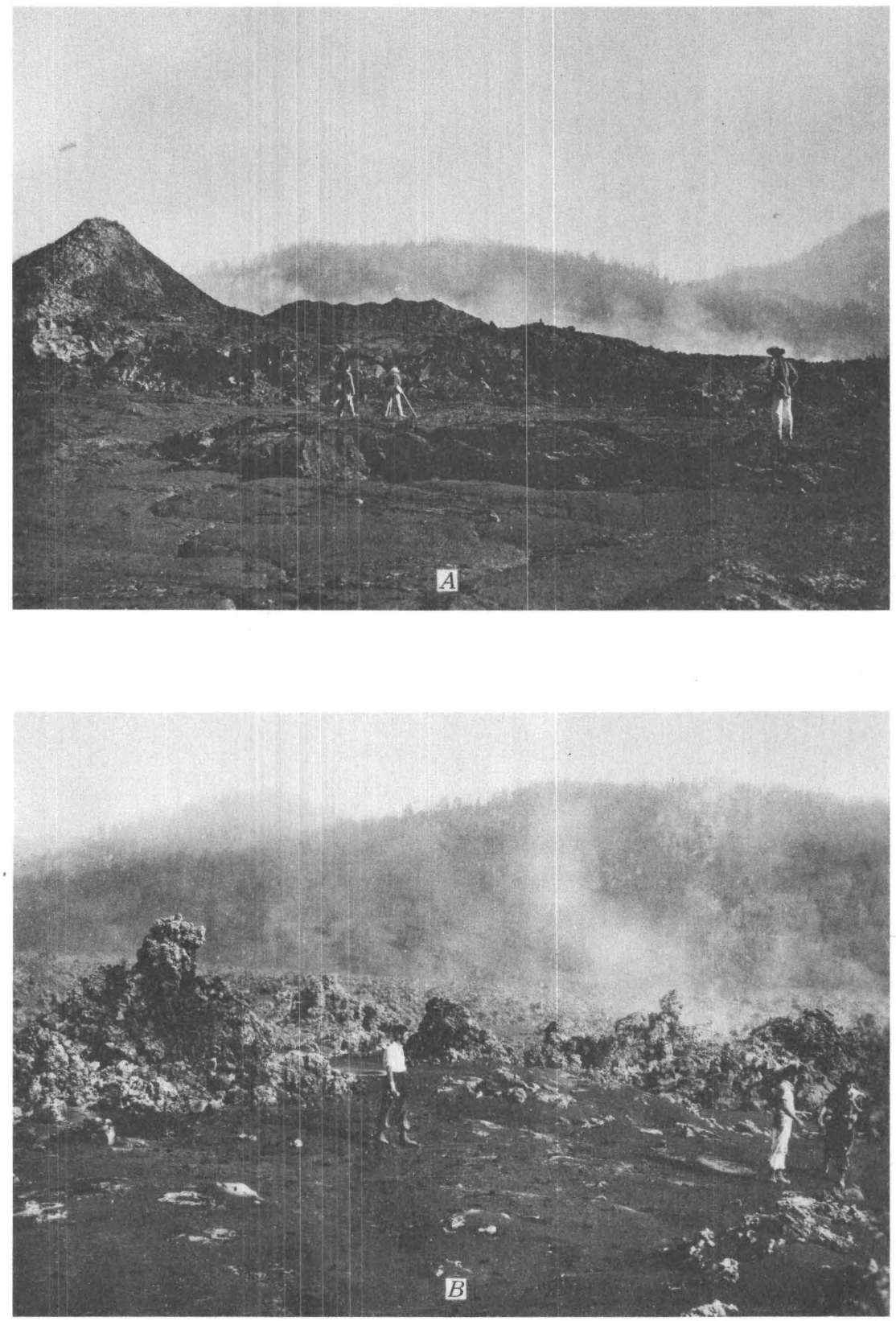

\section{MESA DE LOS HORNITOS}

A.-March 21, 1944. Area of the Taquí vents (now buried), now called Mesa de Los Hornitos. Pahoehoe lava from "volcancito" to the left. Photograph taken from the north.

B.-May 24, 1944. Surface of the Taquí lava flow showing the hornito fields. Abundant yellow and orange salts colored the area, Mesa de Los Hornitos. Photograph taken from the northeast. 

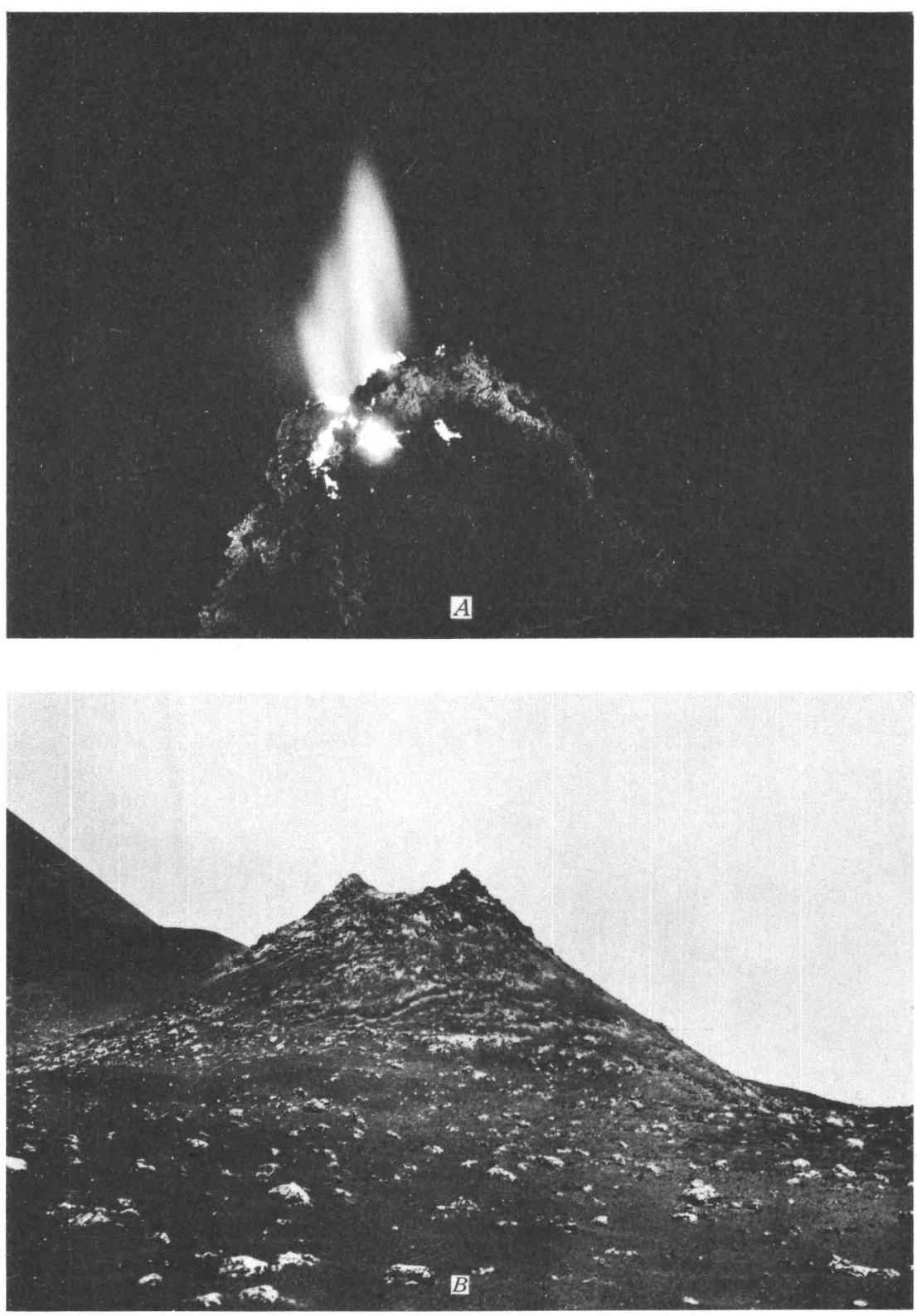

\section{A HORNITO AND A VOLCANCITO}

A.-March 22, 1944. Burning gases from the orifices of a hornito. These flames are pale blue and only visible at dusk and night. The vents are lined with fused lava.

B.- May 24, 1944. A volcancito on the surface of the Taquí lava flow. Such edifices eject small bombs and emit burning gases and bluish fumes from their summit vents. They are situated above the area of the Taquí vents and are due to a flow of gas-charged lava through cracks in the lava crust. Photograph by Ezequiel Ordóñez. 

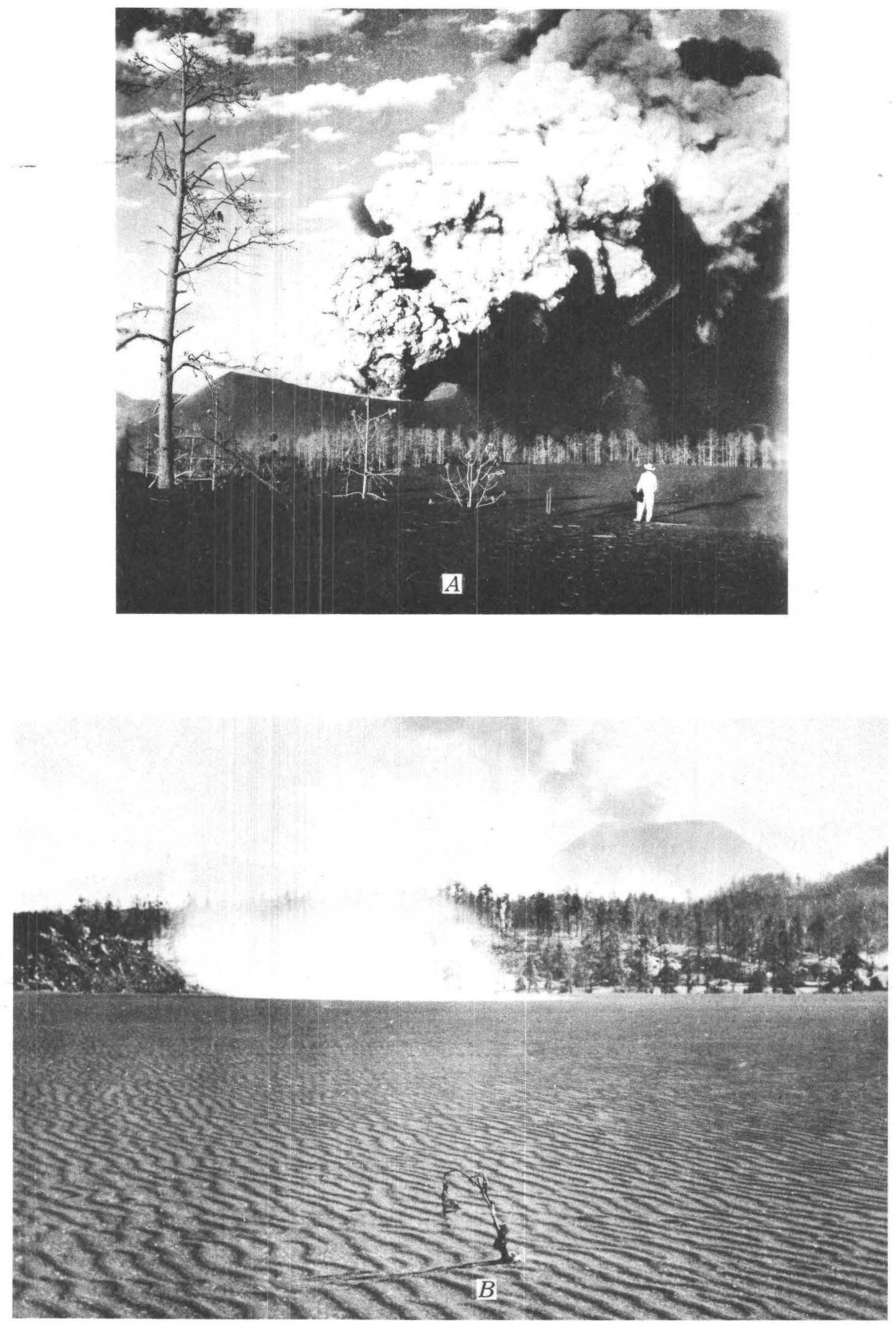

\section{PARÍCUTIN VOLCANO}

A.-March 22, 1944. Parícutin volcano from Mesa de Cocjarao. The lowered south rim is due to scouring by the eruptive column of the south crater vent. Eruptive column is pale buff and largely vaporous. Photograph taken from the southwest.

B.- March 1944. Parícutin volcano looking northeast from Las Cruces. Windblown ash in the foreground. Photograph by Arno Brehme. 

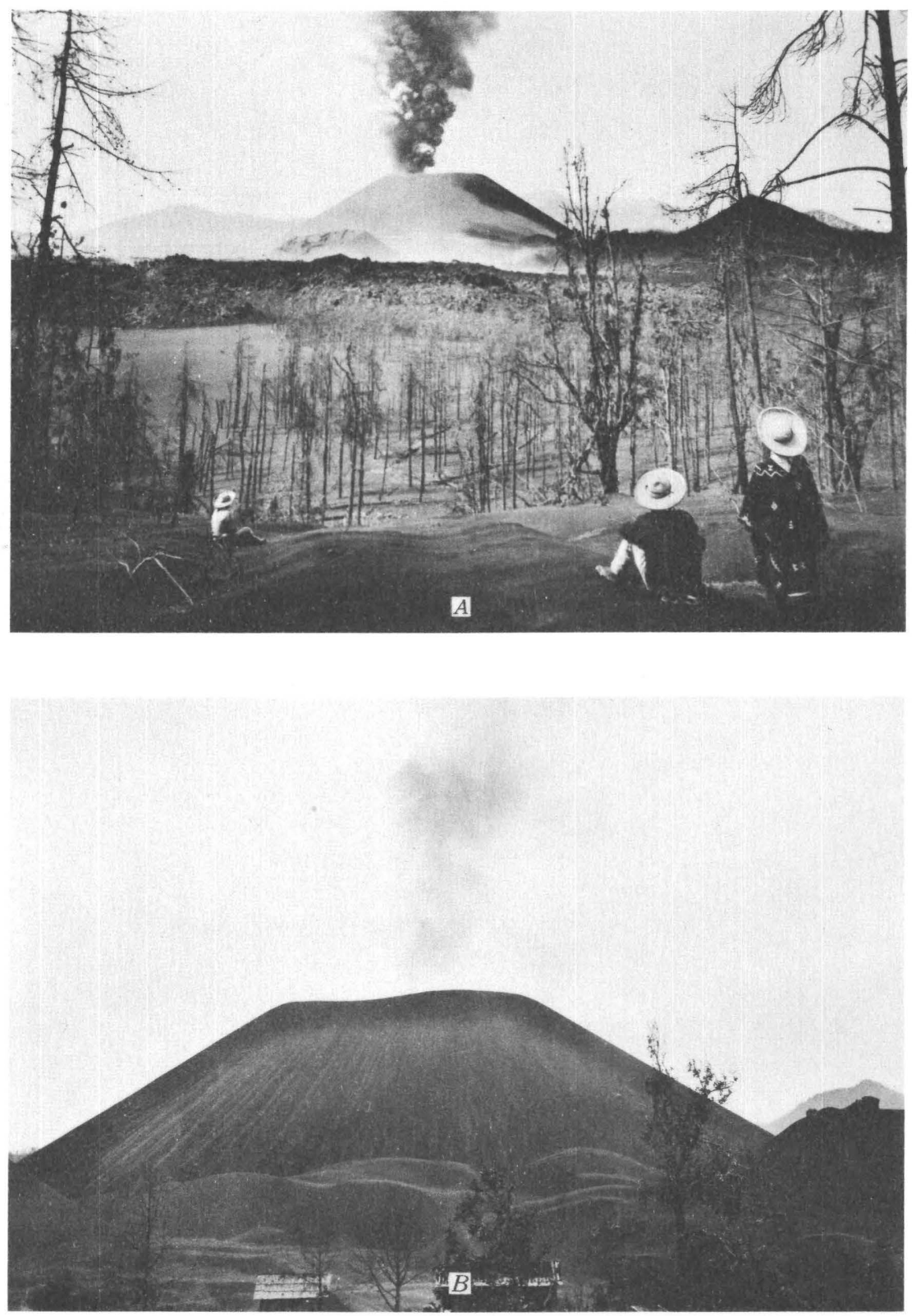

PARÍCUTIN VOLCANO FROM CERRO DE EQUIJUATA AND CERRO DE JARÂTIRO

A.- March 1944. Parícutin volcano from northeast at Cerro de Equijuata. Sapichu at the foot of main cone. Rugged lava of the flows of June in the middle distance. Photograph by Arno Brehme.

B.-May 27, 1944. Parícutin emitting sparse ash-vapors are also being emitted, but they cannot be seen. This type of activity is accompanied by an intermittent rolling rumble and fall of gritty ash. Photograph taken from Cerro de Jarátiro. 

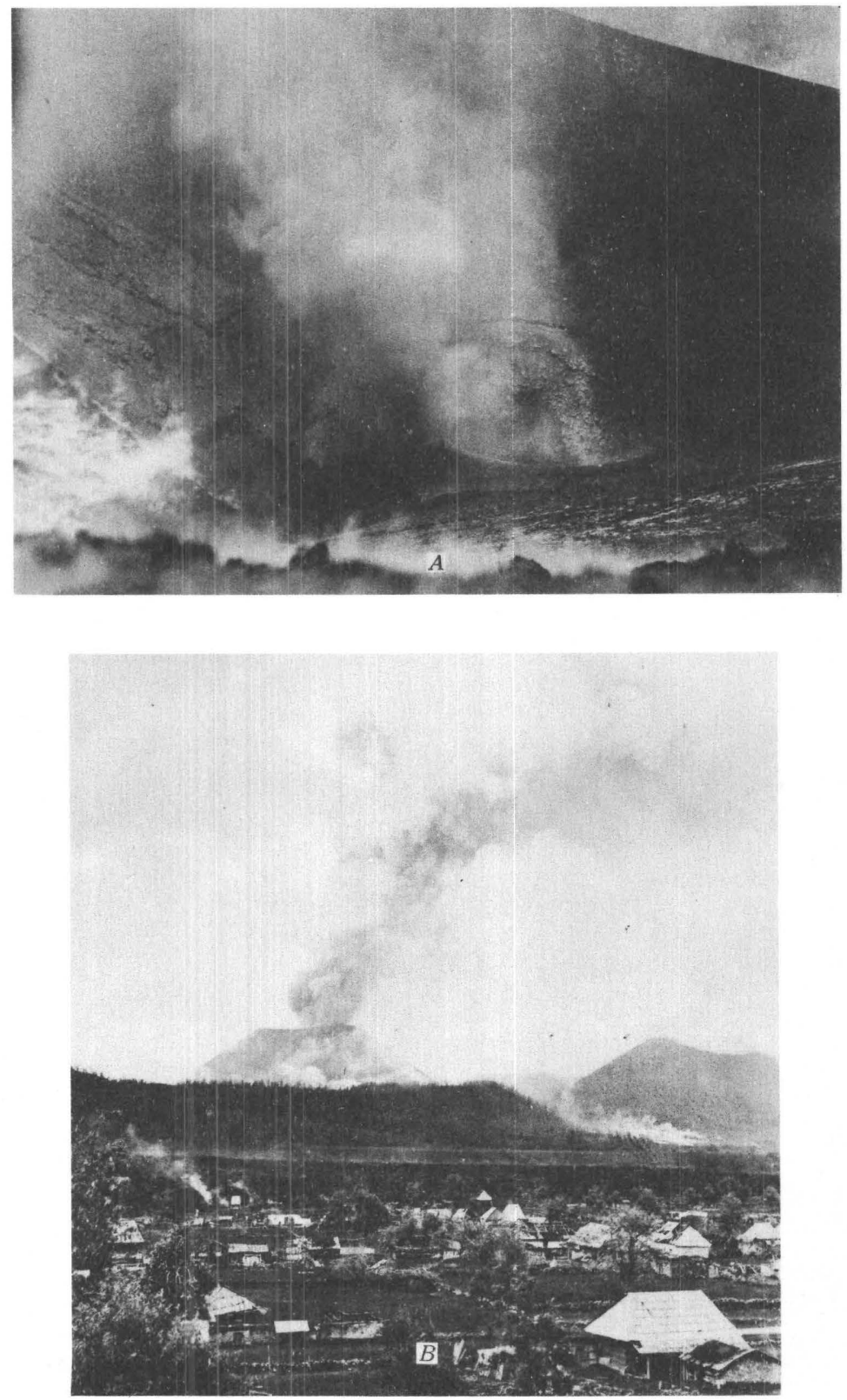

PARÍCUTIN VOLCANO: INTERIOR OF CRATER AND LONG RANGE VIEW

A.-May 25, 1944. The interior of the crater. A small vent in the bottom emitted a small column of brownish dust; a saucer-shaped depression in the lower south flank jets invisible vapors with a grating roar. Eruptive activity on this day very much reduced.

B.--June 17, 1944. San Juan Parangaricutiro in the foreground, the Parangaricutiro lava tongue beyond; Parícutin lava flow (middle) steaming from recent rain. Cerro de Canicjuata on right; Cerro de Jarátiro on left. Photograph taken from Cerro de La Capilla, north. 

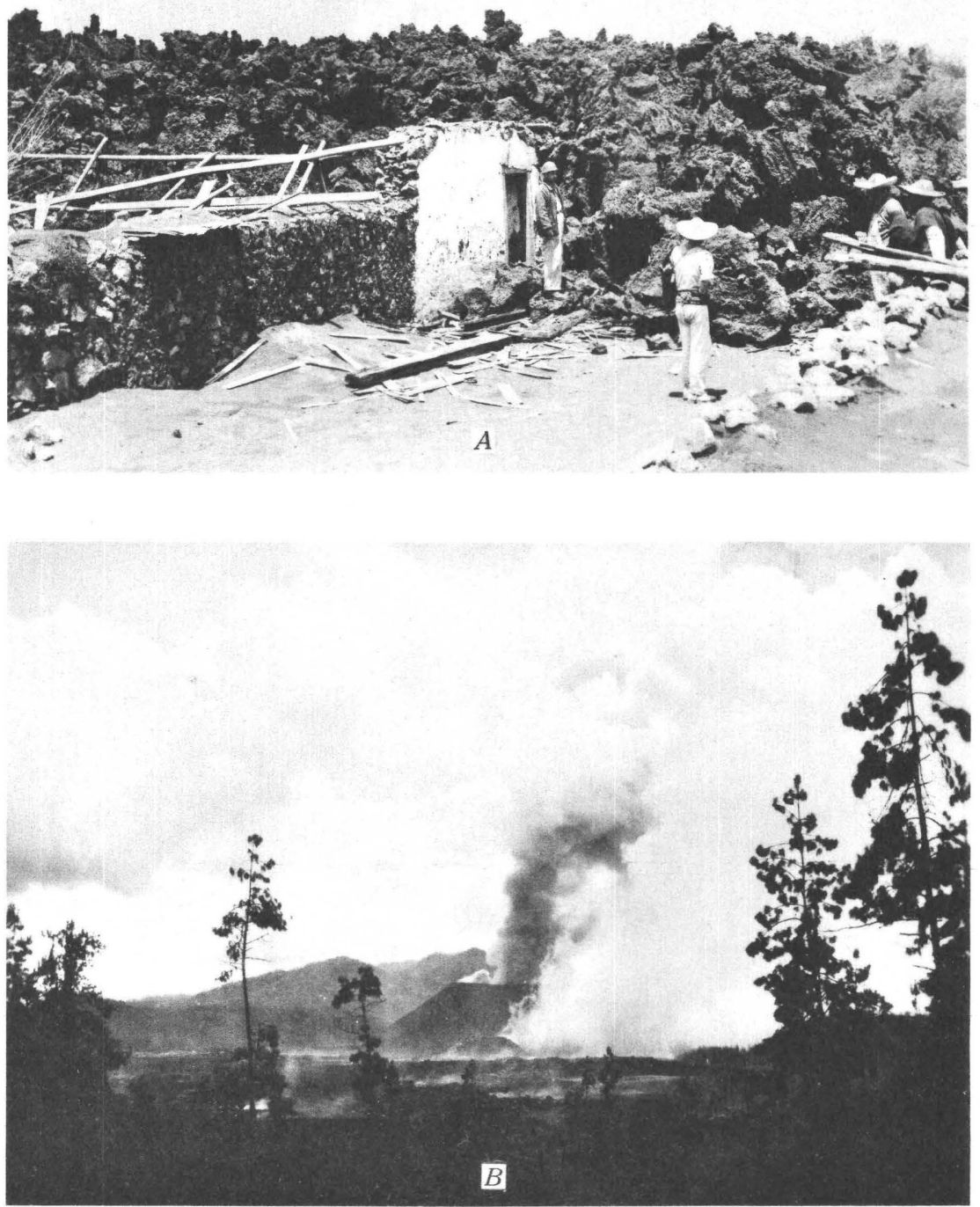

PARANGARICUTIRO TONGUE AND PARÍCUTIN VOLCANO

A.-June 20, 1944. Parangaricutiro lava tongue advancing slowly through the town.

B.-August 14, 1944. Fog drifting in from the west is halted by the rising eruptive column of Parícutin. Photograph taken from Cerro de Nureto, northeast. 

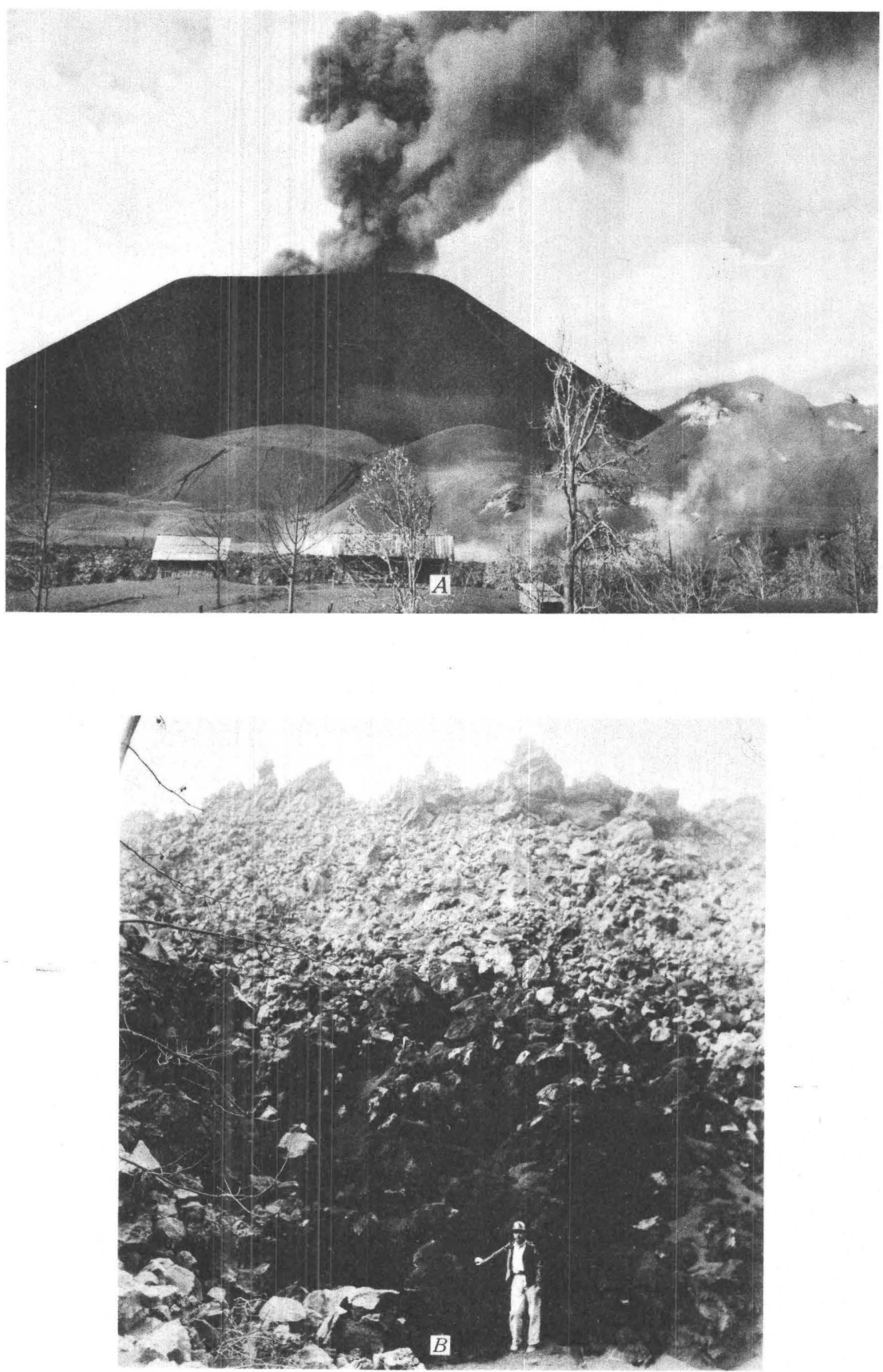

\section{ERUPTIVE COLUMN AND BLOCK LAVA FRONT}

A.--August 16, 1944. Characteristic eruptive column during this period. Quitzocho ridge to the right. Campamento tongue of the Taquí flow behind the houses. Photograph taken from Cerro de Jarátiro.

B.-July 31, 1944. Block lava front from a small flow from Quitzocho ridge. 

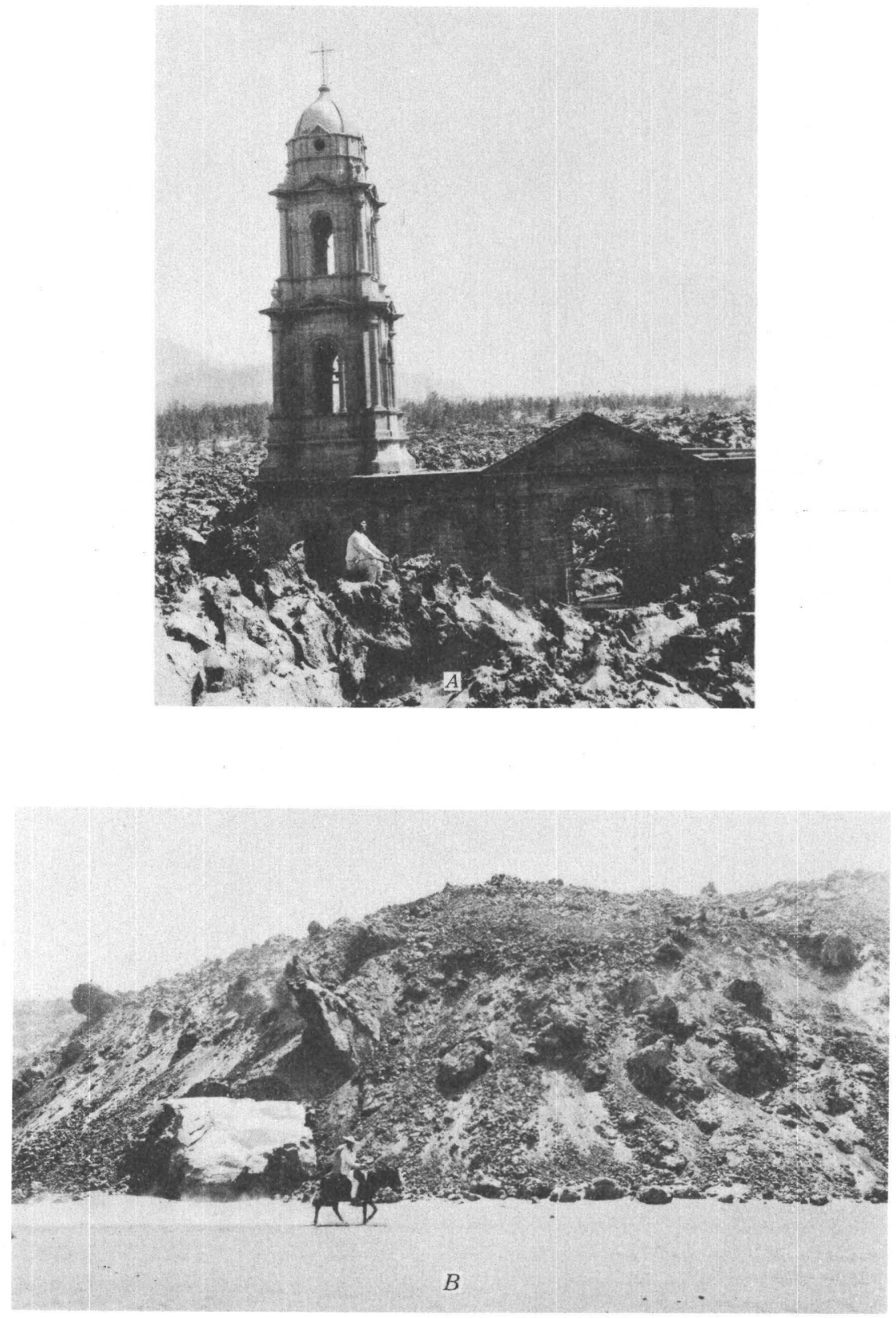

\section{PARANGARICUTIRO TONGUE AND SAPICHU FLOW}

A.-January 25, 1945. The tower of the San Juan Parangaricutiro church above the lava of the Parangaricutiro tongue of the Taquí flows. Behind the tower lies the engulfed town.

B.--March 23, 1944. The rubble front of the Sapichu lava flow at the San Juan Parangaricutiro-Uruapan road. A common type of lava at Parícutin. 

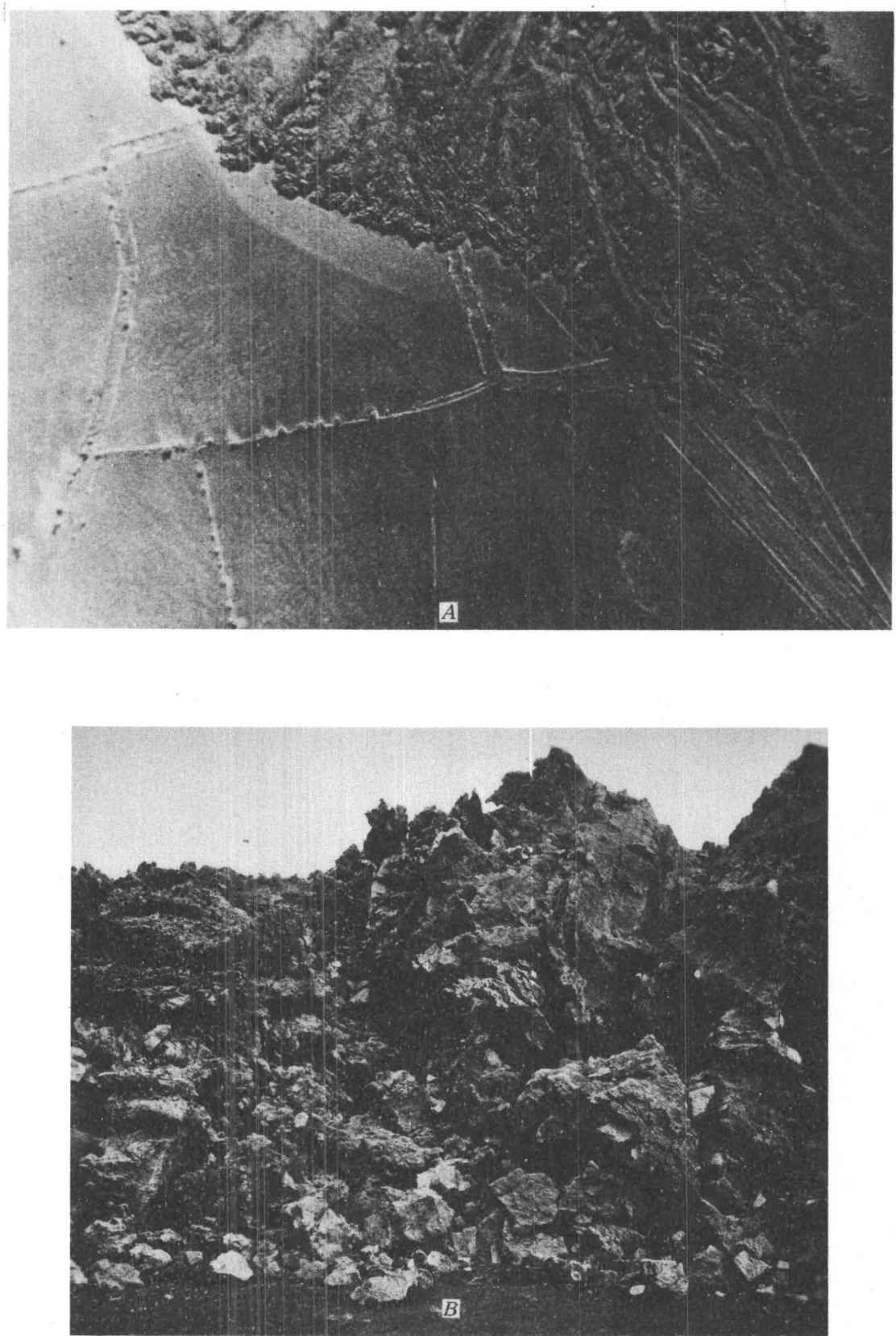

\section{PARANGARICUTIRO TONGUE: AERIAL AND GROUND VIEWS}

A.-December 2, 1944. Aerial view, end of the Parangaricutiro lava flow at Llano de Huirambosta, showing the individual lava emissions from the top of the lava flow, a feature peculiar to this tongue. Photograph by Otto O. Fisher. B.--July 1, 1944. Structure of the Parangaricutiro tongue of the Taquí flows. This torn structure is peculiar to this tongue. 

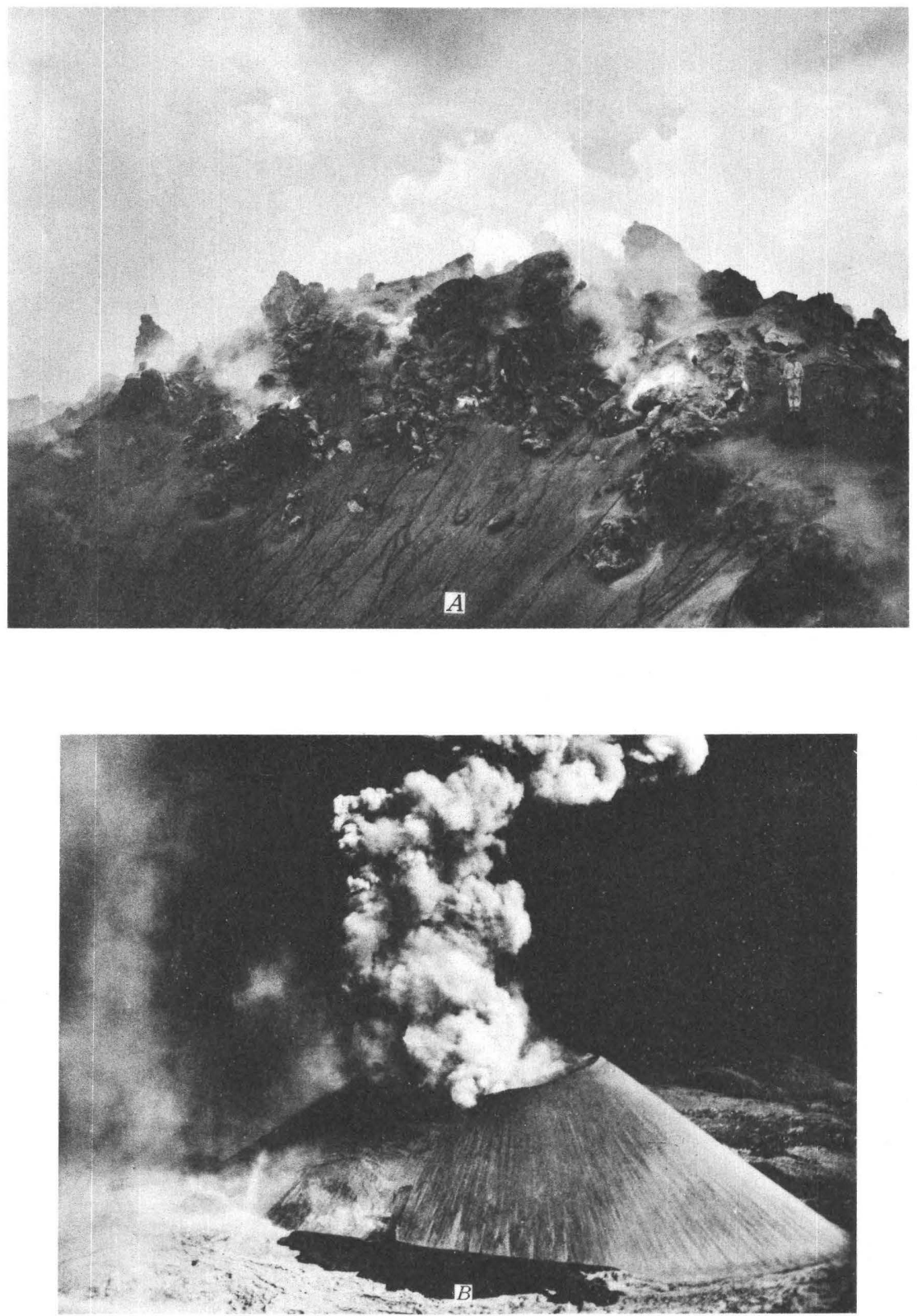

\section{SAPICHU AND TAQUÍ FLOWS}

A.-August 17, 1944. Fumaroles in the Sapichu flow, with deposits of yellow and orange iron and aluminum chlorides.

B.-Mid-November 1944. The Ahuán break and beginning of the Ahuán flows, viewed from the south. In the foreground lavas of the Taqui flows. Fresh lava photographs black. Aerial photograph by Frank Zierer. 

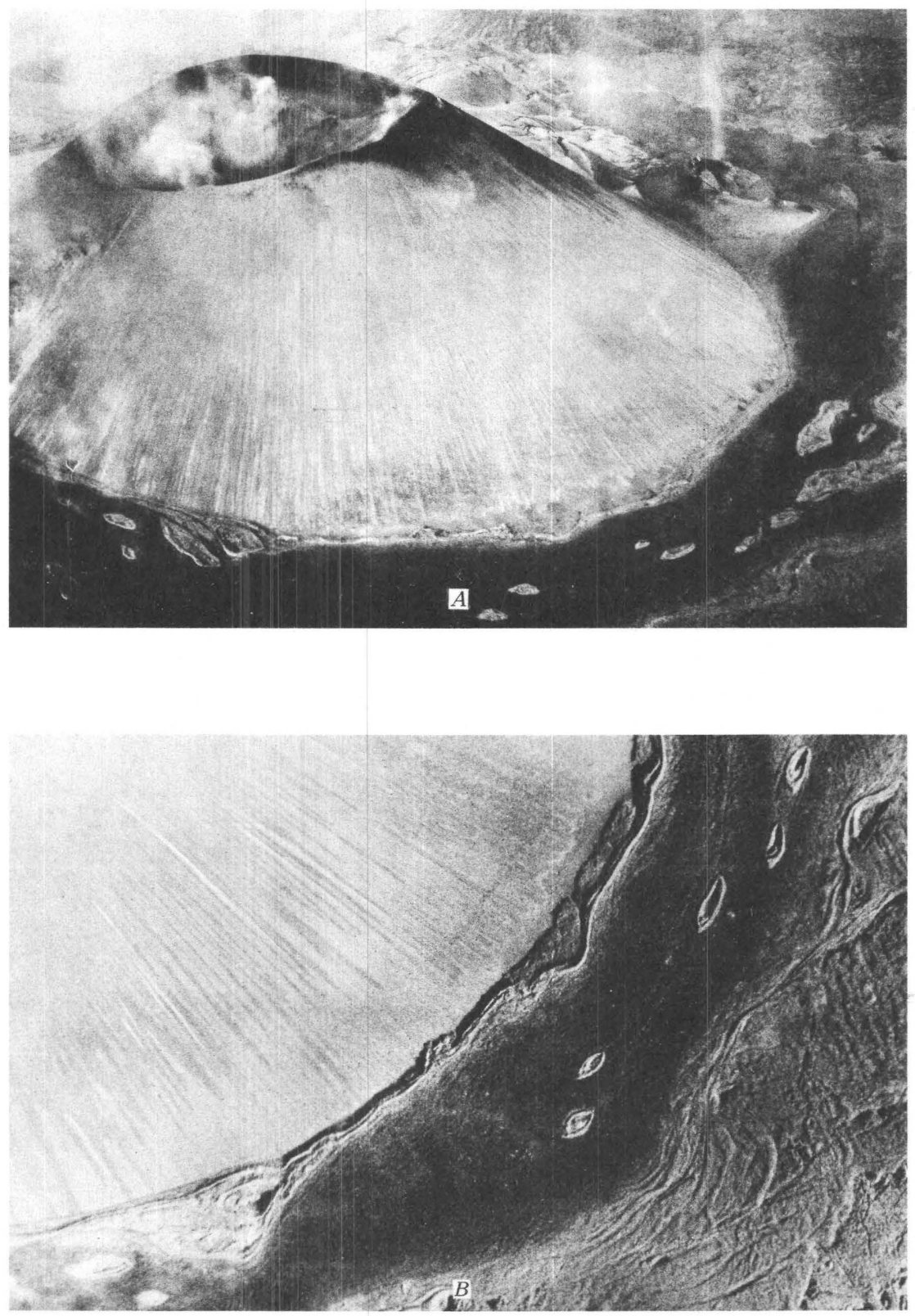

\section{AHUÁN FLOW}

A.- November 29,1944 . The cone and crater and the Ahuán flow viewed from the south. Sapichu at opposite base of the cone. Aerial photograph by Otto O. Fisher.

B.-December 2, 1944. Details of the Ahuán flow showing kipukas of Taquí lava, clinker dikes of the flow along the base of the cone, and overflow of the lava to the right. Photograph by Otto O. Fisher. 

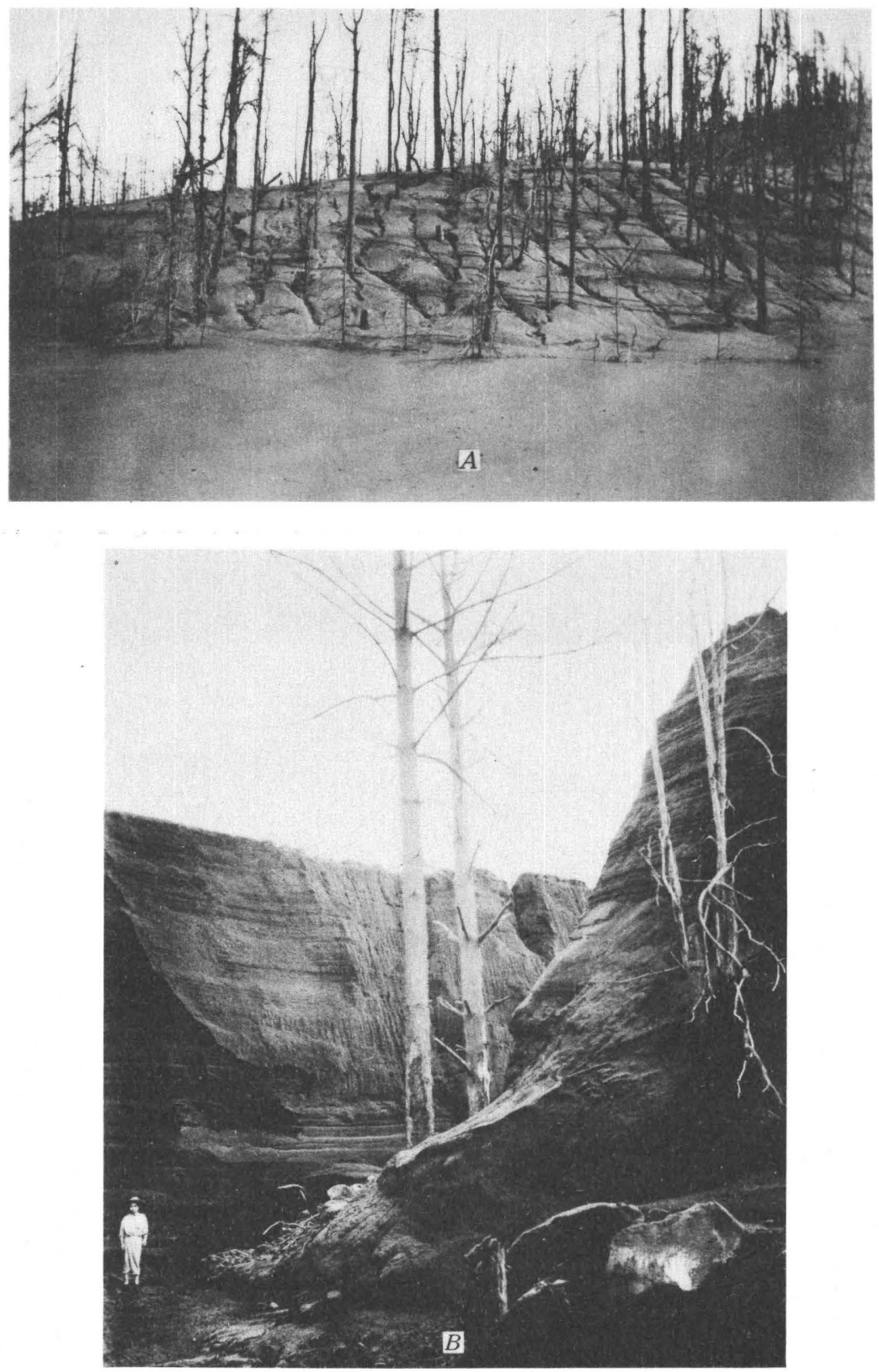

TYPICAL EROSION IN ASH

A.-January 25, 1945. Typical erosion gullies in the ash. A mat of pine needles from the dead trees frequently inhibits erosion. Photograph by Ezequiel Ordóñez.

B.-Erosion arroyo in the ash at the foot of Cerro de Canicjuata, the result of a single storm. Erosion has taken place several feet below the old land surface. 

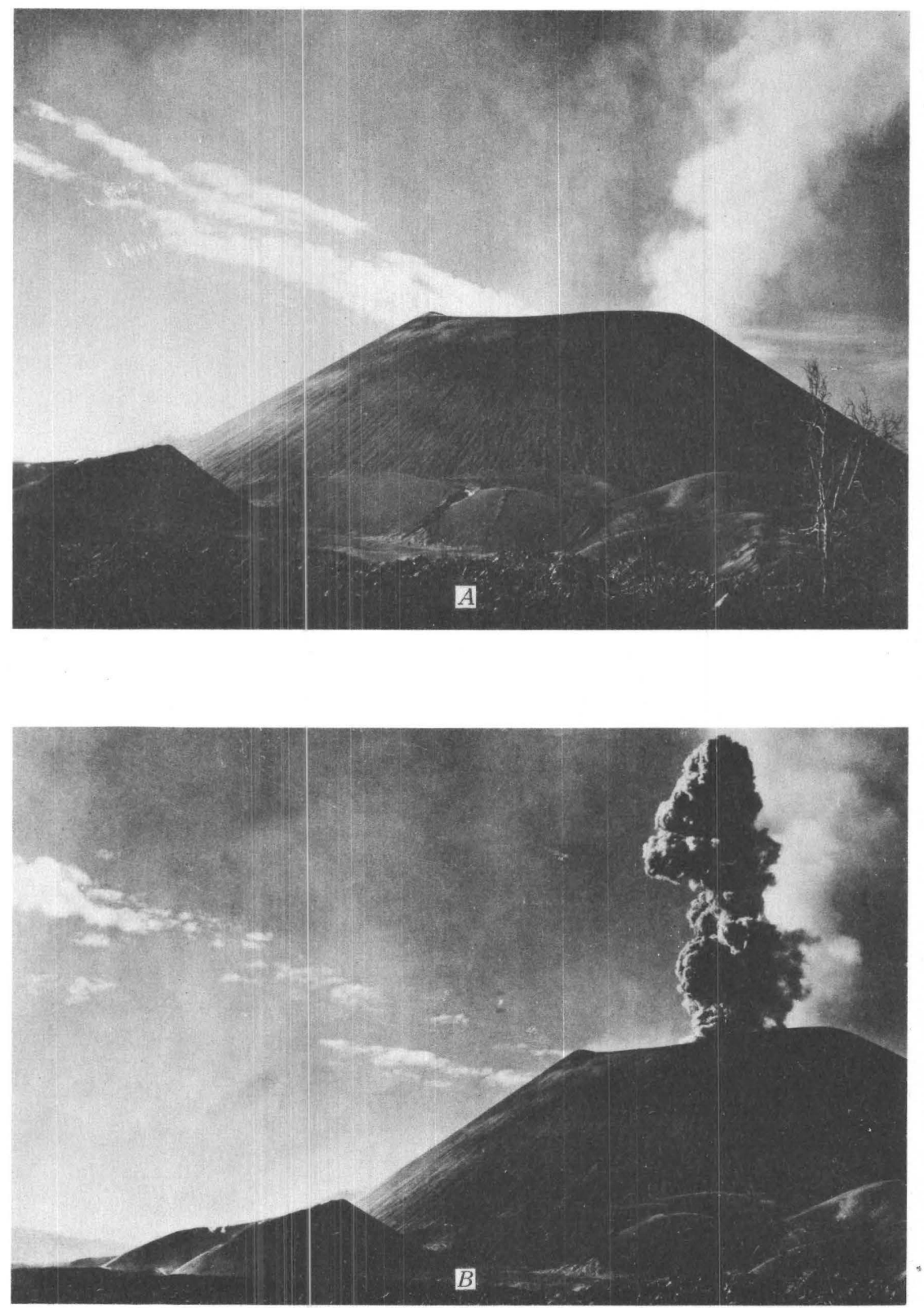

\section{CRATER EMISSIONS}

A.-December 4, 1944. Weak vaporous crater emission with a little gritty ash. This type of explosion is accompanied by a rolling rumble. Photograph taken from Cerro de Jarátiro.

B.-December 6,1944 . One of the intermittent crater explosions that were followed by a period of quiet. Photograph taken from Cerro de Jarátiro. 

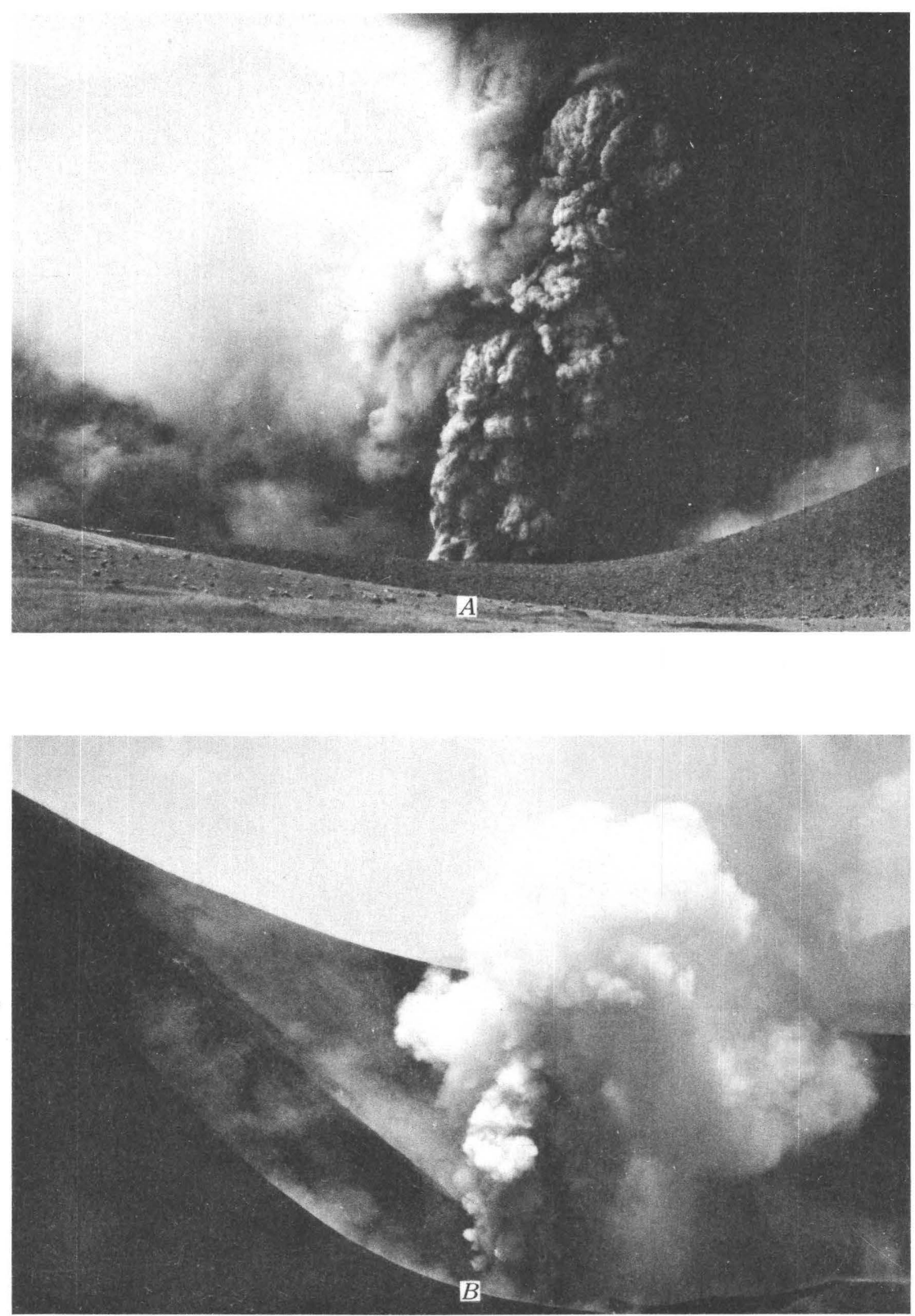

\section{INTERIOR OF THE CRATER}

A.-January 23, 1945. Interior of the crater, with one eruptive vent and a medium-sized eruptive column charged with ash.

B.-May 27, 1945 . Interior of crater with two vents; the north vent emits a continuous column of white vapors; the south vent, beyond the low medial ridge, erupts at irregular intervals. 

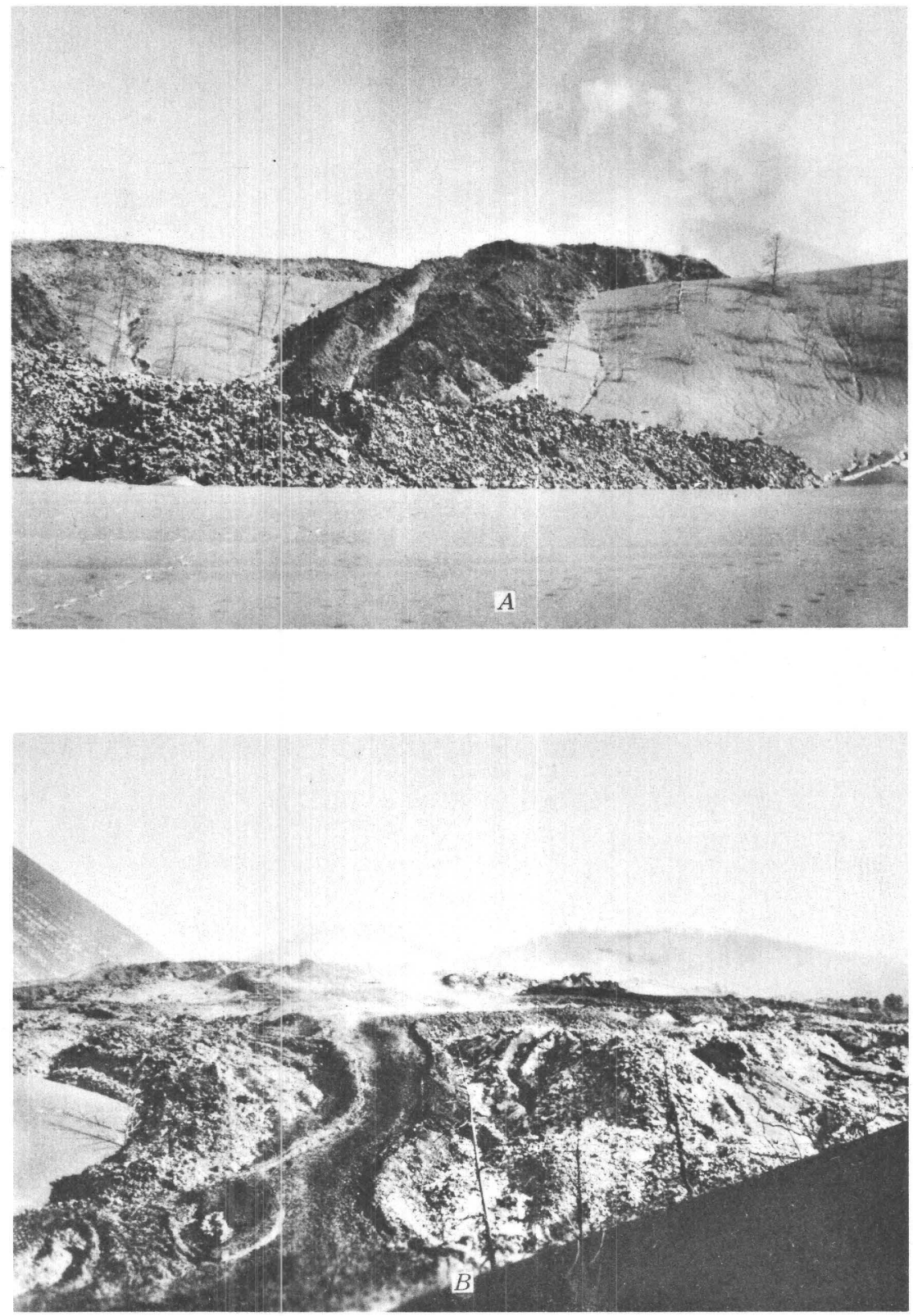

TAQUÍ FLOWS POURING OVER A RIDGE

A.-February 18, 1945. One of the Taquí flows pouring over a ridge. The fluid center of the flow has left a deep trench, but a second lava surge begins to fill it. Taken from the north. Photograph by Ezequiel Ordóñez.

B.-July 1945. Same area viewed from the north 5 months later, showing various flows. Mesa de Los Hornitos above. Photograph by Ezequiel Ordóñez. 


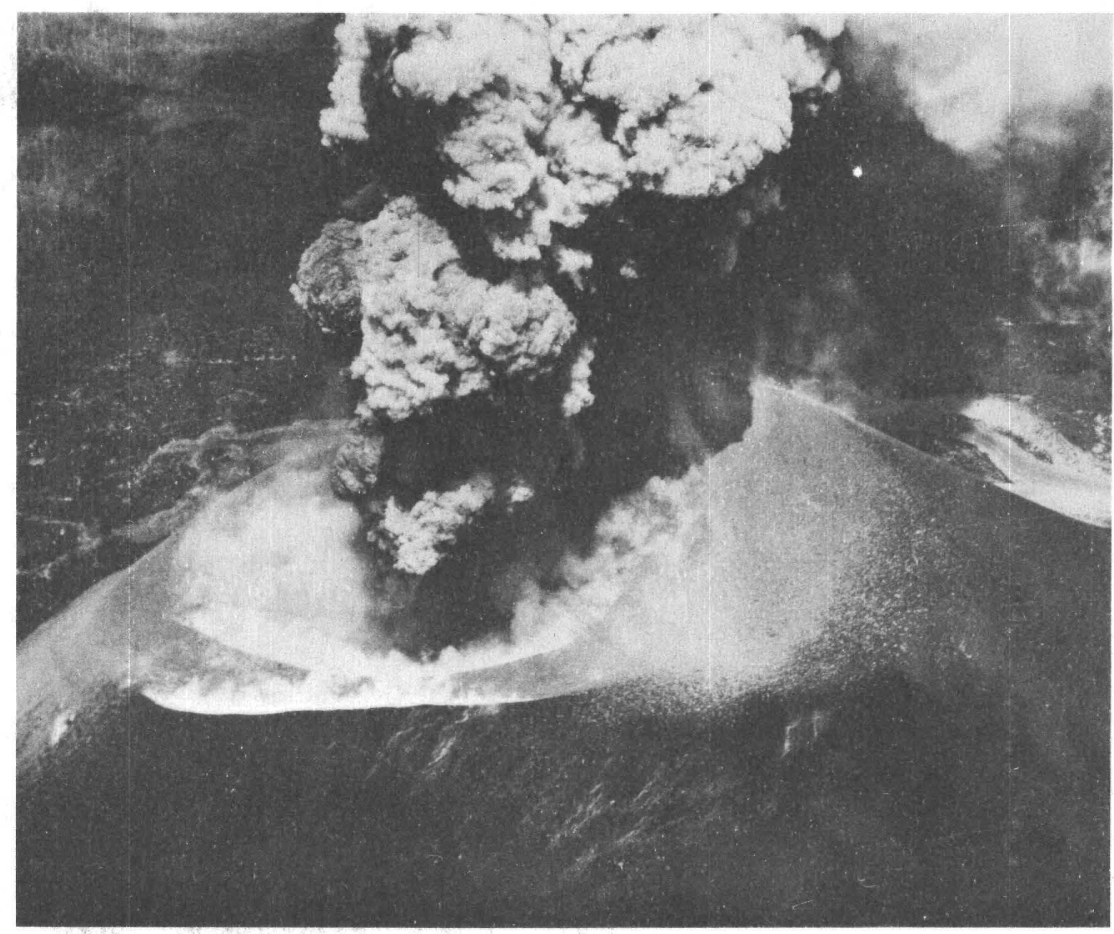

\section{INTERIOR OF CRATER}

July 31,1945 . Interior of crater with one active vent. The bench is a remnant of a higher floor of the crater. Aerial photograph taken from the south. 